Metodologia para integração de dados genômicos, transcriptômicos e epigenéticos de câncer de pênis

Fabio Albuquerque Marchi

TESE APRESENTADA

$\mathrm{AO}$

Programa Interunidades EM BioINFormática

DA

UNIVERSIDADE DE SÃo PAUlo

PARA

OBTENÇÃO DO TÍTULO

$\mathrm{DE}$

DOUTOR EM BIOINFORMÁTICA

Programa: Programa Interunidades de Pós-Graduação em Bioinformática Orientador: Profa. Dr. Silvia Regina Rogatto

Durante o desenvolvimento desse trabalho o autor foi bolsista CAPES

São Paulo, 28 janeiro de 2014 


\section{Metodologia para integração de dados genômicos, transcriptômicos e epigenéticos de câncer de pênis}

Esta versão da tese contém as correções e alterações sugeridas pela Comissão Julgadora durante a defesa da versão original do trabalho, realizada em 14/04/2014. Uma cópia da versão original está disponível no Instituto de Matemática e Estatística da Universidade de São Paulo.

Comissão Julgadora:

- Profa. Dra. Silvia Regina Rogatto (orientadora) - AC Camargo Cancer Center

- Prof. Dr. David Corrêa Martins Júnior - UFABC

- Prof. Dr. Eduardo Moraes Rego Reis - IQ-USP

- Prof. Dr. Ronaldo Fumio Hashimoto - IME-USP

- Prof. Patricia Pintor dos Reis - UNESP-Botucatu 
"Há ocasiões em que é mil vezes preferível fazer de menos que fazer de mais, entrega-se o assunto ao governamento da sensibilidade, ela, melhor que a inteligência racional, saberá proceder segundo o que mais convenha à perfeiçâo dos instantes seguintes." 


\section{Agradecimentos}

À minha família Romilda (avó), Maristela (mãe) e André (irmão) por todo o carinho, respeito e incentivo durante esses anos. Família sempre em primeiro lugar.

À minha orientadora, Dra Silvia Regina Rogatto, pelos últimos 10 anos contribuindo para a minha formação, por ter me aceito como aluno e acreditado na minha capacidade. Agradeço por todo o apoio que sempre me deu nos momentos mais difíceis, toda a confiança, além de suas ótimas idéias, sempre fundamentais para o desenvolvimento deste e de outros projetos. Obrigado Silvia!

Aos amigos de laboratório Priscila Cirilo, Cássia, Fernanda Bertonha, Sara, Luciana, Renata Bueno, Hellen, Ariane, Livia, Miriam, Fabíola, Francine, Eliane, Fernanda Fortes, Renata Canevari, Mateus, Graziela, Rodrigo, André, Juan, Marco, Carol, Tatiane, Maísa, Débora, Júlia, Andréia e Priscila por todas as risadas, aprendizado e colaborações durante esses anos.

Ao Dr Igor Jurisica e sua equipe por terem me recebido no OICR (Ontario Institute for Cancer Research) e disponibilizado toda a estrutura para o desenvolvimento dos projetos.

Ao Dr Roberto M Cesar Jr por ter me introduzido no grupo da bioinformática e por suas indicações.

Aos colaboradores Dra. Helena Brentani e Dr. David C Martins Jr por toda disponibilidade durante o desenvolvimento desse projeto, por toda paciência, suas ótimas idéias e esforço em arrumarem um horário para reuniões e se deslocarem até o IME. Muito Obrigado David e Helena!

Aos membros da CPG-Bioinfo pela oportunidade de aprendizado durante a organização de três cursos de verão em bioinformática.

À Patrícia Martorelli por toda ajuda, disponibilidade e paciência desde sempre. Obrigado Patrícia!

Aos amigos de Botucatu e aqueles que já não estão mais na cidade, que mesmo com toda distância permanecem os grandes amigos de sempre.

À CAPES pelo apoio financeiro que tornou possível o desenvolvimento desse projeto.

Ao AC Camargo Cancer Center por ter me aberto as portas para desenvolver o meu projeto.

Aos doutores Fernando Augusto Soares, José Vassallo, Gustavo Cardoso Guimarães e Isabela Werneck da Cunha por todo auxílio para realização desse projeto.

Aos membros da banca por terem aceitado participar e por sua disponibilidade.

À Lisley, que me apoiou e me deu força em momentos difíceis, sempre com seu lado positivo cativante. 


\section{Resumo}

MARCHI, F. A. Metodologia para integração de dados genômicos, transcriptômicos e epigenéticos de câncer de pênis. 2014. Tese (Doutorado) - Instituto de Matemática e Estatística, Universidade de São Paulo, São Paulo, 2014.

O desenvolvimento de metodologias sobre integração de dados na área de biologia de sistemas é de grande importância devido ao aumento contínuo de dados resultantes de análises globais que são depositados em bancos de dados públicos. Poucas metodologias e ferramentas de bioinformática levam em consideração a diferenciação entre drivers e passengers, fundamental para a identificação de genes importantes para o desenvolvimento e progressão tumoral. Os perfis de expressão gênica têm possibilitado a identificação de assinaturas genéticas em uma grande variedade de tumores humanos. Além disso, as alterações epigenéticas, como a expressão de microRNAs (miRNA) e a metilação do DNA, também contribuem para o desenvolvimento de diversos tipos de doenças. Entretanto, a grande maioria destes estudos não mostra integração dos resultados obtidos pelas diferentes estratégias utilizadas, o que teria maior impacto na identificação de drivers moleculares. Neste estudo foi realizada a integração de quatro níveis de alterações em 31 amostras de câncer de pênis (CaPe): alteração do número de cópias do DNA, metilação de ilhas CpGs, expressão de miRNAs e expressão de transcritos codificadores. O conhecimento das alterações genéticas e epigenéticas relacionadas ao desenvolvimento de câncer de pênis é bastante limitado, devido principalmente a sua rara incidência. Uma parcela significativa dos casos de CaPe tem sido associada com a infecção pelo Papilomavírus Humano (HPV). A metodologia para integração de dados foi aplicada utilizando duas abordagens: (1) estudo das alterações em câncer de pênis (tumor e normal) independente da infecção pelo HPV e (2) estudo das alterações relacionadas à infecção pelo HPV. A análise foi dividida em duas etapas, com a seleção de genes alvos específicos da doença e inferência de módulos a partir desses alvos. Destacam-se na metodologia a seleção de genes candidatos a driver utilizando a atribuição de pesos para cada alteração seguindo critérios pré-determinados, e.g. se o gene estava presente em uma região rara, após classificação pelo DGV (Database of Genomic Variants) e a utilização desses genes como alvos para identificação das possíveis relações entre eles e os módulos. Também foi realizada a adaptação da metodologia de redes em módulos, com a inclusão de genes passengers e interação proteína-proteína (PPI) como um critério para seleção dos módulos. Essa análise se mostrou eficaz na identificação de módulos gênicos bem relacionados com os drivers, resultando na escolha de vias biológicas potencialmente responsáveis pelo desenvolvimento do tumor. Os genes identificados após a comparação entre amostras tumorais e normais (SOX17, TWIST1, CAV1, PPARG, FLI1 e TNFSF10) e no estudo entre amostras positivas e negativas para infecção pelo HPV ( $P C N A, S O X 14$ e $R F C 4$ ) foram validados in situ por técnicas independentes. Para validação in silico das alterações encontradas na metodologia de integração de dados e para validação da metodologia de redes em módulos foram utilizadas 255 amostras de glioblastoma multiforme obtidas no banco de dados TCGA (The Cancer Genome Atlas). Foram identificadas vias biológicas importantes relacionadas ao processo tumoral, como regulação do crescimento celular (GO:0001558, $p=6,2 \times 10^{-3}$ ), homeostase (GO:0048872, $p=8,2 \times 10^{-3}$ ) e regulação da 
transcrição (GO:0003700, $p=8,9 \times 10^{-4}$ ). Também foi realizada uma meta-análise utilizando amostras do TCGA, que encontrou um perfil similar de expressão para os genes $C A V 1, D L C 1$, FLI1, MSX1, NRN1, PML, PPARG e SOX17 (T vs N) e PCNA e RFC4 (HPV+vs HPV-). Para o nosso conhecimento, esse é o primeiro estudo em CaPe utilizando análise integrada de quatro níveis de alteração. Além disso, foram encontradas alterações não randômicas capazes de modificar transcritos específicos e contribuir para o conhecimento da patobiologia dos tumores de pênis.

Palavras-chave: Integração, câncer, HPV, driver. 


\section{Abstract}

MARCHI, F. A. Integrative methodology in penile carcinomas. 2014. PhD thesis - Interinstitutional Grad Program on Bioinformatics - University of Sao Paulo.

Methodologies for data integration in systems biology area have great importance due to continuous increase of public data resulting from large-scale analysis, which are deposited in public databases. Few methodologies and bioinformatics tools take into consideration the differentiation between drivers and passengers, fundamental for the identification of important genes for tumor development and progression. The gene expression profiles have allowed the identification of genetic signatures in a wide variety of human tumors. In addition, epigenetic changes, such as the expression of microRNA (miRNA) and DNA methylation, also contribute to the development of a veriety of diseases. However, most of these studies did not show integration of results obtained by different strategies used, which would have increased impact to identify molecular drivers. This study provides a methodology for integration of four levels of changes in 31 samples of penile cancer (PeCa): copy number alterations, DNA methylation of CpG islands, miRNA expression and gene expression of coding transcripts. Knowledge about genetic and epigenetic changes related to the development of penile cancer is very limited, mainly due to its rare incidence. A significant portion of PeCa samples has been associated with infection by Human papillomavirus (HPV). The methodology for integrative data was applied using two approaches: (1) the study considering alterations in penile carcinoma (tumor and normal), independent of HPV infection and (2) the study considering alteration related to HPV infection in PeCa. In each study, the methodology was divided into two stages, with the selection of target genes and the inference of disease specific modules from these targets. It is highlighted in the methodology the selection of candidate genes using the driver assigning weights to each change following predetermined criteria, e.g if the gene was present in a rare region after classification using the DGV database (Database of Genomic Variants) and the use of these genes as seeds for identification of possible relationships between them and the modules. For this, another contribution of this study was the adaptation of module network methodology, with the inclusion of passengers genes and protein-protein interaction (PPI) as a criteria to select the modules. This analysis was effective in identifying gene modules and related drivers, resulting in the choice of biological pathway potentially responsible for the tumor development. The genes identified after comparing tumor and normal samples (SOX17, TWIST1, CAV1, PPARG, FLI1 and TNFSF10) and the genes identified in the study of positive and negative samples for HPV infection (PCNA, SOX14 and RFC4) were validated in situ by independent techniques. For in silico validation of the changes found in the integrative methodology and the modules network were used 255 samples of glioblastoma multiforme obtained at TCGA database (The Cancer Genome Atlas). Biological pathways have been identified related to the tumoral process, such as cell growth regulation (GO:0001558, $p=6,2 \times 10^{-3}$ ), homeostasis (GO:0048872, $p=8,2 \times 10^{-3}$ ) and transcription regulation (GO:0003700, $p=8,9 \times 10^{-4}$ ). Also, a meta-analysis was performed using samples from TCGA, who found a similar expression profile for CAV1, DLC1, FLI1, MSX1, NRN1, PML, PPARG and SOX17 (T vs N) and PCNA and RFC4 genes (HPV + vs HPV-). To 
our knowledge, this is the first integrative analysis in PeCa using a four-level of gene alterations. In addition, it was found non-random alterations capable to modifying specific transcripts and contribute to the knowledge about the pathobiology of penile tumors.

Keywords: Integrative, cancer, HPV, driver. 


\section{Sumário}

\section{Lista de Abreviaturas}

Lista de Simbolos

Lista de Figuras

\section{Lista de Tabelas}

1 INTRODUÇÃO 1

1.1 Motivação . . . . . . . . . . . . . . . . . . . . . . . . 1

2 REVISÃO BIBLIOGRÁFICA 2

2.1 Biologia de Sistemas e Integração de Informações . . . . . . . . . . . . . . . . 2

2.2 Integração de Dados . . . . . . . . . . . . . . . . . . . . . 4

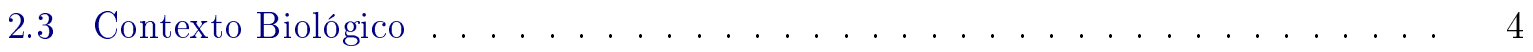

2.4 Algoritmos de Integração de Dados na Literatura . . . . . . . . . . . . . . . . 6

2.5 Grafos, Medidas de Centralidade, Redes Bayesianas e Redes em Módulos . . . . . 11

$2.5 .1 \quad$ Grafos . . . . . . . . . . . . . . . . . . . . 11

2.5.2 Medidas de Rede . . . . . . . . . . . . . . . . . . . . . 11

2.5.3 Redes Bayesianas . . . . . . . . . . . . . . . . . . . . . 13

2.5.4 Rede em Módulo . . . . . . . . . . . . . . . . . . . . . . 14

2.5.5 Câncer de Pênis . . . . . . . . . . . . . . . . . . . . 16

2.6 Aspectos Relacionados ao Papilomavírus Humano (HPV) . . . . . . . . . . . 17

3 JUSTIFICATIVA 20

4 OBJETIVOS 22

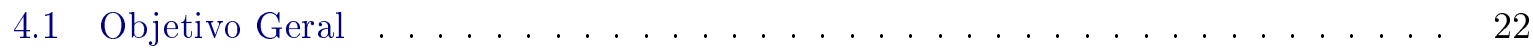

4.2 Objetivos Específicos . . . . . . . . . . . . . . . . . 22

5 MATERIAIS E MÉTODOS 23

5.1 Casuística . . . . . . . . . . . . . . . . . . . . 23

5.2 Metodologia para Integração de Dados . . . . . . . . . . . . . . . . . . . 23

5.2 .1 Primeira Etapa - Pré-Seleção de Genes . . . . . . . . . . . . . . . . . . . . 24

5.2 .2 Redes em Módulos . . . . . . . . . . . . . . . . . . . . . . 26

5.2 .3 Biclusterização Bayesiana - Formação dos Módulos . . . . . . . . . . . . . 27

5.2.4 Associação entre Genes Pré-selecionados e Módulos . . . . . . . . . . . . . . 28

5.2.5 Atribuição de Pontuação ao Regulador . . . . . . . . . . . . . . . . . . . . 30

5.2 .6 Mecanismos para Seleção de Módulos . . . . . . . . . . . . . . . . . . . . 31

5.2.7 Parâmetros Pré-definidos para Formação do Conjunto Driver-Módulo . 31

5.3 Especificação dos Dados e Plataformas . . . . . . . . . . . . . . . . . . . . . 32

5.3.1 Array-Comparative Genomic Hybridization - aCGH . . . . . . . . . . 33

5.3.2 Análise de Expressão Gênica em Larga-Escala (Microarray) . . . . . . . . 34

5.3 .3 Análise de Metilação . . . . . . . . . . . . . . . . . . . . . . . 36 
5.3 .4 Análise de miRNA . . . . . . . . . . . . . . . . . . . . . . . 37

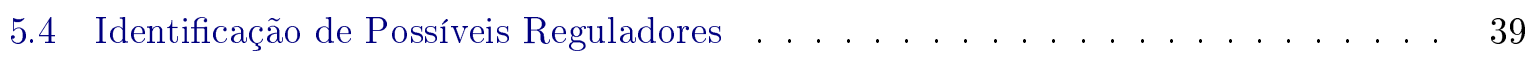

5.5 Meta Análise . . . . . . . . . . . . . . . . . . . . . 41

5.6 Metodologias de Validação in situ e in silico. . . . . . . . . . . . . . . . . . 41

5.6 .1 Validação in situ . . . . . . . . . . . . . . . . . . . . . . . 41

5.6.2 Validação in silico: Redes em Módulos e Metodologia de Integração de Dados 41

6 RESULTADO

6.1 Análise das Características Clínicas e Patológicas . . . . . . . . . . . . . . . 43

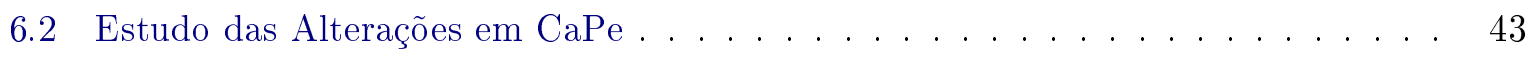

6.2.1 Primeira Etapa - Pré-seleção dos Genes . . . . . . . . . . . . . . . 43

6.2 .2 Seleção de Módulos . . . . . . . . . . . . . . . . . . . . . 50

6.2.3 Atribuição de Genes como Reguladores dos Módulos . . . . . . . . . . . . 51

6.2 .4 Propriedades Topológicas de Redes . . . . . . . . . . . . . . . 56

6.2 .5 Meta-Análise . . . . . . . . . . . . . . . . . 58

6.3 Estudo das Alterações Moleculares em CaPe Segundo a Infecção pelo HPV .. 59

6.3.1 Primeira Etapa - Pré-Seleção dos Genes . . . . . . . . . . . . . . . 59

6.3 .2 Seleção de Módulos . . . . . . . . . . . . . . . . . . . . . . . . . . . . . . . . . . . 64

6.3 .3 Atribuição de Módulos . . . . . . . . . . . . . . . . . . . . . 65

6.3 .4 Propriedades Topológicas de redes . . . . . . . . . . . . . . . . . 70

6.3 .5 Meta-Análise . . . . . . . . . . . . . . . . . . . . 72

6.4 Confirmação e Validação dos Candidatos a drivers por RT-qPCR, qPCR e Pirosequenciamento ( Tumor vs Normal) . . . . . . . . . . . . . . . . 72

6.5 Confirmação e Validação dos Candidatos a drivers por RT-qPCR e Pirosequenciamento $(\mathrm{HPV}+$ vs HPV-) . . . . . . . . . . . . . . . . . 75

6.6 Validação in silico da Metodologia de Redes em Módulos . . . . . . . . . . . . . . 77

6.7 Validação in sílico da Metodologia de Integração de Dados . . . . . . . . . . . . . 78

$\begin{array}{lll}7 & \text { DISCUSSÃO } & 81\end{array}$

8 CONCLUSÕES $\quad 111$

Referências $\quad 112$ 


\section{Lista de Figuras}

1 Representação de grafos direcionados e não direcionados, onde $V$ representa os vértices 1,2 e 3 e $A$, as arestas. . . . . . . . . . . . . . 11

2 Grafo construído a partir de variáveis $(v)$ e suas relações (indicadas por setas) . . 13

3 (A) Representação de uma rede Bayesiana onde a distribuição conjunta é $P(v 1, v 2, v 3, v 4, v 5)=$ $P(v 1) P(v 2) P(v 3 \mid v 1, v 2) P(v 4 \mid v 2) P(v 5 \mid v 3) P(v 6 \mid v 3, v 4)$ e cada vértice representa uma distribuição de probabilidade conjunta. (B) Modelo simplificado de redes com três módulos onde o retângulo pontilhado representa a distribuição da probabilidade condicional. Nesse exemplo, o módulo 3 tem a seguinte distribuição: $P($ Modulo3, v5, v6 $)=P(v 5, v 3)+P(v 6, v 3, v 4)$. (C) Distribuição de probabilidade condicional referente à $P(v 4 v 2)$, e.g. quando $v 2$ têm expressão diminuída, espera-se diminuição na expressão de $v 4 \ldots \ldots \ldots \ldots \ldots \ldots$

4 Representação de um modelo de redes em módulos com três instâncias. A distribuição de probabilidade condicional (DPC) de cada módulo é conectada às variáveis atribuídas ao módulo (e.g. $\theta_{M 2} \mid$ Gene1 é conectado a Gene2, Gene3, Gene4 e Gene5). A estatística de cada DPC é a soma das estatísticas de cada variável atribuída ao módulo e seus pais. . . . . . . . . . . . . . . . . . 16

5 Fluxograma com as etapas de seleção dos genes candidatos à drivers. . . . . . . . .

6 Modelo gráfico de um bicluster para genes e amostras dado uma matriz de expressão gênica e um candidato a regulador. . . . . . . . . . . . . . . . . .

7 Modelo de árvore de regressão com genes enriquecidos para via do ciclo celular. Cada nó (gene) possui dois blocos de decisão acompanhados por um modelo linear. Através de um limiar pré-definido a análise percorre toda a árvore, partindo da raiz até a folha. . . . . . . . . . . . . . . . . . .

8 Fluxograma adaptado de Gertz et al. (2009) mostrando o processo de validação de sondas por posição, categorizando-as como: válidas, possivelmente válidas e inválidas. As sondas inválidas foram excluídas da análise. . . . . . . . . . . . . .

9 (A) Representação do número de genes diferencialmente expressos obtidos da comparação entre amostras tumorais e normais de pênis. A barra na cor preta significa expressão aumentada (3.151/5.251 - frequência de 60\%) e a barra cinza, expressão diminuída (2.100/5.251 - frequência de 40\%). Em (B), gráfico representando o número de genes diferencialmente expressos obtidos da comparação entre amostras positivas e negativas para a infecção pelo vírus. A barra na cor preta representa expressão aumentada (231/475- frequência de 48.6\%) e a barra cinza, expressão diminuída $(244 / 475$ - frequência de $51.4 \%)$. . . . . . . . . . . . . .

10 Representação dos genes com alterações nos níveis de metilação em CaPe (comparação entre amostras tumorais e normais), separados por cromossomo. As barras na cor cinza representam os genes hipometilados e as barras na cor preta, genes hipermetilados. Nota-se uma frequência maior de hipometilação nos cromossomos 7, 16 e 19. Com relação à hipermetilação, os cromossomos 7, 8, 18 e 19 aparecem com maior frequência de alterações. . . . . . . . . . . . . . . . . . . . 
11 Genes metilados na comparação entre amostras positivas e negativas para o HPV em CaPe. As barras na cor cinza e preta representam genes hipometilados e hipermetilados, respectivamente. É possível identificar uma frequência maior de hipermetilação nos cromossomos 1, 2, 17 e 19. Os genes hipometilados se concentram em maior quantidade nos cromossomos 1,17 e $19 \ldots \ldots \ldots \ldots$

12 Método para identificação de possíveis reguladores, considerando os bancos de dados de vias biológicas: KEGG, Pathway Interaction, MetaCyc, Pathguide, e REACTOME e predição de alvos de miRNAs (Targetscan, PicTar, MicroCosm e microRNA). Os genes de entrada associados com a lista de termos mais representativos foram comparados com o banco de dados HTRI (Human Transcriptional Regulation Interaction Database) para seleção de possíveis reguladores. . . . . . . .

13 Representação dos módulos identificados de acordo com a significância estatística definida por $\mathrm{p}<0,05$. Seleção de módulos a partir dos alvos pré-selecionados em amostras de carcinoma de pênis. É possível observar que após 100 simulações a maior concentração de módulos permaneceu próxima de zero. . . . . . . . . . . .

14 Representação da associação entre o regulador BIRC5 e o módulo enriquecido para crescimento celular. Afigura apresenta a matriz de expressão (heatmap) com todas as amostras de câncer de pênis utilizadas nesse estudo e os asteriscos indicam genes identificados como passengers. A função de cada gene pode ser observada na cor laranja, e atribuída a quatro processos biológicos. Nesse caso, o módulo foi enriquecido para via de crescimento celular, com dez genes relacionados a essa função, sendo oito deles identificados comopassengers. A rede representa a interação entre os genes do módulo com o regulador BIRC5, além das interações desses genes com os estudos mais relevantes disponíveis na literatura, representados pelo código de acesso pelo PUBMED. . . . . . . . . . . . . . . . . .

15 Rede de interação entre os genes candidatos a driver e seus módulos correspondentes. As cores estão relacionadas aos módulos e a linha tracejada indica a interação entre eles. É possível observar que o gene $D L C I 1$ apresenta interação com outros quatro candidatos a drivers: BIRC5, RB1, PLCB3 e DNMT1. . . . . . . . .

16 Representação das propriedades topológicas de rede, de acordo com os resultados obtidos nas etapas anteriores. Em (A) foi comparado o grau de conectividade (k) e o coeficiente de clusterização das interações obtidas a partir dos 73 genes candidatos. Em (B), com o mesmo conjunto de genes, foi comparada a conectividade com a centralidade de intermediação. É possível observar que genes que interagem com menos de 30 vizinhos apresentam valores de intermediação abaixo de 4.000 $(0,025)$ e coeficiente de clusterização entre 0,05 e 0,55 . . . . . . . . . . .

17 Representação dos módulos selecionados no estudo sobre a influência do HPV no desenvolvimento do carcinoma de pênis. É possível observar que a maior concentração de módulos foi dentro do limite de significância estabelecido $\left(p<5 \times 10^{-2}\right)$. 
18 Atribuição do gene $P C N A$ como regulador do módulo 5. A matriz apresenta todas as amostras estudadas em câncer de pênis dispostas em colunas e os genes em linhas. Os asteriscos indicam os genes identificados como passengers. Cada gene do módulo foi relacionado a um ou vários processos (representados pela cor azul). No caso do gene PCNA, o módulo foi enriquecido para proliferação celular, e contém cinco genes identificados como passengers. A rede apresenta a interação entre os genes de acordo com sua representatividade além das interações desses genes com estudos publicados na literatura. . . . . . . . . . . . . .

19 Interação entre os módulos regulados pelos genes $P C N A, K L K 10$ e $R F C 4$. Observase uma interação entre os módulos 5 e 8 , ambos enriquecidos para processos envolvendo ciclo celular, regulados pelos genes PCNA e RFC4. O gene SOX14 não apresentava interações com os genes da rede. . . . . . . . . . .

20 Representação das propriedades topológicas de rede, de acordo com os resultados obtidos nas etapas anteriores. Em (A) foi comparado o grau de conectividade (k) e o coeficiente de clusterização das interações obtidas a partir dos quatro genes candidatos. Em (B), com o mesmo conjunto de genes, foi comparada a conectividade com a centralidade de intermediação. É possível observar que genes que interagem com menos de 30 vizinhos apresentam valores de intermediação abaixo 0,05 e coeficiente de clusterização entre 0,10 e $0,70 \ldots \ldots \ldots$. . . . . .

21 Expressão gênica para os candidatos a drivers detectados pela análise integrada em CaPe (Tumor vs Normal). Os níveis de transcritos foram avaliados para CAV1 (A), PPARG (B), PML (C), TNFSF10 (D) e FLI1 (E) por RT-qPCR e comparados entre amostras normais e tumorais. Foi observada expressão aumentada para TNFSF10 (F) e diminuição nos níveis de PPARG (D), CAV1(A) e FLI1 (E). Não foi encontrada alteração de expressão significativa para o gene $P M L(\mathrm{C})$.

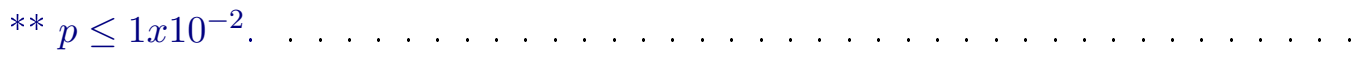

22 Representação gráfica da correlação entre os níveis de metilação, expressão gênica e correlação de Spearman para os genes SOX17 e TWIST1. A figura apresenta a metilação por pirosequenciamento (primeira coluna), expressão gênica por RTqPCR (segunda coluna) e correlação de Spearman (terceira coluna). . . . . . . .

23 Expressão relativa dos genes $R F C 4$ e $P C N A$ em amostras positivas e negativas para infecção pelo HPV. Os níveis dos transcritos $R F C 4$ (A) e PCNA (B) foram avaliados por RT-qPCR e comparados entre amostras de CaPe positivas e negativas para infecção pelo HPV. Foi observada expressão aumentada em casos positivos para HPV para os dois genes avaliados. ${ }^{*} p \leq 0,05$. Imagens geradas no programa GraphPad Prism 5.0 . . . . . . . . . . . . . . . . .

24 Representação dos níveis de metilação para o gene SOX14 na comparação entre casos positivos e negativos para infecção pelo HPV. Foi utilizado o teste estatístico Mann-Whitney, considerando $p<5 x 10^{-2} \ldots \ldots \ldots \ldots$ 


\section{Lista de Tabelas}

1 Algoritmos de integração de dados identificados em literatura. Tipo de integração: S (pipeline) e J (programa fechado), Número de amostras / Tipo: número de amostras utilizadas / tipo de amostras utilizadas para validação do método, Bancos de dados: amostras disponíveis em bancos de dados externos, e.g. TCGA (The Cancer Genome Atlas), disponível em http://cancergenome.nih.gov/, pelo próprio grupo ou em relatos da literatura. Os dados não preenchidos são devido à falta de informações nos artigos. . . . . . . . . . . . . . .

2 Representação de probabilidades condicionais de um vértice em redes Bayesianas. A probabilidade do vértice $v_{4}$ apresentar expressão aumentada, dado que $v_{2}$ tem expressão diminuída é representada por $P\left(v_{4}=1 \mid v_{2}=-1\right)=0.05 . \quad \ldots \ldots$.

3 Representação das alterações do número de cópias do DNA significativamente identificadas pelo algoritmo GISTIC $(p<0,05, q<0,1) \ldots \ldots \ldots$

4 Alterações referentes à comparação entre amostras positivas e negativas para infecção pelo HPV em 31 amostras de carcinoma de pênis. A coluna de frequência representa os valores exclusivos para HPV + em comparação com HPV . . . . . .

5 Representação dos miRNAs diferencialmente expressos obtidos nas comparações entre amostras tumorais e normais de CaPe e positivas e negativas para infecção pelo HPV.

6 Pré-candidatos a driver utilizados como alvos na etapa de inferência de redes em módulos, obtidos na comparação entre amostras tumorais e normais de pênis. Para descrever as alterações, foram utilizadas as seguintes nomenclaturas: [G] = Ganho do número de cópias, $[\mathrm{P}]=$ perda genômica, $[\mathrm{EA}]=$ Expressão aumentada, $[\mathrm{ED}]$ = Expressão diminuída, $[\mathrm{HO}]=$ Hipometilação, $[\mathrm{HE}]=$ Hipermetilação, $[\mathrm{miR}-]=$ Expressão de miRNA diminuída e $[\mathrm{miR}+]=$ Expressão de miRNA aumentada. Estão apresentadas também as pontuações referentes à escolha dos genes. A atividade do gene foi descrita como: $[\mathrm{TS}]=$ Supressor tumoral, $[\mathrm{EC}]=$ Estabilidade celular, $[\mathrm{ON}]=$ Oncogene e $[\mathrm{PQ}]=$ Proteína quinase e $[\mathrm{TF}]=$ Fator de transcrição. 45

7 Genes enriquecidos para diversas funções e doenças. Para o enriquecimento dos 73 genes nas categorias descritas foi considerado um $p<5 x 10^{-5}$. . . . . . .

8 Genes enriquecidos para vias susceptíveis a efeitos toxicológicos, possibilitando a identificação de possíveis biomarcadores. Para escolha das vias significativas foi considerado $p<10^{-} 3 \ldots \ldots \ldots \ldots \ldots \ldots \ldots$

9 Possíveis candidatos a reguladores. A partir de informações disponíveis na literatura foram identificados genes significativamente descritos como possíveis reguladores dos genes selecionados na primeira etapa da metodologia de integração de dados. É possível destacar o gene $R B 1\left(2.17 \times 10^{-7}\right)$, possível regulador dos genes DIO2, DNMT1, KIAA0101, MET, MSX1 e PPARG. Esse gene também foi descrito com função de auto regulação. $[\mathrm{EA}]=$ expressão aumentada, $[\mathrm{ED}]=$ expressão diminuída. . . . . . . . . . . . . . . . . . . 
10 Seleção de 17 possíveis candidatos a driver pela metodologia de integração de dados. Para descrever as alterações, foram utilizadas as seguintes nomenclaturas: $[\mathrm{G}]=$ Ganho do número de cópias, $[\mathrm{P}]=$ perda genômica, $[\mathrm{EA}]=$ Expressão aumentada, $[\mathrm{ED}]=$ Expressão diminuída, $[\mathrm{HO}]=$ Hipometilação, $[\mathrm{HE}]=$ Hipermetilação, $[$ miR- $]=$ Expressão de miRNA diminuída e $[\mathrm{miR}+]=$ Expressão de miRNA aumentada. As funções dos genes foram descritas como: [TS] = Supressor tumoral e $[\mathrm{ON}]=$ Oncogene. . . . . . . . . . . . . . . . .

11 Identificação dos genes candidatos a drivers, atribuídos como reguladores de um ou mais módulos. Observa-se que a inclusão de genes passengers e interação proteínaproteína como critérios de seleção de módulos auxiliou na identificação do módulo 2 como regulado pelo $B I R C 5$, mesmo esse gene tendo sido inferido como regulador dos módulos 4 e 6 . O mesmo pode ser observado para os genes DNMT1 (módulo 0), PPARG (módulo 15), RB1 (módulo 19), TNFSF10 (módulo 78) e TWIST1 (módulo 1). No caso dos candidatos FLI1 (módulo 35), PML (módulo 14) e SOX17 (módulo 23), houve associação de apenas um módulo com cada gene. . . . . . . . .

12 Identificação das propriedades topológicas de rede para cada gene identificado como candidato a driver. Os termos centralidade de grau e centralidade de intermediação correspondem aos termos em inglês degree centrality e betweenness centrality. O gene NRN1 não apresentou interação nos bancos de dados utilizados

13 Meta-análise utilizando 1.066 amostras obtidas no banco de dados TCGA para avaliação da expressão dos 17 genes candidatos a driver obtidos no estudo envolvendo a comparação entre amostras tumorais e normais para carcinoma de pênis. Entre parênteses foi apresentado o número de amostras para cada estudo. [EA] = expressão aumentada e $[\mathrm{ED}]=$ expressão diminuída. Em negrito os genes que apresentaram concordância dos valores de expressão entre todos os estudos . . . .

14 Genes selecionados na primeira etapa de integração dos dados obtidos no estudo envolvendo amostras positivas e negativas para infecção pelo HPV. Para descrever as alterações, foram utilizadas as seguintes nomenclaturas: $[\mathrm{G}]=$ Ganho de cópias, $[\mathrm{P}]=$ Deleção, $[\mathrm{EA}]=$ Expressão aumentada, $[\mathrm{ED}]=$ Expressão diminuída, $[\mathrm{HO}]=$ Hipometilação, $[\mathrm{HE}]=$ Hipermetilação, $[\mathrm{miR}-]=$ Expressão de miRNA diminuída $\mathrm{e}[\mathrm{miR}+=$ Expressão de miRNA aumentada. A atividade dos genes foi descrita como: $[\mathrm{TS}]=$ Supressor tumoral, $[\mathrm{EC}]=$ Estabilidade celular, $[\mathrm{ON}]=$ Oncogene $\mathrm{e}[\mathrm{PQ}]=$ Proteína quinase. $\ldots \ldots \ldots \ldots \ldots \ldots$

15 Genes enriquecidos para diversas funções e doenças na comparação entre amostras e carcinoma de pênis positivas e negativas para infecção pelo HPV. Foi utilizado o critério de significância de $p<5 x 10^{-2} \ldots \ldots \ldots \ldots \ldots$

16 Vias biológicas susceptíveis a efeitos de componentes tóxicos. Para avaliar se os genes identificados no estudo sobre a influência do HPV no desenvolvimento de CaPe estavam presentes em vias susceptíveis a efeitos toxicológicos foi feito um enriquecimento utilizando o banco de dados CTD (Comparative Toxicogenomics Database, disponível em http://ctdbase.org/). Para escolha das vias significativas foi considerado $p<10^{-3} \ldots \ldots \ldots \ldots \ldots \ldots \ldots$ 
17 Possíveis candidatos a reguladores. A partir de informações disponíveis na literatura foram identificados genes significativamente descritos como possíveis reguladores dos genes selecionados na primeira etapa da metodologia de integração de dados (HPV+ vs HPV-). O gene KLF5, mapeado na região 13q22.1, apresentou o menor p-valor $\left(3,06 x 10^{-4}\right)$ para a possível regulação dos genes DUSP1, NOTCH1 e PCNA. $[\mathrm{EA}]=$ expressão aumentada, $[\mathrm{ED}]=$ expressão diminuída. . . . . . . .

18 Lista com os quatro candidatos a driver selecionados pela metodologia de integração de dados. . . . . . . . . . . . . . . . . . . . . . . .

19 Identificação dos genes $K L K 10, R F C 4, P C N A$ e SOX14 como candidatos a driver no estudo das alterações entre pacientes HPV + e HPV-. Os módulos que passaram pelos critérios de seleção foram atribuídos ao conjunto de 35 reguladores e após as etapas de integração de dados, foram selecionados quatro conjuntos (regulador + módulo) para estudos posteriores. Em um caso específico, o gene PCNA, identificado como regulador dos módulos 5,7 e 12, foi selecionado apenas por sua associação com o módulo cinco (enriquecido para a via de proliferação celular, formado por 14 genes, sendo cinco passengers e frequência de PPI de 35,7\% . . . .

20 Identificação de medidas topológicas de rede para cada gene identificado como candidato a driver no estudo sobre alterações obtidas da comparação entre amostras $\mathrm{HPV}+$ e HPV- para carcinoma de pênis. O gene SOX14 não apresentou interações nos bancos de dados pesquisados. . . . . . . . . . . . . .

21 Meta-análise utilizando os bancos de dados TCGA e NCBI-GEO para avaliação da expressão dos quatro genes candidatos a driver obtidos da comparação entre amostras positivas e negativas para infecção pelo HPV. Entre parênteses foi apresentado o número de amostras para cada estudo. [EA] = expressão aumentada e $[\mathrm{ED}]=$ expressão diminuída . . . . . . . . . . . . . . . .

22 Correlação entre resultados obtidos por qPCR e características clínicas e patológicas de 34 pacientes com carcinoma de pênis. E: éxon . . . . . . . . . . . . .

23 Comparação entre a metodologia proposta neste estudo e a utilizada por Segal et al. (2003) e Michoel et al. (2007) utilizando curva ROC e seus parâmetros. Foi avaliada a eficiência para deteç̧ão de genes candidatos presentes na lista de referência. $\mathrm{VPP}=$ valor preditivo positivo, $\mathrm{VPN}=$ valor preditivo negativo, $\mathrm{AUC}=$ área sob

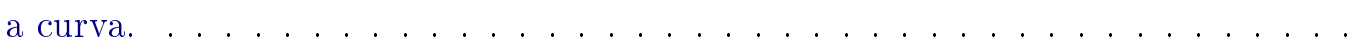

24 Comparação entre a metodologia proposta neste estudo e a utilizada por Segal et al. (2003) e Michoel et al. (2007) utilizando curva ROC e seus parâmetros. Foi avaliada a eficiência para detecção de interações entre reguladores e módulos. VPP = valor preditivo positivo, $\mathrm{VPN}=$ valor preditivo negativo, $\mathrm{AUC}=$ área sob a curva.

25 Comparação entre a metodologia proposta neste estudo e a utilizada por Segal et al. (2003) e Michoel et al. (2007) utilizando curva ROC e seus parâmetros. Foi avaliada a eficiência para detecção de genes passengers nos módulos. VPP $=$ valor preditivo positivo, $\mathrm{VPN}=$ valor preditivo negativo, $\mathrm{AUC}=$ área sob a curva. . . .

26 Módulos e candidatos a drivers selecionados pela metodologia de integração de dados. Em "drogas descritas"são apresentadas drogas cujos alvos foram identificados como possíveis candidatos a drivers . . . . . . . . . . . . . . . 


\section{INTRODUÇÃO}

\subsection{Motivação}

A análise integrada de múltiplos conjuntos de dados é um grande desafio devido à alta dimensionalidade das informações e heterogeneidade entre os estudos (Shuangge et al. , 2011). Em pesquisas sobre o câncer, iniciativas para avaliar alterações genômicas, perfis de metilação e genes diferencialmente expressos revelaram uma variedade de alterações como características tumorais. Individualmente, cada tumor pode apresentar características únicas e abriga um grande número de lesões genéticas, das quais apenas algumas direcionam a proliferação celular e a metástase. Assim, identificar mutações drivers (alterações genômicas resultantes da replicação do DNA da célula tumoral, identificadas com alta frequência e que causam ou ajudam na progressão tumoral) e diferenciá-las das alterações passengers (que não conferem vantagem adaptativa no ambiente celular e geralmente surgem em células que adquiriram mutações drivers) emergiu como um grande desafio na caracterização genômica de doenças. Foi estimado que uma mutação driver atribui uma pequena vantagem adaptativa à célula, na ordem de $0,4 \%$ de aumento na comparação entre o nascimento e morte celular, suficiente para a formação de uma grande massa de bilhões de células mutadas no decorrer dos anos (Bozic et al. , 2010). Entretanto, Vogelstein et al. (2013) apresentaram uma nova classificação para essas alterações: Mut-driver (um gene que apresenta alta frequência de mutações drivers) e Epi-driver (um gene com baixa frequência de mutação mas com expressão alterada resultante da metilação do DNA e modificações da cromatina que persistem durante a divisão de células tumorais). No estudo citado, dentre os cerca de 20.000 genes codificadores de proteínas avaliadas pelo sequenciamento do genoma de 3.284 tumores, com um total de 294.881 mutações relatadas, apenas 125 foram classificados como genes Mut-driver (sendo 71 supressores tumorais e 54 oncogenes). Esse resultado demonstra a importância do desenvolvimento de novas metodologias para seleção de genes que sejam diretamente responsáveis pelo desenvolvimento do câncer e a integração de diferentes níveis de alteração para o aumento da confiabilidade dos resultados obtidos.

No presente estudo foi proposta uma metodologia para integração de alterações do número de cópias do DNA, expressão gênica, metilação de ilhas CpGs e expressão de miRNAs com o objetivo de identificar genes drivers como possíveis candidatos a marcadores moleculares e alvos terapêuticos em carcinomas de pênis $(\mathrm{CaPe})$. Para o nosso conhecimento, há apenas um relato envolvendo a análise de expressão de transcritos usando microarray e não há relatos sobre a aplicação de metodologias de integração de dados em CaPe.

Com relação à organização do trabalho, a introdução foi dividida em três módulos: (1) biologia de sistema e integração de informações; (2) conceito de redes em módulo e redes Bayesianas e (3) influência do Papilomavirus Humano (HPV) no câncer de pênis. O desenvolvimento de uma nova metodologia para integração de múltiplos conjuntos de dados representa a principal contribuição desse trabalho. 


\section{REVISÃO BIBLIOGRÁFICA}

\subsection{Biologia de Sistemas e Integração de Informações}

As células contêm uma grande variedade de estruturas moleculares que se unem para formar complexos dinâmicos que possivelmente podem interagir em redes. O desenvolvimento recente de tecnologias de alto rendimento forneceu aos pesquisadores uma extensa, embora ainda incompleta, lista de genes responsáveis pela função de cada componente celular (Hernandez-Patino et al. , 2013). Um dos grandes desafios dos próximos anos será a montagem sistemática desses componentes, obtidos pelas técnicas de microarray e sequenciamento, em redes moleculares e posteriormente utilizar essas informações para responder perguntas fundamentais sobre os processos responsáveis pela mudança comportamental do sistema celular, e.g., como estes componentes celulares se reúnem para, robustamente, manter sinais de homeostase, processo exógeno e endógeno, e depois coordenar respostas? Como alterações genéticas desregulam a rede e se manifestam em doenças como o câncer? Nesta perspectiva, acredita-se que mesmo com uma compreensão parcial sobre redes moleculares, os pesquisadores estejam prestes a entender a estrutura de redes formadas por genes mutados em uma determinada doença e, em seguida, prever como essas interações podem responder a terapias particulares.

Modelos quantitativos de redes biofísicas abrangendo um pequeno número de componentes têm contribuído para a nossa compreensão sobre redes celulares. Neste processo, é definido um conjunto de pressupostos de modelagem, por exemplo, que as alterações genéticas modificam os processos celulares e podem promover a proliferação do tumor. Em seguida, os dados são utilizados para derivar um modelo específico para cada tumor, que normalmente abriga muitos genes alterados, identificando quais genes direcionam a proliferação. No final, um bom modelo de redes biológicas deve ser capaz de prever o comportamento da rede em diferentes condições e ajudar a projetar uma resposta desejada. Por exemplo, qual parte de uma rede molecular de um tumor deve ser alterada com uma droga para interferir na proliferação celular ou no processo metatástico? Tal compreensão global das redes pode ter valor de transformação, permitindo aos pesquisadores compreender os possíveis erros nas vias da doença e elaborar estratégias terapêuticas atuantes nessas falhas (Pe'er e Hacohen , 2011).

O impacto de modelos globais pode ser notado no estudo de drogas contra o câncer, onde o efeito dificilmente é predito devido ao crosstalk e feedback que ainda são pouco mapeados na maioria das vias de sinalização. Por exemplo, o alvo da rapamicina em mamíferos $m T O R$ é crítica para o crescimento celular e a sua atividade é alterada em muitos tumores, portanto, espera-se que seja um bom alvo terapêutico. No entanto, ela mostra resultados poucos satisfatórios em testes clínicos. Este desvio de expectativas pode ser devido ao feedback e crosstalk entre a Akt/mTOR e a via quinase regulada por sinais extracelulares (ERK) (Carracedo et al. , 2008). A inibição do $m T O R$ induz a inibição por feedback dos receptores tirosina-quinase, que podem ativar tanto ERK quanto AKT (O'Reilly et al., 2006) e, posteriormente, aumentar a proliferação celular. Para o sucesso dessas terapias de alvos, uma visão global da interconectividade de proteínas sinalizadoras e sua influência é crítica. Nesta perspectiva, é importante considerar o estado atual e potencial 
futuro de abordagens computacionais para inferência de redes, com ênfase em aplicações para o câncer.

Princípios sobre inferência de redes moleculares são discutidos por Pe'er e Hacohen (2011) para estudos sobre redes biológicas. Um deles é com relação à estatística decorrente de influências moleculares. Para inferir redes a partir de dados genômicos frequentemente é considerado, a priori, que as influências e interações entre entidades biológicas geram relações estatísticas dos dados observados. Considerando duas proteínas, "A" e "B", se a proteína "A" induz a expressão da proteína "B", então são esperados níveis elevados da proteína "B" sempre que níveis ou estados específicos moleculares de seu ativador "A" estejam elevados. Várias abordagens estatísticas têm sido aplicadas com sucesso à inferência de rede (Basso et al. , 2005; Friedman et al. , 2000), tendo em comum à modelagem do comportamento do alvo em função do seu regulador e a busca pelo conjunto mais preditivo. Como exemplo, as redes Bayesianas foram utilizadas para reconstruir estruturas detalhadas da via de sinalização de células $\mathrm{T}$ humanas utilizando apenas a concentração de fosfoproteínas medidas simultaneamente em células individuais (Sachs et al. , 2005). No entanto, os conjuntos de dados atuais não têm poder estatístico para a aplicação de modelos probabilísticos, até mesmo para redes pequenas. Abordagens direcionadas a dados normalmente exigem centenas de amostras para ganhar poder estatístico na resolução de interações moleculares. Uma estratégia poderosa de biologia de sistemas é abstrair e simplificar os modelos. No conceito tradicional de redes em módulos, descrita por Segal et al. (2003), os genes estão agrupados em módulos que são assumidos como parte de um programa regulador. A justificativa para este agrupamento é que os mesmos circuitos de regulação coordenam a ativação ou repressão de grupos de genes que estão envolvidos no mesmo processo. Com o agrupamento de muitos genes co-expressos, a abordagem de redes em módulos aumenta significativamente o poder estatístico para identificar influências reguladoras (Litvin et al. , 2009).

Outro princípio que pode auxiliar na modelagem de redes biológicas é com relação ao dinamismo das redes. Redes moleculares não são estáticas, e por esse motivo apresentam adaptações dinâmicas em resposta aos sinais internos e externos. Influências que determinam o contexto da rede podem ser divididas em três categorias: (1) a herança genética que determina o comportamento da rede e dá origem a diferenças significativa entre os indivíduos; (2) linhagens celulares com diferentes estruturas de rede por apresentarem mudanças epigenéticas e expressão diferencial de genes em ambiente controlado e (3) sinais exógenos, tais como os nutrientes e outras substâncias químicas que podem afetar as redes. No câncer, o contexto pode ter um grande impacto na forma como pacientes respondem a terapias. Em estudos clínicos recentes de uma nova geração de terapias gene-alvo (e.g. Gleevec, Herceptine e inibidores BRAF para a leucemia mielóide crônica, câncer de mama e melanoma), pacientes com o mesmo tipo tumoral e que compartilham mutações-alvo mostravam respostas substancialmente variáveis para as drogas (Sharma et al. , 2010). Além disso, em outro estudo recente a terapia foi extremamente eficaz ao reverter tumores em pacientes com melanoma metastático que eram portadores da mutação do gene BRAF (Flaherty et al. , 2010), pois o fármaco corretamente desliga a via ERK que é fundamental para esse tipo de câncer. No entanto, o mesmo fármaco induz à ativação da via do ERK em células com o tipo BRAF selvagem (Poulikakos et al. ,2010), potencialmente promovendo o desenvolvimento tumoral nessas células. Portanto, para compreender a função da rede tumoral, resposta e resistência a fármacos, os tumores devem ser sistematicamente analisados 
com diferentes estímulos e drogas, seguidos por medições de séries temporais.

\subsection{Integração de Dados}

A disponibilidade de sequências genômicas completas, juntamente com a predição de genes, resultou no desenvolvimento de tecnologias que permitem a associação de genes com determinados módulos biológicos. Outras abordagens genômicas e proteômicas mais recentes incluem interações proteína-proteína (PPI, do inglês Protein-Protein Interaction e proteína-DNA (Interatoma). Essas abordagens em larga-escala já foram utilizadas em muitos processos biológicos, resultando em conjuntos de genes potencialmente envolvidos em doenças (Billur et al. , 2013; Ghersi e Singh , 2013; Kutalik et al. , 2008; Morris et al., 2012). Muitas dessas informações podem ser obtidas em bancos de dados públicos como o GEO (Gene Expression Omnibus, disponível em http://www.ncbi.nlm.nih.gov/geo/ e ArrayExpress (disponível em http: //www.ebi.ac.uk/arrayexpress/ possibilitando a visualização dos dados em conjunto.

Com relação à integração de dados obtidos a partir do mesmo paciente, é possível encontrar inúmeros trabalhos utilizando dados de alteração do número de cópias (CNA) e expressão gênica. Porém, nota-se um número menor de relatos em literatura envolvendo outros tipos de integração, e.g. CNA e metilação, CNA e miRNA, metilação e miRNA. Se por um lado o número de ferramentas ainda é limitado, o número de amostras que possui dados para diversas técnicas tem crescido substancialmente. O projeto TCGA ( The Cancer Genome Atlas, disponível em http://cancergenome.nih.gov, desenvolvido pelo NCI (National Cancer Institute) para produção de dados em larga escala sobre o câncer, possibilita diversos estudos com essas informações. $\mathrm{O}$ NCI é responsável pela produção de diferentes tipos de dados, incluindo expressão gênica, alterações do número de cópias genômicas, metilação do DNA e expressão de miRNAs para os mesmos conjuntos de pacientes em diferentes tipos tumorais. O desafio, entretanto, é a diferenciação entre alterações que promovem o crescimento tumoral de outras alterações que parecem cada vez mais aleatórias e se acumulam como consequência da instabilidade induzida pela tumorigênese. Integrar os dados obtidos por diferentes estratégias tem auxiliado nessas descobertas.

O objetivo da integração de dados não é somente melhorar anotações funcionais, mas também ajudar na formulação de hipóteses biológicas. Uma rede hipotética de proteínas cujos genes estão expressos de forma semelhante em diversas condições experimentais e que mostram perda de função fenotípica é mais provável que seja relevante in vivo do que qualquer outra rede para o qual estas informações adicionais não estejam disponíveis. Assim, desde a última década foram desenvolvidas várias metodologias capazes de integrar diferentes informações. Embora cada método seja formulado exclusivamente para o tipo de dado utilizado, as tendências gerais podem ser deduzidas em uma inspeção mais próxima dos algoritmos. Por exemplo, todos os métodos de integração tem uma entrada comum dos conjuntos de dados sob a forma de matrizes de genes por amostras.

\subsection{Contexto Biológico}

A importância das alterações somáticas envolvendo ganhos ou deleções genômicas é evidente nos casos de oncogenes e genes supressores tumorais (GST) que também apresentam alterações na sua expressão. Exemplos de genes identificados a partir de alterações cromossômicas (amplificações e deleções) envolvem oncogenes importantes como o ERBB2 (Godolphin e Jones, 
1989), MYC (Schwab e Lin , 1983), CCND1 (Dowdy e Eaton , 1984), CAD (Wahl et al. , 1979), ABL (Kononen e Palmberg , 1997), e os supressores tumorais PTEN (Li et al. , 1997), CDKN2A (Lacombe e Hannon , 1995), RB1, BRCA 1, BRCA2, PTPRJ e TP53 (Baker et al. , 1990; Cavenee et al. , 1983; Nagai et al., 1994; Ruivenkamp et al., 2002). Albertson et al. (2004) estudaram os padrões de CNA (do inglês, Copy Number Alterations em 26 tipos de carcinomas e encontraram uma média de 24 ganhos e 18 perdas por amostra em cada tumor. A descoberta e a avaliação funcional dos oncogenes e supressores tumorais são essenciais para a compreensão da biologia do câncer e para o tratamento clínico da doença. Na última década, foram descritos perfis de CNA e expressão gênica para diferentes tipos tumorais utilizando as tecnologias de microarray. Outros métodos experimentais também fornecem informações sobre alterações do número de cópias do DNA, porém variam em termos de resolução. Tanto aCGH (do inglês array-Comparative Genomic Hybridization quanto as novas técnicas de sequenciamento têm sido usadas para obtenção de informações de alta resolução (Akalin et al. , 2013; Romania et al. , 2013). No estudo de Cirilo et al. (2013) foi utilizado o algoritmo CONEXIC (Akavia et al. , 2010) para integração de dados de aCGH e expressão gênica de 51 amostras de Leiomioma Uterino para a identificação de genes drivers. Considerando também alterações genômicas e trancriptômicas, Feik et al. (2013) combinaram dados obtidos a partir de 48 amostras de pacientes com câncer de próstata para a identificação de genes responsáveis pela progressão tumoral, porém nenhum algoritmo ou método específico de integração de dados foi citado. Abordagem semelhante foi utilizada por Brown et al. (2012) para integração de expressão gênica e CNA de 161 amostras de Leucemia Linfocítica Crônica (LLC).

As tecnologias em larga escala também permitiram a ampliação de estudos envolvendo alterações dos níveis de metilação do DNA. A metilação consiste em uma modificação covalente do DNA na qual um grupamento metil (CH3) é transferido da s-adenosilmetionina para o carbono 5 de uma citosina (5-MeC) que geralmente precede a uma guanina (dinucleotídeo CpG), pela ação de uma família de enzimas que recebe o nome de DNA metiltransferase (DNMT) (Jones , 2012). Esse tipo de controle epigenético é essencial para a diferenciação embrionária e neuronal, porém sua função no genoma ainda é pouco compreendida. Análises evolutivas recentes entre espécies sugerem que a metilação do DNA em éxons é uma marca ainda mais antiga, anterior à divergência de plantas e animais (Zemach et al. , 2010).

Diversas pesquisas sobre metilação do DNA em doenças como o câncer têm mostrado que os genomas de células cancerosas apresentam hipometilação global quando comparados com células normais, com exceção da hipermetilação em genes envolvidos na regulação do ciclo celular, invasão de células tumorais, reparo do DNA e outros eventos onde o silenciamento propaga a metástase (Gerhauser , 2013). Estudos sobre metilação global tem contribuído significativamente para o entendimento da influência epigenética e do controle da expressão gênica em diversas doenças (Zouridis et al. , 2012).

Além das alterações do nível de metilação, outros mecanismos também são responsáveis pela alteração do nível de transcritos codificadores. Em revisão publicada por Pritchard et al. (2012) é descrita a ação de miRNAs no controle da expressão gênica, degradando ou reprimindo a tradução de moléculas-alvo de mRNA e participando de doenças como o câncer. O mecanismo de repressão da expressão envolve a degradação do mRNA e inibição da tradução do mRNA por meio do complexo miRNA e RISC (complexo de silenciamento induzido pelo RNA). Dependendo 
da complementaridade entre as bases do miRNA e do mRNA uma das vias regulatórias pode ser utilizada: a via do pequeno RNA de interferência (siRNA) e a via do miRNA. Se a complementaridade entre mRNA e miRNA for quase perfeita, o mRNA será processado pela via siRNA (O'Carroll e Schaefer , 2013). Até o momento, 1.872 miRNAs foram caracterizados em humanos (mirBase, acessado em 10-12-2013) e devido à regulação de múltiplos mRNA-alvos por esses miRNAs estima-se que eles sejam responsáveis pelo controle da expressão de cerca de 30\% dos genes codificadores de proteínas. Com isso, os miRNAs podem ser considerados uma das classes de reguladores mais abundantes em humanos, desempenhando uma função essencial no processo de regulação gênica (Sassen et al. , 2008).

Pesquisas revelam que os miRNAs podem atuar como supressores tumorais ou oncogenes (Wang et al. , 2010). Vários relatos indicam que os miRNAs oncogênicos apresentam expressão aumentada em tumores malignos e são responsáveis pela proliferação celular e inibição de genes que controlam a apoptose (Hirata et al. , 2012; Malumbres , 2012). Por sua vez, alguns miRNAs apresentam expressão reduzida em tumores malignos, sendo considerados supressores tumorais (Jia et al. , 2012; Sonkoly et al. , 2012,?; Venkataraman et al. , 2013). Estes miRNAs atuam contra o desenvolvimento de neoplasias por meio da inibição de oncogenes.

Alguns exemplos de miRNAs com atividades oncogênicas, particularmente em tumores de células germinativas testiculares, são has-miR-155, hsa-miR-372 e has-miR-373 (Tam et al. , 1997; Voorhoeve et al. , 2006). Lu et al. (2005) foram os primeiros a demonstrar que a expressão de muitos miRNAs estava significativamente reduzida em diversos tipos de carcinomas, sugerindo uma atividade de supressor tumoral. A família hsa-let- 7 foi o primeiro grupo de miRNAs ao qual se atribuiu atividade regulatória sobre a expressão de um oncogene. Estudos de Johnson et al. (2005) demonstraram que a expressão aumentada da proteína RAS em câncer de pulmão estava correlacionada com a expressão reduzida de has-let- $\%$.

Algumas iniciativas para a integração de miRNA e outros mecanismos têm sido publicadas: miRNA e expressão gênica (Yan et al. , 2012), miRNA e metilação (Huang et al. , 2012), miRNA e alteração do número de cópias genômicas (Bayani et al. , 2013). Estes estudos têm contribuído para o entendimento dos mecanismos responsáveis pelo desenvolvimento de doenças como o câncer.

\subsection{Algoritmos de Integração de Dados na Literatura}

É possível identificar inúmeros dados de CNA e expressão gênica depositados em bancos de dados públicos, e.g. PUBMED (disponível em www.ncbi.nlm.nih.gov/pubmed) e ArrayExpress (disponível em www.ebi.ac.uk/arrayexpress). Consequentemente, também são encontradas em maior número ferramentas e métodos disponíveis para analisar esses tipos de dados.

O software iCluster, desenvolvido por Shen et al. (2009), utiliza uma abordagem integrativa baseada em um modelo variável de integração. A principal idéia por trás do iCluster é a modelagem dos subtipos tumorais como variáveis não observadas (latentes) que podem ser simultaneamente calculadas a partir das alterações do número de cópias, expressão dos mRNAs e outros dados disponíveis. Além disso, o programa utiliza conceitos de PCA (do inglês, Principal Component Analysis) e EM (do inglês, Expectation-Maximization) como etapas de análise. Já o programa InCroMap (Wrzodek et al. , 2013) é uma plataforma Java que realiza o cruzamento entre várias informações, permitindo a visualização integrada dos resultados obtidos e identi- 
ficação das vias relacionadas com cada gene. Ambas as ferramentas não tem como objetivo a identificação de genes drivers.

Especificamente sobre a integração de CNA e expressão gênica, diversos algoritmos têm sido disponibilizados na literatura. Em 2007, Hupé et al. desenvolveram a ferramenta ACTuDB, baseada em uma estrutura cliente-servidor, (disponível em http://bioinfo.curie.fr/actudb) que armazena 4.802 amostras disponíveis de diferentes tipos tumorais, e.g., câncer de pulmão, bexiga, cérebro, mama, cólon, fígado, linfoma, entre outros. Nesse mesmo estudo, com a utilização de 98 amostras de câncer de bexiga, foram identificados os genes E2F3, CDKAL1, SOX4 (os três mapeados no cromossomo 6), COX6C (cromossomo 8) e CCND1 (cromossomo 11), todos envolvidos em carcinomas humanos. O programa $A C T u D B$ não permite a entrada de dados experimentais pelo usuário, mas disponibiliza 49 estudos envolvendo CNA, expressão gênica e/ou LOH (do inglês, Loss of Heterozygosity - perda de heterozigose).

O Asterias, desenvolvido por Diaz-Uriarte et al. (2007), não possui nenhuma validação disponível e o website descrito no artigo não permite mais o acesso ao programa. Segundo os autores, o processamento dos dados é realizado em 30 dual-CPU com Debian GNU/Linux, acelerando a análise. Semelhante ao que foi descrito por Hupe et al. (2007), este software não permite a entrada de dados experimentais.

Lee e Kim (2009) utilizaram o programa CHESS (CgHExpreSS) para integrar expressão gênica e CNA obtidos a partir de 35 amostras de carcinoma colorretal. Os autores relataram que a região 7 p13 estava significativamente correlacionada com a via biológica do $E G F R$ em glioblastoma multiforme, $13 q$ estava correlacionado com a via do $N F-k a p p a \beta$ em câncer de bexiga e 11p com a via do $R E C K$ (inibidor associado à membrana) em câncer de mama.

Salari et al. (2010) desenvolveram o DR-Integrator (DNA/RNA-Integrator, disponível em http://pollacklab.stanford.edu/) que utiliza testes de correlação (e.g. correlação de Pearson, correlação ordenada de Spearman e teste-t) para integrar dados de alterações genômicas e de expressão gênica global. Não foi realizada nenhuma validação referente aos achados obtidos quando da análise do DR-Integrator.

O algoritmo MAGIA (disponível em http://gencomp.bio.unipd.it/magia) desenvolvido por Bisognin et al. (2012), permite a integração de dados de miRNA e expressão de transcritos codificadores por meio de um modelo de múltiplas etapas com correlação, modelo Bayesiano, informação mútua e uma meta-análise baseada em uma combinação de p-valores. Utilizando dados públicos de leucemia linfoblástica aguda (disponíveis em http://ncbi.nlm.nih.gov/geo, código de acesso: GSE14834), foram identificadas 468 interações miRNA-mRNA (249 apresentaram correlação positiva e 219 correlação negativa), onde 23 apresentavam FDR $<0.1$. Entre as correlações, foram identificadas alterações da família $R A S$, altamente associadas com o hsa-let- $7 d$ ( $\mathrm{r}=-0.82)$

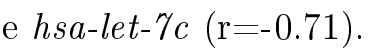

O programa SEURAT (disponível em http://seurat.r-forge.r-project.org/), desenvolvido por Gribov et al. (2010), permite a integração de dados de aCGH, expressão gênica e dados clínicos. Foram realizados testes em pacientes com leucemia mielóide aguda utilizando o algoritmo GLAD (Gain and Loss Analysis of DNA, disponível em http://www.bioconductor.org/packages/2.14/ bioc/html/GLAD.html) para a identificação de regiões genômicas alteradas. Não foram apresentados os detalhes sobre a validação desse método.

van Wieringen et al. (2012) desenvolveram o algoritmo sigaR (disponível em http://www. 
bioconductor.org/packages/2.12/bioc/html/sigaR.html) constituído de duas etapas: cghCall-class e ExpressionSet-object que utiliza pacotes do Bioconductor (disponível em http://www.bioconductor. org) como CGHbase (disponível em http://www.bioconductor.org/packages/2.14/bioc/html/CGHbase. html) e Biobase (disponível em http://www.bioconductor.org/packages/2.12/bioc/html/Biobase. html) para normalização dos dados, identificação de regiões genômicas significantes e anotação. A integração é obtida por uma sobreposição dos dados identificados, utilizando como referência cinco estudos obtidos da literatura, com o objetivo de remover qualquer diferença na distância entre as sondas das diferentes plataformas utilizadas.

O programa SIGMA desenvolvido por Chari et al. (2006) armazena 267 trabalhos que utilizaram linhagens celulares e serve como informação a priori para estudos de aCGH. A integração de alterações do número de cópias do DNA e metilação em amostras de câncer de pulmão identificou ganhos em 1q21.2 e 1q23.1, hipometilação em 1q21.3 e expressão aumentada do gene S100A10, mapeado na região 1q21.

Conde et al. (2007) criaram o ISACGH (disponível em http://isacgh.bioinfo.cipf.es) que permite a integração de CNA e expressão gênica utilizando teste-t como método estatístico. Para a análise de CNA, são utilizados os algoritmos GLAD e CBS (Olshen et al. , 2004), além de anotação e enriquecimento gênico pelo programa FatiGO (Al-Shahrour et al. , 2004). Utilizando amostras de pacientes com mieloma múltiplo foi identificada amplificação em 18q21 e expressão aumentada dos genes BCL2, MALT1, NEDD4L, MBD2, TNFRSF11A e TCF4. O enriquecimento dos genes selecionados resultou na identificação da via de regulação do processo celular (GO:0050794) e regulação do processo fisiológico (GO:0050791), com p <0,01.

van Wieringen et al. (2006) desenvolveram o programa ACE-it (disponível em http://ibivu. cs.vu.nl/programs/acewww/) que utiliza o teste de Wilcoxon e a correção de Benjamini-Hochberg para comparação de dois grupos, i.e., CNA e expressão gênica. Utilizando amostras de carcinomas de mama obtidas no estudo de Pollack et al. (2002) foram identificados genes significantes, com destaque para o HER-2/neu (c-erbB-2) cuja amplificação foi encontrada em aproximadamente $30 \%$ dos casos.

Bicciato et al. (2009) desenvolveram um algoritmo para a identificação de SODEGIRs (do inglês, Significant Overlap of Differentially Expressed and Genomic Imbalanced Regions) que permite a integração de alterações genômicas e de transcritos. Para validação da metodologia, foram utilizadas amostras de astrocitomas e câncer renal. Foram identificadas regiões com amplificações e deleções localizadas nos cromossomos 1q, 3q, 4p, 10p e 17q e nos cromossomos 3p, 14q e 21q, respectivamente, com concordância da expressão de genes mapeados nestas regiões.

O EDIRA (disponível em http://www.statistik.tu-dortmund.de/ schaefer/) é um algoritmo desenvolvido por Schäfer et al. (2009) que permite a utilização do teste de correlação de Wilcoxon para dois grupos de dados: CNA e expressão gênica. Sua eficiência foi testada em amostras de leucemia mielóide aguda revelando alterações em 5q, 7p e 17p com valores significantes para perda genômica e expressão diminuída de genes mapeados nestas regiões. Mais recentemente, Louhimo e Hautaniemi (2011) desenvolveram o programa CNAmet que permite integrar dados de CNA, expressão gênica e metilação, pontuando as alterações como 0 ou 1 de acordo com os diferentes critérios para cada plataforma, e.g. em CNA o valor 1 significa amplificação e 0, ausência de amplificação. Os dados foram testados em 50 amostras de glioblastoma multiforme (GBM) com a identificação de genes importantes como MDM2 EGFR e PDGFRA, previamente 
relatados em processos tumorais.

O algoritmo CONEXIC, desenvolvido por Akavia et al. (2010) (disponível em http://www. c2b2.columbia.edu/danapeerlab/html/conexic.html), utiliza conceitos de redes em módulos para a identificação de genes reguladores e permite a entrada de alterações em nível genômico e transcriptômico. A metodologia foi testada em amostras de melanoma, levando a identificação dos genes TBC1D16 e RAB27A como importantes para o desenvolvimento da doença. Esse algoritmo também foi utilizado no estudo de Cirilo et al. (2013) avaliando 51 amostras de leiomioma uterino e identificando 30 genes candidatos à driver, dos quais dois (FGFR1 e IGFBP5) foram selecionados para validação pela técnica de RT-qPCR (Tabela 1). 
Tabela 1: Algoritmos de integração de dados identificados em literatura. Tipo de integração: S (pipeline) e J (programa fechado), Número de amostras / Tipo: número de amostras utilizadas / tipo de amostras utilizadas para validação do método, Bancos de dados: amostras disponíveis em bancos de dados externos, e.g. TCGA (The Cancer Genome Atlas), disponível em http://cancergenome.nih.gov/, pelo próprio grupo ou em relatos da literatura. Os dados não preenchidos são devido à falta de informações nos artigos.

\begin{tabular}{|c|c|c|c|c|}
\hline Metodologia & $\begin{array}{c}\text { Tipo de } \\
\text { Integração }\end{array}$ & Referência & $\begin{array}{l}\text { Dados para } \\
\text { Integração }\end{array}$ & $\begin{array}{c}\text { oode amostras } \\
\text { Tipo }\end{array}$ \\
\hline $\mathrm{ACTuDB}$ & $\mathrm{S}$ & Hupe et al.(2007) & aCGH, dados clínicos, LOH, expressão & 834 amostras, 49 estudos \\
\hline Asterias & $\mathrm{S}$ & Diaz Uriarte et al. (2007) & aCGH, expressão & - \\
\hline CHESS(CgHExpreSS) & $\mathrm{J}$ & Lee et al. (2009) & aCGH, expressão & - \\
\hline DR Integrator & $\mathrm{S}, \mathrm{J}$ & Salari et al. (2010) & aCGH, expressão & 50 amostras/linhagem \\
\hline MAGIA2 & $\mathrm{J}$ & Bisognin et al. (2012) & miRNA, expressão & - \\
\hline SEURAT & $\mathrm{J}$ & Gribov et al. (2010) & expressão, SNP, CGH & - \\
\hline VanWieringen & $\mathrm{S}, \mathrm{J}$ & Wieringen, (2012) & aCGH, expressão & 41 amostras/tumor \\
\hline SIGMA & $\mathrm{S}, \mathrm{J}$ & Chari et al. (2006) & aCGH, expressão & 267 amostras/14 tipos de tecido \\
\hline ISACGH & $\mathrm{S}$ & Conde et al. (2007) & aCGH, expressão & - \\
\hline Ace it & $\mathrm{S}$ & Wieringen et al. (2006) & aCGH, expressão & - \\
\hline SODEGIR & $\mathrm{S}$ & Bicciato et al. (2009) & aCGH, expressão & 329 amostras/tumor \\
\hline EDIRA & $\mathrm{S}$ & Schafer et al. (2009) & aCGH, expressão & 33 amostras/tumor \\
\hline CNAmet & S & Louhimo et al. (2011) & aCGH, expressão e metilação & $50 \operatorname{amostras}(\mathrm{GBM}-\mathrm{TCGA}) /$ tumor \\
\hline iCLUSTER & $\mathrm{J}$ & Shen et al. (2009) & aCGH, expressão, e metilação & 91 amostras/tumor \\
\hline Conexic & $\mathrm{J}$ & Akavia et al. (2010) & aCGH, expressão & 65 amostras/tumor \\
\hline
\end{tabular}




\subsection{Grafos, Medidas de Centralidade, Redes Bayesianas e Redes em Módulos}

\subsubsection{Grafos}

Tipicamente, um grafo é formado por um conjunto de vértices $(V)$ conectados por arestas $(A)$ e representado por $G=(V, A)$. De acordo com a aplicação, as arestas podem ser direcionadas, e são representadas por "setas". Se $G$ for a representação de um grafo, o conjunto dos seus vértices é denotado por $V(G)$ e o conjunto das suas arestas por $A(G)$. O número de vértices de $G$ é denotado por $n(G)$ e o número de arestas por $m(G)$, portanto, $n(G)=|V(G)|$ em $(G)=|A(G)|$. Em um grafo direcionado, as duas direções são contadas como sendo arestas dirigidas distintas e são apresentadas em pares. Por exemplo, a aresta $\left(v_{2}, v_{3}\right)$ é direcionada a partir de $v_{2}$ até $v_{3}$, sendo diferente do par $\left(v_{3}, v_{2}\right)$, de $v_{3}$ para $v_{2}$ (Figura 1 ). Já em grafos não direcionados as arestas são representadas por pares não-ordenados de vértices e as direções de $v_{2}$ para $v_{3}\left(v_{2}, v_{3}\right)$ ou de $v_{3}$ para $v_{2}\left(v_{3}, v_{2}\right)$ tem o mesmo efeito.

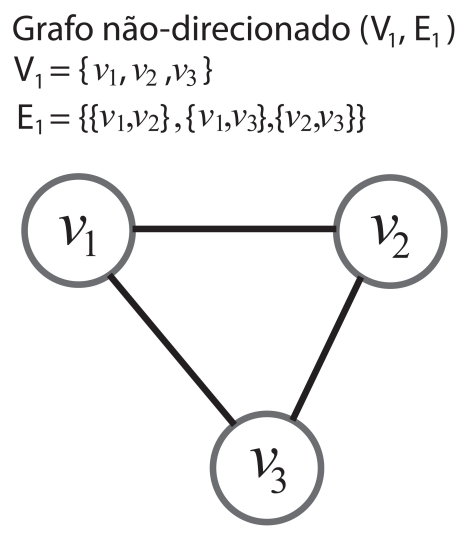

$$
\begin{aligned}
& \text { Grafo direcionado }\left(\mathrm{V}_{2}, \mathrm{E}_{2}\right) \\
& \mathrm{V}_{2}=\left\{v_{1}, v_{2}, v_{3}\right\} \\
& \mathrm{E}_{2}=\left\{\left\{v_{1}, v_{2}\right\},\left\{v_{1}, v_{3}\right\},\left\{v_{2}, v_{3}\right\},\left\{v_{3}, v_{2}\right\}\right\}
\end{aligned}
$$

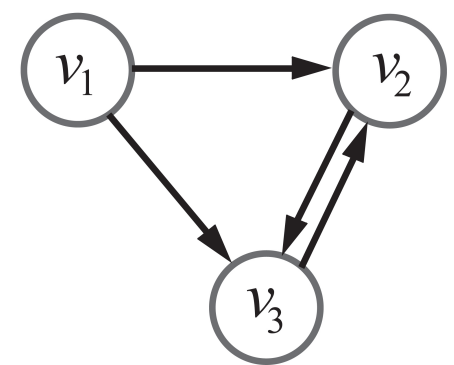

Figura 1: Representação de grafos direcionados e não direcionados, onde $V$ representa os vértices 1,2 e 3 e $A$, as arestas.

Com relação às outras medidas, os vizinhos $N(v)$ do vértice $v$ são definidos como um conjunto de vértices diretamente conectados a $v$. O grau $k(v)$ de $v$ é o número de arestas conectadas ao vértice. Um caminho é definido como uma sequência de vértices $\left(v_{1}, \ldots, v_{n}\right)$ onde para cada um há uma aresta para o vértice posterior. O comprimento de um caminho é o número de arestas na sequência do vértice. A distância entre dois vértices, $v_{1}$ e $v_{2}$, é o comprimento do seu caminho mínimo. O coeficiente de clusterização $C^{c l u}$ de um vértice $v$ é representado pelo número de interações desse vértice com a vizinhança, dividido pelo número de interações que podem existir entre eles, onde $C_{v}^{c l u}=\frac{2\left|\left\{e\left(v_{1}, v_{2}\right)\right\}\right|}{k(v)(k(v)-1)}: v_{1}, v_{2} \in N(v), e\left(v_{1}, v_{2}\right) \in E$.

Em outras palavras, $\left|e\left(v_{1}, v_{2}\right)\right|$ fornece o número de triângulos que atravessam o vértice $\mathrm{v}$, enquanto $\frac{k(v)(k(v)-1)}{2}$ é o número total de triângulos que poderiam passar por v. Portanto o coeficiente de clusterização do vértice $v$ indica como os vizinhos de $\mathrm{v}$ são bem conectados entre sí. O $C^{c l u}$ de um grafo é a média do coeficiente de clusterização de todos os vértices do grafo. A média do comprimento dos caminhos de um grafo é a média dos caminhos mínimos de todos os pares de vértices no grafo.

\subsubsection{Medidas de Rede}

O conceito de centralidade surgiu da ideia de que uma pessoa mais próxima a outra terá mais acesso a informações que outras pessoas menos próximas (Freeman , 1978). Diversas medidas para 
centralidade, tais como grau de conectividade, grau de intermediação ou grau de centralização podem sugerir a importância do vértice na rede (Chen et al. , 2008). Extrapolando os conceitos para a biologia, quando dispostos em forma de redes, os genes podem ser observados pelos tipos de interações ou de acordo com o número de interações que realiza definido como grau de conectividade. Especificamente:

Centralidade de grau (Degree Centrality): é definido pelo número de conexões do vértice com os demais vértices na rede. No contexto biológico, um gene que apresenta um alto grau de conectividade $(h u b)$ pode desempenhar um papel importante em vias biológicas. Se o grafo for dirigido definem-se duas centralidades de grau: de saída e de entrada. A medida pode ser representada por:

$$
C_{g}(v)=k(v)
$$

onde $v$ representa o vértice (nó ou gene) e $\operatorname{deg}(v)$ a quantidade de interações realizadas por esse vértice.

Centralidade de intermediação (Betweenness Centrality): é o número de geodésicos (menor caminho entre dois nós) utilizando o vértice como passagem. Um gene com alto grau de intermediação pode funcionalmente operar como intermediador na rede. O cálculo do grau de intermediação de um vértice $v$ em um grafo $G$ considera os caminhos mínimos entre um par de vértices $\left(v_{1}, v_{2}\right)$, em seguida determina a fração de caminhos mais curtos que passam através do vértice em questão para cada par e soma esta fração de todos os pares de vértices $\left(v_{1}, v_{2}\right)$, representando:

$$
C_{B}(v)=\sum_{v_{1} \neq v \neq v_{2} \in V} \frac{\left(n_{v_{1}, v_{2}}\right)(v)}{n_{\left(v_{1}, v_{2}\right)}}
$$

onde $n_{v_{1}, v_{2}}$ é o número total de caminhos mínimos desde o vértice $v_{1}$ até o vértice $v_{2}$ e $n_{v_{1}, v_{2}}(v)$ é o número desses caminhos que passam por $v$.

Coeficiente de clusterização: O coeficiente de clusterização é uma medida do grau em que os nós de um grafo tendem a se agrupar. Evidências sugerem que na maioria das redes reais, e, em particular, redes sociais, os nós tendem a criar grupos coesos. Mais precisamente, o coeficiente de clusterização de um nó é razão entre as interações existentes, conectando os vizinhos de um nó, sobre a quantidade máxima das possíveis conexões. Um alto valor para essa medida é uma indicação de que essa rede apresenta a topologia de mundo-pequeno (do inglês, small-world). O coeficiente de clusterização do $i$-th nó é representado por:

$$
C_{i}=\frac{2 e_{i}}{k_{i}\left(k_{i}-1\right)}
$$

onde $k_{i}$ é o número de vizinhos do $i$-th nó e $e_{i}$ é o número de conexões entre esses vizinhos.

Segundo Moody et al. (2005), a centralidade permite identificar quais são os vértices de maior importância em uma rede. Intuitivamente, são considerados mais importantes aqueles vértices que apresentam maior grau de conectividade ou maior volume de conexões. Porém, conceitos que estabelecem a importância de um vértice relacionado com o seu volume de conexões podem conduzir a falsas conclusões sobre a estrutura funcional que é representada pelo grafo. Estas medidas se relacionam com propriedades funcionais de genes, e.g. a proximidade entre duas 
proteínas em uma rede de interação. Propriedades de rede também parecem ser preditivas da função da proteína, e.g. genes altamente conectados e centrais tendem a ser fisiologicamente mais importantes e menos dispensáveis (Jeong et al. , 2000; Wuchty e Almaas , 2005).

Embora diferentes estudos tivessem como foco conjuntos diferentes de genes na doença, eles chegaram a algumas conclusões semelhantes. Especificamente, descobriram genes mais relacionados a doenças codificam proteínas não $h u b$ e tendem a ser intermediários com relação ao grau de interação (Feldman et al. , 2008; Goh et al. , 2007). O conhecimento atual das propriedades de redes de doenças é limitado por uma série de razões. O primeiro problema é que medidas de propriedades de rede amplamente utilizadas estão fortemente correlacionadas umas com as outras, tornando difícil a comparação entre os diferentes estudos. O segundo problema é que muitos estudos agrupam genes de doenças complexas e mendelianas detectados em genealogias ou baseados em estudos de associação global do genoma (GWAS, do inglês Genome-Wide Association Study).

\subsubsection{Redes Bayesianas}

Uma rede Bayesiana pode ser vista como um modelo que utiliza a teoria dos grafos, cadeias de Markov e a distribuição de probabilidades para representar uma situação, suas variáveis e estados, e a partir disso realizar inferências (Dougherty , 2007). Conforme dito anteriormente, redes gênicas construídas a partir de redes Bayesianas são modeladas por $(D A G) G=(V, E)$, onde as variáveis são os vértices e as arestas identificam as relações entre as variáveis, formando um grafo dirigido e sem ciclos, como mostra a Figura 2.

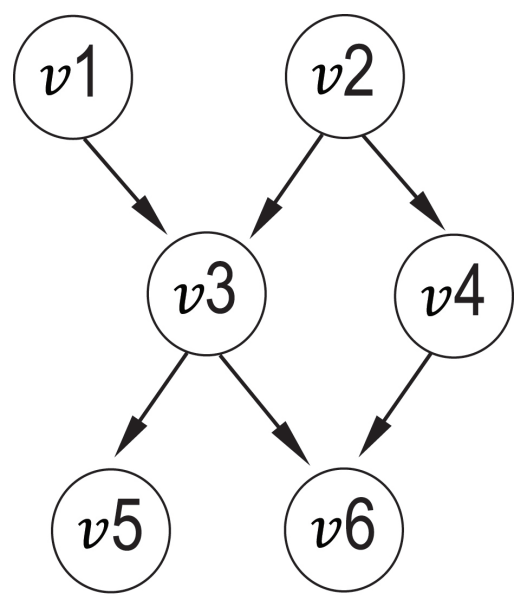

Figura 2: Grafo construído a partir de variáveis $(v)$ e suas relações (indicadas por setas)

Como relatado por Russell e Norvig (1995) o processo geral para construção de uma rede Bayesiana é dado pelo Algoritmo 1. A condição de que os novos vértices devem ser conectados aos antigos, garante que o grafo seja sempre acíclico.

Algumas hipóteses Markovianas são incorporadas às redes Bayesianas, como a determinação de que cada variável $V_{i}$ é independente de outros genes não preditores, dado os seus preditores em $G$ (Dougherty , 2007). Uma distribuição conjunta que satisfaça esta hipótese de Markov pode ser decomposta em um produto das probabilidades condicionais, dado por: 


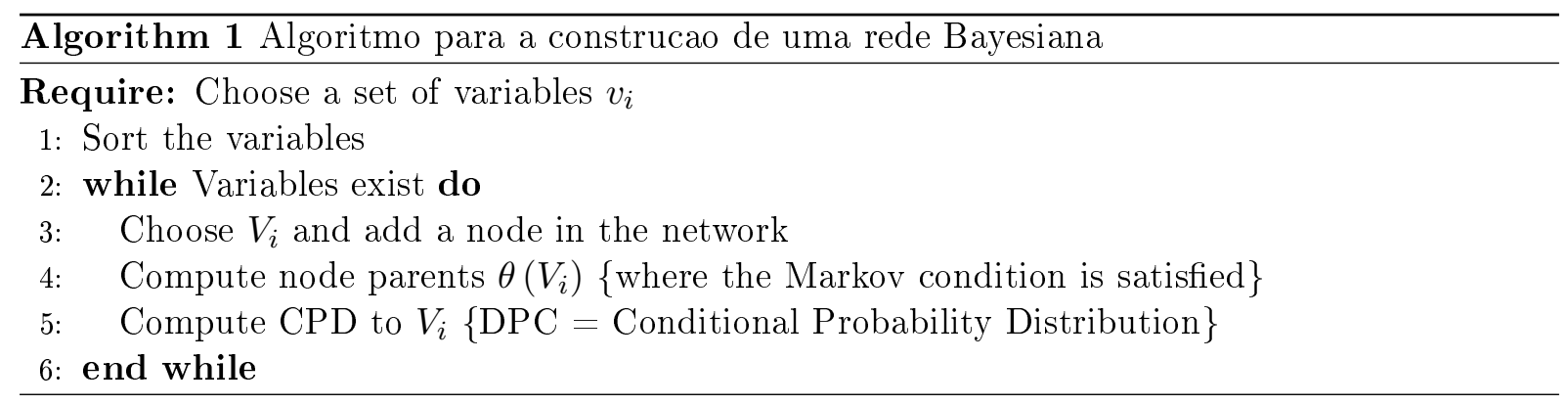

$$
P\left(V_{1}, V_{2}, \ldots, V_{n}\right)=\prod_{i=1}^{N} P\left(V_{i} \mid \text { preditores } V_{i}\right)
$$

A Figura 2 apresenta uma rede Bayesiana com seis vértices, onde o vértice $v 6$ é independente do vértice $v 5$, dado $v 1, v 2, v 3$ e $v 4$. Sendo assim, $P(v 6 v 1, v 2, v 3, v 4, v 5)=P(v 6 v 3, v 4)$. A distribuição conjunta do exemplo da Figura 2 pode ser vista como:

$$
P(v 1, v 2, v 3, v 4, v 5)=P(v 1) P(v 2) P(v 3 \mid v 1, v 2) P(v 4 \mid v 2) P(v 5 \mid v 3) P(v 6 \mid v 3, v 4)
$$

Com a tabela de probabilidade condicional é possível observar as probabilidades de cada vértice dado seus predecessores imediatos. Considerando que o vértice representa um gene, é possível atribuir valor para cada gene como sendo um dos possíveis estados $-1,0$ ou 1, e.g. expressão diminuída, sem alteração ou expressão aumentada, respectivamente. Considerando a equação 2.5, teríamos as entradas como apresentadas na Tabela 2.

Tabela 2: Representação de probabilidades condicionais de um vértice em redes Bayesianas. A probabilidade do vértice $v_{4}$ apresentar expressão aumentada, dado que $v_{2}$ tem expressão diminuída é representada por $P\left(v_{4}=1 \mid v_{2}=-1\right)=0.05$.

\begin{tabular}{cccc}
\hline $\mathrm{v} 2$ & $\mathrm{P}(\mathrm{v} 4=-1 \mid \mathrm{v} 2)$ & $\mathrm{P}(\mathrm{v} 4=0 \mid \mathrm{v} 2)$ & $\mathrm{P}(\mathrm{v} 4=1 \mid \mathrm{v} 2)$ \\
\hline-1 & 0.8 & 0.15 & 0.05 \\
0 & 0.7 & 0.2 & 0.1 \\
1 & 0.6 & 0.3 & 0.1 \\
\hline
\end{tabular}

\subsubsection{Rede em Módulo}

Uma rede em módulo pode ser vista como uma rede Bayesiana em que as variáveis em um mesmo módulo compartilham a mesma entrada e os mesmos parâmetros. Na verdade, modelos probabilísticos que compartilham parâmetros são comuns em uma variedade de aplicações, e também são usados em outras linguagens, tais como redes dinâmicas Bayesianas (Dean e Kanazawa, 1989), redes Bayesianas orientadas a objeto (Koller e Pfeffer , 1997), e modelos relacionais probabilísticos (Friedman et al. , 1999; Koller e Pfeffer , 1998). A razão para o agrupamento dos genes em módulos baseia-se em exemplos biológicos nos quais os mesmos circuitos de regulação coordenam a ativação ou a repressão de grupos de genes que estão envolvidos no mesmo processo, e.g. todo o complexo ribossômico que é regulado por fatores de transcrição comuns (Pe'er , 2005). A Figura 3 mostra um exemplo para explicação das redes em módulos e a distinção de uma rede Bayesiana. 
A

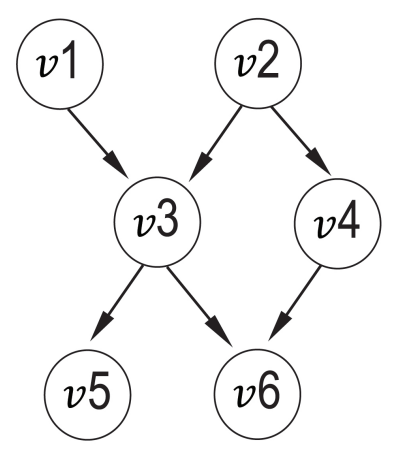

B

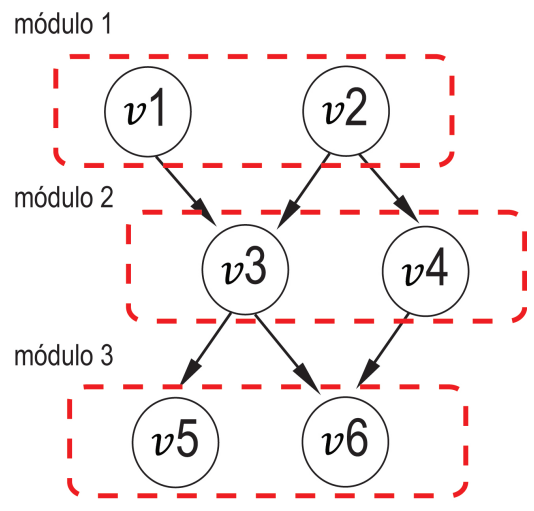

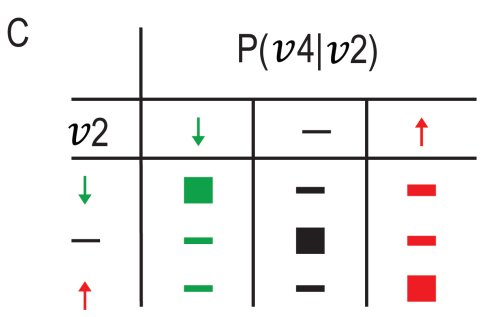

Figura 3: (A) Representação de uma rede Bayesiana onde a distribuição conjunta é $P(v 1, v 2, v 3, v 4, v 5)=$ $P(v 1) P(v 2) P(v 3 \mid v 1, v 2) P(v 4 \mid v 2) P(v 5 \mid v 3) P(v 6 \mid v 3, v 4)$ e cada vértice representa uma distribuição de probabilidade conjunta. (B) Modelo simplificado de redes com três módulos onde o retângulo pontilhado representa a distribuição da probabilidade condicional. Nesse exemplo, o módulo 3 tem a seguinte distribuição: $P($ Modulo3, $v 5, v 6)=P(v 5, v 3)+P(v 6, v 3, v 4)$. (C) Distribuição de probabilidade condicional referente à $P(v 4 v 2)$, e.g. quando $v 2$ têm expressão diminuída, espera-se diminuição na expressão de $v 4$.

A rede Bayesiana da Figura 3 (A) descreve as dependências entre os vértices. Se cada vértice representar um gene com expressão variável, assume-se que para estes genes possam ser atribuídos três possíveis valores: expressão diminuída, expressão inalterada, expressão aumentada. Nesse exemplo, o gene $v 4$ depende do gene $v 2$. A distribuição de probabilidade condicional (DPC) indica que o comportamento do gene $v 4$ é semelhante ao gene $v 2$, i.e., quando a expressão de $v 4$ aumenta, há uma probabilidade aumentada da expressão de $v 2$ também aumentar e vice-versa. Em geral, a rede Bayesiana específica uma DPC para cada alteração da expressão gênica como uma função estocástica dos genes pais. Para modelar este tipo de situação, é possível dividir as variáveis de alteração da expressão gênica em grupos, chamados de módulos, exigindo que as variáveis no mesmo módulo tenham o mesmo modelo probabilístico. Na Figura 3(B) um exemplo com três módulos: genes $v 1$ e $v 2$, genes $v 3$ e $v 4$ e um módulo com os genes $v 5$ e $v 6$. Neste modelo, é preciso especificar apenas três DPCs, uma para cada módulo, uma vez que todas as variáveis de um mesmo módulo compartilham o mesmo DPC. Em comparação, seis diferentes DPCs são necessários para uma representação da rede Bayesiana. Esta noção de um módulo é a idéia-chave subjacente ao formalismo de redes em módulos (Segal et al., 2003). A Figura 4 apresenta distribuição de probabilidade condicional para cada variável atribuída a um módulo e a relação entre os módulos.

A aplicação de modelos probabilísticos pode ser dificultada pelas características das informações utilizadas. Dados de expressão gênica geralmente contém muito ruído e podem ser impróprios para a realização de modelagens quantitativas. Esses ruídos, entre outras razões, são devido à quantidade e qualidade das amostras utilizadas, à eficiência de marcação e ao processamento do sinal pelo scanner. Para isso, frequentemente recorre-se a inclusão de conhecimentos biológicos 


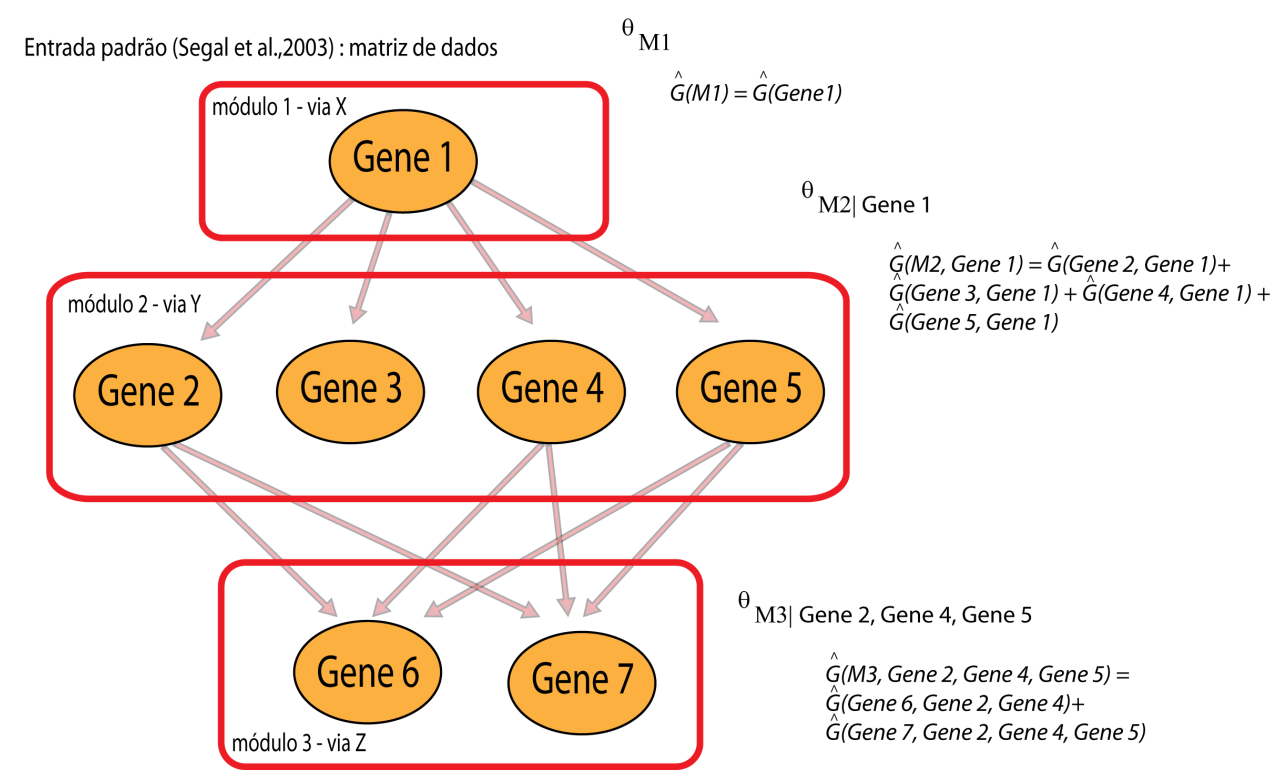

Figura 4: Representação de um modelo de redes em módulos com três instâncias. A distribuição de probabilidade condicional (DPC) de cada módulo é conectada às variáveis atribuídas ao módulo (e.g. $\theta_{M 2} \mid$ Gene1 é conectado a Gene2, Gene3, Gene4 e Gene5). A estatística de cada DPC é a soma das estatísticas de cada variável atribuída ao módulo e seus pais.

a priori. Na tese de Lopes (2011) foi realizada uma descrição detalhada de alguns problemas encontrados para a construção de modelos probabilisticos e modelagem de redes. Um desses problemas é com relação à dimensionalidade dos dados onde há um aumento exponencial da complexidade devido ao aumento de sua dimensionalidade, exigindo um alto custo computacional para o processamento das informações (Bellman e Rand, 1957; Bishop , 1995; Jain et al. , 2000). Para lidar com esse problema é necessária a utilização de técnicas que sejam capazes de encontrar estruturas significativas de baixa dimensão dentro de dados de alta dimensão, como por exemplo, a seleção de características, que tem como objetivo selecionar variáveis importantes, a fim de distinguir ou explicar certos fenômenos. Esse tipo de análise pode ser feita através de softwares, como o DimReduction de Lopes (2011).

\subsubsection{Câncer de Pênis}

O câncer de pênis (CaPe) é uma neoplasia rara nos países desenvolvidos e possui maior incidência nos países em desenvolvimento. Esse tumor corresponde a aproximadamente 10\% das doenças malignas masculinas em alguns países da áfrica, ásia e América do Sul e afeta até 8,3:100.000 homens em certas regiões africanas (Sonpavde et al. , 2013). No Brasil, o CaPe ocorre em 2,9-6,8:100.000 homens, com maiores índices nas regiões Norte e Nordeste (Favorito et al. , 2008). Já nos países desenvolvidos como os da Europa ocidental e Estados Unidos a doença ocorre em 0,3-1,0:100.000 homens e corresponde a 0,4-0,6\% de todas as doenças malignas masculinas (Jemal et al. , 2007; Parkin e Muir , 1992). Segundo dados do NIH (do inglês, National Institute of Health, Estados Unidos) foram identificados em 2012 nos Estados Unidos 1.570 novos casos e 310 mortes de pacientes com CaPe (Sonpavde et al. , 2013).

O CaPe ocorre preferencialmente a partir da sexta década de vida, com incidência dependente da idade que aumenta constantemente e possui um pico ao redor dos 70 anos (Barnholtz-Sloan et al. , 2007). Esses tumores podem ocorrer ocasionalmente em homens mais jovens. No Brasil, $79 \%$ dos 
pacientes com CaPe possuem idade superior a 46 anos e 7,4\% apresentam idade inferior a 35 anos (Favorito et al. , 2008).

Os carcinomas de células escamosas (CEC) compreendem a 95\% dos casos de CaPe. O principal subtipo histológico do CEC é conhecido como usual e está presente em aproximadamente $49 \%$ dos casos. Outros subtipos de CEC incluem condilomatoso (17\%), verrucoso (8\%), papilar (7\%), basalóide (4\%), entre outros, os quais possuem padrões infiltrativos e de crescimento variado (Cubilla et al. , 2004; Eble et al. , 2004). Os casos restantes de CaPe (5\%) podem estar presentes na forma de carcinomas de células de Merkel, carcinoma sebáceo, carcinoma de células basais, entre outros (Eble et al. , 2004).

O conhecimento sobre marcadores genéticos relacionados ao CaPe é extremamente limitado, principalmente quando comparado com outros tipos de carcinomas, tais como tumores cervicais e de cabeça e pescoço. Os relatos em CaPe são geralmente limitados a genes específicos e há raros relatos que utilizaram análise de dados em larga escala (Alves et al. , 2001; Guimaraes et al. , 2011; Kroon et al. , 2008).

O estudo de Guimaraes et al. (2009) revisou o prontuário e material patológico de 333 pacientes com carcinoma de pênis invasivo, tratados cirurgicamente, e identificou maior grau histológico e invasão vascular e perineural em casos de carcinoma sarcomatóide, basalóide e adenoescamoso, correlacionando-se com uma maior taxa de metástase nodal e mortalidade. Estas características foram incomuns em casos de carcinoma verrucoso e papilífero.

A rara incidência dessa doença contribui para a ausência de métodos padronizados para o tratamento dos pacientes. Quando o tumor é diagnosticado em fases iniciais (estádios I-II), é observada uma evolução favorável, com a maioria dos pacientes sendo considerada como curada da doença. A ressecção cirúrgica é a principal forma de tratamento, sendo direcionada tanto para o tumor primário quanto para os nódulos linfáticos regionais. A linfadenectomia é frequentemente associada com um alto risco de complicações como infecção, necrose, linfedema e aumento da mortalidade. O diagnóstico preciso do comprometimento linfonodal e a detecção de marcadores confiáveis para a ocorrência de metástases pode resultar em um grande benefício para esses pacientes (Ficarra et al. , 2002; Horenblas , 2001). O procedimento cirúrgico ideal deve eliminar a doença e preservar as funções sexuais e urinárias. Entretanto, isso nem sempre é possível devido à extensão da doença. Alguns pacientes são submetidos a procedimentos radicais, principalmente a penectomia total, que pode afetar psicologicamente estes indivíduos. Como alternativas de tratamento, têm sido amplamente utilizada a cirurgia controlada microscopicamente, terapia a laser, radioterapia, braquiterapia, entre outros (Kuasne et al. , 2013; Mosconi et al. , 2005).

\subsection{Aspectos Relacionados ao Papilomavírus Humano (HPV)}

Os HPV correspondem a vírus pequenos de DNA em dupla fita que pertencem à família Papillomaviridae (de Villiers et al. , 2004). Foram descritos mais de 100 tipos de HPV associados principalmente a infecções no trato genital. Alguns genótipos virais estão envolvidos em mecanismos carcinogênicos, os chamados HPV de alto risco (HPV16, 18, 31, 35, 39, 45, 51, 52, $56,59,66,68,69,73$ e 82), enquanto outros praticamente não possuem envolvimento com câncer e são chamados HPV de baixo risco (HPV 6, 11, 40, 42, 43, 44, 54, 61, 70, 72, 81 e CP6108) (Shukla et al. , 2009).

Apesar da relação causal bem estabelecida entre a infecção pelo HPV e o desenvolvimento 
de câncer cervical demonstrada por estudos epidemiológicos e moleculares, apenas uma fraca relação é observada entre o vírus e outros tipos de carcinomas, tais como câncer de vulva, ânus e pênis (zur Hausen, 2009).

Estudos demonstram a presença de HPV, principalmente os subtipos 16 e 18, em 40 a $50 \%$ dos casos de câncer de pênis (Guimaraes et al. , 2011; Miralles-Guri et al. , 2009). Os CECs de pênis dos subtipos basalóide ou condilomatoso possuem maior associação com a presença de HPV de alto risco, o que pode ser observado em 70 a $100 \%$ dos casos e torna a relação etiológica entre HPV e CaPe mais plausível (Cubilla et al. , 1998; Rubin et al. , 2001).

O genoma do HPV pode ser dividido em três domínios: uma URR (do inglês Upstream Regulatory Region) não-codificante, uma região precoce com as ORFs (do inglês Open Reading Frames) E6, E7, E1, E2, E4 e E5 e uma região tardia contendo os genes L1 e L2, responsáveis por codificar proteínas do capsídeo. Embora ainda não esteja completamente elucidado para $\mathrm{CaPe}$, o mecanismo de indução e promoção tumoral causado pelo HPV parece ser semelhante ao que ocorre para o carcinoma do colo uterino. Neste caso, as proteínas E6 e E7 mostram expressão aumentada quando o DNA viral se incorpora ao genoma humano. As oncoproteínas E6 e E7 antagonizam as proteínas supressoras de tumor p53 e Rb humanas, respectivamente, o que leva a alterações nas vias $p 14 A R F / M D M 2 / T P 53$ e $p 16 I N K 4 a /$ ciclinaD/RB1 e interfere no controle da divisão celular e apoptose (Sarkar et al. , 1992; zur Hausen , 2009). A inativação de RB1 pela proteína E7 do vírus resulta em uma expressão elevada de p16INK4a, de forma que altas quantidades dessa proteína vêm sendo utilizadas como marcadores de envolvimento viral em alguns carcinomas (Hwang e Shroyer , 2012).

A integração do DNA viral ao genoma do hospedeiro é amplamente relatada em carcinomas, principalmente em tumores da região cervical, sendo um evento crucial na oncogênese (Dall et al. , 2008; Jeon e Lambert , 1995; Kalantari et al. , 2001). Esta integração pode levar tanto a ativação como a inativação de genes envolvidos no processo tumoral. Acredita-se ainda que alterações genéticas e epigenéticas subsequentes à integração do HPV estejam envolvidas na carcinogênese relacionada ao vírus em CaPe. Leis et al. (1998) avaliaram a presença de HPV e mutações nos genes TP53 e HRAS em um CEC de pênis e duas metástases inguinais desenvolvidas pelo mesmo paciente 5 e 7 anos após a cirurgia para retirada do tumor primário. Foi observada infecção por HPV18 no tumor primário e nas duas metástases e alterações em HRAS somente no tecido com desenvolvimento de metástase sete anos após a retirada do tumor primário. A presença de mutações em $H R A S$ somente na segunda metástase do paciente sugere que a ativação desse gene corresponde a um evento tardio na progressão maligna associada ao HPV18 em CEC de pênis.

A maioria dos dados em literatura em que é analisada a presença do HPV em CaPe está relacionada a estudos de prevalência, genotipagem viral e correlação com características clínicas e patológicas, tais como tipo histológico, grau de diferenciação do tumor, presença de metástases em linfonodos, entre outras.

Segundo o estudo de Backes et al. (2009) foi relatado que pacientes com CEC peniano tinham uma prevalência de HPV que variava de 39,7\% na América do Sul a 59,3\% na ásia. Quatro tipos predominantes de HPV foram encontrados: HPV16 (30,8\%), HPV6 (6,7\%), HPV18 (6,6\%) e HPV5 (5,6\%). As outras formas de HPV estudadas apresentaram uma prevalência inferior a 2\%. Foi observada maior prevalência do HPV16 em indivíduos residentes na América do Norte 
(39.4\%), Europa (32,9\%) e América do Sul (20,3\%), enquanto o HPV6 foi mais prevalente na ásia $(35,9 \%)$.

A influência prognóstica da infecção pelo HPV em pacientes com CaPe ainda é controversa. Em um estudo realizado por Gregoire et al. (1995), o DNA de HPV foi detectado com maior frequência em pacientes com tumores de pênis mais agressivos, os quais possuíam maior infiltração e elevado grau tumoral, enquanto Bezerra et al. (2001) encontraram DNA do vírus com maior abundância em tumores de grau histológico I. Não foi reportada qualquer associação entre a presença do vírus e metástases linfonodais ou sobrevida e os dados desses autores sugeriram não haver qualquer valor prognóstico para infecção pelo HPV em pacientes com CaPe. Entretanto, Lont et al. (2006) indicaram um aumento na sobrevida de pacientes com CaPe portadores de HPV quando comparados a pacientes onde o vírus estava ausente. Segundo os autores, a sobrevida aumentada desses indivíduos deve estar associada a um menor número de alterações genéticas na presença do vírus, semelhante ao observado em CEC de cabeça e pescoço. Atualmente há duas vacinas profiláticas contra HPV, sendo uma bivalente (HPV16/18), com aprovação do FDA (Food and Drug Administration) em 2009 para prevenção de carcinoma cervical em mulheres de 10-25 anos, e outra quadrivalente (HPV16/18/6/11), aprovada em 2006 e 2009 pelo FDA para uso em mulheres e contra verrugas genitais em homens, respectivamente. Embora a indicação masculina da vacina seja relacionada à prevenção de verrugas genitais, acredita-se que carcinomas do ânus, pênis e de orofaringe possam também ser combatidos (Chung et al. , 2013; Tisi et al. , 2013; Turner et al. , 2013). Apesar dos dados serem promissores, a eficácia da vacina para homens foi avaliada somente quanto a presença de verrugas genitais, e dados relativos ao desenvolvimento de tumores ainda não estão disponíveis. 


\section{JUSTIFICATIVA}

O desenvolvimento de metodologias de integração de dados é de grande importância devido ao aumento contínuo de dados públicos, assim como a evolução tecnológica que permite a produção e obtenção de um número cada vez maior de informações. As metodologias e ferramentas existentes, raramente levam em consideração alguns detalhes importantes sobre as alterações genéticas, e.g. a diferença entre deleções homozigótica e heterozigóticas, ganhos de cópias e amplificação do DNA, ou então a diferenciação entre genes drivers e passengers. O presente estudo contribui com uma metodologia para a integração de quatro níveis de alterações utilizando 31 amostras de carcinoma de pênis: alteração do número de cópias do DNA, metilação de ilhas CpGs, expressão de miRNA e expressão de transcritos codificadores. É importante destacar que a utilização de metodologias para integração de diferentes níveis de informações sobre o mesmo paciente ainda é limitada e, de acordo com o nosso conhecimento, não há relatos na literatura sobre metodologias para integração de quatro fontes de dados nesse tipo de carcinoma.

Outra contribuição desse estudo é a apresentação de uma metodologia para seleção de genes candidatos. A seleção desses genes para subsequente utilização em algoritmos de predição ou inferência é fundamental, pois todo o processo subsequente depende da lista de genes alvo utilizada como entrada. Entretanto, é necessário superar algumas dificuldades decorrentes da correlação de diferentes fontes de dados devido [̄a]s características peculiares de cada alteração. Por esta razão, assume-se nesse trabalho que a utilização de pesos para determinadas características dos genes pode ser um mecanismo eficiente de seleção de candidatos a driver.

Também é apresentada uma adaptação das redes em módulos com a inclusão de passengers e interação proteína-proteína (PPI) como critérios para seleção de módulos. Segundo McFarland et al. (2013), o acúmulo de passengers em uma via biológica pode alterar o curso da progressão tumoral. Esse relato aumenta a relevância da abordagem aqui utilizada uma vez que a associação de genes passengers com um conjunto de genes co-expressos (módulos) pode contribuir para a identificação de vias biológicas relevantes para o desenvolvimento do carcinoma de pênis e auxiliar na escolha de genes candidatos a drivers como futuros biomarcadores para a doença. Ainda, foram discutidos mecanismos para resolução de problemas importantes durante a etapa de inferência. Determinar que a expressão do gene A é responsável pela alteração da expressão de um módulo $M$ de genes co-expressos pode ser um equívoco, uma vez que processos de metilação e miRNA podem ser mecanismos celulares para recompor uma atividade em uma via específica ou então decorrente da ação da doença na célula. O acúmulo dessas alterações pode ser um importante aliado na mudança no percurso da via na célula. Além disso, determinar que o módulo $M$ seja diretamente alterado pelo gene regulador A sem que ocorra uma interação entre os genes desse módulo pode resultar na escolha de módulos pouco representativos para o desenvolvimento tumoral.

Além do desenvolvimento desta metodologia na área da bioinformática, destaca-se o tipo tumoral escolhido. O conhecimento das alterações genéticas relacionadas ao desenvolvimento de câncer de pênis é bem limitado, devido principalmente a sua rara incidência. Entretanto, o tratamento por procedimento cirúrgico, processo mais frequentemente utilizado para controle local da 
doença, pode levar a amputação parcial ou total do órgão, com subsequente morbidade psicossexual. Assim, a caracterização genética destes tumores é de extrema importância para aumentar o conhecimento da biologia da doença na tentativa de desvendar marcadores moleculares e de alvos terapêuticos, minimizando as consequências físicas, sexuais e psicológicas que são geradas nestes pacientes.

Estudos recentes avaliaram duas vias para o desenvolvimento do $\mathrm{CaPe}$ : uma relacionada ao HPV e outra independente do vírus. Por isso, a metodologia proposta também estudou genes alterados obtidos da comparação entre amostras positivas e negativas para a infecção pelo vírus, contribuindo para uma caracterização maior da influência do vírus no desenvolvimento desse tumor. Para o nosso conhecimento, até o momento, há apenas um relato em literatura que descreve a análise molecular, utilizando a metodologia de microarray para avaliar 56 casos de CaPe (Kroon et al. , 2008), ressaltando a importância do estudo proposto nessa tese. 


\section{OBJETIVOS}

\subsection{Objetivo Geral}

Desenvolver uma nova metodologia para integração de dados obtidos pelas análises de alterações genômica, expressão de transcritos codificadores, metilação de ilhas CpGs e expressão de miRNA em amostras de carcinoma de pênis para a identificação de genes drivers que possam ser determinantes para o desenvolvimento tumoral.

\subsection{Objetivos Específicos}

- Selecionar genes candidatos a drivers de acordo com a melhor combinação entre os diferentes níveis de alteração;

- Utilizar genes passengers e interações proteína-proteína como mecanismo adicional para formação de módulos com maior potencial de associação com o desenvolvimento do carcinoma de pênis;

- Enriquecer os módulos formados para a identificação de vias biológicas relevantes para o desenvolvimento do carcinoma de pênis e associar os candidatos a driver preditos como reguladores do conjunto de genes co-expressos;

- Aplicar o método de integração de dados em dois estudos: alterações obtidas pela comparação entre amostras tumorais e normais de CaPe e estudo das alterações obtidas entre amostras positivas e negativas para a infecção pelo HPV;

- Validar in sílico (meta-análise) e in situ (RT-qPCR, qPCR e pirosequenciamento) a metodologia de integração de dados e algoritmo de redes em módulos. 


\section{MATERIAIS E MÉTODOS}

\subsection{Casuística}

Foram utilizadas 31 amostras armazenadas a -80C de carcinomas de pênis usuais provenientes do Banco de Tumores do AC Camargo Cancer Center - SP (11 casos) e Hospital do Câncer de Barretos - SP (20 casos) sendo que 13 casos são positivos para a infecção pelo HPV de alto risco, 16 e 18. Os critérios de inclusão compreendem os casos com tecidos disponíveis para todas as técnicas propostas nesse projeto e ausência de tratamentos quimio ou radioterápico prévios. Os critérios de exclusão incluem os casos que não se adequaram aos critérios acima mencionados. Estas amostras foram coletadas após obtenção do Termo de Consentimento Livre e Esclarecido de todos os pacientes e aprovação do presente projeto pelo Comitê de Ética do AC Camargo Cancer Center (Processo 1230/2009) e do Hospital do Câncer de Barretos (Processo 363/2010). As alíquotas de ácidos nucléicos foram obtidas do Banco de Biomoléculas de ambas as Instituições.

Os dados não processados de aCGH e microarrays de expressão fazem parte da tese de doutorado de Ariane Fidelis Busso. Os experimentos referentes ao perfil epigenômico e miRNA fazem parte da tese de doutorado de Hellen Kuasne. Estes projetos são de responsabilidade da Dra. Silvia Regina Rogatto.

\subsection{Metodologia para Integração de Dados}

Neste estudo foram avaliadas as alterações do número de cópias do DNA, metilação de ilhas CpGs, expressão de transcritos codificadores (mRNA) e expressão de miRNAs. Foi realizada a comparação entre amostras tumorais e normais e positivas e negativas para a infecção pelo HPV.

A metodologia foi dividida em duas etapas: (1) seleção a priori de genes a partir das quatro plataformas utilizadas e (2) utilização dos genes selecionados na primeira etapa como alvos durante a inferência de redes em módulos. Posteriormente os candidatos selecionados foram anotados e avaliados de acordo com a associação com vias toxicológicas, predição de reguladores, alvos de drogas e medidas topológicas. Mais especificamente, a primeira etapa tem como objetivo a identificação de genes-alvos possivelmente relacionados ao desenvolvimento do tumor e que apresentam associações estatisticamente significantes de acordo com os parâmetros estabelecidos. Posteriormente, os genes que não foram pré-selecionados na primeira etapa foram utilizados como possíveis passengers e juntamente com interações proteína-proteína (obtidas a partir de bancos de dados públicos de interação) foram utilizados como um mecanismo adicional de seleção de módulos. Essa etapa é descrita detalhadamente no tópico Redes em Módulos (Materiais e Métodos). A Figura 5 apresenta todos os processos relacionados com a seleção dos alvos nesse estudo. 


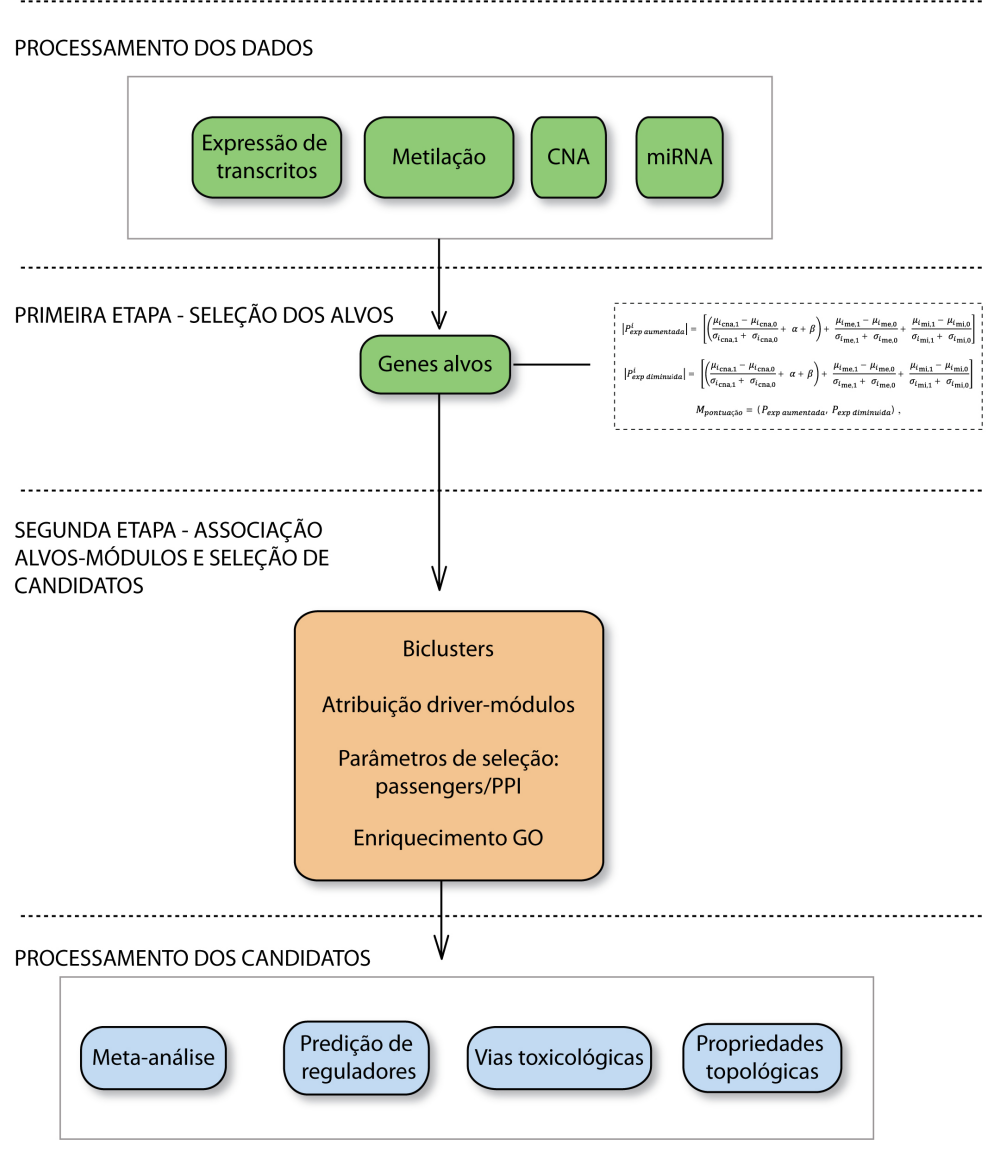

Figura 5: Fluxograma com as etapas de seleção dos genes candidatos à drivers.

\subsubsection{Primeira Etapa - Pré-Seleção de Genes}

As matrizes utilizadas neste estudo foram representadas por $m \times n$, onde $m$ representa o número de genes e $n$ o número de amostras em cada um dos níveis de alteração. Os dados foram organizados sob a forma de matrizes para alteração de cópias genômicas $\left(M_{\text {cna }}\right)$, expressão de transcritos codificadores $\left(M_{e x}\right)$, metilação $\left(M_{m e}\right)$ e expressão de miRNAs $\left(M_{m i}\right)$. Detalhadamente, os conjunto de alterações foram descritos a seguir.

\section{Analise de Expressão de Transcritos Codificadores por Microarray}

Os dados de microarray de expressão foram representados como uma matriz $M_{e x}=\left(A_{e x}, G_{e x}\right)$, onde $A_{e x}=\left\{a_{1}, a_{2}, a_{3}, \ldots, a_{n}\right\}$ é o conjunto finito de amostras e $G_{e x}=\left\{g_{1}, g_{2}, g_{3}, \ldots, g_{m}\right\}$ é o conjunto finito de genes. Os valores estão em $\log _{2}$, onde $G_{e x}=\{g \in \mathbb{R} \mid-\infty<g<\infty\}$.

\section{Analise de Metilação por Microarray}

Os dados de metilação foram representados por $M_{m e}=\left(A_{m e}, G_{m e}\right)$, sendo $A_{m e}=\left\{a_{1}, a_{2}, a_{3}, \ldots, a_{n}\right\}$ o conjunto finito de amostras e $G_{m e}=\left\{g_{1}, g_{2}, g_{3}, \ldots, g_{m}\right\}$ o conjunto finito de genes. Os dados também foram representados por $\log _{2}$ para caracterização de sondas hipermetiladas e hipometiladas. Nessa matriz, $G_{m e}=\{g \in \mathbb{R} \mid-\infty<g<\infty\}$. 


\section{Alteração de Cópias Genômicas}

Nessa etapa os dados de CNA foram separados em três partes: (1) matriz mxn, representada por $M_{\text {cna }}=\left(A_{\text {cna }}, G_{c n a}\right)$, onde $A_{c n a}=\left\{a_{1}, a_{2}, a_{3}, \ldots, a_{n}\right\}$ é o conjunto finito de amostras e $G_{c n a}=\left\{g_{1}, g_{2}, g_{3}, \ldots, g_{m}\right\}$ representa o conjunto de genes, (2) matriz com valores discretizados, sendo $G_{c n a}=\{g \in \mathbb{Z} \mid-1 \leq g \leq 1\}$ representado por $\beta$ e englobando deleções homozigóticas e amplificações e (3) matriz com genes dispostos em linhas e classificação das CNVs como "raras", "novas" ou "comuns" em colunas, sendo representada por $\alpha$.

\section{Expressão de miRNA}

Os dados de expressão de miRNA foram representados como $M_{m i}=\left(A_{m i}, G_{m i}\right)$, onde $A_{m i}=$ $\left\{a_{1}, a_{2}, a_{3}, \ldots, a_{n}\right\}$ é o conjunto finito de amostras e $G_{m i}=\left\{g_{1}, g_{2}, g_{3}, \ldots, g_{m}\right\}$ o conjunto de miRNAs. Os valores foram apresentados como $\log _{2}$.

\section{Pontuação}

Para a identificação das pontuações entre os diferentes níveis de alterações, primeiramente foi feita uma correlação para cada gene $g_{i}$ entre pares de plataformas: $\operatorname{Cor}\left(M_{c n a}, M_{e x}\right), \operatorname{Cor}\left(M_{m e}, M_{e x}\right)$ e $\operatorname{Cor}\left(M_{m i}, M_{e x}\right)$, considerando $r_{(x, y)}>0,3$ para correlação entre CNA e expressão gênica, e $r_{(x, y)}<-0,3$ entre metilação e expressão de mRNA e miRNA e expressão de mRNA. Posteriormente foi utilizada a razão entre sinal e ruído (SNR, do inglês Signal-to-noise ratio) para avaliar as alterações encontradas percorrendo as 31 amostras da matriz de expressão gênica onde os dados foram interpretados como: alterados (1) e sem alteração (0), tanto para expressão aumentada, quanto para expressão diminuída. Considera-se $\mu_{c n a, 1}^{i}$ e $\sigma_{c n a, 1}^{i}$ como sendo a média e desvio padrão, respectivamente, da expressão gênica quando $g_{c n a}$ for igual a 1 e $\mu_{c n a, 0}^{i}$ e $\sigma_{c n a, 0}^{i}$ como sendo a média e desvio padrão da expressão gênica quando $g_{c n a}$ for igual a 0 . Os valores $\mu_{m e, 1}^{i}$ e $\sigma_{m e, 1}^{i}$ são calculados similarmente a partir da matriz $M_{m e}$ para metilação. Para o $i$-th gene foi calculado a pontuação entre as alterações de CNA, metilação, miRNA e os valores médios obtidos na matriz de expressão de mRNA. Considerando os critérios anteriores,

$$
\begin{gathered}
\left|P_{\text {exp-aumentada }}^{i}\right|=\left[\left(\frac{\mu_{i_{\text {cna }, 1}}-\mu_{i_{\text {cna }, 0}}}{\sigma_{i_{\text {cna }, 1}}+\sigma_{i_{\text {cna }, 0}}}+\alpha+\beta\right)+\frac{\mu_{i_{m e, 1}}-\mu_{i_{m e, 0}}}{\sigma_{i_{m e, 1}}+\sigma_{i_{m e}, 0}}+\frac{\mu_{i_{m i, 1}}-\mu_{i_{m i, 0}}}{\sigma_{i_{m i, 1}}+\sigma_{i_{m i, 0}}}\right] \\
\left|P_{\text {exp-diminuida }}^{i}\right|=\left[\left(\frac{\mu_{i_{\text {cna }, 1}}-\mu_{i_{c n a}, 0}}{\sigma_{i_{\text {cna }, 1}}+\sigma_{i_{\text {cna }, 0}}}+\alpha+\beta\right)+\frac{\mu_{i_{m e, 1}}-\mu_{i_{m e}, 0}}{\sigma_{i_{m e, 1}}+\sigma_{i_{m e}, 0}}+\frac{\mu_{i_{m i, 1}}-\mu_{i_{m i, 0}}}{\sigma_{i_{m i, 1}}+\sigma_{i_{m i, 0}}}\right] \\
M_{\text {pontuacao }}=\left(P_{\text {exp-aumentada }}, P_{\text {exp-diminuida }}\right)
\end{gathered}
$$

onde $\sigma_{m e, 1}^{i}, \sigma_{m i, 1}^{i}, \sigma_{c n a, 1}^{i}>0, \sigma_{m e, 0}^{i}, \sigma_{m i, 0}^{i}, \sigma_{c n a, 0}^{i}>0, P^{i}$ é o peso atribuído para cada gene com expressão aumentada e expressão diminuída de acordo com os demais conjuntos de alterações, $\alpha$ representa a classificação de $x$ como uma variante rara ou nova, $\beta$ classifica o gene

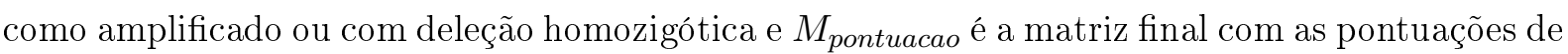
todos os genes selecionados, e apresentados por ordem crescente de pontuação. O pseudocódigo 
foi apresentado no Algoritmo 2.

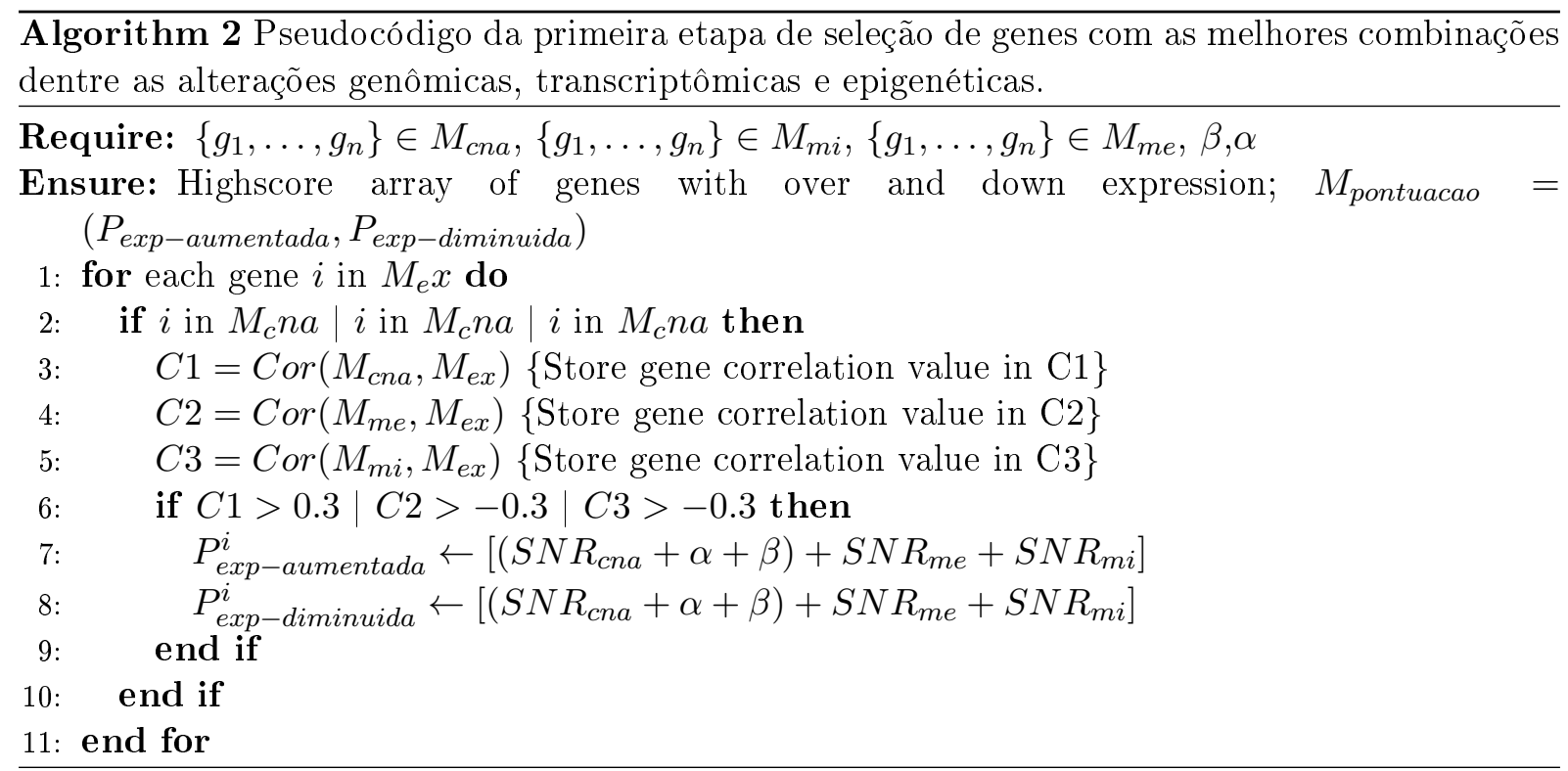

\subsubsection{Redes em Módulos}

No presente estudo foi implementado o método descrito por Michoel et al. (2007) e Segal et al. (2003), com algumas alterações durante a formação, seleção e atribuição de módulos aos genes selecionados na primeira etapa de integração de dados. Aqui, para cada gene $g$, foi associada uma variável randômica $X_{g}$ que assume valores contínuos e corresponde ao nível de expressão genica. A distribuição de $X_{g}$ depende do nível de expressão do conjunto de genes reguladores $R_{g}$ obtidos na primeira etapa de integração de dados.

Nessa etapa da metodologia foram considerados três componentes: (1) partição dos genes da $M_{e x}$ em um conjunto de módulos $M_{z}=1, \ldots, N$ (no presente estudo foi utilizada a biclusterização Bayesiana); (2) estrutura $E$ que atribui para cada módulo $M_{z}$ um conjunto de pais $R$, chamados de reguladores dos genes em $M_{z} ;(\mathbf{3})$ probabilidade condicional (entre módulos e reguladores) para todas as associações que especifica a distribuição sobre os valores de um gene na matriz para cada valor atribuído ao conjunto de reguladores $\left(R_{M_{z}}\right)$. As três etapas apresentadas descrevem a distribuição sobre todos os genes em na matriz de expressão gênica, onde cada gene é dependente dos reguladores do módulo que ele pertence. Aqui, um regulador equivale a um candidato a driver. Posteriormente foi realizado o enriquecimento dos módulos em vias biológicas $(p<0,05)$ e classificação dos genes como: oncogenes, supressores tumorais e fatores de transcrição.

Mais especificamente, se uma rede em módulo for descrita como acíclica (em um desenho com arestas diretas entre genes reguladores e genes co-expressos da matriz) é possível definir uma distribuição de probabilidade conjunta para os niveis de expressão de todos os genes como um produto de uma distribuição condicional,

$$
p\left(g_{1}, g_{2}, g_{3}, \ldots, g_{n}\right)=\prod_{m=1}^{n} p\left(g_{m} \mid g_{n}\right)
$$

No contexto original de redes em módulos assume-se que os genes possam ser agrupados em 
diferentes módulos, onde aqueles que pertencem ao mesmo módulo compartilham os mesmos parâmetros de DPC (Distribuição de Probabilidade Condicional), e podem ser representados pela formação de $M_{z}=\{1, \ldots, z\}$ módulos, uma coleção de genes reguladores para cada módulo $\left(R_{M_{z}}\right)$, e uma distribuição de probabilidade conjunta. A DPC do nível de expressão do gene no módulo $z$ é normal com média $(\mu)$ e desvio padrão $(\sigma)$ dependendo do valor de expressão dos genes reguladores dos módulos obtidos através de uma árvore de regressão. As etapas para implementação e adaptação da rede em módulo utilizada no presente estudo são apresentadas a seguir.

\subsubsection{Biclusterização Bayesiana - Formação dos Módulos}

O processo de formação dos módulos a partir da matriz de expressão gênica tem os níveis de expressão dos genes $(g)$ medidos através de uma variável aleatória $X_{g}$. Considerando uma matriz com os valores de expressão representados por $M_{e x},=g_{1}, g_{2}, g_{3}, \ldots, g_{m}, m \times n$, onde $m$ representa o gene e $n$ as amostras, Segal et al. (2003) sugere um modelo onde $M_{z}$ é definido como um subconjunto de genes com uma partição $\gamma_{z}$ do conjunto $1, \ldots, z$ de módulos. A probabilidade à posteriori para o conjunto de módulos $\left(M_{G_{z}}, \gamma_{Z}\right)$, chamada de $P$, é dada por

$$
P=\prod_{z} \prod_{E \in \gamma_{z}} \iint \mathrm{d} \mu \mathrm{d} \varphi p(\mu, \varphi) \prod_{g \in M_{z}}^{M} \prod_{m \in E}^{K} p(g \mid \mu, \varphi)
$$

onde $p(g \mid \mu, \sigma)$ é a distribuição normal com média $\mu$ e precisão $\varphi$ e $p(\mu, \varphi)$ é a distribuição gama-normal apresentada no estudo de Segal et al. (2005), implementado no presente estudo. Nessa etapa foi utilizado o método de bootstrap para reamostrar os módulos com melhor pontuação a partir da distribuição à posteriori. A Figura 6 apresenta o modelo gráfico de um bicluster e atribuição de reguladores. 


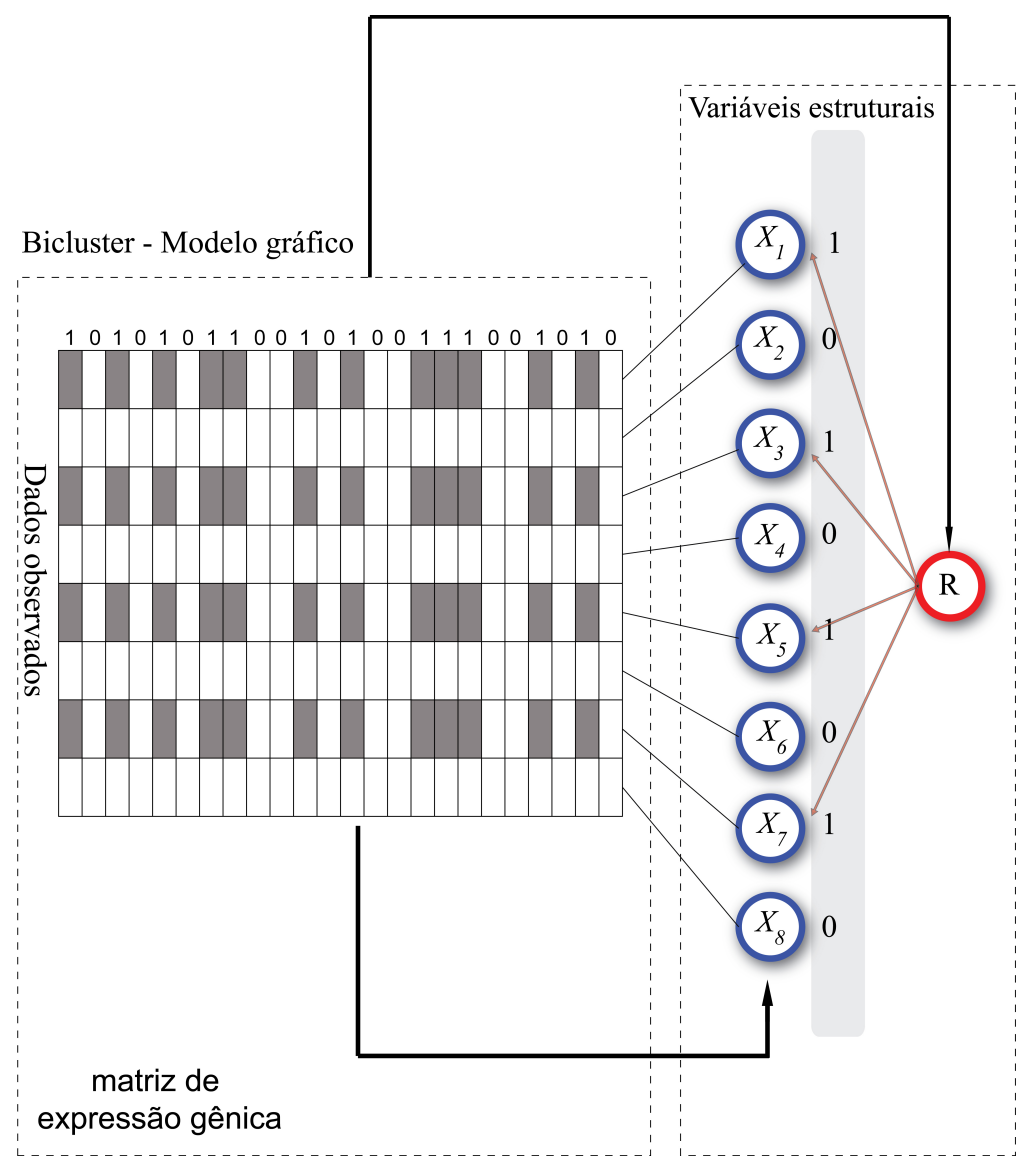

Figura 6: Modelo gráfico de um bicluster para genes e amostras dado uma matriz de expressão gênica e um candidato a regulador.

Mais especificamente, a identificação de módulos de genes começa a partir do primeiro elemento da matriz de expressão e o valor que representa a similaridade entre linhas e colunas para identificar módulos consistentes é calculado com $\beta_{\text {pont }}=\left|\left(b_{i_{1}, j_{1}}+b_{i_{2}, j_{2}}\right)-\left(b_{i_{1}, j_{2}}+b_{i_{2}, j_{1}}\right)\right|$, onde $i_{1}$ e $i_{2}$ são linhas do módulo e $j_{1}$ e $j_{2}$ são colunas do módulo (Kanungo et al. , 2011). Essa técnica é baseada em um modelo aditivo e, portanto pode extrair módulos consistentes da matriz. Durante o processo, linhas e colunas são adicionadas ao módulo de acordo com o limiar $\beta_{\text {pont }}<\beta$ e quando chega ao fim da matriz de expressão e o número de linhas e colunas satisfazem as condições o módulo é armazenado em $M_{z}$.

\subsubsection{Associação entre Genes Pré-selecionados e Módulos}

Para a atribuição dos genes selecionados na primeira etapa de integração de dados como reguladores $(r)$ dos módulos $(z)$ formados foi considerado um conjunto de situações e valores de expressão esperados para cada situação, representado pela expressão de um pequeno conjunto de genes candidatos a reguladores que influenciam a expressão de um módulo. Este conjunto de situações é organizado como uma árvore de regressão composta por dois blocos de construção: "nós" de decisão e "nós" folha. Esse modelo é amplamente utilizado em diversas áreas (Friedman e Meulman , 2003; Marshall , 2001; Robinson , 2008). Cada nó de decisão contém um teste num atributo, corresponde a um candidato, possui uma pergunta sobre seu perfil na matriz de expressão gênica $\left(M_{e x}\right)$ e apresenta dois atributos $\left(y_{\theta}\right)$ : nó da direita (escolhido quando a resposta é verdadeira) e nó da esquerda (quando a resposta é falsa). Para o conjunto de amostras 
utilizadas no estudo, a análise começa na raiz e percorre um caminho dependente da resposta obtida, até que um nó folha seja alcançado e o limiar pré-definido seja atingido. Cada folha está associada a uma classe e apresenta uma distribuição de probabilidade que representa a expressão dos genes do módulo $M_{z}$. As expressões dos genes em $M_{z}$, para cada situação, são analisadas como uma distribuição normal, com média e variância armazenadas na folha correspondente. Um exemplo foi apresentado na Figura 7, com uma árvore de regressão com genes presentes em módulos enriquecidos para o ciclo celular.

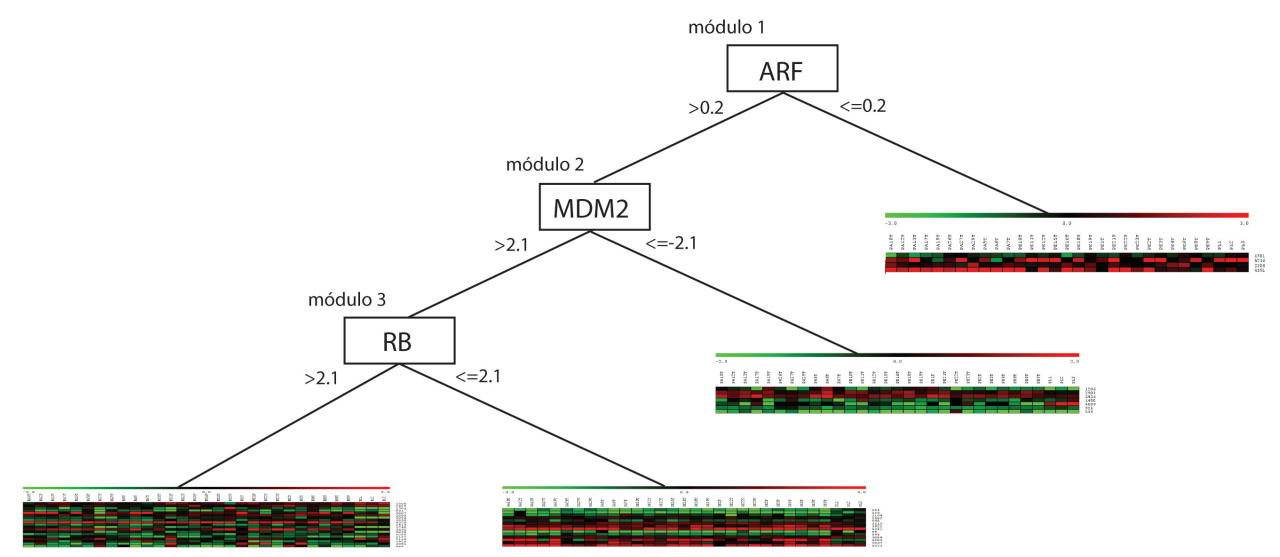

Figura 7: Modelo de árvore de regressão com genes enriquecidos para via do ciclo celular. Cada nó (gene) possui dois blocos de decisão acompanhados por um modelo linear. Através de um limiar pré-definido a análise percorre toda a árvore, partindo da raiz até a folha.

Nesse caso a probabilidade de se observar alguns valores de expressão para o gene no array é definida pela distribuição normal específica para um determinado comportamento. Em uma situação onde o valor de expressão do gene é fortemente regulado por um candidato a driver, a distribuição normal pode ter uma variância muito pequena. Para cada conjunto de amostras $N$ na partição $z$ para um dado módulo $z$, uma distribuição normal é associada aos parâmetros $\left(\mu_{N}\right.$, $\left.\varphi_{N}\right)$ que podem ser estimados a partir da distribuição posterior. Essa etapa é responsável pela predição do perfil de alteração de uma condição $(N)$, dado o nível de expressão de um conjunto de $R_{z}$ genes candidatos, ou seja, há uma distribuição condicional,

$$
p\left(x_{g} \mid x_{r}\right)=p\left(x_{g} \mid \mu_{N}, \varphi_{N}\right)
$$

A escolha de um perfil é feita pela utilização da árvore de regressão. Para cada nó $\theta$, foi associado um regulador $r_{\theta}$ e um valor de partição $\gamma$. A decisão do nó é baseada no teste $g_{r_{\theta}} \geq z_{\theta}$ ou $g_{r_{\theta}}<z_{\theta}$. Posteriormente é utilizada a árvore de regressão com o sorteio dos perfis de expressão $N \in \gamma_{z}$ pela média $\mu_{N}$, ligando o conjunto de dados ordenados hierarquicamente. Foi definido que cada nó da árvore seria associado à atributos representados por:

$$
y_{\theta}= \pm 1 \begin{cases}y_{\theta}=-1 & \text { expressao diminuida } \\ y_{\theta}=1 & \text { expressao aumentada }\end{cases}
$$

onde $y_{\theta}=-1$ define a escolha pelo perfil de expressão diminuída (lado esquerdo da árvore) e $y_{\theta}=1$ define a escolha pelo perfil de expressão aumentada (lado direito da árvore).

O gene candidato obtido na primeira etapa de integração de dados, representado por $r_{\theta}$ foi então associado ao valor da direção da escolha do nó $\theta$ com uma probabilidade condicional 
definida por $p\left(y_{\theta} \mid g_{r_{\theta}}, z_{\theta}, \beta_{\theta}\right)=1+e^{-\beta_{\theta} y_{\theta}\left(g_{r_{\theta}}-z_{\theta}\right) \prime-1}$. Dado os valores de expressão $x_{r}$ para todos $r \in R_{z}$, o algoritmo percorre toda a árvore de decisão de maneira probabilística, pegando a decisão $y_{\theta} \pm 1$ para cada nó $\theta$. Nessa etapa, a distribuição condicional se associa com a distribuição normal representado por $p\left(x_{g} \mid x_{r}\right)=\sum_{N \in \gamma_{r}} \alpha_{N}\left(x_{r}\right) p\left(x_{g} \mid \mu_{N}, \varphi_{N}\right)$, onde $\alpha_{N}=\prod_{\theta} p\left(y_{\theta} \mid x_{r_{\theta}}, z_{\theta}, \varepsilon_{\theta}\right)$.

Para um módulo inferido a partir de uma matriz de expressão gênica $M_{e x}$ é possível derivar a função de probabilidade posterior para cada gene candidato a regulador de cada nó $\theta$. Cada amostra (condição) pertence a exatamente um conjunto $N$ em $R_{z}$ e, portanto, determina um único caminho da árvore a ser percorrido. Além disso, cada nó $\theta$ tem um conjunto $N_{\theta}$ associado, englobando todos os conjuntos de condições quem pode ser alcançados a partir do nó $\theta$. Com isso, para cada nó é possível inferir $P(r, \gamma) \alpha \max _{\varepsilon}\left(\prod_{n \in N_{\theta}} p\left(y_{\theta}, n \mid x_{r, n}, \gamma, \varepsilon\right)\right)$, onde $\varepsilon$ é o maximizador (melhor escolha). Tipicamente, considera-se como um possível valor de $\gamma$ do módulo o valor de expressão $x_{z, y}$ para $\gamma \in N_{\theta}$.

A probabilidade à posteriori apresentada avalia a eficiência dos possíveis reguladores predizerem a divisão do módulo em dois contextos (dois conjuntos de amostras $N_{\theta}$ ), induzido pela partição condicional $\gamma_{z}$. A seguir é apresentado o pseudocódigo que percorre a árvore e atribue um gene selecionado na primeira etapa de integração de dados como possível regulador de um módulo $z$, selecionando os melhores conjuntos.

Foi definido que $L$ representa uma árvore do conjunto amostral, $C_{\beta}$ representa o conjunto de genes passengers utilizado como referência e $C$ o conjunto de interações proteína-proteína. Caso os módulos formados não apresentem $10 \%$ de interação física entre regulador e genes co-expressos dos módulos ou $20 \%$ de genes passengers presentes nos módulos, eles são quebrados e o processo de formação dos módulos (Seção 5.2.3) e atribuição de reguladores (Seção 5.2.4) recomeça até que a condição seja satisfeita.

\subsubsection{Atribuição de Pontuação ao Regulador}

A pontuação é decorrente da constante associação entre módulos e genes reguladores e depende de todos os genes presentes no módulo. O processo de atribuição de um gene candidato como regulador de um módulo foi reamostrado e os critérios de pontuação seguiram aqueles utilizados por Segal et al. (2003). No caso específico da metodologia implementada, para obter a significância dessa atribuição $S_{\theta}(r)$ foi utilizada uma média de probabilidade de predição, representada por

$$
S_{\theta}(r)=\frac{f_{\theta}}{A t r i b} \sum_{z} p_{\theta}(r, z)
$$

onde $\frac{\left|f_{\theta}\right|}{A t r i b}$ é a escolha natural que demonstra a existência de uma confiança maior na atribuição de nós a outras condições avaliadas. A soma $\sum z$ percorre o conjunto de valores de partição para os reguladores $(r)$ em nó $(\theta)$. A significância total $S_{\theta}(d)$ da atribuição de um regulador a um módulo é definido pela soma dos valores sobre todos os nós processados de um determinado módulo.

$$
Z(r)=\sum_{\theta \in M_{\theta}} \sum_{\varphi \in \theta} z_{\varphi}(r)
$$

onde $\theta \in M_{\theta}$ representa todos os nós do conjunto e $z_{\varphi}(r)$ representa a precição de um módulo 
associado ao regulador.

\subsubsection{Mecanismos para Seleção de Módulos}

Os módulos formados foram enriquecidos para processos biológicos pelo Gene Ontology (GO, disponível em http://www.geneontology.orgâĂÔ), e a significância do enriquecimento foi utilizada como um dos critérios para a escolha dos módulos. Porém, esse tipo de abordagem envolve uma série de problemas associados às anotações biológicas, auxiliando na escolha de módulos pouco representativos. Alguns desses problemas envolvem: (1) a redundância dos termos biológicos, repetidos em fontes variadas de anotação (e.g. ciclo celular: GO:0007049, ciclo celular: KEGG:hsa04110) ou que são segregados em termos muito semelhantes, com o mesmo significado biológico (e.g. ciclo celular: GO:0007049 e processo do ciclo celular: GO:0022402); (2) polarização devido ao uso frequente de certos termos inespecíficos (e.g. GO:0050789 representa regulação do processo biológico, que inclui mais de $44 \%$ de todos os genes humanos anotados); (3) anotação funcional inadequada de vários genes bem descritos (e.g. o gene $N R A S$ não é anotado para GO:0043410, que representa regulação positiva da cascata $M A P K$, mas o papel deste gene na sinalização $M A P K$ é bem conhecida, uma vez que é parálogo ao gene $H R A S$, com função essencial na via). Além disso, genes reguladores podem não apresentar interações físicas com os genes dos módulos, o que contrasta com o objetivo de que eles sejam responsáveis por algum tipo de mudança na expressão dos genes de um módulo. Após análise pelo GO (disponível em www.geneontology.org), foram considerados significativos os módulos enriquecidos para vias com $\mathrm{p}<0,05$.

Com relação às PPI, foram utilizados sete bancos de dados: DIP (disponível em http://dip. doe-mbi.ucla.edu), HiMAP (disponível em https://lib.stanford.edu/himap), IntAct (disponível em www.ebi.ac.uk/intact), MINT (disponível em http://mint.bio.uniroma2.it/mint/Welcome. do), MIPS / MPPI (disponível em http://mips.helmholtz-muenchen.de/proj/ppi), pSTIING (disponível em http://pstiing.licr.org/) e STRING (disponível em http://string-db.org). Todos esses bancos armazenam interações proteína-proteína e diversas anotações a respeito da técnica utilizada (e.g. sistema de duplo híbrido, co-imunoprecipitação, purificação por afinidade em tandem e espectrometria de massa). Foram considerados significativos os módulos que apresentavam alta pontuação de acordo com o programa de regulação e pelo menos $20 \%$ de passengers presentes. Mesmo que o processo de enriquecimento não seja eficiente, como explicado anteriormente, espera-se que a inclusão de novos critérios de seleção auxilie na escolha de módulos com maior representatividade na doença. Em um caso hipotético, se um módulo enriquecido para ciclo celular é formado por vinte genes, o critério de $10 \%$ de interação determina que ao menos dois genes estejam interagindo diretamente com o regulador, propondo uma ação direta entre o candidato a driver e genes que participam do mesmo processo. Caso um regulador seja atribuído a mais de um módulo, esse critério pode auxiliar na escolha do módulo com maior relevância para a doença.

\subsubsection{Parâmetros Pré-definidos para Formação do Conjunto Driver-Módulo}

Alguns parâmetros adicionais foram definidos:

- Numero mínimo de 12 amostras (de 31 possíveis de CaPe) em uma folha da árvore de 
regressão para ser considerada a divisão do cluster (módulo) em expressão aumentada e diminuída. Caso contrário, não ocorre divisão.

- Utilização da centróide entre as expressões aumentada e diminuída para garantir que a divisão do módulo não esteja muito longe do centro da variância da expressão.

- A divisão só continua se durante o teste com 1.000 permutações para identificação de possíveis novos reguladores (drivers) a significância for determinada por $p<0,05$.

- Foram consideradas três amostras (10\% das 31 amostras de CaPe) como o número máximo de módulos que um gene pode ser adicionado. Caso o gene ultrapasse o limiar definido, ele não é adicionado ao(s) módulo(s) correspondente(s).

- Cada módulo formado deve apresentar, no mínimo, $10 \%$ de genes com interações proteínaproteína associando reguladores (drivers) e genes presentes nos módulos.

- Cada módulo formado deve apresentar, como limiar, 20\% de genes passengers em cada módulo para que o mesmo seja formado. Caso contrário, recomeça o processo de atribuição de um regulador ao módulo correspondente.

\subsection{Especificação dos Dados e Plataformas}

Cada plataforma utilizada foi caracterizada de acordo com suas possíveis alterações. Os dados de CNA foram classificados de acordo com as possíveis alterações genômicas "NA", "A", "D", "DD" e "G"(i.e., sem alteração, amplificação, deleção hemizigótica, deleção homozigótica e ganho de cópias do DNA, respectivamente). Essas informações foram obtidas a partir da seleção das regiões significantes e frequentemente alteradas ( $p<0,05$ e frequência maior que 20\%) e posteriormente comparadas com o banco de variantes genômicas DGV (Database of Genomic Variants, disponível em http://projects.tcag.ca/variation/) classificando as regiões como: "nova", "rara"ou "comum". As regiões comuns estão presentes no DGV com uma frequência maior que $1 \%$ em comparação com outros estudos. Regiões "raras" apresentavam sobreposição de até $50 \%$ da região com estudos já descritos e frequência menor que 1\%. Já as regiões "novas" estão ausentes no banco de dados. Os dados de metilação também foram distribuídos em $\mathrm{m}$ linhas e n colunas, onde cada gene foi classificado como hipermetilado se $\log _{2}<0$ e hipometilado, se $\log _{2}>0$. Foram selecionados apenas genes com alterações na metilação em pelo menos $52 \%$ dos casos (16/31) e $40 \%$ de sondas alteradas para cada gene. Os valores foram arredondados, e.g. no caso do gene ser coberto por três sondas, pelo menos duas deveriam apresentar alterações na metilação. Os miRNAs diferencialmente expressos foram classificados de acordo com sua expressão aumentada ou diminuída no conjunto de amostras. Os alvos desses miRNAs foram localizados nos bancos de predição Targetscan (disponível em www.targetscan.org), PicTar (disponível em pictar.mdc-berlin.de), MicroCosm (disponível em www.ebi.ac.uk/enright-srv/microcosm/) e microRNA.org (disponível em www.microrna.org).

Na comparação entre alterações genômicas e expressão gênica, a hipótese nula $(H 0)$ é que a diferença na expressão obtida da comparação entre amostras tumorais e normais não se correlacionam com o estado de alterações de cópias do DNA. O mesmo se aplica para as outras variáveis quando comparadas com os dados de expressão gênica. Para avaliar o grau de dependência entre 
os genes foi realizada uma correlação, considerando aqueles cuja correlação satisfazia as questões biológicas. (e.g. considerando $X$ a variável de expressão gênica e $Y$ a variação de metilação é esperado que $\left.-1 \geq r_{x y}<0\right)$.

\subsubsection{Array-Comparative Genomic Hybridization - aCGH}

Para a identificação de alterações no número de cópias de DNA foi utilizada a plataforma Human Genome CGH microarray 4x44K (Agilent), composta por sequências com 60pb e espaçamento médio de aproximadamente $74 \mathrm{~Kb}$. Essa plataforma possui 45.015 sondas que mapeiam genes bem caracterizados, particularmente envolvidos em câncer, além de sequências codificadoras e não codificadoras (disponível em http://www.chem.agilent.com).

Os dados foram filtrados e normalizados pelo programa Feature Extraction 10.1.1.1 (Agilent), de acordo com as características e qualidade das amostras. Em seguida, foi aplicado um método de segmentação pelo algoritmo GLAD (Hupe et al. , 2004) para a identificação de segmentos envolvidos em ganhos e perdas no conjunto de amostras $(p<0,05)$. Para a identificação das regiões alteradas a partir dos segmentos, foi utilizado o algoritmo GISTIC (Beroukhim et al. , 2007). Nesta análise, para cada alteração foi atribuído um G-score que considera a sua amplitude e frequência de ocorrência no conjunto total. Para cada região alterada foi identificado o q-valor e selecionadas aquelas que apresentavam um limiar abaixo de 0,1 .

As alterações do número de cópias genômicas foram classificadas como: ganhos (uma cópia adicional, definida pelo valor de $\log 2>0,4$ ), perdas hemizigóticas (uma cópia ausente, definida pelo valor de $\log 2<-0,4$ ), amplificação (duas ou mais cópias adicionais, definido pelo valor de $\log 2>0,8$ ) e perda homozigótica (duas cópias ausentes, definida pelo valor de $\log 2<-1,2$ ). As regiões identificadas foram comparadas com dados disponíveis no DGV e classificadas como: "comuns", "raras" e "novas". Dados disponíveis na Tabela 3.

Com relação às análises entre amostras tumorais e normais de CaPe foram mantidas apenas regiões alteradas com frequência maior que 20\%, resultando em 411 genes alterados em 49 regiões significantes com $p<0,05$, sendo 141 ganhos (34,4\%), 10 perdas homozigóticas $(2,44 \%)$, 9 ganhos em alto nível (2,2\%) e 251 perdas hemizigóticas (60,8\%). Os ganhos genômicos (ganhos de uma cópia e amplificação) envolveram principalmente os cromossomos 16 e 19 (24 e 33 eventos, respectivamente), enquanto as perdas cromossômicas (deleções homozigóticas e hemizigóticas) ocorreram principalmente nos cromossomos 1, 11, 22 e Y, sendo 28, 32, 30 e 36 eventos respectivamente.

Tabela 3: Representação das alterações do número de cópias do DNA significativamente identificadas pelo algoritmo GISTIC $(p<0,05, q<0,1)$

\begin{tabular}{ccccccc}
\hline Cromossomo & Citobanda & Comprimento & Evento & Genes & P-Valor & DGV \\
\hline 1 & $\mathrm{p} 36.13$ & 226749 & Ganho & 4 & 0,003 & rara \\
1 & $\mathrm{p} 36.13-\mathrm{p} 36.12$ & 387821 & Perda & 28 & 0,032 & rara \\
2 & $\mathrm{p} 23.2-\mathrm{p} 23.1$ & 816536 & Perda & 1 & 0,02 & comum \\
2 & $\mathrm{q} 37.1$ & 81415 & Perda & 6 & 0,006 & rara \\
2 & $\mathrm{q} 37.3$ & 442266 & Ganho & 7 & 0,047 & comum \\
3 & $\mathrm{q} 25-\mathrm{q} 26.31$ & 285715 & Ganho & 9 & 0 & comum \\
3 & $\mathrm{p} 23-\mathrm{p} 22$ & 285715 & Perda & 7 & 0 & comum \\
4 & $\mathrm{p} 16.2$ & 513418 & Perda & 5 & 0 & rara \\
4 & $\mathrm{q} 35.2$ & 941518 & Perda & 4 & 0,004 & rara \\
5 & $\mathrm{q} 21$ & 1667961 & Perda & 6 & 0 & rara
\end{tabular}




\begin{tabular}{|c|c|c|c|c|c|c|}
\hline 7 & $7 q 31$ & 1042311 & Perda & 8 & 0 & comum \\
\hline 7 & $7 \mathrm{p} 21$ & 311412 & Perda & 2 & 0 & comum \\
\hline 8 & $\mathrm{q} 21.3$ & 951944 & Perda & 2 & 0,011 & rara \\
\hline 8 & $\mathrm{p} 22$ & 214780 & Perda & 4 & 0 & comum \\
\hline 9 & $\mathrm{p} 23$ & 1028188 & Perda & 1 & 0,045 & comum \\
\hline 9 & $\mathrm{p} 21.3$ & 239337 & Ganho & 4 & 0 & rara \\
\hline 9 & q21.33 & 135597 & Perda & 4 & 0,045 & rara \\
\hline 10 & $\mathrm{p} 12.1$ & 113641 & Perda & 4 & 0,024 & rara \\
\hline 10 & $\mathrm{p} 12.2$ & 512003 & Ganho & 11 & 0,007 & comum \\
\hline 11 & $\mathrm{p} 15.4$ & 425026 & Perda & 31 & 0,005 & comum \\
\hline 11 & q13.1 & 36126 & Ganho & 8 & 0,009 & rara \\
\hline 11 & q23-q24 & 461717 & Perda & 1 & 0,049 & rara \\
\hline 12 & $\mathrm{p} 13.31$ & 137399 & Ganho & 5 & 0,005 & comum \\
\hline 12 & $\mathrm{q} 24.22$ & 233394 & Ganho & 2 & 0,008 & comum \\
\hline 12 & q24.31 & 111257 & Ganho & 5 & 0,008 & rara \\
\hline 13 & q13.2 & 393933 & Perda & 2 & 0,021 & rara \\
\hline 13 & $\mathrm{q} 14.2$ & 226791 & Ganho & 3 & 0,001 & rara \\
\hline 14 & $\mathrm{q} 24$ & 594580 & Perda & 3 & 0,018 & rara \\
\hline 15 & $q 22$ & 89108 & Perda & 3 & 0,005 & comum \\
\hline 16 & p13.3 & 239154 & Ganho & 24 & 0,01 & comum \\
\hline 16 & $\mathrm{p} 13.3$ & 111965 & Perda & 12 & 0,021 & comum \\
\hline 16 & $\mathrm{p} 11.2$ & 235397 & Perda & 10 & 0 & comum \\
\hline 17 & p13.3 & 128546 & Perda & 5 & 0,032 & rara \\
\hline 17 & q11.1-q11.2 & 277896 & Perda & 5 & 0,025 & comum \\
\hline 17 & q24-q25 & 207559 & Ganho & 9 & 0,032 & rara \\
\hline 18 & p11.31 - p11.21 & 9830873 & Perda & 4 & 0 & comum \\
\hline 19 & $\mathrm{p} 13.2$ & 142846 & Ganho & 12 & 0,023 & comum \\
\hline 19 & q13.33 & 78075 & Perda & 9 & 0,018 & rara \\
\hline 19 & q13.33 & 145582 & Ganho & 11 & 0,032 & rara \\
\hline 19 & q13.42 & 62901 & Perda & 7 & 0,018 & comum \\
\hline 19 & q13.42 & 112982 & Ganho & 10 & 0,032 & rara \\
\hline 20 & q13.12 & 299553 & Perda & 4 & 0,018 & comum \\
\hline 21 & q11 & 305282 & Ganho & 9 & 0 & rara \\
\hline 22 & q13.33 & 325248 & Perda & 30 & 0,004 & comum \\
\hline $\mathrm{X}$ & $\mathrm{p} 11.22$ & 989280 & Ganho & 17 & 0,006 & rara \\
\hline $\mathrm{X}$ & q28 & 545455 & Perda & 8 & 0,031 & comum \\
\hline $\mathrm{X}$ & $\mathrm{q} 28$ & 102491 & Perda & 9 & 0,031 & rara \\
\hline $\mathrm{Y}$ & q11.21 & 663688 & Perda & 5 & 0,013 & comum \\
\hline $\mathrm{Y}$ & q11.22 - q11.23 & 3583709 & Perda & 31 & 0,013 & comum \\
\hline
\end{tabular}

No estudo comparando amostras positivas e negativas para infecção pelo HPV foram consideradas apenas alterações significativas presentes em mais de $20 \%$ dos casos e com $p<0,05$. Os critérios para a classificação genômica das alterações e das CNVs foram os mesmos daqueles apresentados anteriormente. Foram identificadas 19 regiões alteradas, com 150 genes, sendo 77 ganhos de cópias e 73 deleções hemizigóticas. Os resultados dessa análise estão apresentados na Tabela 4.

\subsubsection{Análise de Expressão Gênica em Larga-Escala (Microarray)}

O perfil de expressão gênica foi avaliado pela plataforma Whole Human Genome 4x44K (Agilent), composta por 43.376 sequências biológicas e 32 sondas para controles positivos Spike in (disponível em http://www.genomics.agilent.com). Os procedimentos de marcação das amostras, 
Tabela 4: Alterações referentes à comparação entre amostras positivas e negativas para infecção pelo HPV em 31 amostras de carcinoma de pênis. A coluna de frequência representa os valores exclusivos para HPV + em comparação com HPV

\begin{tabular}{|c|c|c|c|c|c|c|}
\hline Cromossomo & Citobanda & Evento & $\begin{array}{c}\text { Genes } \\
(\% \text { HPV }+)\end{array}$ & Frequência & P-Valor & DGV \\
\hline 1 & $\mathrm{q} 31.3$ & Ganho & 3 & 30,76 & 0,022 & comum \\
\hline 2 & q35 & Perda & 2 & 30,76 & 0,022 & rara \\
\hline 2 & q35 & Perda & 15 & 30,76 & 0,022 & rara \\
\hline 2 & q35 & Perda & 11 & 30,76 & 0,022 & rara \\
\hline 2 & q35 & Perda & 8 & 30,76 & 0,022 & comum \\
\hline 2 & $\mathrm{q} 36.3$ & Perda & 3 & 30,76 & 0,022 & rara \\
\hline 2 & $\mathrm{q} 36.3$ & Perda & 1 & 30,76 & 0,022 & rara \\
\hline 2 & $\mathrm{q} 36.3$ & Perda & 2 & 38,46 & 0,007 & rara \\
\hline 2 & $\mathrm{q} 36.3$ & Perda & 6 & 30,76 & 0 & rara \\
\hline 2 & $\mathrm{q} 37.1$ & Perda & 7 & 30,76 & 0,022 & rara \\
\hline 2 & $\mathrm{q} 37.1$ & Perda & 8 & 38,46 & 0,007 & rara \\
\hline 2 & q37.1 & Perda & 7 & 30,76 & 0,022 & rara \\
\hline 3 & q22-q23 & Perda & 3 & 30,76 & 0 & rara \\
\hline 3 & $\mathrm{q} 27.3$ & Ganho & 1 & 30,76 & 0,022 & rara \\
\hline 19 & q13.31 - q13.32 & Ganho & 2 & 30,76 & 0,022 & rara \\
\hline 19 & $\mathrm{q} 13.32$ & Ganho & 5 & 38,46 & 0,007 & rara \\
\hline 19 & q13.32 & Ganho & 21 & 30,76 & 0,022 & rara \\
\hline 19 & q13.32 & Ganho & 42 & 30,76 & 0,022 & rara \\
\hline 20 & p12 & Ganho & 3 & 30,76 & 0,022 & rara \\
\hline
\end{tabular}

hibridação e deteç̧ão seguiram o protocolo Two-color microarray-based gene expression analysis (Agilent Technologies) que utiliza o Quick Amp Labeling Kit (Agilent). As lâminas foram analisadas em scanner Agilent utilizando o software Scan Control 8.1 (Agilent) e os dados extraídos com o programa Feature Extraction 10.1.1.1 (Agilent). Todas as 31 amostras preencheram os critérios de qualidade do fabricante, o que inclui análises de background, uniformidade da hibridação, intensidade dos sinais fluorescentes (verde e vermelho) e variação das replicatas.

Ao analisar os dados de expressão gênica, alguns oligonucleotídeos de 60pb não foram interpretados de acordo com a lista de genes disponibilizada pelo fabricante, pois se alinhavam com transcritos de outros genes. Foi necessário realizar uma anotação sistemática de todos os cromossomos, implementando o algoritmo de Gertz et al. (2009). A Figura 8 apresenta as etapas dessa análise que resultou na filtragem de 6.253 sondas.

Posteriormente as sondas foram filtradas de acordo com a qualidade do sinal obtido pelo scanner e consideradas apenas aquelas que apresentavam desvio padrão maior que 0,25 , resultando 


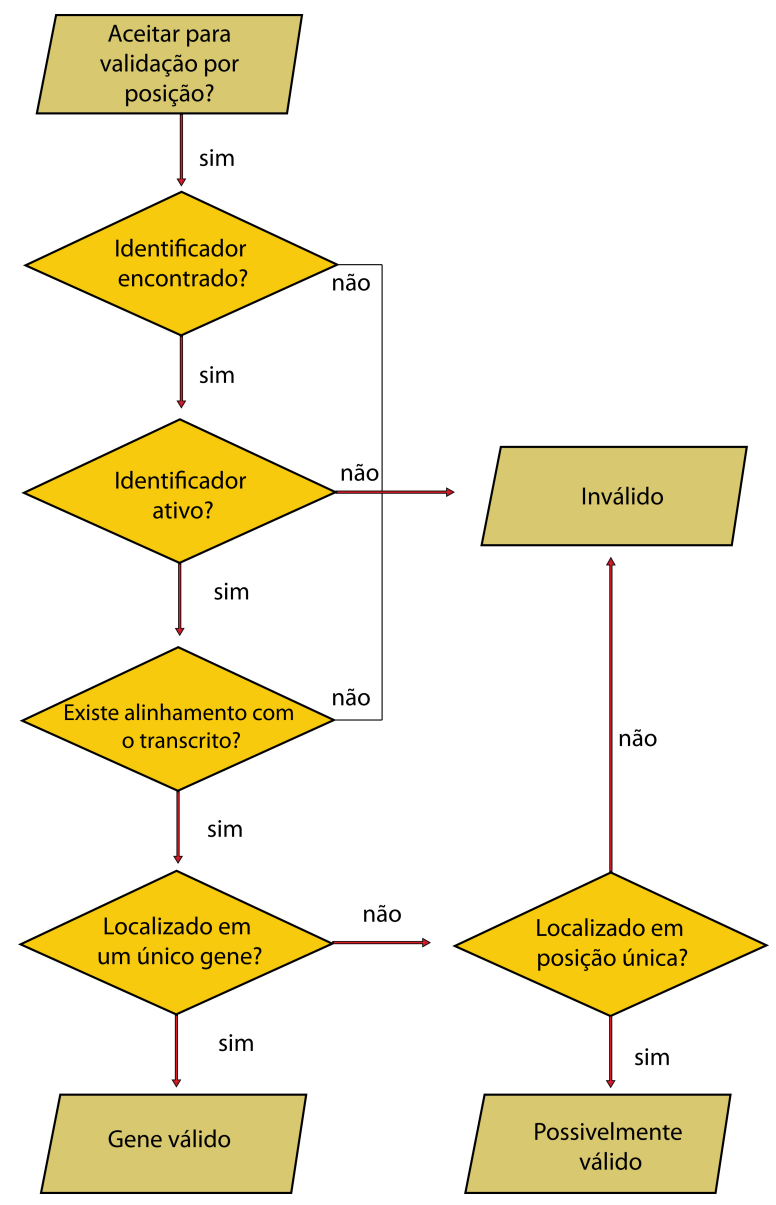

Figura 8: Fluxograma adaptado de Gertz et al. (2009) mostrando o processo de validação de sondas por posição, categorizando-as como: válidas, possivelmente válidas e inválidas. As sondas inválidas foram excluídas da análise.

em 9.253 sondas cobrindo 8.445 genes. Para as sondas que não apresentavam reprodutibilidade, de acordo com os critérios do filtro utilizado, foi atribuído "NA". Em ambos os estudos (tumor/normal e HPV+/HPV-) os dados foram analisados pelo pacote samr (Tibshirani et al. , 2011) para identificação das sondas significantes, resultando em 5.251 genes na comparação entre amostras tumorais e normais e 475 genes obtidos da comparação entre os carcinomas de pênis positivos e negativos para infecção pelo HPV. A Figura 9 apresenta uma relação entre as alterações encontradas e os cromossomos, em ambos os estudos.

\subsubsection{Análise de Metilação}

O perfil de metilação foi avaliado pela plataforma Human DNA Methylation Array (G4495A, AMADID 023795, formato 244K) (Agilent), que apresenta 237.227 sondas espaçadas por $97 \mathrm{pb}$ cobrindo $21 \mathrm{MB}$ do genoma. A abrangência é de 27.627 ilhas CpGs conhecidas com aproximadamente 8 sondas por ilha além de 5.081 regiões não metiladas e ilhas CpGs expandidas. Os dados foram normalizados para a correção de ligações não específicas das sondas. Durante a análise, foi considerada uma distância de 1.000 pb entre sondas e $p<1 x 10^{-3}$.

Foi utilizado um método de análise removendo os NAs das tabelas para a filtragem de sondas com baixa qualidade após a hibridação. Posteriormente, foram selecionadas apenas sondas com significância de $p<1 \times 10^{-3}$, fold-change $\geq 1,5$ (comparação entre tumor e normal) e frequência 


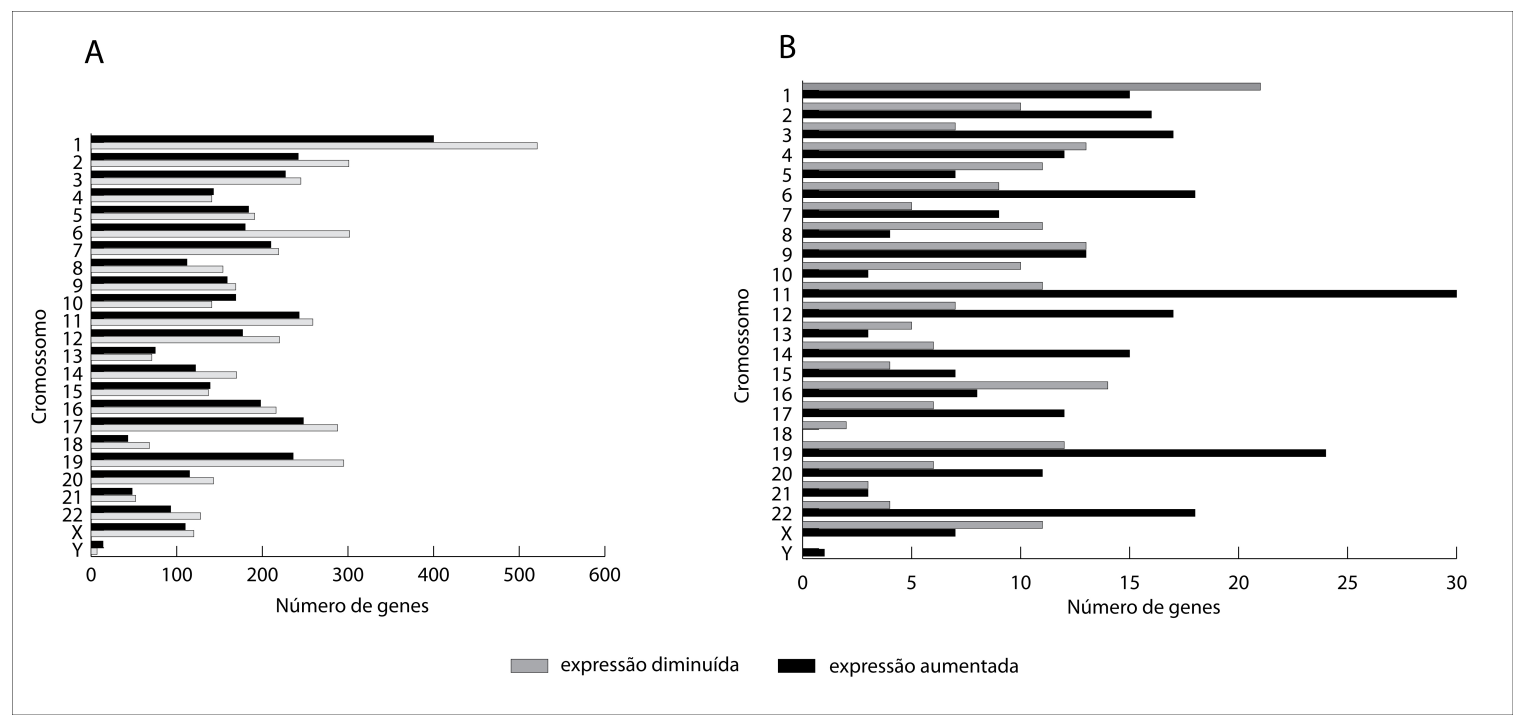

Figura 9: (A) Representação do número de genes diferencialmente expressos obtidos da comparação entre amostras tumorais e normais de pênis. A barra na cor preta significa expressão aumentada (3.151/5.251 - frequência de 60\%) e a barra cinza, expressão diminuída (2.100/5.251 - frequência de 40\%). Em (B), gráfico representando o número de genes diferencialmente expressos obtidos da comparação entre amostras positivas e negativas para a infecção pelo vírus. A barra na cor preta representa expressão aumentada (231/475- frequência de $48.6 \%$ ) e a barra cinza, expressão diminuída (244/475 - frequência de $51.4 \%)$.

de hipermetilação ou hipometilação maior que $20 \%$, i.e., uma sonda precisa estar alterada em pelo menos doze amostras. Em alguns casos, mais de uma sonda foi responsável pela cobertura das ilhas CpGs de um gene. Um gene foi considerado hipermetilado ou hipometilado se pelo menos $50 \%$ das sondas que cobrem esse gene passaram pelos critérios anteriores. No estudo envolvendo amostras tumorais e normais de CaPe, foram selecionados 1.400 genes com alterações na metilação do DNA, sendo 551 genes hipermetilados e 849 genes hipometilados. Com relação à comparação entre amostras positivas e negativas para infecção pelo HPV em CaPe, 448 genes foram identificados, sendo 298 hipermetilados e 150 genes hipometilados. As Figuras 10 e 11 apresentam a quantidade de alterações encontradas com relação ao cromossomo em ambos os estudos.

\subsubsection{Análise de miRNA}

Foram selecionadas 37 amostras de tecidos de pênis: $25 \mathrm{CaPe}(\mathrm{T}), 7$ tecidos normais adjacentes (S) e 5 glandes obtidas em autópsias de indivíduos post morten (G). A quantificação da expressão de miRNAs foi realizada pelo sistema TaqMan Human MicroRNA Assay Set v2.0 (Applied Biosystems) no aparelho 7900 HT Fast Real Time PCR (Applied Biosystems).

Para a síntese de cDNA foi utilizado um conjunto de iniciadores pré-definidos desenhados de forma que permaneçam em uma estrutura de loop (Megaplex RT Primers, Applied Biosystems). Este sistema permite a ligação dos iniciadores a centenas de miRNAs alvos em um único experimento e reduz o número de reações de transcrição reversa (RT) e a quantidade de RNA necessária para as reações. O pool de iniciadores Megaplex RT primers (Human Pool A) foi utilizado para os ensaios com as plataformas de array. Este kit contém iniciadores para 377 miRNAs específicos e para três miRNAs controles endógenos e um controle negativo.

Para a PCR foram adicionados $450 \mu \mathrm{L}$ de TaqMan Universal PCR Master Mix, No AmpErase 


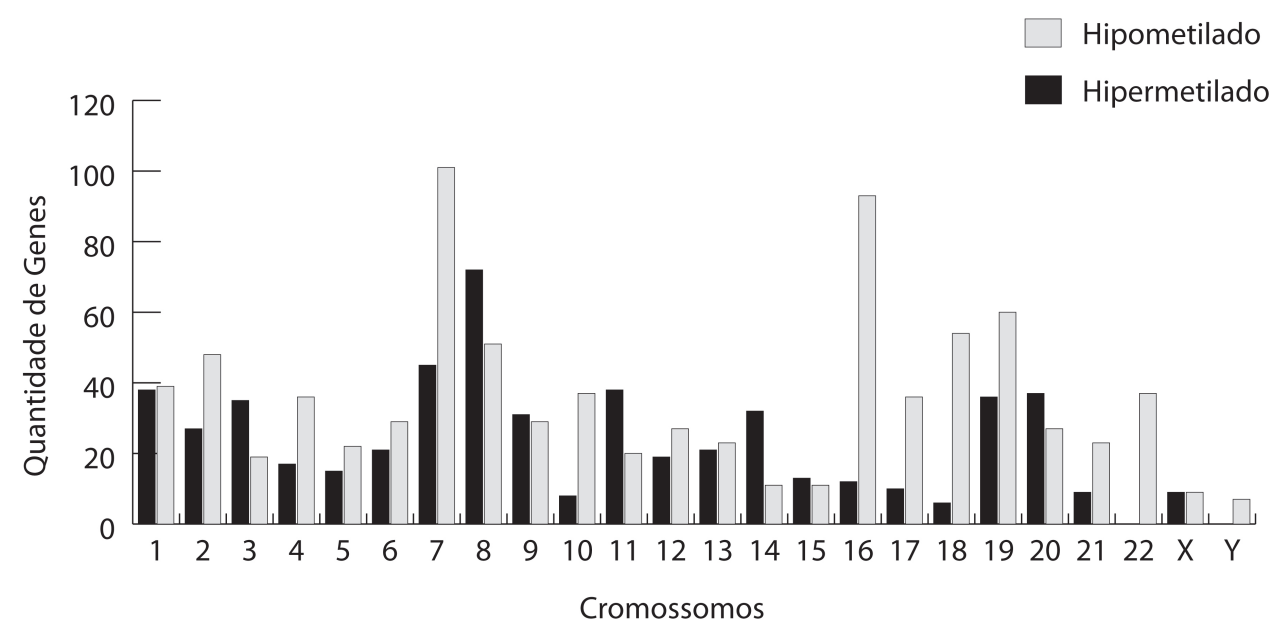

Figura 10: Representação dos genes com alterações nos níveis de metilação em CaPe (comparação entre amostras tumorais e normais), separados por cromossomo. As barras na cor cinza representam os genes hipometilados e as barras na cor preta, genes hipermetilados. Nota-se uma frequência maior de hipometilação nos cromossomos 7, 16 e 19. Com relação à hipermetilação, os cromossomos 7, 8, 18 e 19 aparecem com maior frequência de alterações.

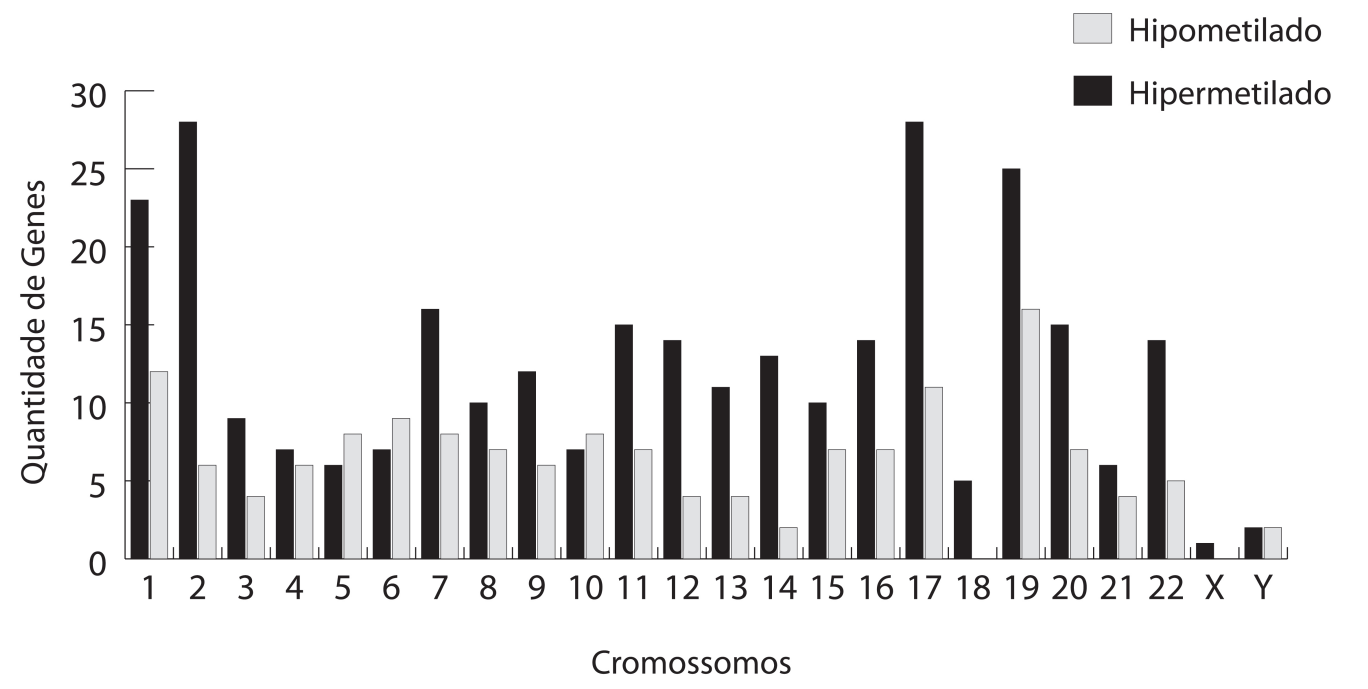

Figura 11: Genes metilados na comparação entre amostras positivas e negativas para o HPV em CaPe. As barras na cor cinza e preta representam genes hipometilados e hipermetilados, respectivamente. É possível identificar uma frequência maior de hipermetilação nos cromossomos 1, 2, 17 e 19 . Os genes hipometilados se concentram em maior quantidade nos cromossomos 1, 17 e 19.

$U N G, 2 \mathrm{X}$ (Applied Biosystems), $6 \mu \mathrm{L}$ do produto amplificado e $444 \mu \mathrm{L}$ de água, deste mix, um volume de $100 \mu \mathrm{L}$ foi transferido para cada uma das 8 portas de entrada da plataforma TaqMan MicroRNA Array que são conectadas por canais de microfluidos até os 48 micro-wells que contém os primer/probe TaqMan liofilizados. A plataforma foi centrifugada duas vezes por 1 minuto a $1200 \mathrm{rpm}$ para distribuição uniforme do líquido na porta de entrada da plataforma a cada um dos micro-wells. A plataforma foi selada e levada ao Biosystems Prism 7900HT Fast Real-Time PCR sequence detection System (Applied Biosystems) para quantificar os níveis de expressão de cada miRNA.

Os miRNAs utilizados no estudo foram selecionados a partir da comparação entre amostras tumorais e normais e entre amostras HPV + e HPV-, com seleção dos miRNA diferencialmente expressos, com fold-change $>1,5$ e $p<0,05$. Para a identificação dos alvos dos miRNAs foram 
utilizadas informações de predição obtidas no banco de dados mirDIP (disponível em http:// ophid.utoronto.ca/mirDIP), que integra seis bancos de predição e permite a utilização de recall e precision como um dos critérios de seleção dos genes alvos. A Tabela 5 apresenta os miRNAs utilizados nos estudos.

Tabela 5: Representação dos miRNAs diferencialmente expressos obtidos nas comparações entre amostras tumorais e normais de CaPe e positivas e negativas para infecção pelo HPV.

\begin{tabular}{cccc}
\hline \multicolumn{2}{c}{ Tumor vs } & Normal & \multicolumn{2}{c}{ HPV+vs HPV- } \\
miRNA & Fold-change & miRNA & Fold-change \\
\hline hsa-miR-135b & 238.73 & $h s a-m i R-517 b$ & -586.00 \\
hsa-miR-429 & 225.66 & $h s a-m i R-589$ & -51.51 \\
hsa-miR-31 & 147.05 & $h s a-m i R-520 b$ & -18.64 \\
hsa-miR-182 & 48.95 & $h s a-m i R-218$ & -13.31 \\
$h s a-m i R-424$ & 11.09 & $h s a-m i R-328$ & -5.60 \\
$h s a-m i R-130 b$ & 10.10 & $h s a-m i R-618$ & -4.67 \\
hsa-miR-20a & 5.76 & $h s a-m i R-512-5 p$ & -2.72 \\
$h s a-m i R-139-5 p$ & -2.28 & $h s a-m i R-99 a$ & -2.04 \\
$h s a-m i R-484$ & -2.31 & $h s a-m i R-154$ & -1.99 \\
$h s a-m i R-134$ & -2.32 & $h s a-m i R-296-5 p$ & -1.61 \\
$h s a-m i R-320$ & -2.51 & $h s a-m i R-627$ & -1.51 \\
$h s a-m i R-191$ & -2.54 & & \\
$h s a-m i R-574-3 p$ & -2.63 & & \\
$h s a-l e t-7 c$ & -2.74 & & \\
$h s a-m i R-145$ & -2.77 & & \\
$h s a-m i R-28-3 p$ & -2.78 & & \\
\hline
\end{tabular}

\subsection{Identificação de Possíveis Reguladores}

A identificação de possíveis reguladores dos genes selecionados nas duas abordagens biológicas propostas (análises Tumor vs Nornal e HPV + vs HPV-) utilizou uma compilação de diferentes bancos de dados disponíveis na literatura, como bancos de vias biológicas: KEGG (disponível em www.genome.jp/kegg/), Pathway Interaction (disponível em http://pid.nci.nih.govâ̆̆Ô), MetaCyc (disponível em www.metacyc.orgâĂŐ), Pathguide (disponível em http://www.pathguide. org) e REACTOME (disponível em http://www.reactome.org) e de alvos de miRNAs: Targetscan (disponível em www.targetscan.org), PicTar (disponível em pictar.mdc-berlin.de), MicroCosm (disponível em www.ebi.ac.uk/enright-srv/microcosm/) e microRNA.org (disponível em www.microrna.org).

Posteriormente, as informações obtidas foram comparadas com a literatura para identificação dos termos mais representativos, utilizando o algoritmo LitVAn (disponível em http://litvan.bio. columbia.edu/index.php\#). Esse algoritmo de análise vetorial da literatura utiliza um banco de dados com mais de 70.000 artigos científicos publicados para a identificação de termos mais representativos baseados no cálculo $\mathrm{TF}^{*} \mathrm{IDF}$, onde TF é a frequência do termo (do inglês Term Frequency) e IDF é a frequência inversa de documentos (do inglês Inverse Document Frequency) definindo a importância do termo dentro de um conjunto de dados. O cálculo TF*IDF atribui um peso, que seria o número de ocorrências do termo no artigo, modificada por uma escala de importância do termo. Os genes e vias com maior representatividade foram organizados em módulos e foi feito um enriquecimento entre os genes obtidos nos estudos de CaPe e os módulos 
encontrados. Em seguida os genes foram comparados com o banco de dados HTRI (do inglês, Human Transcriptional Regulation Interactions database, disponível em http://www.lbbc.ibb. unesp.br/htri/search.jsp) para a identificação de possíveis reguladores transcricionais. Esse banco de dados foi desenvolvido por Bovolenta et al. (2012).

Como exemplo, genes presentes na via do ciclo celular foram comparados com a literatura e foi identificado que dentre 128 genes do módulo que representa a via, o gene $R B 1$ apresentava alta pontuação. Os genes desse módulo foram comparados com a lista de genes obtidos nos estudos de CaPe para um enriquecimento e foram identificados os genes DIO2, DNMT1, KIAA0101, MET, $M S X 1$ e PPARG, enriquecidos com p $<0,05$. Como o gene $R B 1$ apresentava alta pontuação, ele foi comparado com o banco HTRI. Devido a presença desse gene no banco de dados foi sugerido que o $R B 1$ é um possível regulador dos genes encontrados no estudo do carcinoma de pênis. A Figura 12 apresenta as etapas dessa análise.

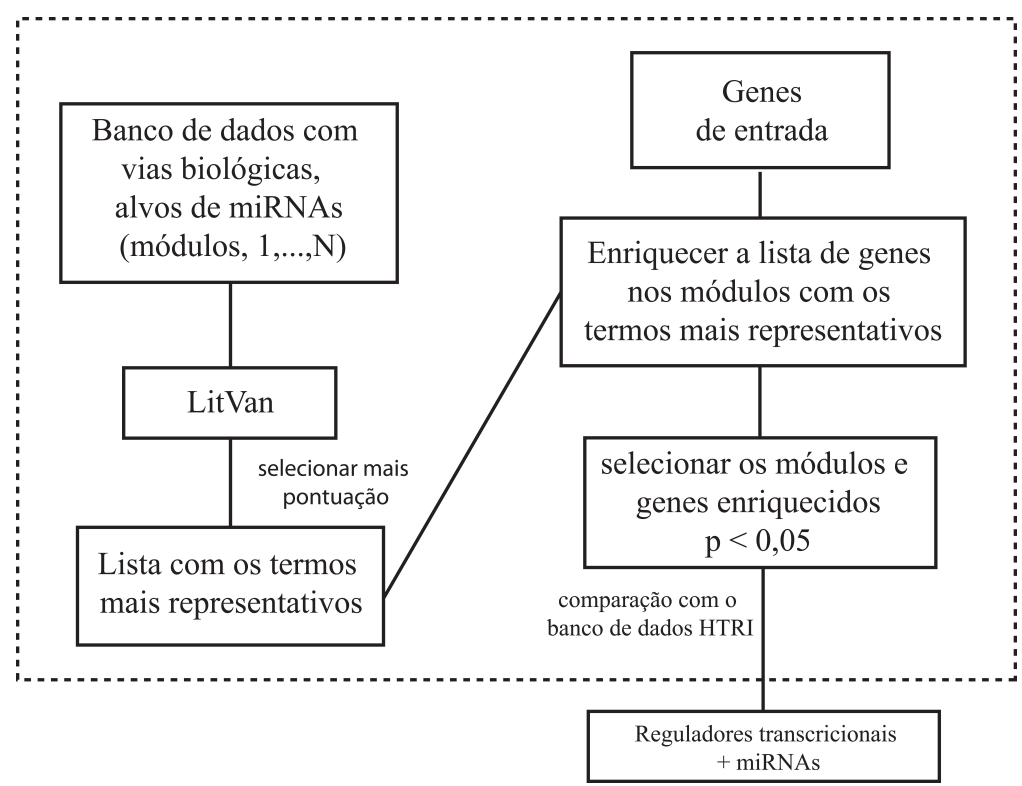

Figura 12: Método para identificação de possíveis reguladores, considerando os bancos de dados de vias biológicas: KEGG, Pathway Interaction, MetaCyc, Pathguide, e REACTOME e predição de alvos de miRNAs (Targetscan, PicTar, MicroCosm e microRNA). Os genes de entrada associados com a lista de termos mais representativos foram comparados com o banco de dados HTRI (Human Transcriptional Regulation Interaction Database) para seleção de possíveis reguladores. 


\subsection{Meta Análise}

Para avaliar o perfil de expressão gênica dos estudos aqui propostos foram feitas duas metaanálises considerando amostras obtidas nos bancos de dados TCGA ( The Cancer Genome Atlas, disponível em http://tcga-data.nci.nih.gov/) e NCBI - GEO (disponível em http://www.ncbi. nlm.nih.gov/geo). Para a seleção das amostras no TCGA foi utilizado o nível 3 (alterações significantes) e consideradas tanto as amostras tumorais e normais quanto às amostras positivas e negativas para infecção pelo vírus. Essa seleção resultou em 1.066 amostras tumor/normal e 210 amostras HPV+/HPV-. A comparação entre os grupos foi feita utilizando o teste t, considerando $p<0,05,1.000$ permutações e $\mathrm{FDR}<0,05$. Com relação às amostras, foram utilizados os seguintes carcinomas cervicais, de cabeça e pescoço e pulmão. O tumor de esôfago também estava disponível no TCGA, porém não apresentava dados disponíveis para alterações de transcritos codificadores. Com relação às buscas no NCBI foram priorizados os estudos que avaliaram a infecção pelo HPV tanto em carcinoma de cabeça e pescoço quanto cervical.

\subsection{Metodologias de Validação in situ e in silico.}

\subsubsection{Validação in situ}

A utilização da metodologia para integração de dados levou à seleção de genes que foram posteriormente submetidos à validação por metodologias independentes. Para a validação dos genes obtidos da comparação entre amostras tumorais e normais de CaPe foram utilizadas as técnicas de RT-qPCR (34 amostras de CaPe e quatro glandes normais), qPCR (34 CECs de pênis e 10 amostras utilizadas como referência normal de sangue obtidas de indivíduos sem histórico de câncer pessoal ou na família) e pirosequenciamento (88 amostras, sendo $47 \mathrm{CaPe}$, 28 tecidos normais adjacentes, 11 glandes). Para a validação dos genes obtidos da comparação entre amostras HPV+ e HPV- foram utilizadas as metodologias de RT-qPCR (34 CaPe, sendo 11 positivos e 23 negativos para infecção por HPV) e pirosequenciamento ( 55 tumores, sendo 18 casos de HPV positivos e 37 casos HPV negativos). Todas as análises estatísticas foram realizadas utilizando o programa $\mathrm{R}$ (disponível em http://www.r-project.org/), com a utilização de pacotes do Bioconductor (disponível em http://www.bioconductor.org/), SPSS 17.0 (SPSS, Chicago, IL) e GraphPad Prism 5.0 (GraphPad Software Inc., La Jolla, CA).

\subsubsection{Validação in silico: Redes em Módulos e Metodologia de Integração de Dados}

O processo de validação in silico foi separado em duas etapas: (1) validação da metodologia de integração de dados e (2) validação do algoritmo adaptado de redes em módulos. Para avaliar a capacidade de identificação de alterações que possam ser consideradas drivers foram utilizadas amostras de glioblastoma multiforme (GBM), um tipo de tumor cerebral maligno de rápido crescimento e mais comum em adultos. O National Cancer Institute (NCI) estimou que no ano de 2012, cerca de 22.910 adultos (12.630 homens / 10.280 mulheres) foram diagnosticados com esse tumor e aproximadamente 13.700 foram a óbito. O GBM é responsável por aproximadamente $15 \%$ de todos os tumores cerebrais e ocorre em adultos entre as idades de 45 a 70 anos. Pacientes com GBM geralmente sobrevivem menos de 15 meses após o diagnóstico.

Com relação à casuística, foram utilizadas amostras obtidas no The Cancer Genome Atlas (disponível em http://cancergenome.nih.gov/dataportal) para três níveis de alteração: CNA (me- 
tilação e expressão de mRNA e miRNA. Como referência, foi utilizada uma lista com 56 genes relacionados ao GBM obtidos do estudo de Frattini et al. (2013).

A metodologia de integração de dados foi avaliada em um estudo independente com 255 amostras de GBM considerando CNA, metilação e expressão gênica. Para os dados de CNA foi utilizada a plataforma Agilent Human Genome CGH microarray 244A e selecionados 1.109 genes com alteração no número de cópias obtidos pelo algoritmo GISTIC $(q<0,2)$. Os dados de expressão gênica foram obtidos a partir da plataforma Agilent Gene Expression 244K e após o processamento das informações foram identificados 2.280 genes diferencialmente expressos entre amostras normais e tumorais. Com relação aos dados de metilação, foram identificados 1.425 genes alterados obtidos a partir da plataforma Illumina Infinium 27K.

Para validar as alterações realizadas na metodologia de redes em módulos foram utilizados apenas dados de microarray de expressão (2.880 genes diferencialmente expressos). Como as metodologias de Segal et al. (2003) e Michoel et al. (2007) não propõem a integração de dados, a validação teve como objetivo avaliar a eficiência na 1) identificação de interações verdadeiropositivas entre genes co-expressos nos módulos e os reguladores, 2) detecção de genes considerados passengers nos módulos formados e 3) identificação de genes presentes na lista de referência. Como as redes em módulos não tem como objetivo principal o estudo de medidas topológicas ou a disposição em rede dos genes, foi construída uma interação artificial entre os reguladores e os genes co-expressos dos módulos. Como exemplo, no caso do gene LAMP1 ser o regulador de um módulo formado pelos genes $E G F R, E R B B 3$ e $M Y C$ a estrutura seria montada da seguinte forma: "LAMP1 pp EGFR", "LAMP1 pp ERBB3" e "LAMP1 pp $M Y C$ ". Foram computados os valores preditivos positivos (VPP), valores preditivos negativos (VPN), área sob a curva (AUC, do inglês Area Under the Curve), sensibilidade e especificida. Com relação aos critérios, caso uma aresta seja predita ligando dois genes presentes, mas não conectados, na rede de referência a interação é considerada um falso-positivo. Foram priorizadas as interações TP (do inglês, True Positive - verdadeiro positivo), ou seja, aquelas que foram identificadas pelas metodologias e estavam presentes na rede de referência. Mais detalhadamente:

$$
\begin{gathered}
\text { Sensibilidade }=\frac{T P}{T P+F N} \\
\text { Especificidade }=\frac{T N}{T N+F P} \\
V P P=\frac{T P}{T P+F P} \\
V P N=\frac{T N}{T N+F N}
\end{gathered}
$$

onde TP, FP, TN, FN refere-se aos valores identificados como verdadeiro-positivos, falsopositivos, verdadeiro-negativos e falso-negativos, respectivamente. Foi considerado o intervalo de confiança de $95 \%$. 


\section{RESULTADO}

Os resultados foram organizados em etapas, abordando inicialmente aqueles obtidos pela metodologia de integração de dados (genes selecionados na primeira etapa de integração, seleção de módulos e anotações) e, posteriormente, a validação da metodologia de redes em módulos usando os dados de glioblastoma multiforme (GBM). Na análise de integração dos dados os estudos foram divididos em duas partes: (1) estudos envolvendo alterações no câncer de pênis quando comparadas amostras tumorais e normais e $(\mathbf{2})$ alterações identificadas entre amostras positivas e negativas para a infecção pelo HPV.

Todos os resultados obtidos nas análises de CNA, expressão de mRNA, miRNA, metilação, integração de dados, redes em módulos e validações estão disponíveis no link https:/ / www.dropbox. com/sh/we7179dshpjykzz/qYSjS11CXg, nas pastas correspondentes. Nesta pasta também foram compartilhadas outras figuras resultantes das análises, descrições adicionais das técnicas utilizadas e resultados da validação utilizando amostras de Glioblastoma Multiforme.

\subsection{Análise das Características Clínicas e Patológicas}

O grupo amostral de 31 pacientes com carcinoma de pênis apresentava idade variando entre 30 e 91 anos, prevalência de raça branca (5\%) e primeiro grau escolar (65\%). O seguimento clínico variou de 2 a 37 meses e a história familial de câncer estava presente em $29 \%$ dos pacientes, incluindo familiares com tumores de próstata, intestino, útero, osso, entre outros não especificados. Os dados de fimose, um importante fator de risco para o desenvolvimento de CaPe, não estavam disponíveis para a maioria dos casos avaliados. Aproximadamente $41 \%$ dos pacientes relataram hábito tabagista.

Com relação às características patológicas, o grupo amostral apresentou maior frequência de tumores em estadio clínico III (39\%), grau histológico II $(45,2 \%)$ e estadios patológicos T2 ou T3 (32 e 35\%, respectivamente). Invasões perineural e angiolinfática estavam ausentes em mais de $70 \%$ dos casos e margens cirúrgicas livres foram reportadas para $90 \%$ dos tumores avaliados. Os dados demonstraram tumores medindo entre 2,0 e 6,2 cm no maior eixo.

Os pacientes, em sua maioria, não foram submetidos a terapias neoadjuvantes (77\%), indicando que essas não correspondem as principais formas de tratamento em pacientes com CaPe. O procedimento cirúrgico foi realizado em todos os pacientes para exérese do tumor primário, frequentemente a penectomia parcial. A linfadenectomia foi realizada em 14/31 pacientes avaliados e metástases linfonodais foram encontradas em sete desses casos. Metástases em outros sítios, recidiva da doença e segundo tumor primário foram pouco frequentes no grupo estudado $(10 \%, 16 \%$ e $7 \%$ dos casos, respectivamente).

\subsection{Estudo das Alterações em $\mathrm{CaPe}$}

\subsubsection{Primeira Etapa - Pré-seleção dos Genes}

Considerando o conjunto de 31 amostras de pacientes com carcinoma de pênis nessa etapa foram selecionados os genes que apresentavam as melhores combinações dentre as alterações 
analisadas: alterações no número de cópias genômicas, alteração no nível de metilação do DNA, expressão de transcritos codificadores e expressão de miRNA. Seguindo todas as etapas de seleção discutidas anteriormente (Primeira etapa - Pré-seleção de genes - Materiais e Métodos) foram identificados 73 genes, sendo que todos apresentavam expressão diferencial na comparação entre amostras tumorais e normais de CaPe. Desse total, 40 genes foram identificados com expressão aumentada e 33 com expressão diminuída. Além disso, todos os genes apresentaram algum mecanismo adicional de controle da expressão, como alterações dos níveis de metilação (35 genes hipometilados e 23 hipermetilados). Vinte e quatro genes apresentaram alterações genômicas, sendo 11 ganhos (incluindo uma amplificação) e 13 perdas. Os 16 miRNAs diferencialmente expressos selecionados na etapa de pré-processamento dos dados foram preditos como reguladores de 24 genes, sendo 15 genes alvos de miRNAs com expressão diminuída e 9 genes alvos de miRNAs com expressão aumentada. Os dados foram apresentados na Tabela 6 .

A maior quantidade de genes alterados (15/73) estava mapeada no cromossomo 19. Também foram selecionados genes presentes em maior quantidade nos cromossomos 1 (7/73), $7(11 / 73)$ e 16 (7/73). Diversos candidatos apresentaram funções importantes para o desenvolvimento tumoral (TWIST1, PPARG, RB1, RUNX3, FLI1, MSX1, ZNF415, ZNF160, SIX1, SHOX2, FOXC2, HOXB6, ZNF266) fatores de transcrição (DTX2) e crescimento celular (VEGFB). 


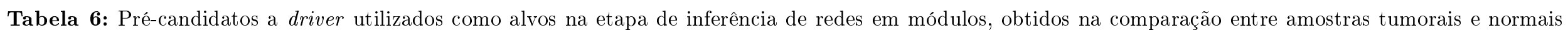

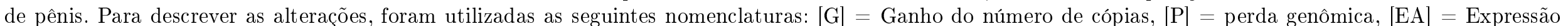

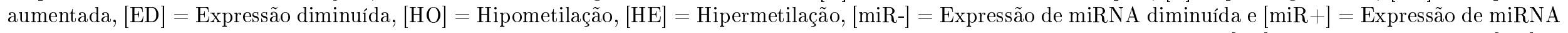

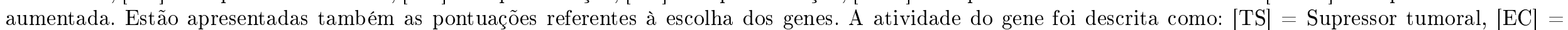
Estabilidade celular, $[\mathrm{ON}]=$ Oncogene e $[\mathrm{PQ}]=$ Proteína quinase e $[\mathrm{TF}]=$ Fator de transcrição.

\begin{tabular}{|c|c|c|c|c|c|}
\hline Gene & Nome & Região & Alteração & miRNA & Função \\
\hline$N R A S$ & Homólogo do oncogene viral RAS do neuroblastoma & $1 \mathrm{p} 13.2$ & $\mathrm{HO} / \mathrm{EA} / \mathrm{miR}-$ & hsa-let-7c, hsa-miR-145 & \\
\hline RUNX3 & RUNT relacionada com fatores de transcrição 3 & $1 \mathrm{p} 36$ & $\mathrm{HO} / \mathrm{EA} / \mathrm{miR}-$ & $h s a-m i R-145, h s a-m i R-484$ & $\mathrm{TF}$ \\
\hline$C A M K 2 N 1$ & Proteína quinase II inibidor 1 relacionada a cálcio/calmodulina & $1 \mathrm{p} 36.12$ & $\mathrm{HE} / \mathrm{ED} / \mathrm{miR}+$ & hsa-miR-20a, hsa-miR-182 & \\
\hline$M E X 3 A$ & Mex-3 homólogo A (C. elegans) & $1 \mathrm{q} 22$ & $\mathrm{HO} / \mathrm{EA} / \mathrm{miR}-$ & $\begin{array}{l}\text { hsa-let- } 7 c, \quad \text { hsa-miR-139-5p, } \\
\text { hsa-miR-320, hsa-miR-484 }\end{array}$ & \\
\hline$A C A A 1$ & Acetil-CoA-aciltransferase 1 & $3 \mathrm{p} 23-\mathrm{p} 22$ & $\mathrm{HO} / \mathrm{EA}$ & & \\
\hline$P P A R G$ & Receptor ativado por proliferadores de peroxissoma gama & $3 \mathrm{p} 25$ & $\mathrm{P} / \mathrm{ED} / \mathrm{miR}+$ & hsa-miR-20a, hsa-miR-130b & TS \\
\hline SHOX2 & Homeobox 2 & $3 q 25-q 26.1$ & $\mathrm{HE} / \mathrm{ED}$ & & $\mathrm{TF}$ \\
\hline TNFSF10 & Superfamília do fator de necrose tumoral, membro 10 & $3 q 26$ & $\mathrm{EA} / \mathrm{HO} / \mathrm{miR}-$ & hsa-let- $7 c$, hsa-miR-139-5p & \\
\hline$S M C 4$ & Manutenção estrutural do cromossomo 4 & $3 q 26.1$ & $\mathrm{HO} / \mathrm{EA}$ & & \\
\hline$M S X 1$ & Msh homeobox 1 & $4 \mathrm{p} 16.3-\mathrm{p} 16.1$ & $\mathrm{P} / \mathrm{HE} / \mathrm{ED}$ & & \\
\hline CLPTM1L & CLPTM1-like & $5 \mathrm{p} 15.33$ & $\mathrm{HO} / \mathrm{EA}$ & & \\
\hline$F E R$ & Fer (relacionado à fps/fes) tirosina quinase & $5 q 21$ & $\mathrm{P} / \mathrm{ED}$ & & $\mathrm{ON}$ \\
\hline NRN1 & Neuritina 1 & $6 \mathrm{p} 25.1$ & $\mathrm{HE} / \mathrm{ED} / \mathrm{miR}+$ & hsa-miR-182 & \\
\hline$P G M 3$ & Fosfoglucomutase 3 & 6q14.1-q15 & $\mathrm{HO} / \mathrm{EA} / \mathrm{miR}-$ & hsa-miR-145, hsa-miR-134 & \\
\hline$A E B P 1$ & AE proteína de ligação 1 & $7 \mathrm{p} 13$ & $\mathrm{HE} / \mathrm{ED}$ & & \\
\hline TWIST1 & Fatores de transcrição hélice-alça-hélice básico 1 & $7 \mathrm{p} 21.2$ & $\mathrm{P} / \mathrm{HE} / \mathrm{ED}$ & & \\
\hline$B Z W^{2}$ & Zíper de leucina básico e W2 domínio 2 & $7 \mathrm{p} 21.2$ & $\mathrm{HO} / \mathrm{EA} / \mathrm{miR}-$ & hsa-let-7c & \\
\hline PRKAR1B & Proteína quinase, dependente de cAmp regulatório, tipo I, beta & 7 pter-p22 & $\mathrm{HO} / \mathrm{EA}$ & & \\
\hline$D T X 2$ & Deltex homólogo 2 (Drosófila) & $7 \mathrm{q} 11.23$ & $\mathrm{HO} / \mathrm{EA} / \mathrm{miR}-$ & hsa-let- $7 c$ & \\
\hline$M E T$ & Met proto-oncogene (Receptor de fator de transcrição de hepatócito) & $7 \mathrm{q} 31$ & $\mathrm{HO} / \mathrm{EA}$ & & \\
\hline$C A V 1$ & Caveolina 1 & $7 \mathrm{q} 31.1$ & $\mathrm{P} / \mathrm{HE} / \mathrm{ED}$ & & \\
\hline$D L C 1$ & Deletado em câncer de fígado 11 & $8 \mathrm{p} 22$ & $\mathrm{P} / \mathrm{ED} / \mathrm{miR}+$ & $\begin{array}{l}\text { hsa-miR-130b, } \quad \text { hsa-miR- } \\
20 a, h s a-m i R-429\end{array}$ & \\
\hline SOX17 & SRY (região de determinação sexual Y)-box 17 & $8 \mathrm{q} 11.23$ & $\mathrm{P} / \mathrm{HE} / \mathrm{ED}$ & & \\
\hline$T S P Y L 5$ & TSPY-like 5 & $8 \mathrm{q} 22.1$ & $\mathrm{HE} / \mathrm{ED}$ & & \\
\hline OSR2 & Odd-skipped related 2 (Drosófila) & $8 \mathrm{q} 22.2$ & $\mathrm{HE} / \mathrm{ED}$ & & $\mathrm{TF}$ \\
\hline $\mathrm{SHC}_{3}$ & SHC (Src homólogo 2) & $9 \mathrm{q} 22.2$ & $\mathrm{HE} / \mathrm{ED} / \mathrm{miR}+$ & $h s a-m i R-130 b$ & \\
\hline
\end{tabular}


$A P B B 1 I P$

TALDO1

$P L C B 3$

VEGFB

$D D X 6$

FLI1

MTRF1

$R B 1$

NID2

CDKN3

SIX1

DIO2

$P M L$

KIAA0101

ZNFr10

SOLH

FOXC2

TRPV1

$D N A J C 7$

HOXB 6

BIRC5

DNMT1

ZNF266

PNPLA6

SBNO2

$G P X_{4}$

WDR18

THOP1

IRGC

C19orf48

KLK5

TMC4
Amiloide beta (A4) família B, membro 1

Transaldolase 1

Fosfolipase C, beta 3

Fator de crescimento do endotélio vascular

DEAD (Asp-Glu-Ala-Asp) box helicase 6

Integração do vírus Friend de leucemia tipo 1

Liberação do fator de tradução mitocondrial 1

Retinoblastoma 1

Nidogen-2 (osteonidogen)

Inibidor quinase 3 ciclina dependente

SIX homeobox 1

Deiodinase, iodotironina, tipo II

Leucemia Promielocítica

Kiaa0101

Proteína Zinc finger 710

Small optic lobes homólogo (Drosófila)

Forkhead box C2 (MFH-1, mesênquima forkhead 1)

Receptor de potencial transiente vanilóide 1

Homólogo Dnaj (Hsp40), subfamília C, membro 7

Homeobox B6

Baculoviral IAP repetir-contendo proteína 5

DNA (citosina-5-)-metiltransferase 1

Proteína zinc finger 266

Patatina fosfolipase contendo proteína 6

Homólogo 2 de Notch Strawberry

Glutationa peroxidase 4

WD domínio de repetição 18

Thimet oligopeptidase 1

Família GTPase relacionada a imunidade

Cromossomo 19 fase de leitura aberta 48

Calicreína relacionada a peptidase 5

Canal 4 transmembrana
$10 \mathrm{p} 12.2$

11p15.5-p15.4

$11 \mathrm{q} 13$

$11 \mathrm{q} 13$

11q23.3

$11 \mathrm{q} 24.1-\mathrm{q} 24.3$

13q14.1-q14.3

$13 q 14.2$

14q21-q22

$14 \mathrm{q} 22$

$14 \mathrm{q} 23.1$

14q24.2-q24.3

$15 \mathrm{q} 22$

$15 \mathrm{q} 22.1$

$15 q 26.1$

$16 \mathrm{p} 13.3$

16q22-16q24

$17 \mathrm{p} 13.3$

$17 q 11.2$

$17 \mathrm{q} 21.3$

$17 \mathrm{q} 25$

$19 \mathrm{p} 13.2$

$19 \mathrm{p} 13.2$

$19 \mathrm{p} 13.2$

19p13.3

$19 \mathrm{p} 13.3$

$19 \mathrm{p} 13.3$

$19 \mathrm{q} 13.3$

19q13.31

$19 \mathrm{q} 13.33$

19q13.3-q13.4

19q13.42
$\mathrm{G} / \mathrm{EA}$

$\mathrm{HO} / \mathrm{EA} / \mathrm{miR}-\quad$ hsa-miR-134

$\mathrm{G} / \mathrm{HO} / \mathrm{EA} / \mathrm{miR}-\quad h s a-m i R-134$

G/ED hsa-miR-484

HE/ED hsa-miR-130b, hsa-miR-

135b, hsa-miR-191, hsa$\operatorname{miR}-484$

$\mathrm{P} / \mathrm{ED} / \mathrm{miR}+\quad$ hsa-miR-429, hsa-miR-130b

$\mathrm{HO} / \mathrm{EA} / \mathrm{miR}-\quad h s a-m i R-320$

$\mathrm{G} / \mathrm{HO} / \mathrm{EA} / \mathrm{miR}-\quad$ hsa-let- $7 \mathrm{c}$

$\mathrm{HE} / \mathrm{ED} /$

$\mathrm{HO} / \mathrm{EA}$

$\mathrm{HE} / \mathrm{ED} / \mathrm{miR}+\quad \mathrm{miR}-429$

$\mathrm{P} / \mathrm{ED}$

$\mathrm{P} / \mathrm{HE} / \mathrm{ED}$

$\mathrm{HO} / \mathrm{EA}$

$\mathrm{HO} / \mathrm{EA} / \mathrm{miR}-$

$\mathrm{G} / \mathrm{HO} / \mathrm{EA}$

$\mathrm{HE} / \mathrm{ED}$

$\mathrm{P} / \mathrm{ED}$

G/EA

$\mathrm{HE} / \mathrm{ED}$

$\mathrm{G} / \mathrm{HO} / \mathrm{EA}$

$\mathrm{AMP} / \mathrm{HO} / \mathrm{EA}$

$\mathrm{ED} / \mathrm{miR}$ -

$\mathrm{HO} / \mathrm{EA}$

$\mathrm{HO} / \mathrm{EA}$

$\mathrm{HE} / \mathrm{ED}$

$\mathrm{HO} / \mathrm{EA}$

$\mathrm{HO} / \mathrm{EA}$

$\mathrm{HO} / \mathrm{EA}$

G/EA

$\mathrm{EA} / \mathrm{miR}-$

$\mathrm{HO} / \mathrm{EA}$ 


\begin{tabular}{|c|c|c|c|c|c|}
\hline ZNF524 & Proteína Zinc finger 524 & 19q13.42 & $\mathrm{HE} / \mathrm{ED}$ & & \\
\hline ZNF415 & Proteína Zinc finger 415 & $19 \mathrm{q} 13.42$ & $\mathrm{HE} / \mathrm{ED}$ & & $\mathrm{TF}$ \\
\hline ZNF160 & Proteína Zinc finger 160 & $19 \mathrm{q} 13.42$ & $\mathrm{HE} / \mathrm{ED}$ & & $\mathrm{TF}$ \\
\hline ZNF341 & Proteína Zinc finger 341 & $20 \mathrm{q} 11.22$ & $\mathrm{HO} / \mathrm{EA} / \mathrm{miR}-$ & hsa-let- $7 c$ & $\mathrm{TF}$ \\
\hline TOMM34 & Translocase de membrana mitocondrial externa 34 & $20 \mathrm{q} 13.12$ & $\mathrm{HO} / \mathrm{EA}$ & & \\
\hline DOK5 & Proteína Docking 5 & $20 \mathrm{q} 13.2$ & $\mathrm{HE} / \mathrm{ED}$ & & \\
\hline CNN2 & Calponina 2 & 21q11.1 & G/EA & & TS \\
\hline$M P S T$ & Mercaptopiruvato sulfurtransferase & $22 \mathrm{q} 13.1$ & $\mathrm{HO} / \mathrm{EA}$ & & \\
\hline SHANK3 & SH3 e múltiplos domínios de anquirina & 22q13.3 & $\mathrm{P} / \mathrm{ED}$ & & $\mathrm{ON} / \mathrm{PQ}$ \\
\hline TBC1D22A & TBC1 membro 22A & 22q13.3 & $\mathrm{HO} / \mathrm{EA}$ & & \\
\hline SAPS2 (PPP6R2) & Proteína fosfatase 6 & $22 \mathrm{q} 13.33$ & $\mathrm{G} / \mathrm{HO} / \mathrm{EA}$ & & \\
\hline$K L H D C 7 B$ & Domínio Kelch contendo 7B & $22 \mathrm{q} 13.33$ & $\mathrm{HO} / \mathrm{EA}$ & & \\
\hline$H S D 17 B 10$ & Hidroxiesteróide desidrogenase tipo 10 (17-beta) & $\mathrm{Xp} 11.2$ & $\mathrm{HO} / \mathrm{EA}$ & & \\
\hline PHF8 & Proteína PHD 8 & $\mathrm{Xp} 11.22$ & $\mathrm{HE} / \mathrm{ED} / \mathrm{miR}+$ & hsa-miR-182, hsa-miR-31 & \\
\hline$D D X 3 Y$ & DEAD (Asp-Glu-Ala-Asp) box polipeptídeo 3 & Yq11 & $\mathrm{P} / \mathrm{ED} / \mathrm{miR}+$ & $\begin{array}{l}\text { hsa-miR-135b, hsa-miR- } \\
\text { 424, hsa-miR-429 }\end{array}$ & $\mathrm{PQ}$ \\
\hline
\end{tabular}


As principais doenças e/ou funções celulares ou moleculares relacionadas aos genes foram apresentadas na Tabela $7\left(p<5 \times 10^{-5}\right)$. Os resultados mostraram um grande número de moléculas alteradas envolvidas em vias alteradas pelo câncer (AEBP1, DDX6, DNMT1, HOXB6, HSD17B10, MET, NRAS, PML, PPARG, RB1, TRPV1, CAV1, DLC1, NID2, RUNX3 e TWIST1) e predominância de genes com funções relacionadas com ciclo celular (CAV1, MET, NRAS, PML, PPARG, RB1 e CAMK2N1), crescimento e proliferação celular (AEBP1, CAV1, FLI1, MET, NRAS, OSR2, PML, PPARG, RB1 e TWIST1) e morte celular (DNMT1, FLI1, GPX4, MET, NRAS, PML, PPARG, RB1, RUNX3, TWIST1, CAMK2N1, CAV1, FER, HSD17B10, MSX1, PNPLA6, SHC3 e SIX1).

Tabela 7: Genes enriquecidos para diversas funções e doenças. Para o enriquecimento dos 73 genes nas categorias descritas foi considerado um $p<5 \times 10^{-5}$.

\begin{tabular}{|c|c|c|}
\hline Categoria & P-Valor & Genes \\
\hline Morte celular & $2,13 \times 10^{-6}$ & $\begin{array}{l}\text { DNMT1, FLI1, GPX4, MET, NRAS, } \\
\text { PML, PPARG, RB1, RUNX3, TWIST1, } \\
\text { CAMK2N1, CAV1, FER, HSD17B10, } \\
\text { MSX1, PNPLA6, SHC3, SIX1 }\end{array}$ \\
\hline Câncer & $2,25 \times 10^{-6}$ & $\begin{array}{l}\text { AEBP1, DDX6, DNMT1, HOXB6, } \\
\text { HSD17B10, MET, NRAS, PML, PPARG, } \\
\text { RB1, TRPV1, CAV1, DLC1, NID\&, } \\
\text { RUNX3, TWIST1 }\end{array}$ \\
\hline Desenvolvimento celular & $3,07 x 10^{-6}$ & $\begin{array}{l}\text { CAV1, MSX1, RB1, RUNX3, SIX1, } \\
\text { TWIST1 }\end{array}$ \\
\hline Crescimento celular e proliferação do câncer & $4,44 \times 10^{-6}$ & CAV1, FLI1, NRAS, PML, PPARG, RB1 \\
\hline Ciclo celular & $5,50 \times 10^{-6}$ & $\begin{array}{l}\text { CAV1, MET, NRAS, PML, PPARG, RB1, } \\
\text { CAMK2N1 }\end{array}$ \\
\hline Desenvolvimento do tecido conectivo & $5,81 x 10^{-6}$ & $\begin{array}{l}A E B P 1, \quad C A V 1, \quad M E T, \quad N R A S, \quad P M L, \\
P P A R G, R B 1\end{array}$ \\
\hline Crescimento e proliferação celular & $6,27 x 10^{-6}$ & $\begin{array}{l}\text { AEBP1, CAV1, FLI1, MET, NRAS, } \\
\text { OSR2, PML, PPARG, RB1, TWIST1 }\end{array}$ \\
\hline Morfologia tumoral & $8,24 x 10^{-6}$ & $M E T, P P A R G, R B 1$ \\
\hline Expressão gênica & $2,20 \times 10^{-5}$ & $\begin{array}{l}\text { AEBP1, CAV1, DNMT1, FLI1, } M E T, \\
M S X 1, \quad \text { OSR2, PML, PPARG, RB1, } \\
\text { RUNX3, SBNO2, SIX1, SOLH, TWIST1 }\end{array}$ \\
\hline
\end{tabular}

Os genes também foram enriquecidos para vias suscetíveis a compostos caracterizados por sua toxicidade, usando uma abordagem toxicogenômica com dados disponíveis no CTD (Comparative Toxicogenomics Database, disponível em http://ctdbase.org/). Essa estratégia permitiu identificar atividades específicas dos genes, selecionados na primeira etapa de integração, como biomarcadores tecido-específicos. Como apresentado na Tabela 8, alguns grupos de genes foram relacionados com vias importantes como sinalização do TGF (NRAS e RUNX3), p53 (RB1 e $P M L)$, NF-kappa $\beta$ (NRAS), ativação do RAR (PRKAR1B e PML) e via de proliferação celular (PPARG, MET, RB1, CAV1, PML e DLC1). 
Tabela 8: Genes enriquecidos para vias susceptíveis a efeitos toxicológicos, possibilitando a identificação de possíveis biomarcadores. Para escolha das vias significativas foi considerado $p<10^{-} 3$

\begin{tabular}{|c|c|c|}
\hline Vias biológicas & P-Valor & Genes \\
\hline Metabolismo de ácido graxo & $1,04 \times 10^{-4}$ & HSD17B10, ACAA1 \\
\hline Resposta ao stress oxidativo via NRF2 & $1,08 \times 10^{-4}$ & NRAS, DNAJCY \\
\hline Aumento a danos no fígado & $1,16 \times 10^{-4}$ & MET \\
\hline Hipertrofia cardíaca & $1,18 \times 10^{-4}$ & SIX1, CAV1 \\
\hline Necrose renal/morte celular & $1,27 \times 10^{-4}$ & $P P A R G, C A V 1$ \\
\hline Aumento a danos da mitocôndria & $1,38 \times 10^{-4}$ & $R B 1$ \\
\hline Fibrose cardíaca & $1,38 \times 10^{-4}$ & $C A V 1$ \\
\hline Hiperproliferação hepática & $1,59 \times 10^{-4}$ & MET, TWIST1 \\
\hline $\begin{array}{l}\text { Sinalização de metabolismo de xenobióti- } \\
\text { cos }\end{array}$ & $1,80 \times 10^{-4}$ & NRAS, PNPLA6, DNAJC7 \\
\hline Sinalização do TGF & $2,17 \times 10^{-4}$ & $R U N X 3, N R A S$ \\
\hline Sinalização do p53 & $2,23 \times 10^{-4}$ & $R B 1, P M L$ \\
\hline Ativação PPAR/RXR & $2,91 \times 10^{-4}$ & NRAS, ACAA1, PRKAR1B, PLCB3 \\
\hline Aumento da esteatose hepática & $3,72 \times 10^{-4}$ & $P P A R G, C A V 1, T R P V 1$ \\
\hline $\begin{array}{l}\text { Mecanismo de regulação gênica por meio } \\
\text { da proliferação de peroxissomos via PPAR }\end{array}$ & $4,12 \times 10^{-4}$ & $P P A R G, R B 1, N R A S, P R K A R 1 B$ \\
\hline Proliferação celular & $4,48 \times 10^{-4}$ & $P P A R G, M E T, R B 1, C A V 1, P M L, D L C 1$ \\
\hline Colestase hepática & $3,25 \times 10^{-3}$ & PRKAR1B \\
\hline Aumento da proliferação renal & $3,97 \times 10^{-3}$ & MET \\
\hline $\begin{array}{l}\text { Diminuição do potencial transmembranico } \\
\text { da mitocôndria }\end{array}$ & $4,13 \times 10^{-3}$ & $T R P V 1$ \\
\hline Ativação TR/RXR & $4,97 \times 10^{-3}$ & DIO2 \\
\hline Ativação FXR/RXR & $5,10 \times 10^{-3}$ & $P P A R G$ \\
\hline Ativação PXR/RXR & $6,01 \times 10^{-3}$ & PRKAR1B \\
\hline $\begin{array}{l}\text { Ciclo celular: regulação do checkpoint da } \\
\text { fase } \mathrm{G} 1 / \mathrm{S}\end{array}$ & $6,20 \times 10^{-3}$ & $R B 1$ \\
\hline Stress oxidativo & $6,54 \times 10^{-3}$ & $G P X_{4}$ \\
\hline $\begin{array}{l}\text { Aumento do potencial transmembranico } \\
\text { da mitocôndria }\end{array}$ & $6,76 \times 10^{-3}$ & $P P A R G$ \\
\hline Ativação do RAR & $7,31 x 10^{-3}$ & $P R K A R 1 B, P M L$ \\
\hline Sinalização NF-kappaB & $7,63 \times 10^{-3}$ & NRAS \\
\hline $\begin{array}{l}\text { Sinalização do receptor aril hidrocarbo- } \\
\text { neto }\end{array}$ & $8,21 \times 10^{-3}$ & $R B 1$ \\
\hline Disfunção mitocondrial & $8,26 \times 10^{-3}$ & $\mathrm{H} S D 17 B 10, G P X_{4}$ \\
\hline Necrose renal/morte celular & $9,67 \times 10^{-3}$ & $M E T, R B 1$ \\
\hline
\end{tabular}

Para a identificação de possíveis reguladores dos 73 genes identificados foi utilizado o pipeline proposto em "Identificação de possíveis reguladores - Materiais e Métodos". Foram identificados genes candidatos a reguladores como os fatores de transcrição TP53, NFYB, ETS1, JUN, EGR1 e CREB1 (Tabela 9). Também foram identificados os miRNAs hsa-miR-199a-5p, hsa-let-7a$5 p$ e hsa-miR-133, descritos em literatura como reguladores de genes importantes como CAV1, DNMT1, PPARG e RB1. Dentre os 19 genes identificados, 13 estão presentes na matriz de genes diferencialmente expressos, identificados como possíveis passengers ou selecionados na primeira etapa da metodologia de integração de dados. Dentre os genes avaliados, foram identificados mais frequentemente envolvidos com os candidatos a reguladores o TWIST1 (8 vezes), MET (8 vezes), PPARG (8 vezes), CAV1 (8 vezes) e $R B 1$ (10 vezes). 
Tabela 9: Possíveis candidatos a reguladores. A partir de informações disponíveis na literatura foram identificados genes significativamente descritos como possíveis reguladores dos genes selecionados na primeira etapa da metodologia de integração de dados. É possível destacar o gene $R B 1\left(2.17 x 10^{-7}\right)$, possível regulador dos genes DIO2, DNMT1, KIAA0101, MET, MSX1 e PPARG. Esse gene também foi descrito com função de auto regulação. $[\mathrm{EA}]=$ expressão aumentada, $[\mathrm{ED}]=$ expressão diminuída.

\begin{tabular}{|c|c|c|c|c|}
\hline Reguladores & CaPe (expressão) & Tipo molecular & P-Valor & Genes relacionados \\
\hline$R B 1$ & $\mathrm{EA}$ & Regulador da transcrição & $2,17 \times 10^{-7}$ & $\begin{array}{l}\text { DIO2, DNMT1,KIAA0101, } \\
M S X 1, \text { PPARG }\end{array}$ \\
\hline hsa-mir-133 & & miRNA & $8,31 x 10^{-6}$ & DNMT1, MET, PPARG \\
\hline TP53 & EA & Regulador da transcrição & $8,36 \times 10^{-6}$ & $\begin{array}{l}\text { CAV1, DNMT1, KIAA0101, MET, } \\
\text { NID2, PGM3, PML, PPARG, RB1, } \\
\text { SMC4, THOP1, TRPV1, TWIST1 }\end{array}$ \\
\hline$h s a-m i R-199 a-5 p$ & & miRNA maduro & $2,58 \times 10^{-5}$ & $\begin{array}{llll}C A V 1, & D D X 3 Y, & D D X 6, & D L C 1, \\
H O X B 6, & P N P L A 6, & R U N X 3, & S M C 4, \\
Z N F 710 & & & \end{array}$ \\
\hline$H R A S$ & EA & Enzima & $4,59 \times 10^{-5}$ & $\begin{array}{l}C A V 1, \quad D N M T 1, \quad H O X B 6, \quad M E T, \\
\text { NID2, PML, TRPV1, TWIST1 }\end{array}$ \\
\hline$I L 6$ & EA & Citocinas & $1,23 \times 10^{-4}$ & $\begin{array}{l}\text { DNMT1, FLI1, KIAA0101, MET, } \\
\text { NRAS, PPARG, RB1, SBNO2, } \\
\text { TWIST1 }\end{array}$ \\
\hline$N F Y B$ & EA & Regulador da transcrição & $1,57 x 10^{-4}$ & $\begin{array}{l}C A V 1, \quad K I A A 0101, \quad P G M 3, \\
T B C 1 D 22 A, T W I S T 1, Z N F 524\end{array}$ \\
\hline FGF2 & ED & Crescimento celular & $1,85 \times 10^{-4}$ & $\begin{array}{l}\text { CAV1, MET, MSX1, PPARG, RB1, } \\
\text { TWIST1 }\end{array}$ \\
\hline PD98059 & & Inibidor quinase - químico & $2,03 \times 10^{-4}$ & $\begin{array}{l}C A V 1, \quad \text { DIO2, } \quad \text { DNMT1, MET, } \\
\text { PPARG, RB1 }\end{array}$ \\
\hline$T G F B 1$ & EA & Crescimento celular & $2,47 \times 10^{-4}$ & $\begin{array}{l}C A V 1, \quad D N M T 1, \quad F L I 1, \quad H S D 17 B 10, \\
M E T, \quad O S R 2, \quad P M L, \quad P P A R G, \quad R B 1, \\
R U N X 3, \quad S B N O 2, \quad S M C 4, \quad S O L H, \\
T W I S T 1\end{array}$ \\
\hline$S W I-S N F$ & & Complexo & $2,50 \times 10^{-4}$ & $M E T, P P A R G$ \\
\hline ETS1 & EA & Regulador da transcrição & $2,64 x 10^{-4}$ & $\begin{array}{l}\text { CAV1, FLI1, MET, PML, RUNX3, } \\
\text { TWIST1 }\end{array}$ \\
\hline$h s a-l e t-7 a-5 p$ & & miRNA maduro & $2,70 \times 10^{-4}$ & $\begin{array}{l}\text { BZW2, DLC1, DTX2, } \text { MEX3A, } \\
\text { NID2, NRAS, PHF8, RB1, TSPYL5, } \\
\text { ZNF341, ZNF710 }\end{array}$ \\
\hline CHUK & EA & Quinase & $2,81 x 10^{-} 4$ & $A E B P 1, D N M T 1, R B 1, T W I S T 1$ \\
\hline$J U N$ & ED & Regulador da transcrição & $3,10 \times 10^{-4}$ & $\begin{array}{l}\text { CAV1, DIO2, DNMT1, MET, } \\
\text { TWIST1 }\end{array}$ \\
\hline PCM1 & ED & Outro & $5,21 x 10^{-4}$ & $R B 1$ \\
\hline P38 & & Grupo & $5,43 x 10^{-4}$ & $C A V 1, D I O 2, P M L, P P A R G, R B 1$ \\
\hline$E G R 1$ & ED & Regulador da transcrição & $6,89 \times 10^{-4}$ & $C A V 1, P P A R G, R B 1$ \\
\hline$C R E B 1$ & EA & Regulador da transcrição & $7,82 x 10^{-4}$ & DIO2, PPARG, RB1, THOP1 \\
\hline
\end{tabular}

\subsubsection{Seleção de Módulos}

Após 100 simulações, o programa de atribuição dos genes identificados na primeira etapa como possíveis reguladores de conjuntos de genes co-expressos identificou 125 módulos que passaram por todos os critérios de seleção, conforme explicado em "Redes em módulos - Materiais e Métodos". É possível observar na Figura 13 que aproximadamente 100 módulos foram identificados com p-valor igual à zero. Os módulos que não passaram por esse critério não foram selecionados para as etapas seguintes. 


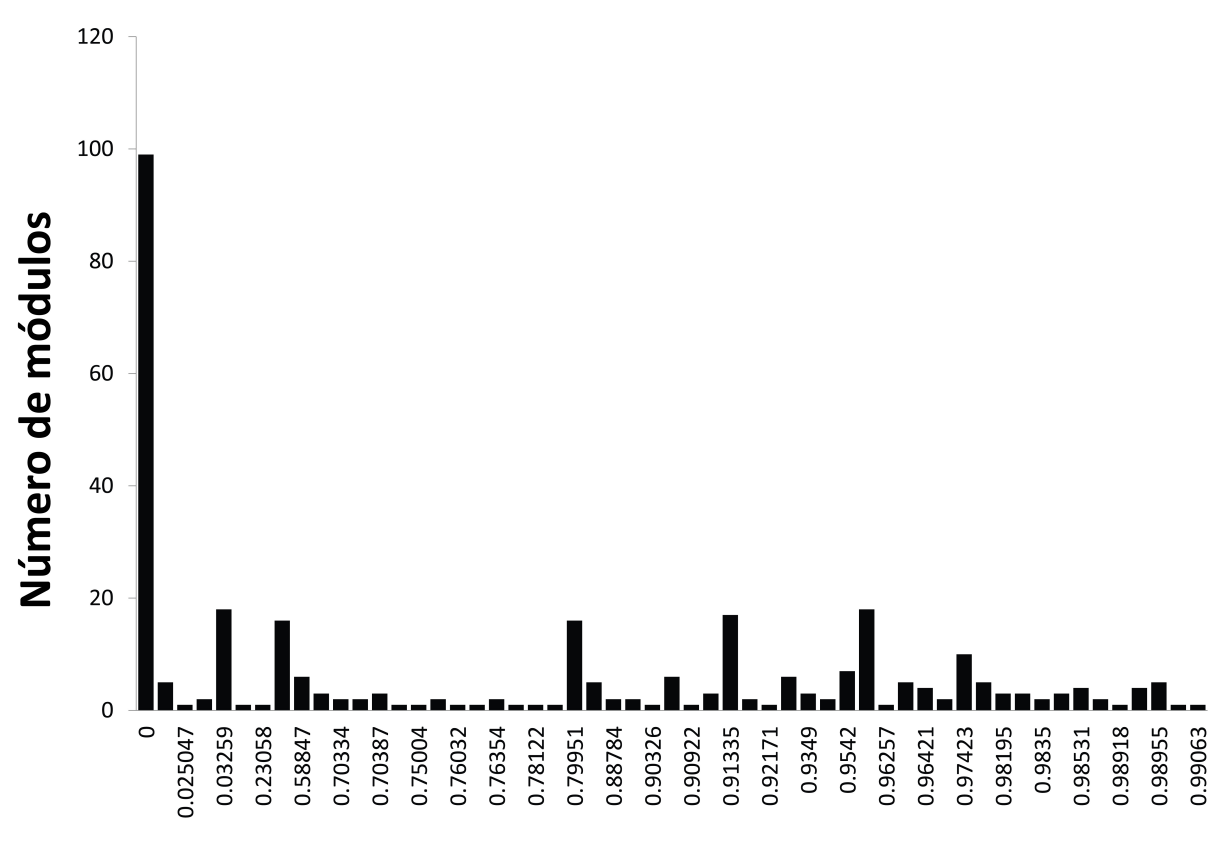

P-Valor

Figura 13: Representação dos módulos identificados de acordo com a significância estatística definida por $\mathrm{p}<0,05$. Seleção de módulos a partir dos alvos pré-selecionados em amostras de carcinoma de pênis. É possível observar que após 100 simulações a maior concentração de módulos permaneceu próxima de zero.

\subsubsection{Atribuição de Genes como Reguladores dos Módulos}

A partir dos 73 genes atribuídos como possíveis reguladores dos 125 módulos foram identificados 17 genes candidatos a drivers, selecionados para análises posteriores. O cromossomo 7 apresentou a maior quantidade de candidatos (TWIST1, DTX2 e CAV1), seguido pelos cromossomos 1 (NRAS e RUNX3), 3 (PPARG e TNFSF10), 8 (DLC1 e SOX17) e 11 (PLCB3 e FLI1) Dos 17 genes, 12 apresentaram alterações genômicas envolvendo ganhos ou amplificação de cópias (PLCB3, RB1, DNMT1 e BIRC5) e deleções (SOX17, TWIST1, FLI1, PML, PPARG, MSX1, CAV1, DLC1), 14 genes apresentaram alterações nos níveis de metilação, com hipermetilação para os genes CAV1, PML, MSX1, NRN1, TWIST1 e SOX17 e hipometilação para RB1, TNFSF10, PLCB3, BIRC5, DNMT1, NRAS, RUNX3 e DTX2). Foram identificados 10 genes candidatos preditos como alvos de miRNAs, sendo os genes TNFSF10, PLCB3, RB1, NRAS, RUNX3 e DTX2 regulados por miRNAs com expressão diminuída e FLI1, DLC1, NRN1 e PPARG regulados por miRNAs com expressão aumentada. Também foram identificados seis genes supressores tumorais ( $P L C B 3, R B 1, P M L, R U N X 3, C A V 1$ e SOX17) e três oncogenes (BIRC5, DNMT1, NRAS). Também foi identificada uma média de 6 passengers por módulo, formado em média por 24 genes co-expressos. Os dados foram apresentados na Tabela 10. 
Tabela 10: Seleção de 17 possíveis candidatos a driver pela metodologia de integração de dados. Para descrever as alterações, foram utilizadas as seguintes nomenclaturas: $[\mathrm{G}]=$ Ganho do número de cópias, $[\mathrm{P}]=$ perda genômica, $[\mathrm{EA}]=$ Expressão aumentada, $[\mathrm{ED}]=$ Expressão diminuída, $[\mathrm{HO}]=$ Hipometilação, $[\mathrm{HE}]$

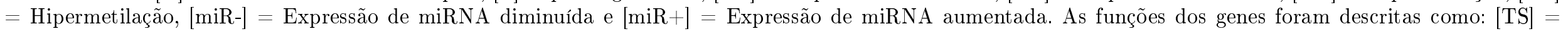
Supressor tumoral e $[\mathrm{ON}]=$ Oncogene.

\begin{tabular}{|c|c|c|c|c|c|c|c|}
\hline Gene & Região & Módulo & Módulos (nome) & Alteração & $* \% \mathrm{PPI}$ & Função & № passengers $\mid$ genes módulo \\
\hline$B I R C 5$ & $17 q 25$ & 2 & GO:0008283 (Crescimento celular) & $\mathrm{G} / \mathrm{HO} / \mathrm{EA}$ & 30 & $\mathrm{ON}$ & $10 / 22$ \\
\hline$C A V 1$ & $7 \mathrm{q} 31.1$ & 25 & GO:0030154 (Diferenciação celular) & $\mathrm{P} / \mathrm{HE} / \mathrm{ED}$ & 16 & TS & $5 / 25$ \\
\hline$D N M T 1$ & $19 \mathrm{p} 13.2$ & 0 & GO:0006355 (Regulação da transcrição) & $\mathrm{AMP} / \mathrm{HO} / \mathrm{EA}$ & 31,8 & & $7 / 22$ \\
\hline$D T X 2$ & $7 q 11.23$ & 3 & GO:0007219 (Via de sinalização do NOTCH) & $\mathrm{HO} / \mathrm{EA} / \mathrm{miR}-$ & 30 & & $9 / 30$ \\
\hline FLI1 & $11 \mathrm{q} 24.1-\mathrm{q} 24.3$ & 35 & GO:0045499 (Regulação da transcrição) & $\mathrm{P} / \mathrm{ED} / \mathrm{miR}+$ & 25 & & $5 / 20$ \\
\hline$M S X 1$ & $4 \mathrm{p} 16.2$ & 5 & $\begin{array}{l}\text { GO:0000122 (Regulação negative da transcrição a } \\
\text { partir do promotor da RNA polimerase) }\end{array}$ & $\mathrm{P} / \mathrm{HE} / \mathrm{ED}$ & 20 & & $5 / 25$ \\
\hline$D L C 1$ & $8 \mathrm{p} 22$ & 18 & GO:0016337 (Adesão célula-célula) & $\mathrm{P} / \mathrm{ED} / \mathrm{miR}+$ & 25 & & $5 / 20$ \\
\hline TNFSF10 & $3 q 26$ & 43 & GO:0009987 (Processo celular) & $\mathrm{EA} / \mathrm{HO} / \mathrm{miR}-$ & 25 & & $6 / 24$ \\
\hline$N R A S$ & $1 \mathrm{p} 13.2$ & 9 & GO:0043066 (Regulação negativa da apoptose) & $\mathrm{HO} / \mathrm{EA} / \mathrm{miR}-$ & 35 & $\mathrm{ON}$ & $7 / 20$ \\
\hline NRN1 & $6 \mathrm{p} 25.1$ & 12 & $\begin{array}{l}\text { GO:0007399 (Desenvolvimento do sistema ner- } \\
\text { voso) }\end{array}$ & $\mathrm{HE} / \mathrm{ED} / \mathrm{miR}+$ & 15 & & $4 / 20$ \\
\hline$P L C B 3$ & $11 q 13$ & 13 & GO:0035556 (Transmissão de sinal intracelular) & $\mathrm{G} / \mathrm{HO} / \mathrm{EA} / \mathrm{miR}-$ & 29,1 & TS & $7 / 24$ \\
\hline$P M L$ & $15 q 22$ & 14 & GO:0006351 (Transcrição dependente de DNA) & $\mathrm{P} / \mathrm{HE} / \mathrm{ED}$ & 25 & TS & $10 / 40$ \\
\hline$P P A R G$ & $3 \mathrm{p} 25$ & 15 & GO:0006350 (Transcrição) & $\mathrm{P} / \mathrm{ED} / \mathrm{miR}+$ & 20 & & $3 / 15$ \\
\hline$R B 1$ & $13 q 14.2$ & 19 & GO:0007049 (Ciclo celular) & $\mathrm{G} / \mathrm{HO} / \mathrm{EA} / \mathrm{miR}-$ & 16,6 & TS & $5 / 24$ \\
\hline RUNX3 & $1 \mathrm{p} 36$ & 21 & GO:0042981 (Regulação da apoptose) & $\mathrm{HO} / \mathrm{EA} / \mathrm{miR}-$ & 25 & TS & $6 / 24$ \\
\hline SOX17 & $8 q 11.23$ & 23 & GO:0007582 (Processo fisiológico) & $\mathrm{P} / \mathrm{HE} / \mathrm{ED}$ & 25 & TS & $7 / 28$ \\
\hline$T W I S T 1$ & $7 \mathrm{p} 21.2$ & 1 & $\begin{array}{l}\text { GO:0045892 (Regulação negativa da transcrição } \\
\text { DNA dependente) }\end{array}$ & $\mathrm{P} / \mathrm{HE} / \mathrm{ED}$ & 34,6 & & $9 / 26$ \\
\hline
\end{tabular}


O gene NRAS atribuído como regulador do módulo 9 (7/20 passengers) apresentou a maior frequência de interações proteína-proteína com os genes presentes no módulo (35\%) seguido pelos genes TWIST1 (módulo 1, 9/26 passengers e 34,6\% de PPI) e DNMT1 (módulo 0, 7/22 passengers e 31,8\% de interações proteína-proteína). Já o gene $P M L$, mapeado na região 15q22 e regulador do módulo 14, apresentou a maior quantidade de genes passengers no módulo (10/40), seguido pelos genes DTX2 (regulador do módulo 3, mapeado na região 7q11.23, com 9/30 genes passengers) e TWIST1, mapeado na região 7 p21.2 e regulador do módulo 1 que possui 9/26 genes passengers.

Uma particularidade do processo de atribuição dos genes candidatos como reguladores dos módulos é que um gene pode ser inferido como regulador de mais de um módulo. Os critérios de seleção de módulos utilizados nesse estudo possibilitam a escolha de um único módulo com maior associação com o regulador (candidato a driver), podendo apresentar maior relevância biológica no desenvolvimento do carcinoma de pênis devido a maior quantidade de genes passengers no módulo e por possuir maior interação física entre os genes co-expressos e o candidato a regulador. Nesse caso, a Tabela 11 apresenta os módulos significativos regulados pelos genes BIRC5, DNMT1, FLI1, PML, PPARG, RB1, SOX17, TNFSF10 e TWIST1. É possível observar que o gene BIRC5 foi identificado como regulador dos módulos 2, 4 e 6, porém de acordo com os critérios de seleção, foi atribuído como regulador do módulo 2, com uma frequência de $36,3 \%$ de genes passengers no módulo $(8 / 22)$ e $p=1,5 \times 10^{-2}$ para o enriquecimento no processo de crescimento celular. Já a gene $S O X 17$ foi atribuído apenas como regulador do módulo 23, onde foram identificados $25 \%$ de passengers $(7 / 28)$ e significância de $p=7,9 x 10^{-3}$ para enriquecimento no processo fisiológico.

Assim como descrito para o gene SOX17, os genes PML, FLI1 e TNFSF10 também foram identificados como reguladores exclusivos de apenas um módulo. O gene $P M L$ foi atribuído como regulador do módulo 14 , com frequência de $25 \%$ de passengers $(10 / 40)$ e enriquecido significativamente para transcrição (GO:0006351, $p=6,7 \times 10^{-3}$ ). Já o gene TNFSF10 foi enriquecido para processo celular (GO:0009987, $p=7,7 \times 10^{-3}$ ) e atribuído como regulador do módulo 78 que agrupou 26 genes co-expressos, sendo três passengers. O gene candidato a driver FLI1 foi enriquecido para regulação da transcrição (GO:0045499, $p=5,7 \times 10^{-3}$ ) e apresentou um frequência de passengers de $25 \%$ (5/20). Os genes TWIST1, PPARG e RB1 foram atribuídos, a princípio, como reguladores de mais de um módulo. Porém, foram selecionados apenas os módulos 1, 15 e 19 respectivamente, devido a maior quantidade de genes passengers e pela frequência de PPI maior que $10 \%$.

A Figura 14 apresenta o resultado da atribuição do gene BIRC5 como regulador do módulo 2, onde é possível observar que 10/22 genes do módulo apresentavam função diretamente relacionada ao crescimento celular, sendo oito deles identificados como possíveis passengers. Ainda, a Figura apresenta outros processos relacionados como os genes, como a via de sinalização $J A K$ STAT e processos biológicos. Com relação às interações proteína-proteína, destacam-se os genes CDK1, CDK4, SOCS1, ETV6, CASP9 e SOX1. Entre os possíveis passengers foram encontrados os genes SLC24A3, SOCS1, S100A11, MSH6,ETV6, SOX1, TOMM34 e RASA1. A rede apresentada na Figura 14 demonstra a interação existente entre os genes do módulo e o regulador. O cálculo TF*IDF resultou em alta pontuação para o termo ("nome do gene"), sugerindo que a alta conectividade encontrada está relacionada à grande quantidade de citações do termo. 


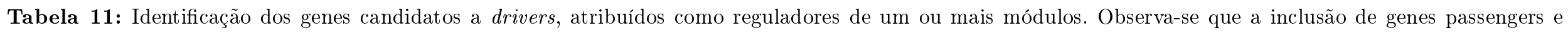

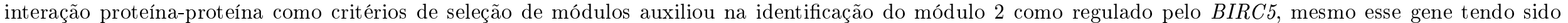

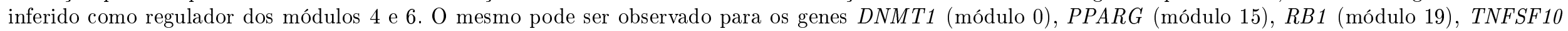

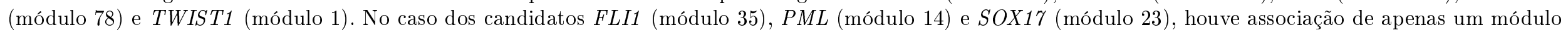
com cada gene.

\begin{tabular}{|c|c|c|c|c|c|c|}
\hline Processo Biológico & P-Valor & Candidatos a drivers & GO ID & Módulo & Passengers/Módulo & $\%$ PPI \\
\hline Manutenção & $5,3 x 10^{-3}$ & BIRC5 & GO:0008151 & 4 & $2 / 23$ & 8,7 \\
\hline Oncogêneses & $9,4 x 10^{-3}$ & $B I R C 5$ & GO:0007048 & 6 & $1 / 15$ & 6,7 \\
\hline Crescimento celular & $1,5 \times 10^{-2}$ & BIRC5 & GO:0008283 & 2 & $8 / 22$ & 30 \\
\hline Regulação da transcrição & $5,1 x 10^{-3}$ & $D N M T 1$ & GO:0006355 & $\mathbf{0}$ & $7 / 22$ & 31,8 \\
\hline Regulação negativa da transcrição & $7,4 x 10^{-3}$ & $D N M T 1$ & GO:0016481 & 7 & $1 / 24$ & 4,2 \\
\hline Transcrição pelo promotor da polimerase II & $2,3 x 10^{-2}$ & $D N M T 1$ & GO:0006366 & 66 & $2 / 25$ & 8,0 \\
\hline Regulação da transcrição & $5,7 \times 10^{-4}$ & FLI1 & GO:0045499 & 35 & $5 / 20$ & 25 \\
\hline Transcrição dependente de DNA & $6,7 x 10^{-4}$ & $P M L$ & GO:0006351 & 14 & $10 / 40$ & 25 \\
\hline Transcrição & $8,3 x 10^{-4}$ & PPARG & GO:0006350 & 15 & $3 / 15$ & 20 \\
\hline Metabolismo de ácido nucleico & $8,8 x 10^{-4}$ & PPARG & GO:0006139 & 43 & $0 / 15$ & 0,0 \\
\hline Regulação da transcrição pelo promotor da polimerase II & $4,4 \times 10^{-2}$ & $R B 1$ & GO:0006357 & 8 & $1 / 13$ & 7,7 \\
\hline Ciclo celular & $2,3 x 10^{-2}$ & $R B 1$ & GO:0007049 & 19 & $4 / 24$ & 16,6 \\
\hline Processo fisiológico & $7,9 x 10^{-3}$ & $S O X 17$ & GO:0007582 & 23 & $7 / 28$ & 25 \\
\hline Processo celular & $7,7 x 10^{-3}$ & TNFSF10 & GO:0009987 & 78 & $3 / 26$ & 11,5 \\
\hline Regulação negativa da transcrição a partir do promotor da polimerase II & $3 x 10^{-3}$ & TWIST1 & GO:0000122 & 41 & $1 / 33$ & 3,0 \\
\hline Regulação negativa da transcrição DNA dependente & $4,6 x 10^{-3}$ & TWIST1 & GO:0045892 & 1 & $9 / 26$ & 34,6 \\
\hline Desenvolvimento do esqueleto & $1,9 \times 10^{-2}$ & $T W I S T 1$ & GO:0001501 & 42 & $0 / 17$ & 0,0 \\
\hline
\end{tabular}

*em negrito foram representados os módulos selecionados pelos critérios estabelecidos na etapa de integração de dados. PPI = interação proteína-proteína, GO ID = Código de identificação do processo biológico no banco de dados Gene Ontology (disponível em http://www.geneontology.orgâ̆ Ŏ). 
módulo 5. Crescimento celular

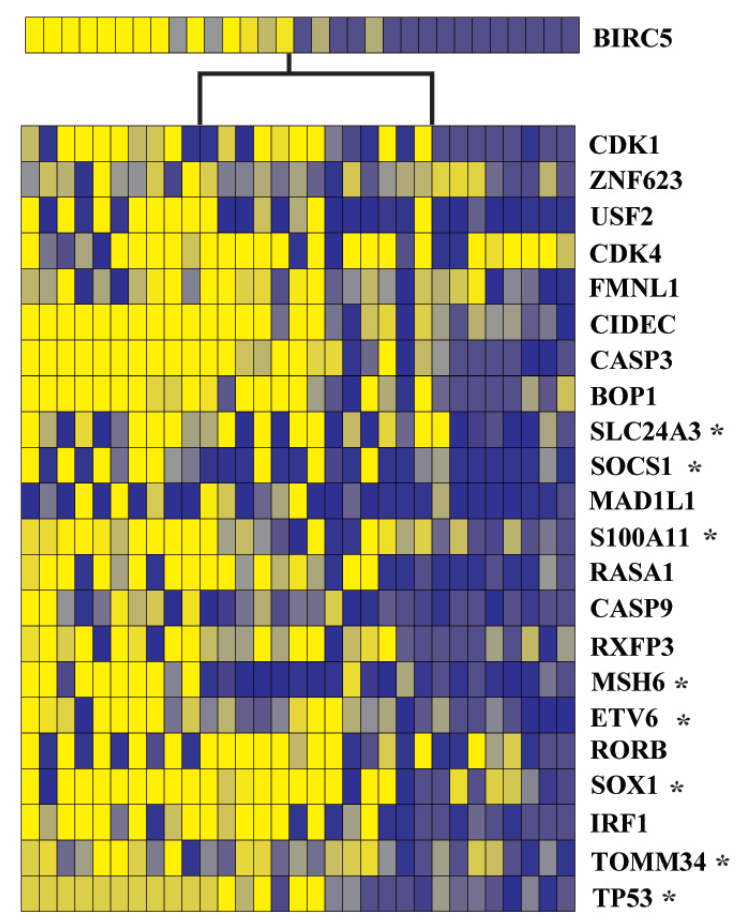

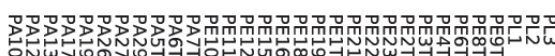

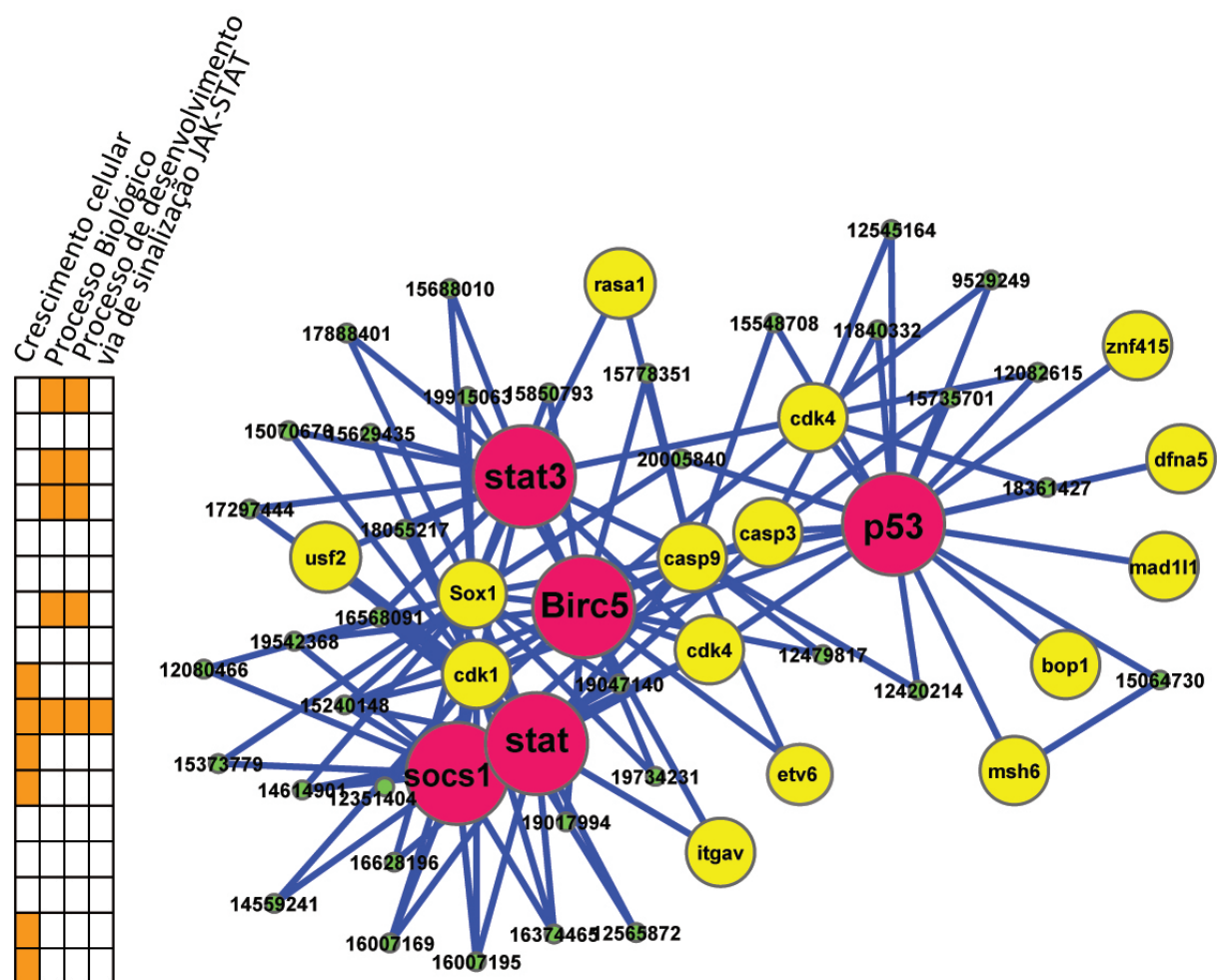

MENOS REPRESENTATIVOS

Expressão aumentada Expressão diminuída

Figura 14: Representação da associação entre o regulador BIRC5 e o módulo enriquecido para crescimento celular. Afigura apresenta a matriz de expressão (heatmap) com todas as amostras de câncer de pênis utilizadas nesse estudo e os asteriscos indicam genes identificados como passengers. A função de cada gene pode ser observada na cor laranja, e atribuída a quatro processos biológicos. Nesse caso, o módulo foi enriquecido para via de crescimento celular, com dez genes relacionados a essa função, sendo oito deles identificados comopassengers. A rede representa a interação entre os genes do módulo com o regulador BIRC5, além das interações desses genes com os estudos mais relevantes disponíveis na literatura, representados pelo código de acesso pelo PUBMED. 
As interações entre os candidatos a drivers e os genes pertencentes aos módulos correspondentes foram dispostas em forma de rede, permitindo a identificação de possíveis interações existentes. Para essa representação, foram obtidas as interações proteína-proteína de cada gene regulador utilizando os bancos de dados indicados em "Mecanismos para seleção de módulos - Materiais e Métodos". Especificamente para o estudo entre amostras tumorais e normais de carcinoma de pênis, a Figura 15 apresenta uma forte interação estabelecida entre os módulos regulados pelos genes $C A V 1, P L C B 3, T W I S T 1$ e RB1. O gene BIRC5 também apresentou uma forte interação com os candidatos $D L C 1$ e FLI1. No caso do gene $S O X 17$, identificado com baixos níveis de expressão de transcritos codificadores e altos níveis de metilação da região promotora, não foi observada interação com nenhum outro candidato.

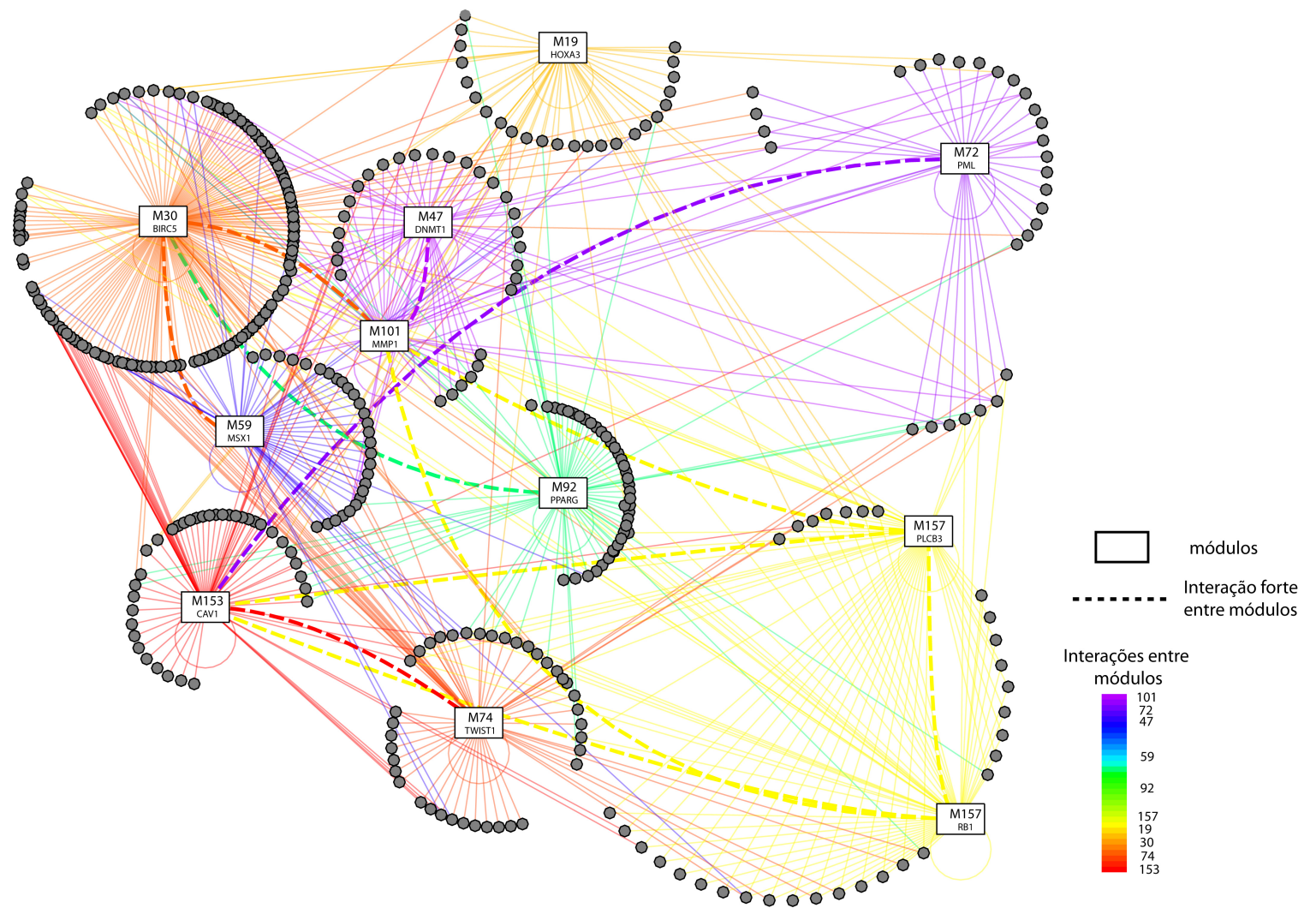

Figura 15: Rede de interação entre os genes candidatos a driver e seus módulos correspondentes. As cores estão relacionadas aos módulos e a linha tracejada indica a interação entre eles. É possível observar que o gene $D L C I 1$ apresenta interação com outros quatro candidatos a drivers: $B I R C 5, R B 1, P L C B 3 \mathrm{e}$ DNMT1.

\subsubsection{Propriedades Topológicas de Redes}

Após a representação em rede das interações entre genes co-expressos e seus possíveis reguladores foram observadas algumas propriedades topológicas, identificando os genes $R B 1, C A V 1$, $P M L$ e PPARG com os maiores graus de conectividade $(k=150, k=88, k=70, k=50$, respectivamente), a partir de uma lista com 485 genes e 2.816 interações, considerando $d=1$. Os genes RB1 e CAV1 também apresentaram alta centralidade de intermediação (betweenness centrality), indicando uma tendência em ocupar posições relevantes na comunicação entre módulos de genes. Ao mesmo tempo, apresentam um coeficiente de clusterização baixo, sugerindo baixa conectividade entre seus vizinhos próximos. Detalhadamente, o maior valor de centrali- 
dade de intermediação foi identificado para o gene CAV1 (13.874), seguido pelos genes $P M L$ (7.834), PPARG (3.387) e RUNX3 (2.183). O maior coeficiente de clusterização foi observado para o gene TWIST1 (0.25), sendo que os genes DLC1 e SOX17 apresentaram valor igual à zero. Dados apresentados na Tabela 12

Tabela 12: Identificação das propriedades topológicas de rede para cada gene identificado como candidato a driver. Os termos centralidade de grau e centralidade de intermediação correspondem aos termos em inglês degree centrality e betweenness centrality. O gene NRN1 não apresentou interação nos bancos de dados utilizados

\begin{tabular}{cccc}
\hline Gene & $\begin{array}{c}\text { Centralidade de Grau } \\
\text { Degree centrality) }\end{array}$ & $\begin{array}{c}\text { Centralidade de Intermediação } \\
\text { (Betweenness centrality) }\end{array}$ & $\begin{array}{c}\text { Coeficiente de Clusterização } \\
\left(C_{c l u}\right)\end{array}$ \\
\hline RB1 & 150 & 25270.38 & 0.03606 \\
CAV1 & 88 & 13874.16 & 0.05042 \\
PML & 70 & 7834.925 & 0.0824 \\
PPARG & 50 & 3387.368 & 0.04082 \\
DNMT1 & 22 & 1725.634 & 0.16017 \\
RUNX3 & 20 & 2183.413 & 0.08947 \\
BIRC5 & 17 & 699.8521 & 0.15441 \\
NRAS & 17 & 1998.683 & 0.02941 \\
MSX1 & 17 & 1180.011 & 0.11029 \\
DTX2 & 15 & 1693.395 & 0.06667 \\
TNFSF10 & 14 & 1930.764 & 0.14286 \\
PLCB3 & 11 & 1144.59 & 0.03636 \\
FLI1 & 11 & 179.3294 & 0.03636 \\
TWIST1 & 9 & 574.1933 & 0.25 \\
DLC1 & 2 & 5.2998 & 0 \\
SOX17 & 1 & 0 & 0 \\
\hline
\end{tabular}

Os valores para conectividade, coeficiente de clusterização e centralidade de intermediação dos 17 genes candidatos foram apresentados em forma de gráfico, conforme apresentado na Figura 16. Em uma rede indireta, o grau de conectividade de um gene $n$ é o número de conexões ligadas a $n$. A distribuição do grau de conectividade fornece o número de genes com grau $k$ para $k=(0,1, \ldots$,$) . É possível observar em (\mathbf{A})$ que a maior parte dos genes apresenta menos de 40 interações e estão agrupados em um intervalo do coeficiente de clusterização entre 0,05 e 0,55. Nesse tipo de representação, o gene com maior conectividade (RB1) apresentou baixo coeficiente de clusterização. Em $(\mathbf{B})$ o gráfico com os valores normalizados de centralidade de intermediação e conectividade do conjunto de genes avaliados, indica que genes com menos de 30 interações apresentam um valor inferior a 0,025 (4.000) para a medida de centralidade de intermediação. 


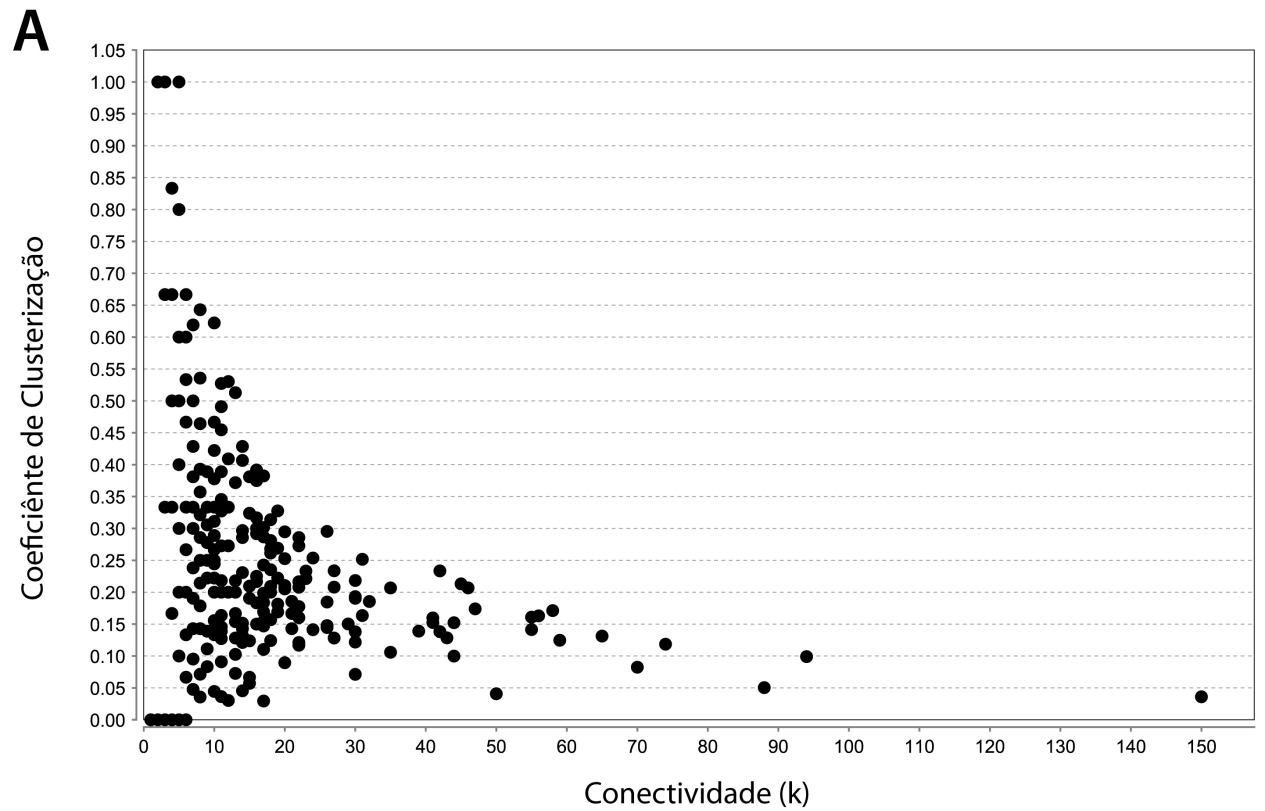

B

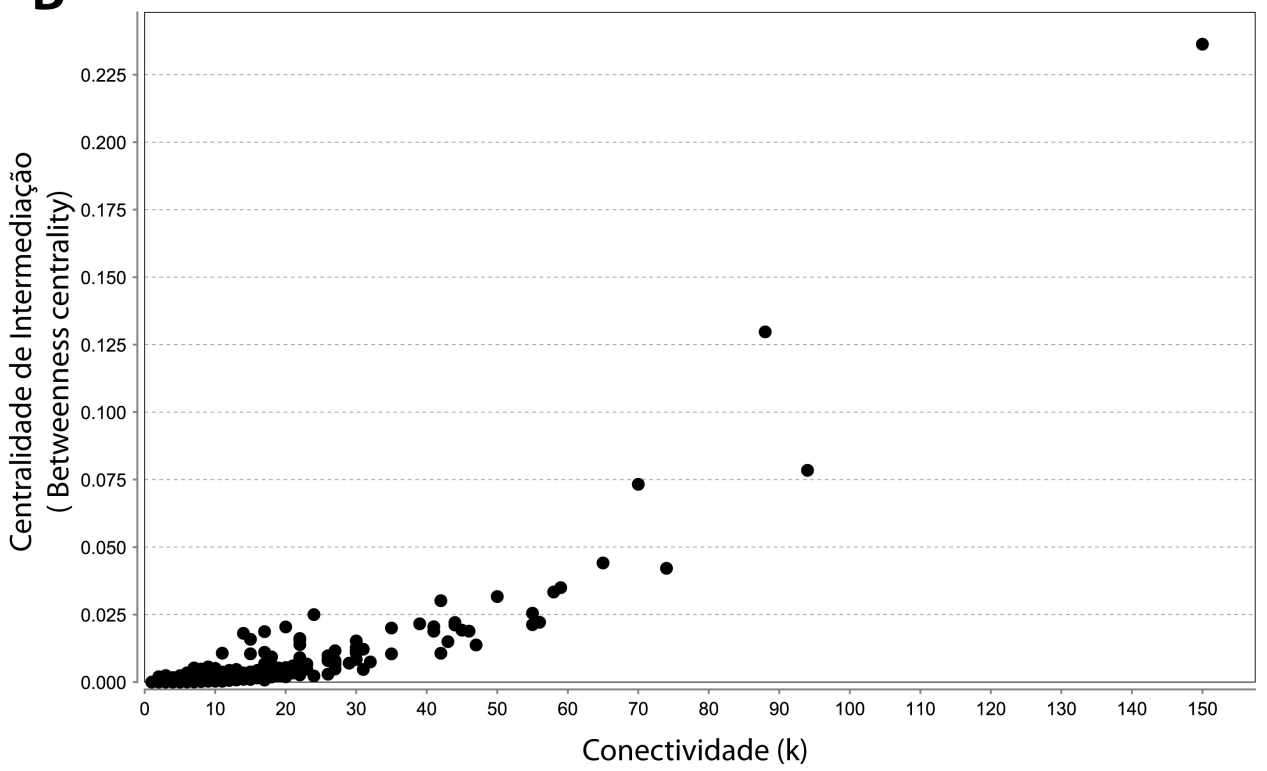

Figura 16: Representação das propriedades topológicas de rede, de acordo com os resultados obtidos nas etapas anteriores. Em (A) foi comparado o grau de conectividade (k) e o coeficiente de clusterização das interações obtidas a partir dos 73 genes candidatos. Em (B), com o mesmo conjunto de genes, foi comparada a conectividade com a centralidade de intermediação. É possível observar que genes que interagem com menos de 30 vizinhos apresentam valores de intermediação abaixo de $4.000(0,025)$ e coeficiente de clusterização entre 0,05 e 0,55 .

\subsubsection{Meta-Análise}

Na avaliação dos níveis de transcritos codificadores dos 17 candidatos a drivers em um conjunto com 1.066 amostras disponíveis no banco de dados público, TCGA, foi observado que os genes CAV1, FLI1, NRN1, MSX1, PML, DLC1, SOX17 e PPARG apresentavam níveis de expressão semelhantes (todos com expressão diminuída) entre amostras de carcinoma de pênis e os três conjuntos amostrais utilizados. Os genes DNMT1, TWIST1 e TNFSF10 (expressão aumentada em $\mathrm{CaPe}$ ) apresentaram concordância com pelo menos dois conjuntos amostrais. Porém, é possível observar que os genes $R B 1, R U N X 3$ e DTX2 apresentaram resultados contrários entre 
os valores obtidos no estudo com o carcinoma de pênis (todos os genes com expressão aumentada) e os estudos de carcinoma cervical, pulmão e cabeça e pescoço (todos os genes com expressão diminuída). Os dados foram apresentados na Tabela 13.

Tabela 13: Meta-análise utilizando 1.066 amostras obtidas no banco de dados TCGA para avaliação da expressão dos 17 genes candidatos a driver obtidos no estudo envolvendo a comparação entre amostras tumorais e normais para carcinoma de pênis. Entre parênteses foi apresentado o número de amostras para cada estudo. $[\mathrm{EA}]=$ expressão aumentada e $[\mathrm{ED}]=$ expressão diminuída. Em negrito os genes que apresentaram concordância dos valores de expressão entre todos os estudos

\begin{tabular}{|c|c|c|c|c|}
\hline \multirow[b]{2}{*}{ Gene } & \multirow[b]{2}{*}{$\begin{array}{c}\text { Carcinoma de } \\
\text { pênis }(31)\end{array}$} & \multicolumn{3}{|c|}{ TCGA } \\
\hline & & $\begin{array}{c}\text { Cervical } \\
159\end{array}$ & $\begin{array}{l}\text { Pulmão } \\
\text { (482) }\end{array}$ & $\begin{array}{c}\text { Cabeça e pescoço } \\
(425)\end{array}$ \\
\hline$B I R C 5$ & $\mathrm{EA}$ & -0.22 & 0.23 & \\
\hline$C A V 1$ & ED & -0.28 & -0.17 & -0.35 \\
\hline$D L C 1$ & ED & -0.31 & -0.26 & -0.33 \\
\hline$D N M T 1$ & EA & 0.01 & -0.10 & -0.16 \\
\hline DTX2 & EA & -0.34 & -0.19 & -0.24 \\
\hline$F L I 1$ & ED & -0.24 & -0.13 & -0.33 \\
\hline$M S X 1$ & ED & -0.32 & -0.35 & -0.24 \\
\hline$N R A S$ & EA & 0.05 & & -0.33 \\
\hline$N R N 1$ & ED & -0.27 & -0.09 & -0.37 \\
\hline PLCB3 & EA & -0.24 & -0.07 & \\
\hline$P M L$ & ED & -0.22 & -0.17 & -0.28 \\
\hline$P P A R G$ & ED & -0.38 & -0.41 & -0.46 \\
\hline$R B 1$ & $\mathrm{EA}$ & -0.39 & -0.38 & -0.43 \\
\hline RUNX3 & EA & -0.13 & -0.16 & -0.20 \\
\hline$S O X 17$ & ED & -0.25 & -0.28 & -0.35 \\
\hline TNFSF 10 & EA & 0.53 & 0.77 & -0.12 \\
\hline TWIST1 & ED & -0.35 & 0.17 & -0.18 \\
\hline
\end{tabular}

\subsection{Estudo das Alterações Moleculares em CaPe Segundo a Infecção pelo HPV}

\subsubsection{Primeira Etapa - Pré-Seleção dos Genes}

Semelhante ao estudo anterior, a primeira etapa de seleção de genes obtidos da comparação entre amostras positivas e negativas para infecção pelo vírus identificou 35 genes, sendo quatro supressores tumorais (KLK10, PRX, NOTCH1 e MXD1) e um oncogene (CTTN) (Tabela 14). A maior quantidade de genes alterados estava mapeada nos cromossomos 1 e 4 (4 genes cada), seguido pelo cromossomo 19 (3 genes). Foram observados ganhos genômicos envolvendo os genes $R F C 4$, $P C N A$ e $K L K 10$ e uma deleção para o gene $S O X 14$. Com relação às alterações de metilação do DNA foram identificados 21 genes com hipermetilação e 9 genes hipometilados. Todos os genes selecionados foram diferencialmente expressos na comparação entre amostras HPV + e HPV-, sendo 21 genes com expressão diminuída e 13 genes com expressão aumentada. Se a presença de expressão aumentada não foi notada para os miRNAs, foram observados seis genes alvos de miRNAs com expressão diminuída. Dentre os genes selecionados, quatro apresentam função de supressor tumoral (KLK10, MXD1, NOTCH1 e PRX) e um oncogene (CTTN). 
Tabela 14: Genes selecionados na primeira etapa de integração dos dados obtidos no estudo envolvendo amostras positivas e negativas para infecção pelo HPV.

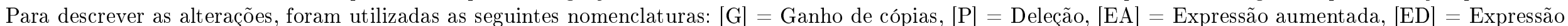

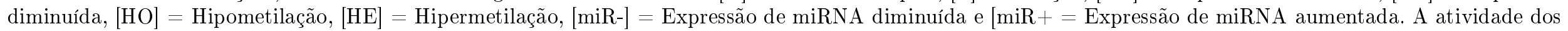
genes foi descrita como: $[\mathrm{TS}]=$ Supressor tumoral, $[\mathrm{EC}]=$ Estabilidade celular, $[\mathrm{ON}]=$ Oncogene e $[\mathrm{PQ}]=$ Proteína quinase

\begin{tabular}{|c|c|c|c|c|c|}
\hline Gene & Nome & Região & Alteração & miRNA & Função \\
\hline SYTL1 & Sinaptotagmina-like 1 & $1 \mathrm{p} 36.11$ & $\mathrm{HE} / \mathrm{ED}$ & & \\
\hline$W D R 8$ & Repetição WD, antisense para TP73 & $1 \mathrm{p} 36.3$ & $\mathrm{HE} / \mathrm{ED}$ & & \\
\hline$B 3 G A L T 6$ & UDP-Gal:betagal beta 1,3-galatosiltransferase polipeptídeo 6 & $1 \mathrm{p} 36.33$ & $\mathrm{HE} / \mathrm{ED}$ & & \\
\hline$N A V 1$ & Navegador neuronal 1 & $1 \mathrm{q} 32.3$ & $\mathrm{HE} / \mathrm{ED}$ & & \\
\hline$M X D 1$ & Proteína 1 de dimerização MAX & 2p13-p12 & $\mathrm{EA} / \mathrm{miR}-$ & $h s a-m i R-520 b$ & TS \\
\hline$I A H 1$ & Isoamil acetato-hidrolise esterase 1 homologo (S. cerevisiae) & $2 \mathrm{p} 25.1$ & $\mathrm{HE} / \mathrm{ED}$ & & \\
\hline SOX14 & SRY (proteína determinante do sexo) & $3 q 22-q 23$ & $\mathrm{P} / \mathrm{HE} / \mathrm{ED}$ & & \\
\hline$R F C 4$ & Fator de replicação C (ativador 1) 4, $37 \mathrm{kda}$ & $3 q 27$ & $\mathrm{G} / \mathrm{HO} / \mathrm{EA}$ & & $\mathrm{EC}$ \\
\hline$D A B 2$ & Dab, fosfoproteína responsiva ao mitógeno, homologo 2 (Drosophila) & $5 \mathrm{p} 13$ & $\mathrm{HO} / \mathrm{EA}$ & & $\begin{array}{l}\text { Via TGFBR e } \\
\text { Wnt }\end{array}$ \\
\hline$D U S P 1$ & Fosfatase 1 de dupla especificidade & $5 q 34$ & $\mathrm{HO} / \mathrm{EA}$ & & Via EGFR1 \\
\hline $\mathrm{FOXP}_{4}$ & Forkhead box P4 & $6 \mathrm{p} 21.1$ & $\mathrm{EA} / \mathrm{miR}-$ & $h s a-m i R-328$ & \\
\hline$Z B T B 22$ & Zinc finger e domínio BTB & $6 \mathrm{p} 21.3$ & $\mathrm{HE} / \mathrm{ED}$ & & \\
\hline GFOD1 & Glucose-frutose domínio oxidoredutase & 6pter-p22.1 & $\mathrm{EA} / \mathrm{miR}-$ & hsa-miR-328, hsa-miR-517b & \\
\hline L3MBTL3 & L(3)mbt-like 3 (Drosófila) & $6 q 23$ & $\mathrm{HE} / \mathrm{ED}$ & & \\
\hline TRIM14 & Motivo tripartido 14 & $9 \mathrm{q} 31.1$ & $\mathrm{HE} / \mathrm{ED}$ & & \\
\hline NOTCH1 & Notch 1 & $9 \mathrm{q} 34.3$ & $\mathrm{HO} / \mathrm{EA}$ & & TS \\
\hline$C C N J$ & Ciclina $\mathrm{J}$ & $10 q 23.33$ & $\mathrm{EA} / \mathrm{miR}-$ & $h s a-m i R-520 b$ & \\
\hline C10orf46 & Domínio culina 1 associado ao CDK2 & $10 q 26.11$ & $\mathrm{HO} / \mathrm{EA}-$ & & \\
\hline$L D H A$ & Lactato desidrogenase A & $11 \mathrm{p} 15.4$ & $\mathrm{HE} / \mathrm{ED}$ & & \\
\hline$C T T N$ & Cortactina & $11 q 13$ & $\mathrm{HE} / \mathrm{ED}$ & & $\mathrm{ON}$ \\
\hline CPSF6 & Clivagem e fator específico 6 de poliadenilação & $12 \mathrm{q} 14.3$ & $\mathrm{HE} / \mathrm{ED}$ & & \\
\hline C14orf4 & Fator 2 de regulação de interferon & $14 q 24.3$ & $\mathrm{HE} / \mathrm{ED}$ & & \\
\hline$M P D U 1$ & Manose-P-Dolicol & 17p13.1-p12 & $\mathrm{HE} / \mathrm{ED}$ & & \\
\hline$C 1 Q B P$ & Componente de complemento 1 , subcomponente q de ligação à proteína & $17 \mathrm{p} 13.3$ & $\mathrm{HE} / \mathrm{ED}$ & & \\
\hline$H S D 17 B 1$ & Hidroxisteróide (17-beta) desidrogenase 1 & $17 q 11-q 21$ & $\mathrm{HE} / \mathrm{ED}$ & & \\
\hline$S M A R C D 2$ & SWI/SNF dependente, regulador da cromatina actina dependente & $17 q 23-q 24$ & $\mathrm{HE} / \mathrm{ED}$ & & \\
\hline$P R X$ & Periaxina & 19q13.13-q13.2 & $\mathrm{HE} / \mathrm{ED}$ & & TS \\
\hline
\end{tabular}


GEMIN 7

KLK10

$P C N A$

TAF4

BRWD1

COL18A1

DERL3

C1QTNF6
Gem (organela nuclear) proteína 7 associada

Calicreína peptidase 10

Antígeno nuclear de Proliferação celular

TAF4 RNA polimerase II, TATA box associado à TBP

Bromodomínio e domínio de repetição WD

Colágeno, tipo XVIII, alfa 1

Derlina 3

C1q e fator de necrose tumoral
$19 \mathrm{q} 13.32$

19q13.3-q13.4

20pter-p12

$20 \mathrm{q} 13.33$

$21 \mathrm{q} 22.2$

$21 \mathrm{q} 22.3$

$22 \mathrm{q} 11.23$

22q13.1
$\mathrm{HO} / \mathrm{EA}$

$\mathrm{G} / \mathrm{EA} / \mathrm{HO}$

TS

$\mathrm{EA} / \mathrm{HO} / \mathrm{miR}-$

$\mathrm{HO} / \mathrm{EA}$

$\mathrm{EA} / \mathrm{miR}$ -

$\mathrm{HE} / \mathrm{ED}$

HE/ED

$\mathrm{HE} / \mathrm{ED}$ 
Os candidatos também foram relacionados a funções importantes relacionadas com a infecção pelo vírus do HPV, como por exemplo, crescimento e proliferação celular ( $L D H A, P C N A$, TRRAP), transporte no sistema imune (COL18A1, DUSP1, INPP5D, L3MBTL3, NOTCH1), ciclo celular (NOTCH1) e desenvolvimento celular (LDHA, PCNA, TRRAP, C1QBP, COL18A1, DAB2, DUSP1, INPP5D e NOTCH1). Os genes CTTN, DUSP1, KLK10, KLK', LDHA, NOTCH1 e $P C N A$ também foram enriquecidos para doenças como o câncer (Tabela 15).

Tabela 15: Genes enriquecidos para diversas funções e doenças na comparação entre amostras e carcinoma de pênis positivas e negativas para infecção pelo HPV. Foi utilizado o critério de significância de $p<5 \times 10^{-2}$.

\begin{tabular}{|c|c|c|}
\hline Categoria & P-Valor & Genes \\
\hline Desenvolvimento celular & $1 x 10^{-3}$ & $\begin{array}{llrr}\text { LDHA, } & \text { PCNA, } & \text { TRRAP, } & \text { C1QBP, } \\
\text { COL18A1, DAB2, } & \text { DUSP1, } & \text { INPP5D, } \\
\text { NOTCH1 } & & & \end{array}$ \\
\hline Crescimento e proliferação & $1 \times 10^{-3}$ & LDHA, PCNA, TRRAP \\
\hline Desenvolvimento de pele e cabelo & $1,9 \times 10^{-3}$ & NOTCH1, TAF4 \\
\hline Movimento celular & $1,9 x 10^{-3}$ & $C 1 Q B P, C T T N$, NOTCH1 \\
\hline Câncer & $2,3 \times 10^{-3}$ & $\begin{array}{l}\text { CTTN, DUSP1, KLK10, KLK } 7, \text { LDHA, } \\
\text { NOTCH1, PCNA }\end{array}$ \\
\hline Metabolismo de carboidrato & $2,8 \times 10^{-3}$ & $C 1 Q B P$ \\
\hline Ciclo celular & $2,8 x 10^{-3}$ & NOTCH1 \\
\hline Morte celular & $2,8 x 10^{-3}$ & COL18A1 \\
\hline Morfologia tumoral & $2,8 x 10^{-3}$ & COL18A1 \\
\hline Desenvolvimento embrionário & $5 x 10^{-3}$ & CSNK1D, FOXP4, NOTCH1 \\
\hline Desenvolvimento tecidual & $9 \times 10^{-3}$ & $\begin{array}{l}\text { COL18A1, DUSP1, INPP5D, L3MBTL3, } \\
\text { NOTCH1 }\end{array}$ \\
\hline Desenvolvimento do sistema hematológico & $9 x 10^{-3}$ & $\begin{array}{l}\text { COL18A1, DUSP1, INPP5D, L3MBTL3, } \\
\text { NOTCH1 }\end{array}$ \\
\hline Sistema imune - tráfico celular & $9 x 10^{-3}$ & $\begin{array}{l}\text { COL18A1, DUSP1, INPP5D, L3MBTL3, } \\
\text { NOTCH1 }\end{array}$ \\
\hline Resposta inflamatória & $9 \times 10^{-3}$ & $\begin{array}{l}\text { COL18A1, DUSP1, INPP5D, L3MBTL3, } \\
\text { NOTCH1 }\end{array}$ \\
\hline
\end{tabular}

Os mesmos genes também foram associados com vias suscetíveis à toxicidade, identificando candidatos a biomarcadores tecido-específicos. Como apresentado na Tabela 16, alguns grupos de genes foram relacionados a vias importantes como fator indutor de hipóxia (CSNK1D, LDHA), sinalização do p53 ( $P C N A, C S N K 1 D)$ e mecanismo de regulação gênica pela proliferação de peroxissomo via PPARI (DUSP1). O gene DUSP1, mapeado na região 5q34, apresentou a maior frequência de associação com vias, sendo identificado em seis delas, seguido pelos genes $L D H A$ (4 vias), PNKD (2 vias) e CSNK1D (2 vias). 
Tabela 16: Vias biológicas susceptíveis a efeitos de componentes tóxicos. Para avaliar se os genes identificados no estudo sobre a influência do HPV no desenvolvimento de CaPe estavam presentes em vias susceptíveis a efeitos toxicológicos foi feito um enriquecimento utilizando o banco de dados CTD ( Comparative Toxicogenomics Database, disponível em http://ctdbase.org/). Para escolha das vias significativas foi considerado $p<10^{-3}$.

\begin{tabular}{lccl}
\hline \multicolumn{2}{l}{ Vias biológicas } & P-Valor & Genes \\
\hline $\begin{array}{l}\text { Painel de Insuficiência Renal Aguda } \\
\text { (Rato) }\end{array}$ & $1,95 \times 10^{-7}$ & COL18A1, LDHA \\
Ativação RAR & $1,89 \times 10^{-7}$ & TAF4, DUSP1, SMARCD2 \\
Fator indutor de hipóxia & $1,78 \times 10^{-7}$ & CSNK1D, LDHA \\
Sinalização do p53 & $1,52 \times 10^{-7}$ & PCNA, CSNK1D \\
Stress oxidativo & $8,2 \times 10^{-7}$ & DUSP1 \\
Aumento da esteatose hepática & $7,6 \times 10^{-7}$ & DUSP1 \\
Ativação VDR/RXR & $6,9 x 10^{-7}$ & MXD1 \\
Mecanismo de regulação gênica pela proli- & $6,2 \times 10^{-7}$ & DUSP1 \\
feração de peroxissomo via PPARI & & \\
Hipertrofia cardíaca & $5,9 x 10^{-7}$ & DUSP1, PNKD \\
Diminuição do potencial transmembrana & $5,4 x 10^{-7}$ & LDHA \\
de mitocôndrias & & \\
Necrose renal/morte celular & $4,2 x 10^{-7}$ & DUSP1, LDHA \\
Fibrose cardíaca & $4,1 \times 10^{-7}$ & PNKD \\
\hline
\end{tabular}

Para a identificação de possíveis reguladores dos 35 genes identificados foi utilizado o pipeline proposto em "Identificação de possíveis reguladores - Materiais e Métodos", página 40. Foram identificados genes candidatos a reguladores como os fatores de transcrição $K L F 5, S P Z 1, V H L$, CUX1 e NEO1. Também foram identificados os miRNAs hsa-let-7a-5p, hsa-miR-4687-3p, hsa$m i R-124, h s a-m i R-4667-3 p$, hsa-miR-140-3p, hsa-miR-101 e hsa-miR-326, descritos em literatura como reguladores de genes importantes como DUSP1, NOTCH1, KLK10, MXD1 e FZD5. Dentre os 13 genes identificados, oito estão presentes na matriz de genes diferencialmente expressos obtidos no estudo do carcinoma de pênis (HPV + vs HPV-). Dentre os genes avaliados, foram identificados mais frequentemente envolvidos com os candidatos a reguladores o PCNA (8 vezes), NOTCH (6 vezes) e DUSP (6 vezes). Os dados foram apresentados na Tabela 17. 
Tabela 17: Possíveis candidatos a reguladores. A partir de informações disponíveis na literatura foram identificados genes significativamente descritos como possíveis reguladores dos genes selecionados na primeira etapa da metodologia de integração de dados (HPV+ vs HPV-). O gene $K L F 5$, mapeado na região $13 \mathrm{q} 22.1$, apresentou o menor p-valor $\left(3,06 x 10^{-4}\right)$ para a possível regulação dos genes DUSP1, NOTCH1 e PCNA. $[\mathrm{EA}]=$ expressão aumentada, $[\mathrm{ED}]=$ expressão diminuída.

\begin{tabular}{|c|c|c|c|c|}
\hline Reguladores & Tipo molecular & P-Valor & CaPe (expressão) & Genes \\
\hline KLF5 & Regulação da transcrição & $3,06 \times 10^{-4}$ & EA & DUSP1, NOTCH1, PCNA \\
\hline hsa-let-7a-5p & miRNA maduro & $1,76 \times 10^{-3}$ & & $\begin{array}{lrr}\text { BRWD1, } & C C N J, & C S N K 1 D, \\
\text { DUSP1, } & \text { GEMIN7, } & \text { GFOD1, } \\
\text { KLK10, } & \text { MXD1, } & \text { PNKD }, \\
\text { RRP1B } & & \end{array}$ \\
\hline CHUK & Quinase & $1,84 x 10^{-3}$ & EA & $\begin{array}{l}\text { COL18A1, MXD1, NOTCH1, } \\
\text { PCNA }\end{array}$ \\
\hline POFUT1 & Enzima & $2,85 x 10^{-3}$ & & NOTCH1 \\
\hline$S P Z 1$ & Regulação da transcrição & $2,85 \times 10^{-3}$ & & $P C N A$ \\
\hline CLIP1 & Outro & $2,85 \times 10^{-3}$ & ED & $P C N A$ \\
\hline$h s a-m i R-4687-3 p$ & miRNA maduro & $3,26 x 10^{-3}$ & & CACUL1, FASTKD2, TAF4 \\
\hline$V E G F A$ & Fator de crescimento & $3,29 \times 10^{-3}$ & $\mathrm{ED}$ & $\begin{array}{l}\text { HSD 17B1, INPP5D, } \\
\text { NOTCH1, PCNA }\end{array}$ \\
\hline hsa-miR-124 & miRNA maduro & $3,37 x 10^{-3}$ & & 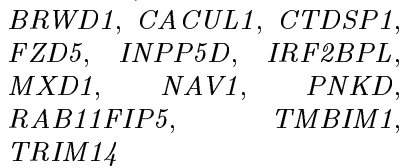 \\
\hline$K D R$ & Quinase & $3,53 \times 10^{-3}$ & ED & INPP5D, NOTCH1 \\
\hline$h s a-m i R-4667-3 p$ & miRNA maduro & $3,92 \times 10^{-3}$ & & $\begin{array}{l}\text { BRWD1, C9orf3, NAV1, } \\
\text { PNKD, ZBTB22 }\end{array}$ \\
\hline$h s a-m i R-140-3 p$ & miRNA maduro & $4,23 x 10^{-3}$ & & CACUL1, CCNJ, TMBIM1 \\
\hline$F S H$ & Complexo & $4,25 \times 10^{-3}$ & & $\begin{array}{l}\text { COL18A1, DAB2, DUSP1, } \\
\text { HSD17B1, PCNA }\end{array}$ \\
\hline$V H L$ & Regulação da transcrição & $4,44 x 10^{-3}$ & ED & $D A B 2, H S D 17 B 1, P C N A$ \\
\hline$C U X 1$ & Regulação da transcrição & $5,54 x 10^{-3}$ & & $D A B 2, K L K 8$ \\
\hline GPR 68 & Receptor da proteína $\mathrm{G}$ & $5,70 \times 10^{-3}$ & EA & DUSP1 \\
\hline$h s a-m i R-101$ & miRNA & $5,70 \times 10^{-3}$ & & DUSP1 \\
\hline$h s a-m i R-326$ & miRNA & $5,70 \times 10^{-3}$ & & NOTCH1 \\
\hline$C Y P 2 C 9$ & Enzima & $5,70 \times 10^{-3}$ & & DUSP1 \\
\hline NEO1 & Regulação da transcrição & $5,70 \times 10^{-3}$ & ED & $P C N A$ \\
\hline
\end{tabular}

\subsubsection{Seleção de Módulos}

Após 100 simulações, o programa de atribuição dos genes identificados na primeira etapa como possíveis reguladores de conjuntos de genes co-expressos identificou 25 módulos que passaram por todos os critérios de seleção, conforme explicado em "Redes em módulos - Materiais e Métodos". Na Figura 17 é possível observar que 13 módulos foram identificados com p-valor igual a zero e outros 12 foram selecionados com $\mathrm{p}<0,0065$. Os módulos que não passaram por esse critério não foram selecionados para as etapas seguintes. 


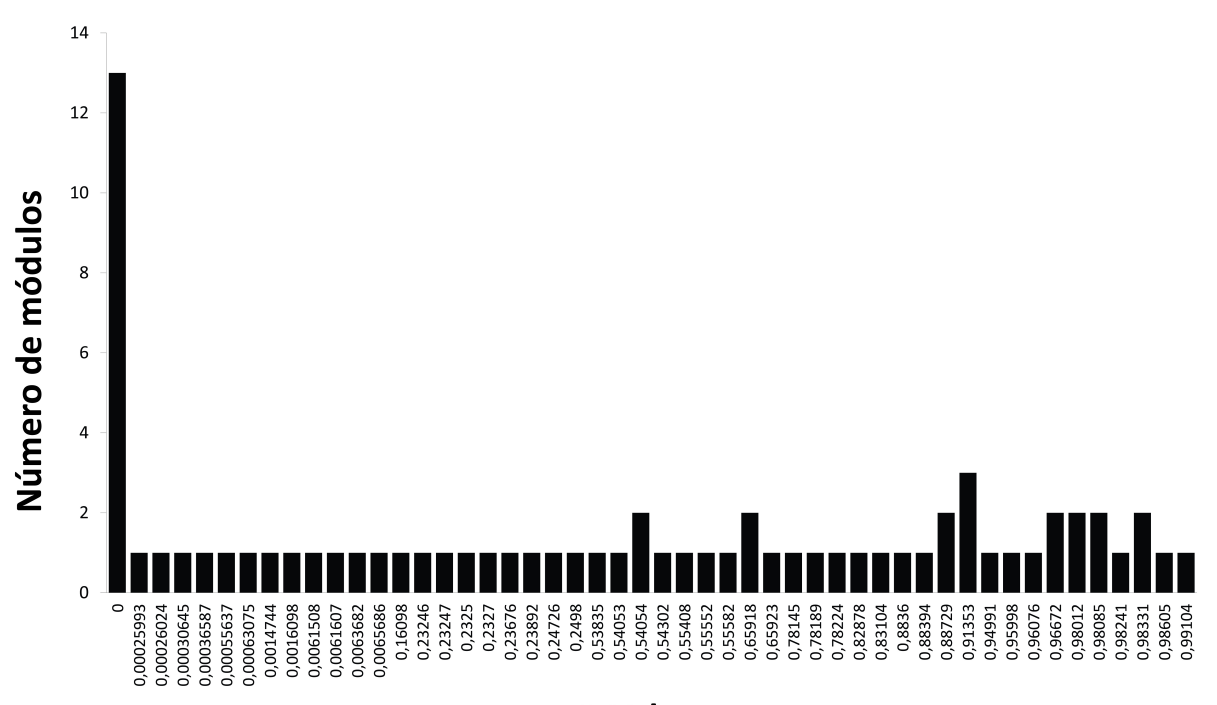

P-Valor

Figura 17: Representação dos módulos selecionados no estudo sobre a influência do HPV no desenvolvimento do carcinoma de pênis. É possível observar que a maior concentração de módulos foi dentro do limite de significância estabelecido $\left(p<5 \times 10^{-2}\right)$.

\subsubsection{Atribuição de Módulos}

A partir dos 35 genes atribuídos como possíveis reguladores dos 25 módulos foram identificados quatro genes candidatos a drivers, selecionados para análises posteriores. Dos quatro genes, dois ( $R F C 4$ e $S O X 14$ ) estão mapeados no cromossomo 3, e os genes KLK10 e PCNA estão mapeados nos cromossomos 19 e 20, respectivamente. Foram identificadas quatro alterações genômicas, sendo três ganhos de cópias para os genes KLK10, PCNA e RFC4 e uma deleção para o gene SOX14. Apenas um miRNA diferencialmente expresso (hsa-miR-154) foi identificado como regulador do gene $P C N A$. Com relação a expressão dos transcritos codificadores, foram identificados três genes com expressão aumentada (KLK10, PCNA e RFC4) e um com expressão diminuída do $S O X 14$ em pacientes $\mathrm{HPV}+$. As interações físicas entre genes co-expressos e os quatro reguladores foram identificadas com média de $20 \%$ por módulo. Nesses módulos foi identificada a presença média de aproximadamente quatro genes passengers por módulo e 18 genes por módulo. Os dados foram apresentados na Tabela 18.

Os módulos associados com os genes KLK10, SOX14, PCNA e RFC4 foram apresentados na Tabela 19. O gene supressor tumoral KLK10 foi identificado apenas como regulador do módulo 2 (enriquecido para crescimento e manutenção celular, GO:0008151, $p=3 \times 10^{-2}$ ), formado por 18 genes, sendo quatro deles passengers. A interação entre o candidato a driver e os genes coexpressos presentes no módulo foi de $22,2 \%$. O produto codificado por esse gene pertence ao subgrupo das serinas proteases sendo identificado no estudo com ganho de cópias do DNA e expressão aumentada do transcrito. O gene $R F C$ 4, essencial em várias etapas do ciclo celular, foi associado aos módulos 0,6 e 8, porém foi atribuído estatisticamente apenas como regulador do módulo 8, devido aos critérios utilizados (módulo enriquecido para replicação do DNA e presença de $12 \%$ de interação proteína-proteína). O antígeno nuclear de proliferação celular (PCNA) foi associado com atividade proliferativa, sendo que a síntese de proteína ocorre durante a interfase e desaparece no final da mitose. 
Tabela 18: Lista com os quatro candidatos a driver selecionados pela metodologia de integração de dados.

\begin{tabular}{|c|c|c|c|c|c|c|c|}
\hline Gene & Região & Alteração & Módulo & GO-ID & $\% \mathbf{P P I}$ & Genes passengers & Função \\
\hline$K L K 10$ & $19 \mathrm{q} 13.3-\mathrm{q} 13.4$ & $\mathrm{G} / \mathrm{EA} / \mathrm{HO}$ & 2 & GO:0008151 (Proliferação celular) & 22,2 & $4 / 18$ & TS \\
\hline$P C N A$ & 20pter-p12 & $\mathrm{G} / \mathrm{EA} / \mathrm{HO} / \mathrm{miR}-$ & 5 & GO:0008283 (Crescimento celular/manutenção) & 35,7 & $5 / 14$ & $\mathrm{EC}$ \\
\hline $\mathrm{RFC}_{4}$ & $3 q 27$ & $\mathrm{G} / \mathrm{HO} / \mathrm{EA}$ & 8 & GO:0006260 (Replicação do DNA) & 12,0 & $5 / 25$ & $\mathrm{EC}$ \\
\hline$S O X 14$ & $3 q 22-q 23$ & $\mathrm{P} / \mathrm{HE} / \mathrm{ED}$ & 15 & GO:0006325 (Manutenção) & 17,6 & $4 / 17$ & \\
\hline
\end{tabular}

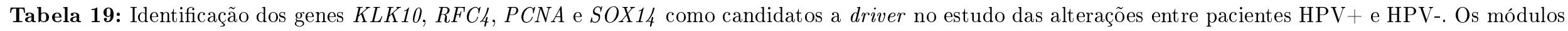

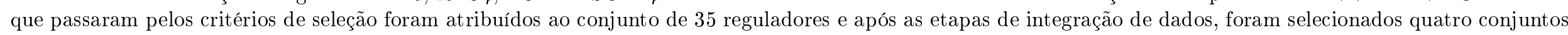
(regulador + módulo) para estudos posteriores. Em um caso específico, o gene PCNA, identificado como regulador dos módulos 5,7 e 12 , foi selecionado apenas por sua associação com o módulo cinco (enriquecido para a via de proliferação celular, formado por 14 genes, sendo cinco passengers e frequência de PPI de $35,7 \%$.

\begin{tabular}{|c|c|c|c|c|c|c|}
\hline Processo Biológico & P-Valor & Candidato a driver & GO ID & módulo & Genes passengers|módulo & $\%$ PPI \\
\hline Metabolismo & $1,4 x 10^{-2}$ & $R F C 4$ & GO:0008152 & 0 & $0 / 15$ & 0,0 \\
\hline Organogênese & $2 x 10^{-2}$ & $S O X 14$ & GO:0009887 & 1 & $1 / 18$ & 5,6 \\
\hline Proliferação celular & $3,3 x 10^{-3}$ & $P C N A$ & GO:0008283 & 5 & $5 / 14$ & 35,7 \\
\hline Crescimento celular/manutenção & $3 x 10^{-2}$ & $K L K 10$ & GO:0008151 & 2 & $4 / 18$ & 22,2 \\
\hline Ciclo celular mitótico fase $\mathrm{S}$ & $1,3 x 10^{-2}$ & $K L K 10$ & GO:0007049 & 9 & $0 / 14$ & 0,0 \\
\hline Replicação do DNA & $1,3 x 10^{-2}$ & $P C N A$ & GO:0006261 & 12 & $1 / 15$ & 6,7 \\
\hline Replicação do DNA & $2,8 x 10^{-2}$ & $P C N A$ & GO:0000067 & 7 & $2 / 21$ & 9,5 \\
\hline Nucleotídeo e metabolismo de ácido nucleico & $9,4 x 10^{-3}$ & $\mathrm{RFC}_{4}$ & GO:0006139 & 6 & $1 / 26$ & 3,8 \\
\hline Replicação do DNA & $2,4 x 10^{-2}$ & $R F C 4$ & GO:0006260 & 8 & $5 / 25$ & 12,0 \\
\hline Manutenção & $2,7 x 10^{-2}$ & $S O X 14$ & GO:0006325 & 15 & $4 / 17$ & 17,6 \\
\hline Metabolismo do DNA & $6,7 x 10^{-3}$ & $S O X 14$ & GO:0006259 & 21 & $2 / 24$ & 8,3 \\
\hline Neurogênese & $2,1 x 10^{-2}$ & $S O X 14$ & GO:0007399 & 16 & $0 / 22$ & 0,0 \\
\hline
\end{tabular}

*em negrito foram representados os módulos selecionados pelos critérios estabelecidos nas etapas de integração de dados. PPI = interação proteína-proteína, GO ID = Código de identificação da via biológica no banco de dados Gene Ontology. 
A Figura 18 apresenta o processo de atribuição do gene $P C N A$ como regulador do módulo 5. É possível observar na figura que o gene SUPT3H foi identificado como componente do processo de transição da fase G2/M durante o ciclo celular. Nesta figura também foram representadas as interações existentes entre os genes do módulo 5 e o $P C N A$, indicando a existência de interação física entre os genes co-expressos, tais como o CDK6, EEF1A1, CDK1, MSH6, CDK5 e CDK4 e o regulador. Também é possível destacar a presença dos genes passengers $C D K N 1 A, C D K N 2 A$ e MSH6 no módulo, sugerindo uma possível participação desses genes na via de proliferação celular regulada pelo $P C N A$. A rede apresentada na Figura 18 demonstra a interação física existente entre os genes co-expressos presentes no módulo 5 e o regulador (PCNA). Assim como descrito no estudo das alterações entre amostras tumorais e normais de carcinoma de pênis, os genes presentes na rede foram relacionados com artigos disponíveis na literatura, onde o cálculo TF*IDF (explicado em "Identificação de possíveis reguladores") resultou em alta pontuação para o termo (nome do gene), sugerindo que a alta conectividade encontrada está relacionada a grande quantidade de citações desse termo.

A Figura 20 apresenta as interações entre três módulos identificados nesse estudo: módulo 5 (PCNA), módulo 8 (RFC4) e módulo 2 (KLK10). É possível observar uma interação entre os módulos 5 e 8 , regulados pelos genes $P C N A$ e $R F C 4$, respectivamente. Ambos os módulos foram enriquecidos para processos envolvendo replicação e proliferação celular. Apesar da importância biológica do gene SOX14 na regulação da transcrição, não foi identificada uma relação física entre ele e os outros candidatos a drivers durante a construção da rede.

No estudo sobre a influência do HPV em câncer de pênis esse gene foi associado ao módulo 5 , enriquecido para proliferação celular (GO:0008283, $p=3,6 \times 10^{-3}$ ). Ainda, esse módulo foi formado por 14 genes (cinco passengers) e possuia 35,7\% de interação proteína-proteína associando os genes co-expressos do módulo com o regulador. O SOX14, mapeado em 3q22-q23, foi atribuído como regulador dos módulos 15,16 e 31, porém o módulo 15 foi o único que apresentou a quantidade de passengers $(3 / 17)$ e interações proteína-proteína $(17,6 \%)$ acima do limiar anteriormente definido. 

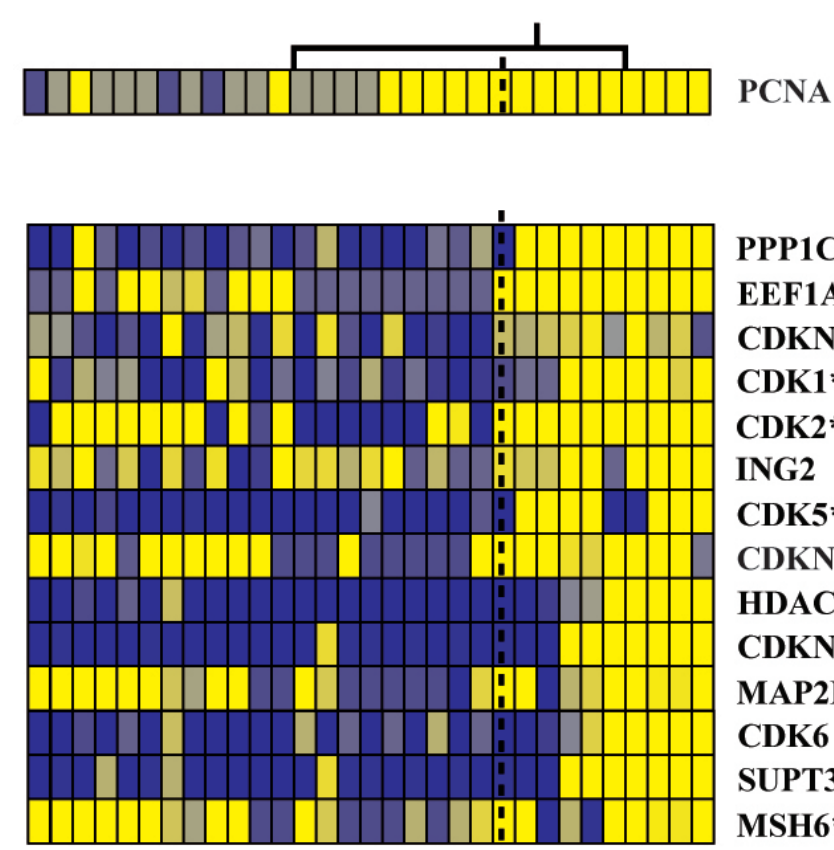

PPP1CA EEF1A1 CDKN1A CDK1*

CDK2*

ING2

CDK5*

CDKN2A*

HDAC4

CDKN1C

MAP2K3

CDK6

SUPT3H

MSH6*

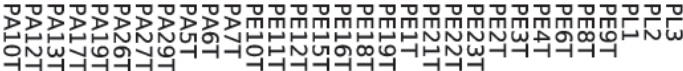

0क्ष
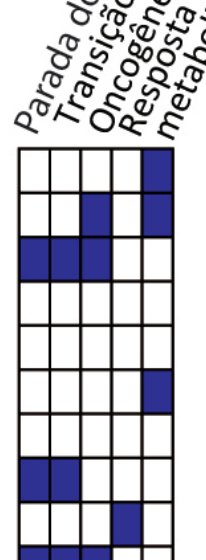

12859901

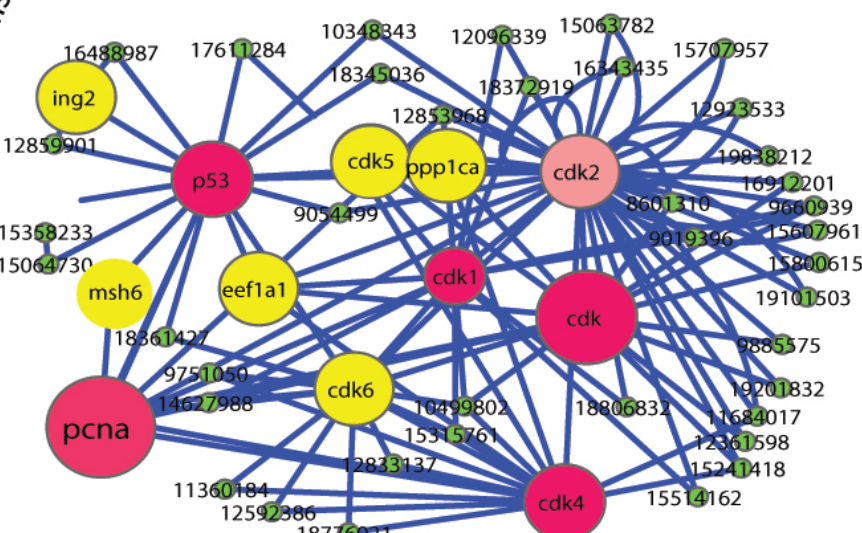

Figura 18: Atribuição do gene PCNA como regulador do módulo 5. A matriz apresenta todas as amostras estudadas em câncer de pênis dispostas em colunas e os genes em linhas. Os asteriscos indicam os genes identificados como passengers. Cada gene do módulo foi relacionado a um ou vários processos (representados pela cor azul). No caso do gene PCNA, o módulo foi enriquecido para proliferação celular, e contém cinco genes identificados como passengers. A rede apresenta a interação entre os genes de acordo com sua representatividade além das interações desses genes com estudos publicados na literatura. 


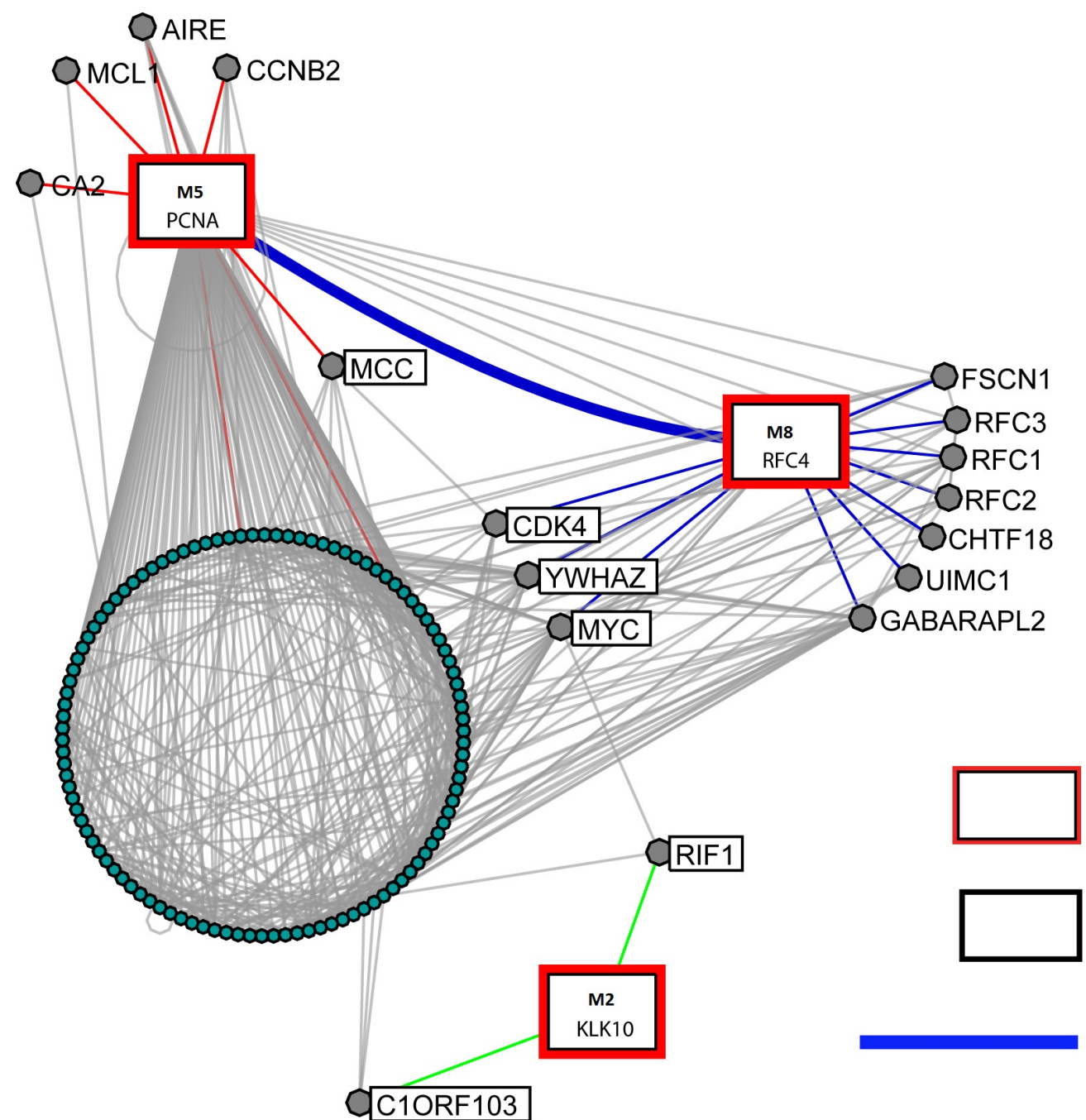

candidatos a driver

módulos

\section{Interação forte} entre módulos

Figura 19: Interação entre os módulos regulados pelos genes $P C N A, K L K 10$ e $R F C 4$. Observa-se uma interação entre os módulos 5 e 8 , ambos enriquecidos para processos envolvendo ciclo celular, regulados pelos genes PCNA e RFC4. O gene SOX14 não apresentava interações com os genes da rede. 


\subsubsection{Propriedades Topológicas de redes}

Foram obtidas as interações proteína-proteína dos quatro genes selecionados, resultando em uma lista com 126 genes e 447 interações e avaliadas algumas medidas topológicas. O gene $P C N A$ foi identificado com alta conectividade $(k=115)$, seguido pelo gene $R F C 4 \quad(k=17)$. O gene KLK10 apresentou valores baixos para conectividade $(k=2)$, centralidade de intermediação $(0,9)$ e coeficiente de clusterização $(0)$. Com relação ao gene $S O X 14$, não foram obtidas interações com os genes dos bancos de interação proteína-proteína utilizados no estudo. Além de sua alta conectividade, o gene $P C N A$ apresentou o maior valor para centralidade de intermediação (5.904), porém foi observado baixo coeficiente de clusterização, se comparado com o gene $R F C 4$ ( $C^{c l u}$ igual a 0,22 ). Ressalta-se que os genes $P C N A$ e $R F C 4$, além de alta conectividade, foram identificados com reguladores de vias biológicas envolvidas com o ciclo celular, sugerindo um possível papel de destaque no desenvolvimento do carcinoma de pênis pela via do HPV. Os dados foram apresentados na Tabela 20.

Tabela 20: Identificação de medidas topológicas de rede para cada gene identificado como candidato a driver no estudo sobre alterações obtidas da comparação entre amostras HPV + e HPV- para carcinoma de pênis. O gene SOX14 não apresentou interações nos bancos de dados pesquisados.

\begin{tabular}{cccc}
\hline Gene & $\begin{array}{c}\text { Centralidade de Grau } \\
\text { Degree centrality) }\end{array}$ & $\begin{array}{c}\text { Centralidade de Intermediação } \\
\text { (Betweenness centrality) }\end{array}$ & $\begin{array}{c}\text { Coeficiente de Clusterização } \\
\left(C_{\text {clu }}\right)\end{array}$ \\
\hline PCNA & 115 & $5.904\left(0,76^{*}\right)$ & 0.03982 \\
$R F C 4$ & 17 & $246\left(0,03^{*}\right)$ & 0.22794 \\
KLK10 & 2 & $0.9\left(0,00011^{*}\right)$ & 0 \\
\hline
\end{tabular}

A conectividade, coeficiente de clusterização e centralidade de intermediação dos quatro genes candidatos foram apresentadas em forma de gráfico, conforme apresentado na Figura ??. Em uma rede indireta, o grau de conectividade de um gene $n$ é o número de conexões ligadas a $n$. A distribuição do grau de conectividade fornece o número de genes com grau $k$ para $k=$ $0,1, \ldots, \infty$. Na figura é possível observar em (A) que a maior parte dos genes apresenta menos de 30 interações e estão agrupados em um intervalo do coeficiente de clusterização entre 0,10 e 0,70. Nesse tipo de representação, o gene com maior conectividade (PCNA) apresentou baixo coeficiente de clusterização. Em (B) o gráfico com os valores normalizados de centralidade de intermediação e conectividade do conjunto de genes avaliados, indica que genes com menos de 30 interações apresentam um valor inferior a 0,05 para a medida de centralidade de intermediação. 


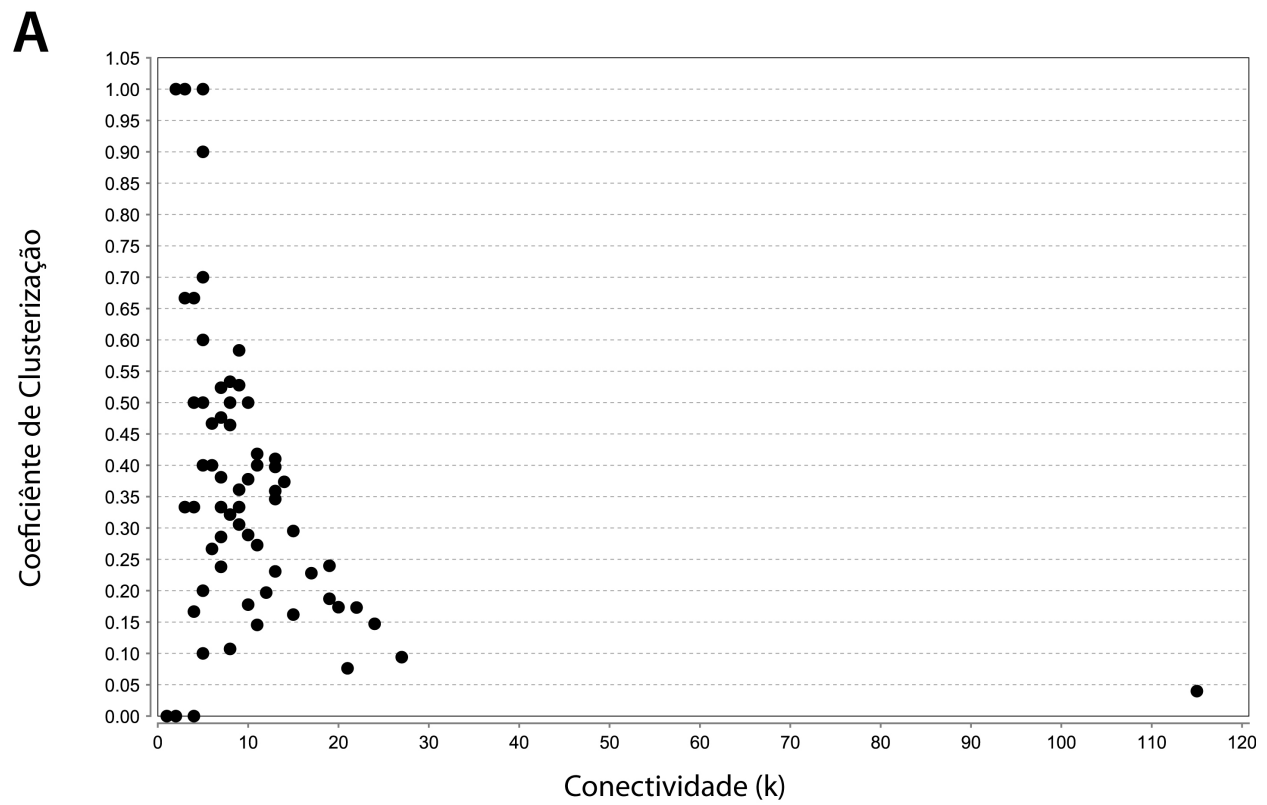

B

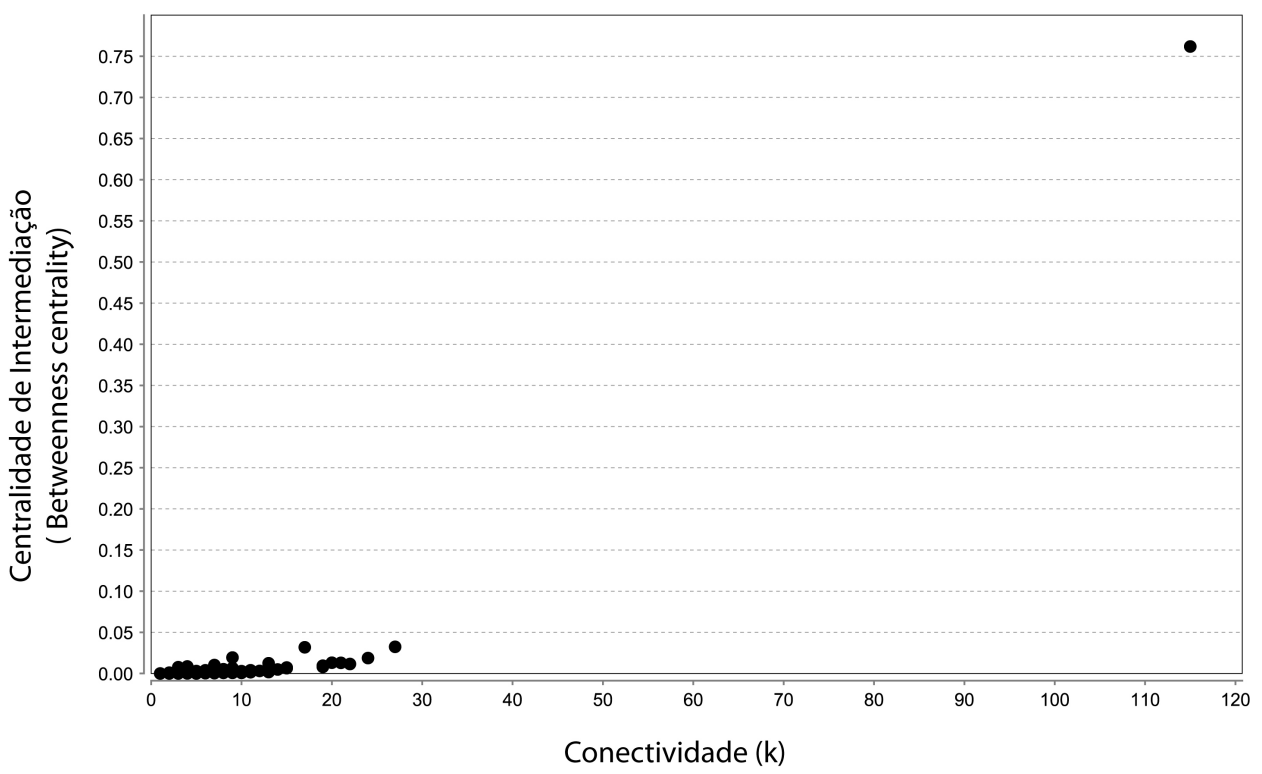

Figura 20: Representação das propriedades topológicas de rede, de acordo com os resultados obtidos nas etapas anteriores. Em (A) foi comparado o grau de conectividade (k) e o coeficiente de clusterização das interações obtidas a partir dos quatro genes candidatos. Em (B), com o mesmo conjunto de genes, foi comparada a conectividade com a centralidade de intermediação. É possível observar que genes que interagem com menos de 30 vizinhos apresentam valores de intermediação abaixo 0,05 e coeficiente de clusterização entre 0,10 e 0,70. 


\subsubsection{Meta-Análise}

Os níveis de transcritos codificadores dos quatro genes selecionados como candidatos a drivers foram avaliados em 210 amostras independentes obtidas a partir de dois bancos de dados públicos (TCGA e NCBI-GEO). Foram observados níveis semelhantes de expressão para o gene $R F C 4$ (expressão aumentada), tanto no carcinoma de pênis como nos outros cinco conjuntos de amostras utilizados. A expressão aumentada do gene PCNA também foi concordante com os estudos de carcinoma de cabeça e pescoço (disponível no TCGA) e dois estudos sobre carcinoma cervical e um sobre cabeça e pescoço (disponíveis no NCBI-GEO). Observa-se também que a expressão aumentada do gene KLK10 em CaPe é discordante dos outros conjuntos amostrais. Já a expressão diminuída do gene SOX14 em CaPe também foi observada no estudo com amostras de carcinoma cervical disponível no TCGA e com outros dois conjuntos de amostras obtidas no NCBI-GEO (carcinoma cervical e de cabeça e pescoço, disponível no estudo GSE6791). Dados disponíveis na Tabela 21.

Tabela 21: Meta-análise utilizando os bancos de dados TCGA e NCBI-GEO para avaliação da expressão dos quatro genes candidatos a driver obtidos da comparação entre amostras positivas e negativas para infecção pelo HPV. Entre parênteses foi apresentado o número de amostras para cada estudo. [EA] = expressão aumentada e $[\mathrm{ED}]=$ expressão diminuída.

\begin{tabular}{|c|c|c|c|c|c|c|}
\hline \multirow[b]{2}{*}{ Gene } & \multirow[b]{2}{*}{$\mathrm{CaPe}(31)$} & \multicolumn{2}{|l|}{ TCGA } & \multicolumn{3}{|c|}{ NCBI-GEO } \\
\hline & & Cabeça e pescoço(59) & Cervical(12) & Cervical $(28)^{1}$ & ${\text { Cabeça e pescoço }(56)^{1}}^{1}$ & Cervical $(55)^{2}$ \\
\hline KLK10 & EA & & -0.42 & -3.20 & -2.93 & -1.35 \\
\hline$P C N A$ & EA & 2.02 & & 3.86 & 1.68 & 4.01 \\
\hline $\mathrm{RFCH}_{4}$ & $\mathbf{E A}$ & 2.60 & 5.77 & 6.45 & 2.01 & 6.88 \\
\hline SOX14 & ED & & -0.24 & -1.19 & -1.04 & 1.02 \\
\hline
\end{tabular}

${ }^{1}$ GSE6791-Pyeon et al.(2007),Cancer Res;67(10):4605-19

${ }^{2}$ GSE6791-Espinosa et al.(2012)-PLoS One;8(2):e55975

\subsection{Confirmação e Validação dos Candidatos a drivers por RT-qPCR, qPCR e Pirosequenciamento ( Tumor vs Normal)}

A identificação de candidatos a drivers pela metodologia de integração de dados levou a seleção de um subconjunto de genes e regiões, com base em critérios específicos, que foram submetidos à confirmação e validação por metodologias independentes. Os genes apresentados a seguir foram validados no estudo de Busso (2012).

Para a validação pela metodologia de RT-qPCR foi utilizado um conjunto com $34 \mathrm{CaPe}$ e quatro glandes normais. Foi detectada expressão diminuída dos transcritos nos tumores de pênis em relação aos tecidos normais para os genes PPARG $\left(p=1,2 x 10^{-2}\right), C A V 1\left(p=1,3 \times 10^{-2}\right)$ e FLI1 $\left(p<1 \times 10^{-3}\right)$ e aumento nos níveis para TNFSF10 $\left(p=1,7 \times 10^{-3}\right)$ (Figura 21). Esses genes apresentaram o mesmo sentido de alteração detectado por expressão gênica em larga escala. Não foi encontrada alteração nos níveis de expressão em CaPe para o gene $P M L\left(p=2,2 \times 10^{-1}\right)$. Também foi realizada a comparação entre os níveis de expressão gênica dos quatro genes (PPARG, CAV1, TNFSF10 e FLI1) entre dois grupos classificados quanto à infecção pelo HPV e não foi observada diferença na expressão destes genes entre os grupos. 
A

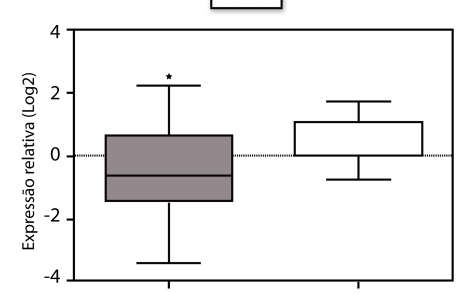

C

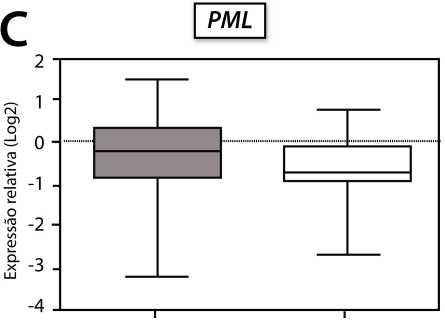

E

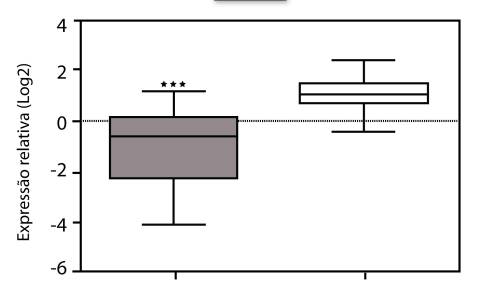

B
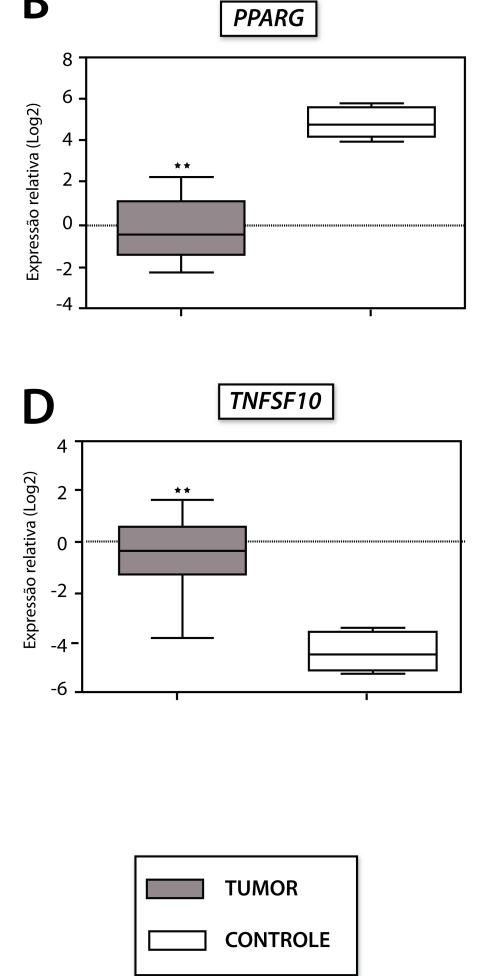

Figura 21: Expressão gênica para os candidatos a drivers detectados pela análise integrada em $\mathrm{CaPe}$ (Tumor vs Normal). Os níveis de transcritos foram avaliados para CAV1 (A), PPARG (B), PML (C), TNFSF10 (D) e FLI1 (E) por RT-qPCR e comparados entre amostras normais e tumorais. Foi observada expressão aumentada para TNFSF10 (F) e diminuição nos níveis de PPARG $(\mathbf{D}), C A V 1(\mathbf{A})$ e FLI1 (E). Não foi encontrada alteração de expressão significativa para o gene $P M L(\mathrm{C}) .{ }^{* *} p \leq 1 \times 10^{-2}$.

Quanto ao número de cópias genômicas, os genes DLC1, PPARG e TNFSF10 foram validados por qPCR. Os resultados obtidos para os quatro genes foram comparados com as características clínicas e patológicas dos pacientes com carcinoma de pênis. Com relação às análises estatísticas, foi utilizado o teste de Qui-quadrado, com limiar de significância $p \leq 5 \times 10^{-2}$ e a análise de sobrevida foi realizada para pacientes com dados de CSS disponíveis utilizando-se o teste log rank e $p \leq 5 \times 10^{-2}$.

Dois dos três genes avaliados apresentaram correlação significativa entre alterações em regiões exônicas e características clínicas e patológicas, sendo duas regiões para $D L C 1$ ( $D L C 1$-3, éxon 2 e DLC1-7, éxon 5), e uma para TNFSF10 (TNFSF10-3, éxon 3) (Tabela 22). Foi observada correlação com bom prognóstico para a região alterada de TNFSF10 (relação com baixo grau histológico e estadio clínico, ausência de invasão perineural, margens cirúrgicas livres e ausência de metástase linfonodal). Já as perdas em duas regiões genômicas de $D L C 1$ associaram-se a características de pior prognóstico da doença, como presença de invasão perineural $\left(p=2 \times 10^{-2}\right)$ e margens cirúrgicas comprometidas $\left(p=3,7 \times 10^{-2}\right)$ para $D L C 1-3$ e $D L C 1$ - 7 , respectivamente. A comparação entre as alterações genômicas e a sobrevida dos pacientes não revelou diferenças significativas. 
Tabela 22: Correlação entre resultados obtidos por qPCR e características clínicas e patológicas de 34 pacientes com carcinoma de pênis. E: éxon

\begin{tabular}{|c|c|c|c|c|c|}
\hline Gene & Local* & Descrição & Grupos & $\begin{array}{l}\text { Casos-total / } \\
\text { Casos-alteração }\end{array}$ & P-valor \\
\hline \multicolumn{6}{|l|}{$D L C 1$} \\
\hline \multirow[t]{2}{*}{$D L C 1-3$} & E-2 & Invasão perineural & Sim & $8 / 7$ & $2 x 10^{-2}$ \\
\hline & & & Não & $13 / 6$ & \\
\hline \multirow[t]{2}{*}{$D L C 1-7$} & & Margens cirúrgicas & Livres & $20 / 7$ & $3,7 \times 10^{-2}$ \\
\hline & E-5 & & Comprometidas & $6 / 5$ & \\
\hline \multicolumn{6}{|l|}{ TNFSF10 } \\
\hline \multirow[t]{10}{*}{ TNFSF10-3 } & E-3 & Grau histológico & $\mathrm{I}$ & $7 / 7$ & 0,000 \\
\hline & & & II-III & $24 / 4$ & \\
\hline & & Estadio clínico & I-II & $12 / 8$ & $3,4 x 10^{-2}$ \\
\hline & & & III-IV & $12 / 3$ & \\
\hline & & Invasão perineural & Sim & $8 / 0$ & $1,4 \times 10^{-2}$ \\
\hline & & & Não & $13 / 8$ & \\
\hline & & Margens cirúrgicas & Livres & $16 / 9$ & $4,2 \times 10^{-2}$ \\
\hline & & & Comprometidas & $7 / 0$ & \\
\hline & & Metástase linfonodal & Sim & $8 / 0$ & $2,3 \times 10^{-2}$ \\
\hline & & & Não & $8 / 4$ & \\
\hline
\end{tabular}

Por pirosequenciamento foram validados os genes TWIST1 e SOX17. Foi utilizado um conjunto de 88 amostras, sendo $47 \mathrm{CaPe}, 28$ tecidos normais adjacentes, 11 glandes, um controle $100 \%$ metilado e um controle $0 \%$ metilado (Figura 22). Os genes foram validados com significância definida por $p<1 \times 10^{-4}$.

Os genes SOX17 e TWIST1 mostraram correlação significativa $\left(p<1 x 10^{-3}\right.$ e $p<5,2 x 10^{-2}$, respectivamente) entre os níveis de metilação e expressão de transcritos. A comparação entre metilação e parâmetros clinico-patológicos revelou que o baixo nível de metilação do SOX17 foi associado com pior prognóstico $\left(p=1,2 \times 10^{-2}\right)$. 

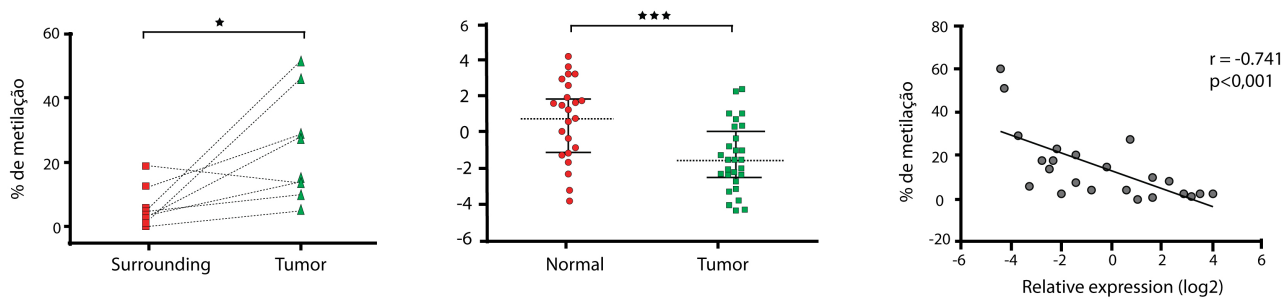

TWIST1
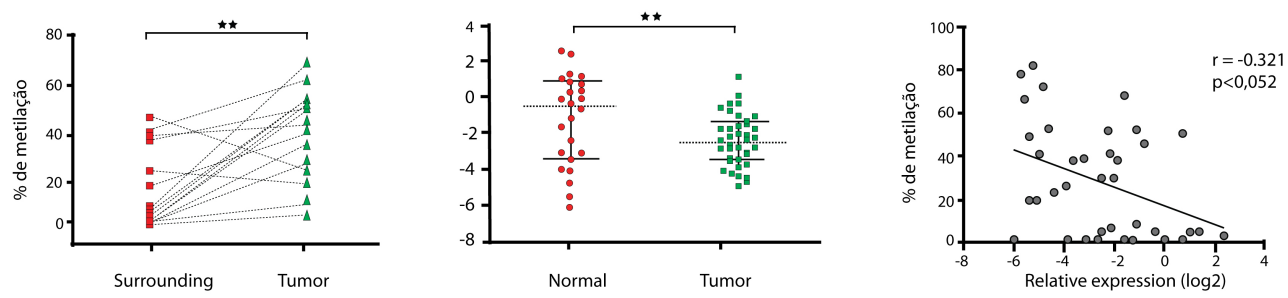

Figura 22: Representação gráfica da correlação entre os níveis de metilação, expressão gênica e correlação de Spearman para os genes SOX17 e TWIST1. A figura apresenta a metilação por pirosequenciamento (primeira coluna), expressão gênica por RT-qPCR (segunda coluna) e correlação de Spearman (terceira coluna).

\subsection{Confirmação e Validação dos Candidatos a drivers por RT-qPCR e Pi- rosequenciamento ( $\mathrm{HPV}+$ vs $\mathrm{HPV}-$ )}

Para a validação pelo método de RT-qPCR foram utilizadas $34 \mathrm{CaPe}$, sendo 11 positivos e 23 negativos para infecção pelo HPV. Foram avaliados os genes $R F C 4$ e PCNA. Os resultados obtidos para os dois genes estão representados na Figura 23. Foi observado um aumento significativo na expressão do gene $\operatorname{RFC}_{4}\left(p=2 \times 10^{-2}\right)$ em amostras de carcinoma de pênis positivas para HPV quando comparadas a tumores negativos. A expressão do gene PCNA apresentou tendência a aumento de expressão nos casos positivos para HPV em relação ao grupo negativo; entretanto, essa diferença não foi significativa $\left(p=3 \times 10^{-1}\right)$.

Embora esses candidatos a driver tenham sido selecionados com base em grupos formados de acordo com a infeç̧ão pelo HPV, foi realizada uma comparação entre os valores de expressão obtidos para tumores e 13 prepúcios normais. Todos os genes demonstram expressão diminuída significativa nos tumores em relação aos tecidos normais: $R F C 4\left(p=3 x 10^{-2}\right)$ e PCNA $(p<$ $\left.1 \times 10^{-3}\right)$. Entretanto é importante destacar que esses genes não estavam presentes na lista de candidatos a driver no estudo de CaPe selecionados pela metodologia de integração de dados. 
A

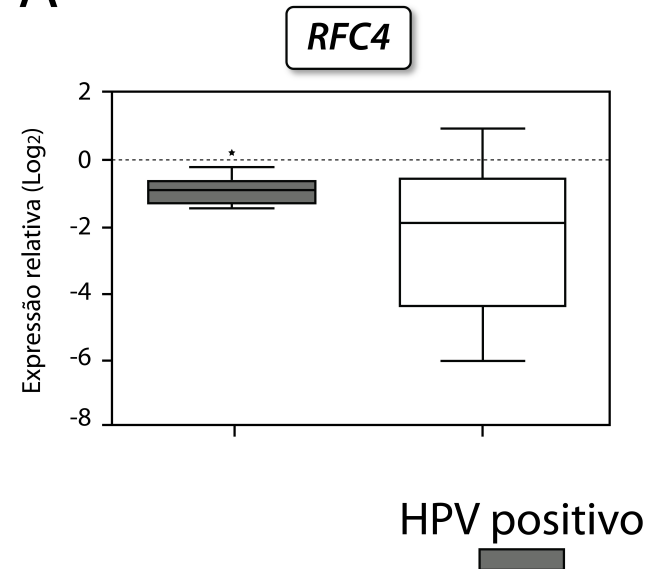

B

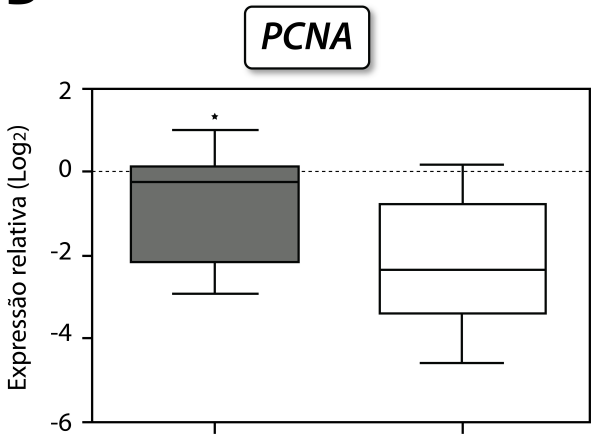

HPV negativo

Figura 23: Expressão relativa dos genes $R F C 4$ e $P C N A$ em amostras positivas e negativas para infecção pelo HPV. Os níveis dos transcritos $R F C 4$ (A) e PCNA (B) foram avaliados por RT-qPCR e comparados entre amostras de CaPe positivas e negativas para infecção pelo HPV. Foi observada expressão aumentada em casos positivos para HPV para os dois genes avaliados. ${ }^{*} p \leq 0,05$. Imagens geradas no programa GraphPad Prism 5.0.

Com relação à validação pela técnica de pirosequenciamento, foi utilizado um conjunto de 55 tumores (18 casos de HPV positivos e 37 casos HPV negativos). Além disso, controles 100\% metilados e $0 \%$ metilados foram incluídos em cada série. Para a análise estatística, foi comparada a média dos sitios $\mathrm{CpG}$ do tecido tumoral e normal. Os dados foram analisados usando SPSS 17.0 (SPSS, Chicago, IL) e GraphPad Prism 5.0 (GraphPad Software Inc., La Jolla, CA). O teste estatístico de Mann-Whitney (U) foi realizado para comparar os casos HPV positivos contra HPVs negativos. Os outliers extremos foram removidos antes da aplicação de testes estatísticos. A Figura 24 apresenta a validação do gene SOX14 pela técnica de pirosequenciamento, com níveis elevados de metilação em amostras positivas para HPV em comparação com amostras negativas para infecção pelo vírus.

\section{SOX14}

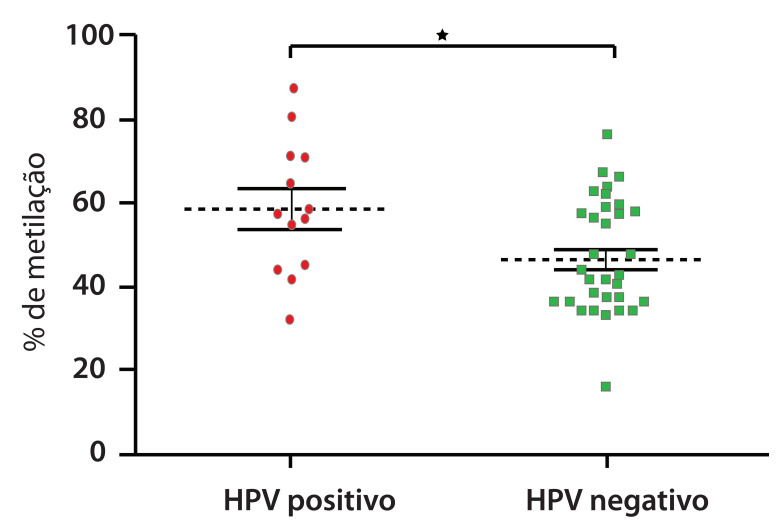

Figura 24: Representação dos níveis de metilação para o gene SOX14 na comparação entre casos positivos e negativos para infecção pelo HPV. Foi utilizado o teste estatístico Mann-Whitney, considerando $p<5 \times 10^{-2}$. 


\subsection{Validação in sílico da Metodologia de Redes em Módulos}

Com o objetivo de avaliar a eficiência do método de redes em módulos adapatado e apresentado nesse estudo com os algoritmos propostos por Segal et al. (2003) e Michoel et al. (2007), foi utilizado um conjunto com 255 amostras de expressão gênica de glioblastoma multiforme (GBM), obtidas no banco de dados TCGA. Como alvo, foi utilizada uma lista com 56 genes relacionados com o GBM identificados no estudo de Frattini et al. (2013). Foram avaliadas (1) a eficiência na detecção de genes importantes $(\mathbf{2})$ as interações verdeiras entre os reguladores e os genes co-expressos dos módulos e (3) quantidade de genes passengers nos módulos. Para que essa análise fosse possível, foram considerados passengers os genes diferencialmente expressos com fold-change $\geq 2,0$, o que resultou na escolha de 651 genes. Considerando a metodologia tradicional de Segal et al. (2003) foram identificados 80 módulos associados a 67 reguladores a partir de uma lista com 2.880 genes diferencialmente expressos. Já o algoritmo proposto por Michoel et al. (2007) identificou 77 módulos associados a 63 reguladores. O método proposto nesse estudo, com a mesma matriz de 2.880 genes, selecionou 45 módulos associados aos respectivos reguladores. A Tabela 23 apresenta os resultados obtidos na avaliação da eficiência para detecção de genes importantes da lista de referência. É possível observar que o método aqui proposto apresentou os maiores valores para sensibilidade e especificidade com 41,8 e 62,7\%, respectivamente. Ainda, é possível observar o maior valor para predições positivas $(51,1)$ e de área sob a curva (53\%). Com relação ao valor da AUC, apesar de baixo, foi maior do que os outros dois métodos avaliados.

Tabela 23: Comparação entre a metodologia proposta neste estudo e a utilizada por Segal et al. (2003) e Michoel et al. (2007) utilizando curva ROC e seus parâmetros. Foi avaliada a eficiência para detecção de genes candidatos presentes na lista de referência. $\mathrm{VPP}=$ valor preditivo positivo, $\mathrm{VPN}=$ valor preditivo negativo, $\mathrm{AUC}=$ área sob a curva.

\begin{tabular}{cccc}
\hline Métrica & $\begin{array}{c}\text { Presente estudo } \\
\mathbf{( 9 5 \%} \mathbf{C I})\end{array}$ & $\begin{array}{c}\text { Segal et al. (2003) } \\
\mathbf{( 9 5 \%} \mathbf{C I})\end{array}$ & $\begin{array}{c}\text { Michoel et al.(2007) } \\
(\mathbf{9 5 \%} \text { CI) }\end{array}$ \\
\hline Sensibilidade & $41,8(39,21-43,91)$ & $36,4(35,71-37,55)$ & $34,5(32,48-36,38)$ \\
Especificidade & $62,7(60,88-64,33)$ & $20,3(18,66-21,49)$ & $25,43(24,07-27,03)$ \\
VPP & $51,1(49,08-52,99)$ & $29,9(28,10-31,86)$ & $30,2(28,77-32,20)$ \\
VPN & $53,6(51,66-54,97)$ & $25,5(24,02-27,88)$ & $29,4(27,1-30,98)$ \\
AUC & $0,53(0,51-0,54)$ & $0,28(0,27-0,29)$ & $0,30(0,28-0,32)$ \\
\hline
\end{tabular}

As interações entre genes co-expressos e reguladores (candidatos a driver) foram comparadas com redes reais, computando o número de arestas que são verdadeiro-positivas (TP), falsopositivas (FP) e falso negativas (FN) e verdadeiro-negativas (TN). Foram obtidas a sensibilidade e especificidade, valor preditivo positivo, valor preditivo negativo e área sob a curva para cada método. Observa-se no presente estudo que a sensibilidade para identificação de interações verdadeiras foi de 20,05 seguido por Michoel et al. (2007) (6,23) e Segal et al. (2003) (3,62). Os valores de sensibilidade e especificidade refletiram-se nas pontuações de VPP, onde o maior valor $(11,21)$ foi identificado para a metodologia proposta, em comparação com os outros dois métodos (5,01 - Segal e 7,02 - Michoel). Para os três métodos avaliados a área sob a curva foi abaixo de 0,5 (0,38 para o presente estudo, 0,34 para Segal et al. (2003) 0,41 para Michoel et al. (2007)). Os dados foram apresentados na Tabela 24 . 
Tabela 24: Comparação entre a metodologia proposta neste estudo e a utilizada por Segal et al. (2003) e Michoel et al. (2007) utilizando curva ROC e seus parâmetros. Foi avaliada a eficiência para detecção de interações entre reguladores e módulos. $\mathrm{VPP}=$ valor preditivo positivo, $\mathrm{VPN}=$ valor preditivo negativo, $\mathrm{AUC}=$ área sob a curva.

\begin{tabular}{cccc}
\hline Métrica & $\begin{array}{c}\text { Presente estudo } \\
(\mathbf{9 5 \%} \text { CI })\end{array}$ & $\begin{array}{c}\text { Segal et al. } \mathbf{( 2 0 0 3 )} \\
\mathbf{( 9 5 \%} \mathbf{C I})\end{array}$ & $\begin{array}{c}\text { Michoel et al.(2007) } \\
\mathbf{( 9 5 \% ~ C I )}\end{array}$ \\
\hline Sensibilidade & $20,05(17,22-23,13)$ & $3,62(2,56-4,96)$ & $6,23(4,60-8,23)$ \\
Especificidade & $56,48(54,58-58,36)$ & $70,90(69,04-72,71)$ & $77,39(75,76-78,95)$ \\
VPP & $11,21(9,56-13,04)$ & $5,01(3,55-6,84)$ & $7,02(5,19-9,26)$ \\
VPN & $72,05(70,08-73,96)$ & $63,42(61,57-65,25)$ & $75,07(73,42-76,67)$ \\
AUC & $0,38(0,36-0,40)$ & $0,34(0,32-0,36)$ & $0,41(0,39-0,44)$ \\
\hline
\end{tabular}

$\mathrm{Na}$ avaliação de genes passengers nos módulos foi observado o maior valor de sensibilidade e especificidade para o método proposto, com 31,34\% e 84,85\% respectivamente. Também foi observada a maior quantidade de acertos na detecção de passengers quando comparados com a lista de referência (23,86\%). Seguido pelos métodos de Michoel et al. (2007) (4,84\%) e Segal et al. $(2003)(4,69)$. Foi observado um alto valor de AUC no método proposto $(0,78)$ em comparação com os outros dois métodos (Segal et al. (2003) com AUC=0,46 e Michoel et al. (2007) com $\mathrm{AUC}=0,44)$. Os dados foram apresentados na Tabela 25 .

Tabela 25: Comparação entre a metodologia proposta neste estudo e a utilizada por Segal et al. (2003) e Michoel et al. (2007) utilizando curva ROC e seus parâmetros. Foi avaliada a eficiência para deteç̧ão de genes passengers nos módulos. $\mathrm{VPP}=$ valor preditivo positivo, $\mathrm{VPN}=$ valor preditivo negativo, $\mathrm{AUC}$ = área sob a curva.

\begin{tabular}{cccc}
\hline Métrica & $\begin{array}{c}\text { Presente estudo } \\
\mathbf{( 9 5 \%} \mathbf{C I})\end{array}$ & $\begin{array}{c}\text { Segal et al. (2003) } \\
\mathbf{( 9 5 \%} \mathbf{C I})\end{array}$ & $\begin{array}{c}\text { Michoel et al.(2007) } \\
(\mathbf{9 5 \%} \mathbf{C I})\end{array}$ \\
\hline Sensibilidade & $31,34(30,54-32,77)$ & $16,13(15,31-18,02)$ & $16,90(14,88-17,60)$ \\
Especificidade & $84,85(82,11-85,99)$ & $50,31(48,30-51,09)$ & $48,36(47,56-49,20)$ \\
VPP & $23,86(21,00-25,13)$ & $4,69(2,87-5,71)$ & $4,84(3,22-5,80)$ \\
VPN & $89,08(87,07-90,06)$ & $79,84(77,63-81,72)$ & $78,92(77,03-79,76)$ \\
AUC & $0,78(0,77-0,80)$ & $0,46(0,44-0,48)$ & $0,44(0,43-0,46)$ \\
\hline
\end{tabular}

\subsection{Validação in sílico da Metodologia de Integração de Dados}

Para avaliar o desempenho da metodologia de integração de dados foi investigada a capacidade de detecção de genes drivers potencialmente importantes em glioblastoma multiformes disponíveis no TCGA. Para essa etapa de validação, foi considerada apenas a integração de três plataformas devido a falta de amostras de miRNAs relacionadas aos outros níveis de alteração (expressão de mRNA, CNA e metilação). Para a identificação de genes relacionados ao GBM foi utilizada a lista de 56 genes da etapa anterior. Entretanto, nessa etapa ela será utilizada como referência para avaliar a eficiência na detecção de genes envolvidos com a doença. Também foi utilizada a mesma matriz de expressão gênica e os dados de metilação, miRNA e alteração do número de cópias foram obtidos após processamento e controle de qualidade.

Foram pré-selecionados 89 candidatos a driver na primeira etapa e esses genes foram utilizados como alvos na etapa de inferência, onde foram identificados 57 módulos e seus respectivos reguladores. Os quinze primeiros candidatos a driver encontrados foram apresentados na Tabela 26, onde é possível destacar genes como PTEN, RB1, TP53, EGFR e CDKN2A, bem caracterís- 
Tabela 26: Módulos e candidatos a drivers selecionados pela metodologia de integração de dados. Em "drogas descritas"são apresentadas drogas cujos alvos foram identificados como possíveis candidatos a drivers

\begin{tabular}{|c|c|c|c|c|c|c|c|}
\hline GO ID & Categoria & P-Valor & Genes & Passenger/genes módulo & Módulo & \%PPI & Drogas descritas \\
\hline GO:0009987 & Processo celular & $7,4 x 10-{ }^{3}$ & ARNT2 & $4 / 18$ & 2 & $37,5 \%$ & \\
\hline GO:0006816 & Transporte de cálcio & $1,35 x 10-{ }^{2}$ & $C A C N A 1 H$ & $5 / 21$ & 1 & 12 & $\begin{array}{l}\text { Cinnarizine, Flunarizine, Mibefra- } \\
\text { dil, Bepridil, Zonisamide, Isradipine }\end{array}$ \\
\hline GO:0007049 & Ciclo celular & $3 x 10^{-4}$ & $C D K_{4}$ & $7 / 32$ & 3 & $31 \%$ & PD-0332991, Flavopiridol \\
\hline GO:0000074 & Regulação do ciclo celular & $1,1 x 10-{ }^{5}$ & $C D K N 2 A$ & $8 / 35$ & 4 & $35 \%$ & \\
\hline GO:0008371 & Processo biológico & $2,2 \times 10-{ }^{2}$ & COL3A1 & $4 / 18$ & 5 & $25 \%$ & $\begin{array}{l}\text { Collagenase Clostridium Histolyti- } \\
\text { cum }\end{array}$ \\
\hline GO:0006464 & Modificação proteica & $1 x 10-{ }^{2}$ & $E G F R$ & $5 / 22$ & 14 & $31 \%$ & $\begin{array}{l}\text { Cetuximab, AEE 788, Panitumu- } \\
\text { mab, BMS-599626, ARRY-334543, } \\
\text { XL647, Canertinib, Gefitinib, HKI- } \\
272 \text {, PD 153035, Lapatinib, Vande- } \\
\text { tanib, Erlotinib }\end{array}$ \\
\hline GO:0042770 & Resposta a dano ao DNA & $3,8 x 10-{ }^{2}$ & $G M L$ & $4 / 19$ & 7 & $25 \%$ & \\
\hline GO:0042127 & Regulação da proliferação celular & $9,2 x 10-{ }^{3}$ & $N F 1$ & $4 / 16$ & 18 & $30 \%$ & \\
\hline GO:0007165 & Sinalização celular & $2,89 x 10-{ }^{3}$ & PIK3CA & $4 / 22$ & 21 & $29 \%$ & $\begin{array}{l}\text { SF 1126, PX-866, NVP- } \\
\text { BEZ235, 2-(1H-Indazol-4-Yl)- } \\
\text { 6-(4-Methanesulfonylpiperazin- } \\
\text { 1-Ylmethyl)-4-Morpholin-4- } \\
\text { Ylthieno(3,2-D)Pyrimidine, } \\
\text { BKM120, XL147 }\end{array}$ \\
\hline GO:0045786 & Regulação negativa do ciclo celular & $1 x 10-{ }^{5}$ & PTEN & $6 / 19$ & 22 & $27 \%$ & \\
\hline GO:0000075 & Checkpoint do ciclo celular & $6,2 x 10-{ }^{5}$ & $R B 1$ & $7 / 28$ & 23 & $25 \%$ & \\
\hline GO:0030001 & Transporte celular & $1,3 x 10-{ }^{3}$ & SCN9A & $5 / 17$ & 9 & $26,3 \%$ & Lidocaine, Riluzole, Zonisamide \\
\hline GO:0000082 & Transição da fase G1/S & $2,6 x 10-{ }^{4}$ & $S K P 2$ & $7 / 19$ & 0 & $19,4 \%$ & \\
\hline GO:0008283 & Proliferação celular & $5,9 x 10-4$ & TP53 & $8 / 17$ & 14 & $18 \%$ & \\
\hline GO:0008151 & Crescimento celular/manutenção & $1,4 x 10-{ }^{3}$ & TRPV5 & $10 / 21$ & 24 & $23,3 \%$ & \\
\hline
\end{tabular}


ticos por seu envolvimento no câncer. Todos esses genes estavam presentes na lista de referência.

O módulo 4, regulado pelo gene CDKN2A e enriquecido para regulação do ciclo celular (GO:0000074, $p=3 \times 10^{-4}$ ) apresentou $7 / 35$ genes com funções relacionadas com o ciclo celular (CDC2, CDC20, CDC25C, CENPE, CHAF1B, KIFC1 e MCM2). Além disso, 8/35 genes passengers e $35 \%$ de PPI foram identificados no módulo. O módulo 2, enriquecido para vias processo celular (GO:0009987, $p=7,4 x 10^{-3}$ ), foi associado com o gene ARNT2, seu possível regulador. Nesse módulo, foram identificados $37,5 \%$ de interação entre genes co-expressos e candidatos a $d r i$ ver, além de 4/18 genes passengers. Também foram identificados genes importantes como PTEN (enriquecido para via de regulação negativa do ciclo celular, $1 \times 10^{-5}$ ), RB1 (enriquecido para a via do checkpoint do ciclo celular, $6,2 \times 10^{-5}$ ) e TP53 (enriquecido para a via de proliferação celular, $5,9 \times 10^{-4}$ ), amplamente descritos em vários processos tumorais e enriquecidos para vias relacionadas com o ciclo celular. O gene $E G F R$, bem descrito em glioblastoma multiforme, foi associado com o módulo 14, enriquecido para modificação proteica (GO:0006464, $p=1 \times 10^{-2}$ ) e apresenta $31 \%$ de interação física com os genes do módulo. 


\section{DISCUSSÃO}

Biologia de sistemas é um campo multidisciplinar, onde algumas áreas envolvem o estudo de redes reguladoras subjacentes à função celular com o objetivo de identificar o comportamento dos genes que compõe o sistema. Vários estudos na literatura, Gevaert e Plevritis (2013); Li et al. (2012a); Lou et al. (2011) utilizaram dados de expressão, imunoprecipitação da cromatina (ChIP), alteração do número de cópias genômicas, expressão de miRNA e/ou informação funcional a priori para elucidar redes reguladoras. A maioria destes métodos tenta desvendar a lógica do controle da expressão gênica e pode ser utilizada para o estudo de doenças complexas como o câncer, que é caracterizado por uma infinidade de alterações somaticamente adquiridas. Para o estudo da ação integrada de diferentes níveis de alteração em câncer de pênis, foi apresentada nessa tese uma nova metodologia de integração de dados, obtidos por diferentes estratégias, avaliando alterações do número de cópias genômicas (aCGH), análise da expressão de transcritos codificadores (mRNA) e não codificadores (miRNAs) e análise do perfil de metilação do DNA.

Para isto, o estudo foi dividido em duas etapas, onde (1) os genes passaram por um processo de seleção, classificados de acordo com critérios relacionados ao tipo de alteração e correlação e (2) então foi atribuído a esses genes a função de reguladores do conjunto de genes co-expressos (módulos), associados a eles. Como resultado, foram identificados genes com alta frequência de alteração para os quatro níveis testados e inferidos como possíveis reguladores de um módulo. Para o nosso conhecimento, não há estudos de integração de dados em câncer de pênis envolvendo quatro diferentes plataformas para o mesmo conjunto de pacientes. Em adição, os dados em literatura sobre esse tipo de tumor são muito limitados e restritos a investigação de genes e/ou proteínas únicas, ressaltando a importância de estudos moleculares em larga-escala envolvendo alterações genômicas, transcriptômicas e epigenéticas. Segundo Stratton et al. (2009) e Pollack et al. (2002) alterações no DNA são características fundamentais do tumor, contribuindo para a instabilidade genômica e desregulação do gene. A ativação de oncogenes por amplificação ou perda de função de supressores tumorais resultante da deleção de segmentos do DNA são algumas das alterações que podem contribuir para o processo tumoral.

Cada tumor é único, contendo uma grande quantidade de alterações genéticas, das quais, apenas algumas são responsáveis por direcionar a proliferação celular e a metástase (Garraway et al. , 2005). Vogelstein et al. (2013) atribuem às mutações drivers o início e progressão do processo tumoral. Portanto, identificar essas mutações e distinguí-las das passengers (alterações que não oferecem vantagem seletiva ao tumor) tem sido um dos grandes desafios para a caracterização genômica do câncer e foi um dos elementos responsáveis pelo desenvolvimento da metodologia de integração de dados proposta nesse trabalho. Ainda com relação à revisão publicada em 2013 por Vogelstein et al. (2013) foi atribuída uma nova classificação para os genes drivers: mut-drivers (alterações genômicas que conferem vantagem seletiva e direcionam o desenvolvimento tumoral) e epi-drivers (genes que se expressam de maneira aberrante em tumores, mas não estão frequentemente mutados). Aqui, as alterações foram definidas como drivers e passengers, seguindo dois termos bem estabelecidos na literatura atualmente.

Além de alterações genômicas com alta frequência, estudos como o de De-Carvalho et al. 
(2012) associaram genes drivers com eventos epigenéticos relacionados ao câncer. Anteriormente, Jones e Baylin (2002) descreveram que alterações epigenéticas, como a hipometilação, eram responsáveis pela instabilidade genômica e a hipermetilação de ilhas CpGs estava associada à inativação de genes supressores de tumor. Muitas dessas mudanças genômicas no DNA podem afetar o nível de expressão do RNA mensageiro (mRNA), bem como de miRNA, alterando a função do gene e favorecendo a tumorigênese. Todas essas alterações podem ser caracterizadas de diversas maneiras e foram utilizadas como informações essenciais para o desenvolvimento da metodologia proposta.

Como relação aos tumores sólidos (tipo tumoral utilizado nesse estudo), sua formação é uma consequência de muitas mutações sequenciais envolvendo 40-100 genes, dos quais 5-15 são mutações drivers (Parsons et al., 2008; Sjoblom et al. , 2006; Wood , 2007). Com isso, destaca-se a importância do desenvolvimento de novas metodologias para identificação de genes frequentemente alterados e que possam auxiliar no entendimento da formação e progressão tumoral.

A integração de dados entre alteração do número de cópias do DNA e expressão gênica tem sido utilizada como um dos mecanismos para a identificação de mutações drivers (Ambatipudi et al. , 2012; Kuijjer et al. , 2012; Xu et al., 2010). Em estudos epigenéticos, Kalari e Pfeifer (2010) identificaram genes drivers com alta frequência de hipermetilação e hipometilação devido à perda das funções normais da célula e alterações de vias de sinalização. Piepoli et al. (2012) utilizaram 866 miRNAs em 19 amostras de câncer colorretal e 17 amostras de câncer no pâncreas com o objetivo de relacionar a expressão alterada de miRNA com oncogenes e/ou supressores tumorais. Bentink et al. (2012) correlacionaram a expressão alterada de transcritos codificadores e miRNA em câncer de ovário com o objetivo de selecionar alterações drivers que pudessem ser explicadas pelas duas plataformas. Com base nesses relatos, ressalta-se que a identificação de genes drivers e passengers pode ser realizada em estudos independentes, combinando informações obtidas do mesmo paciente ou utilizando dados da literatura.

Entretanto, se as análises com apenas um tipo de informação possibilitam um estudo específico sobre a influência de genes drivers (identificados a priori), as análises combinatórias com diferentes níveis de informações podem assegurar maior confiabilidade à busca. Os genes drivers têm características que se encaixam perfeitamente no conceito de reguladores discutido por Segal et al. (2003). Entretanto apenas estudos posteriores como o de Akavia et al. (2010), utilizando amostras de melanoma, trataram os reguladores como possíveis drivers de doenças. Nenhum deles, porém, discutiu a presença de passengers e interações proteína-proteína com os módulos formados. Segundo os resultados aqui apresentados, os genes passengers auxiliaram na escolha de módulos que apresentavam uma relação mais significativa com os reguladores (drivers), ajudando na seleção de vias possivelmente responsáveis pelo desenvolvimento do carcinoma de pênis.

\section{Metodologia de Integração de Dados}

A metodologia utilizada neste estudo difere de outras já descritas, entre outras coisas, pelo conjunto de dados utilizado. Foram avaliados quatro diferentes níveis de alterações: alteração do número de cópias do DNA (CNA), metilação de ilhas CpGs, expressão de transcritos codificadores (mRNA) e não codificadores (miRNAs), sendo que todos foram obtidos a partir do mesmo conjunto de pacientes. Em uma visão geral, o conceito proposto neste estudo vai além da escolha 
de genes frequentemente alterados. Primeiramente, foram selecionados genes que combinavam melhor o conjunto de modificações nos diferentes níveis de alterações avaliados e posteriormente foram identificados diversos candidatos, incluindo supressores tumorais e oncogenes já descritos em literatura. Esses genes selecionados foram utilizados na inferência de módulos, estabelecendo dessa maneira um complemento para o estudo de drivers, relacionando genes frequentemente alterados com genes presentes em uma cascata de sinalização celular possivelmente envolvida com o desenvolvimento tumoral. Associar um candidato a driver a um conjunto de genes coexpressos, possivelmente regulados por ele, amplia o conhecimento do sistema biológico e do comportamento do gene na célula, abrindo novas perspectivas para futuros estudos das vias enriquecidas para o conjunto módulo-driver e a identificação de marcadores úteis na prática clínica.

Para atender ao objetivo de incorporar informações de genes drivers e passengers no estudo, foram estabelecidos alguns critérios durante a primeira etapa de seleção de candidatos. Após a correlação entre os níveis de alterações avaliados é esperado, por exemplo, que genes com expressão diminuída e com altos níveis de metilação no DNA sejam selecionados, assim como genes com expressão diminuída e perda de segmento do DNA. Porém, além de definir um limiar para os valores de correlação ( $\mathrm{r}>0,3$ e $\mathrm{r}<-0,3$ ), a metodologia considerou algumas peculariaridades, pontuando genes com deleções homozigóticas e amplificações e de acordo com sua classificação no banco de variantes genômicas (DGV). Para um gene com deleção homozigótica é esperada expressão diminuída, pois há perda de ambos os alelos. No caso de uma deleção hemizigótica, a expressão diminuída pode ser ocasionada por um processo de metilação da região promotora do gene ou ação pós transcricional, por exemplo, envolvendo a regulação por miRNAs. Como todas as alterações foram identificadas com alta frequência, a utilização de mecanismos concordantes que expliquem a expressão alterada de transcritos codificadores aumenta o poder da análise para a identificação de candidatos a drivers. As características de cada um destes mecanismos podem ser responsáveis pela definição do grau de importância daquele gene no tumor estudado. Os genes selecionados (alvos) a partir de múltiplos conjuntos de dados podem ser utilizados em diversos estudos, como por exemplo, os de inferência de redes gênicas e modelos probabilísticos. O sucesso desses modelos aplicados a doenças depende diretamente da matriz de genes utilizada pelos algoritmos, ressaltando a importância da seleção a priori de genes candidatos.

A inclusão de genes passengers como um dos critérios de seleção de módulos reforça a identificação de conjuntos de genes alterados que possam estar relacionados com vias diretamente envolvidas com o desenvolvimento de doenças. Seguindo os critérios definidos por Vogelstein, foram considerados passengers aqueles genes que possuiam algum tipo de alteração, porém não ofereciam vantagem ao tumor. Com esse tipo de informação foram selecionados diversos módulos diretamente relacionados com ciclo celular, sistema inflamatório e resposta imune.

Segundo McFarland et al. (2013) mutações em genes passengers geralmente resultam em pouco efeito na progressão tumoral. Porém é preciso destacar duas situações. A primeira é com relação à função do gene passengers e o impacto que essa alteração pode ter na formação de uma proteína e seu papel na célula. No caso de um gene considerado passengers com função de transcrição, é possível que ocorra alterações significativas favorecendo células cancerígenas. Outra situação é o acúmulo de genes passengers em uma determinada via possivelmente relacionada com o desenvolvimento tumoral. Nessa situação, um gene driver pode desencadear uma 
cascata de sinalização por genes dessa via, resultando em adaptação da mesma para favorecer as células do tumor. Nessa via, algumas mudanças epigenéticas, genômicas e transcriptômicas podem potencializar ainda mais o papel dessa via a favor da doença. Em alguns estudos com pacientes tratados por quimioterapia é possível que a ação de fármacos em alvos específicos resulte em efeitos colaterais sobre os genes vizinhos desses alvos, promovendo alterações passengers que podem apresentar um papel essencial na comunicação celular e favorecer a formação do tumor por outros mecanismos.

A inclusão de dados também favorece a predição por métodos probabilísticos auxiliando a escolha de alvos com maior precisão. Nesse caso, a inclusão de genes passengers auxiliou na escolha de módulos que pudessem ter maior proximidade com o desenvolvimento do câncer de pênis, devido à utilização de dados obtidas a partir dos mesmos conjuntos de pacientes. A utilização de dados externos sobre genes bem descritos pelo seu envolvimento no câncer ou conjuntos de fatores de transcrição, oncogenes e supressores tumorais foi utilizado como uma informação adicional, mas não como critério de seleção a priori. O objetivo de não utilizar esse tipo de informação foi não tendenciar a escolha de genes potencialmente responsáveis pelo tipo específico de carcinoma estudado, o que só foi possível pelo conjunto de quatro plataformas utilizadas.

Para a validação da metodologia de integração de dados proposta no presente estudo, foram selecionadas 255 amostras de glioblastomas multiforme no TCGA avaliadas de acordo com a expressão de transcritos codificadores, metilação de DNA, alteração do número de cópias e expressão de miRNAs, além de uma lista de referência com 56 genes envolvidos com o desenvolvimento do GBM, incluindo alguns genes drivers já identificados. Dentre os quinze primeiros genes candidatos a drivers selecionados, foi possível destacar os genes CDKN2A, EGFR, PTEN, RB1 e PIK3CA. O estudo de Cen et al. (2012), utilizando amostras de pacientes com glioblastoma multiforme, identificou alterações no gene $C D K N 2 A$, um gene supressor tumoral importante cuja função é interromper o ciclo celular na fase G1, inibindo a ligação de $C D K 4 / 6$ com ciclina D1 e impedindo a fosforilação da proteína supressora tumoral Rb e E2F inativo. Além do gene CDKN2A, os genes $P T E N$ e $R B 1$ também foram associados a módulos enriquecidos para vias relacionadas com o ciclo celular. É possível que esses genes candidatos a drivers estejam diretamente relacionados com o desenvolvimento da doença e sejam responsáveis por adaptações promovidas pelo tumor no ambiente celular. Também foi identificado o gene TP53, localizado na região 17p13.1, como regulador do módulo 14, enriquecido para a via de proliferação celular $\left(p=5,9 \times 10^{-4}\right)$. Esse gene apresentou altos níveis de metilação da região promotora como mecanismo concordante para a expressão diminuída encontrada. Além disso, o módulo 14 apresentou 8/17 genes com funções relacionadas ao ciclo celular e $18 \%$ de interações proteína-proteína. Ainda com relação aos resultados obtidos em GBM, os genes CHK1, CHK2, SFN, CDC25A e CDK1 foram selecionados como passengers e relacionados com a via do TP53, sugerindo que a mutação desse candidato a driver e o acúmulo de passengers estejam relacionados a uma via essencial para o desenvolvimento do GBM. Concordante com os resultados obtidos, Verhaak et al. (2010), utilizando a integração de dados genômicos e transcriptômicos em 200 amostras de glioblastoma multiforme (classificadas como proneural, neural, clássica e mesenquimal), relataram alterações significativas nos genes PTEN (subtipo mesenquimal), TP53 (subtipo neural) e CDKN2A, EGFR e RB1 (subtipo clássico) Frattini et al. (2013), integrando dados de alterações somáticas e regiões genô- 
micas alteradas de GBM, identificaram translocações recorrentes do gene $E G F R$, onde a fusão EGFR-SEPT14 foi mais frequente em glioblastomas humanos. A fusão de EGFR-SEPT14 ativa a sinalização de $S T A T 3$, conferindo sensibilidade à inibição de $E G F R$.

\section{Adaptação no Método de Redes em Módulos}

Modelos probabilísticos (e.g. Redes Bayesianas) aplicados a dados biológicos permitem descrever as observações para cada uma das variáveis (genes) como uma função de um número limitado de reguladores, reconstruindo a rede de regulação subjacente às observações. Em redes Bayesianas, cada gene é associado com o seu programa de regulação individual, i.e., o seu próprio conjunto de pais e de distribuição de probabilidade condicional. Friedman et al. (2000) foram pioneiros no uso de redes reguladoras a partir de dados de expressão gênica. Em seu estudo, foram selecionados 800 genes, obtidos a partir de 76 amostras de Saccharomyces cerevisiae, porém, por razões computacionais apenas 250 genes foram escolhidos para as análises. Pe'er et al. (2001) avaliaram 565 genes mutados, obtidos a partir de 300 amostras de Saccharomyces cerevisiae para inferência de subredes a partir de perfis de expressão com perturbação e identificaram uma variedade de vias metabólicas, de sinalização e regulatórias. Em ambos os relatos, é possível destacar o problema da dimensionalidade (e.g., um grande número de características e parâmetros para um limitado conjunto de amostras), que também proporciona limitações de inferência nos dias atuais. A utilização do modelo de redes em módulos como mecanismo de associação entre candidatos a driver e conjuntos de genes co-expressos foi uma das abordagens do presente estudo para superar esses problemas de inferência. Segal et al. (2003) foram os primeiros a descrever redes em módulos, ou seja, genes agrupados em módulos, partindo dos mesmos reguladores e com a mesma distribuição condicional. À medida que o número de parâmetros a serem estimados em uma rede em módulo é muito menor do que em uma rede de Bayesiana, os conjuntos de dados de expressão gênica disponíveis podem ser grandes o suficiente para a realização de uma inferência satisfatória, como demonstrado por vários autores (Battle et al. , 2005; Segal et al. , 2003, 2005; Xu et al. , 2004). Bonnet et al. (2010) utilizaram as redes em módulos para identificar miRNAs reguladores de módulos gênicos. Entre os 76 módulos encontrados pelos autores, 44 foram enriquecidos com p $<0,05$ pelo Gene Ontology, a partir de 2.987 genes com os quais os miRNAs foram relacionados.

Apesar do sucesso demonstrado pelos algoritmos de redes em módulos na identificação de relações biologicamente relevantes, há questões em aberto sobre a utilização do método em determinados tipos de doença devido à complexidade e especificidade dos genes envolvidos no processo tumoral. Michoel et al. (2007) utilizaram a amostragem de Gibbs (Geman e Geman. , 1984) para atualização constante das atribuições entre módulos e moduladores, durante o programa de regulação, de acordo com cada gene e condição. Além disso, tanto o método de Michoel et al. (2007) quanto o de Segal et al. (2003) utilizaram unicamente uma anotação funcional (e.g. o Gene Ontology) como mecanismo de associação entre genes e suas funções biologicas. Porém há diversos problemas nessa etapa devido a ambiguidade, falta de anotação adequada e polarização do espaço de anotação (e.g., o código GO: 0050789, referente à regulação do processo biológico, inclui mais de $44 \%$ de todos os genes humanos anotados para processos biológicos). Com isso, fica comprometida a utilização do enriquecimento como único mecanismo de associação de genes a vias, assumindo que genes reguladores são responsáveis pela alteração de um determinado pro- 
cesso biológico. O fato de um gene ser o regulador de um módulo não satisfaz a condição de que há uma relação direta entre eles. Após pesquisas realizadas no NCBI (acesso em 19/11/2013), não foram encontrados artigos que utilizassem os conceitos de drivers e passengers como etapas importantes durante o processo de seleção dos módulos. Também não foram encontrados estudos que identificassem genes presentes em módulos com interações proteína-proteína. Uma das contribuições do presente estudo foi incorporar essas informações na metodologia de redes em módulos. Uma vez que genes passengers podem apresentar funções essenciais em diversas vias biológicas, a relação entre esses genes e drivers necessita de uma interação direta para que a via seja associada ao desenvolvimento do câncer.

A validação in silico permitiu avaliar a eficiência da metodologia de redes em módulos adaptada com a inclusão de novas informações (passengers e PPI) e como essas alterações poderiam influenciar na escolha de importantes genes reguladores. Nessa etapa foram utilizadas 255 amostras de glioblastomas multiforme avaliadas por microarrays de expressão. Utilizando medidas de precisão positivas, área sob a curva (AUC), sensibilidade e especificidade foi avaliada a eficiência da inclusão dos dados propostos no algoritmo, em comparação com o método de Segal et al. (2003) e Michoel et al. (2007). Foi observado que a abordagem utilizada nesse estudo apresentou os maiores valores para sensibilidade, especificidade, AUC e predições positivas quando avaliada a capacidade do método em identificar genes passengers e reguladores presentes em uma lista de referência. Também foi observado que o método apresentou baixa sensibilidade e especificidade para detecção de interação proteína-proteína quando comparado com os outros dois métodos, mas é importante ressaltar que a predição positiva de interações foi maior no método proposto, indicando que essa abordagem é mais eficiente em selecionar genes co-expressos interagindo fisicamente com genes reguladores. É importante ressaltar também que essas comparações tiveram o objetivo de avaliar as alterações propostas no algoritmo e que os outros dois métodos avaliados não se propõem a identificar genes drivers ou incluir passengers e interações proteína-proteína.

Especificamente sobre a seleção dos módulos pela metodologia de Segal et al. (2003), foram identificados 67 reguladores atribuídos a 80 módulos para um total de 2.880 genes co-expressos. Entretanto, poucas interações foram confirmadas quando utilizados bancos de dados de interação proteína-proteína após a comparação com a rede de referência. Com o mesmo conjunto de dados, a metodologia proposta neste estudo identificou 45 módulos atribuídos aos seus respectivos reguladores para um total de 855 genes co-expressos. A utilização de PPIs foi responsável pela formação de módulos menores e, em sua maioria, enriquecidos significativamente para processos biológicos compostos por grupos de genes que apresentaram maior interação entre eles. Isso pode ser explicado pela alteração feita no programa de regulação, com a inclusão das interações proteína-proteína, eliminando módulos com frequência PPI inferior a 10\%. Também foi observado que das 855 interações existentes, 220 (25,8\%) coincidiam com a rede de referência. Em Segal et al. (2003), 3,9\% das interações foram confirmadas para todos os módulos, sendo que nos trinta primeiros módulos selecionados, apenas três apresentaram $10 \%$ de interações proteínaproteína confirmadas pela rede original (critério pré-estabelecido para a seleção do módulo).

É importante ressaltar que devido à utilização desse critério, é possível que alguns genes sejam eliminados dos módulos, prejudicando o processo de enriquecimento. Porém, módulos com interações físicas em maior quantidade, sugerem que as interações existentes entre drivers e genes co-expressos possam ser diretamente responsáveis pela escolha de genes candidatos a drivers e 
biologicamente eficientes na cascata de sinalização celular durante o desenvolvimento da doença.

O gene CDKN3 (inibidor de quinase 3 dependente de ciclina), regulador do módulo 12 (composto por 20 genes) pelo método de Segal et al. (2003) também foi identificado como regulador do módulo 8 (enriquecido para ciclo celular e composto por 18 genes), na metodologia proposta. Sete dos 18 genes apresentavam função relacionada com o ciclo celular e foram identificadas $20 \%$ de PPI, concordante com a rede de referência. O gene $C D K N 3$ foi identificado com expressão aumentada e hipometilado em comparação com tecido normal. Esse gene, mapeado na região 14q22, codifica uma proteína localizada em regiões perinucleares que interage e desfosforila $C D K 2$, impedindo sua ativação e desregulando a transição das fases G1/S do ciclo celular (Nalepa et al. , 2013). Em um estudo com 83 amostras de GBM, Yu et al. (2007) relataram uma menor sobrevida em casos que apresentavam aumento da expressão de $C D K N 3$. Com relação à influência epigenética na regulação do $C D N K 3$, Niculescu et al. (2004) relataram em neuroblastomas a hipometilação da região promotora associada com aumento de expressão do transcrito, levando a mudanças no ciclo celular devido a desfosforilação de quinase dependente de ciclinas (CDK). Esses resultados sugerem a importância do CDNK3 durante o desenvolvimento dos glioblastomas e confirmam a seleção desse gene como um candidato a driver em ambas as metodologias utilizadas.

Em 2003 quando Segal e colaboradores propuseram sua metodologia de redes em módulos poucas informações estavam disponíveis sobre interações entre proteínas e métodos para obtenção de tais interações. Muitas interações depositadas em bancos de dados foram identificadas pela técnica Y2H ( Yeast Two Hibrid), onde uma proteína de interesse X é ligada ao domínio de ligação ao DNA (DBD), construindo assim uma "isca". A proteína com possível interação, Y, é ligada ao domínio de ativação (AD), chamada de "presa". A isca, ou seja, DBD-X se liga a sequência upstream (UAS) do promotor. A interação AD-Y se liga a DBD-X e, portanto reconstitui o fator de transcrição funcional, com ação posterior da RNA polimerase II e transcrição do gene repórter. Essa técnica gera muitos falso-negativos, ou seja, interações proteína-proteína que não podem ser detectadas devido às limitações do método de leitura. Um exemplo dessa limitação, conforme relatado por Brukner et al. (2009), são as proteínas de membrana, dificilmente detectadas pela técnica Y2H clássica devido a diferença entre o meio condutor e meio oxidativo extracelular. A localização das interações, nesse caso, pode interferir nos resultados, pois a diferença entre o meio abordado na técnica utilizada e o meio natural de ocorrência das interações pode resultar na falta de fatores importantes, possivelmente responsáveis por estas interações. Segundo Brukner et al. (2009), estima-se que a taxa de falso-positivos seja de 25 a $45 \%$ no sistema Y2H. No presente estudo, esse viés foi considerado e sua possível correção se deu com a utilização de múltiplos bancos de dados de interação (como descrito em Materiais e Métodos). Atualmente, outras técnicas mais confiáveis estão sendo utilizadas para detectar as PPIs, como por exemplo, espectrometria de massa, dependente da digestão proteolítica que produz uma coleção de peptídeos que são ionizados por eletronebulização ou por dessorção a laser auxiliada por matriz (Pennington e Dunn , 2001). As análises podem ser realizadas a partir de íons de peptídeos intactos (espectrometria de massa ou MS) - fingerprint - ou de peptídeos fragmentados (espectrometria de massa em tandem ou MS/MS). Nas análises de fingerprinting, os valores massa $(\mathrm{m}) /$ carga $(\mathrm{z})$ dos peptídeos intactos são correlacionados às proteínas de um banco de dados específico, o que torna esse método aplicável somente às espécies com genomas sequenciados. Já na espectrometria de massas 
em tandem, a fragmentação dos peptídeos em aminoácidos possibilita determinar a relação $\mathrm{m} / \mathrm{z}$ desses resíduos identificando-se a sequência de aminoácidos, o que torna possível trabalhar com genomas não sequenciados e moléculas desconhecidas (Aebersold e Goodlett, 2001).

\section{Limitações das Plataformas e Meta-Análise}

Os dados de alterações do número de cópias genômicas, expressão de transcritos codificadores e metilação utilizados no presente estudo foram obtidos a partir de plataformas de oligoarrays, onde a cobertura dos genes conhecidos é feita de acordo com sua anotação no RefSeq (disponível em www.ncbi.nlm.nih.gov/refseqâĂÖ) e GenBank (disponível em www.ncbi.nlm.nih.gov/ genbankâĂŐ). A plataforma Human Genome CGH microarray Kit, 4x44K (Agilent Technologies), contém cerca de 42.494 sondas com tamanho de 60 bases e resolução espacial média de aproximadamente $75 \mathrm{~kb}$. Para a detecção de perdas e ganhos de segmentos genômicos, foi considerado o uso de cinco sondas consecutivas, concordando com diversos artigos sugeridos pela empresa responsável pelas plataformas. Entretanto, em uma análise detalhada dos resultados é possível verificar que algumas sondas sequer cobrem os genes com deleções ou amplificações, devido à baixa cobertura e grande espaçamento entre elas (aproximadamente $1.000 \mathrm{~kb}$ ). A cobertura de uma região genômica alterada com cinco sondas consecutivas é pouco sensível se comparada com plataformas como as da Affymetrix (CytoScan HD), onde são consideradas, no mínimo, 50 sondas consecutivas. Entretanto, a plataforma Agilent 4x44k ainda é bastante utilizada por diversos grupos, com resultados satisfatórios (He et al. , 2013; Jovov et al. , 2012; Remy et al. , 2013; Zhang et al. , 2013b).

Ainda com relação à caracterização das alterações, em teoria, a deleção de um único nucleotídeo codificante pode causar uma mutação frameshift levando a codificação de uma proteína truncada. Embora a deteç̧ão de deleções de nucleotídeos exija essencialmente o sequenciamento, deleções muito pequenas abrangendo um ou poucos genes têm sido fundamentais na clonagem de importantes supressores tumorais (Rothenberg e Settleman , 2010). Deleções focais em linhagens celulares de câncer foram fundamentais para a identificação do gene $C D K N 2 A / B$ como um dos alvos mais comuns de inativação genética em cânceres humanos (Kamb et al. , 1994). A deleção de apenas 25 nucleotídeos (abrangendo um limite exon-íntron e levando ao splicing alternativo) foi fundamental para relacionar o gene WT1 com o tumor de Wilms (Call et al. , 1990; Haber et al. , 1990).

É importante considerar que para aCGH, a medição precisa de perdas genômicas é inerentemente mais difícil do que a detecção de amplificações, uma vez que as perdas são limitadas a apenas uma ou duas cópias, e nenhum sinal residual será extremamente próximo dos limites inferiores de detecção da plataforma que está sendo utilizada. Pequenas deleções que consistem em uma ou poucas sondas genômicas com sinais de hibridação um pouco acima do background podem facilmente ser desconsideradas devido a um ruído significativo associado à medição simultânea de centenas de milhares de marcadores genéticos.

A sensibilidade para detectar deleções devido a esses fatores limitantes contrasta com relação às regiões cromossômicas pelo aumento do número de cópias, que podem abrigar novos oncogenes. Ao contrário da inativação de genes supressores, ganhos de segmentos genômicos podem levar à ativação de oncogenes promovendo o aumento da expressão dos transcritos que pode se estender a todo o comprimento do gene alvo (e, muitas vezes, abrangem vários genes). Além disso, o grau 
de amplificação pode ser muitas vezes o número de cópias diplóide e, portanto, menos sujeito aos ruídos do sinal de background ou contaminação.

Com relação à análise de expressão gênica, a mesma plataforma, Agilent 4x44k, foi utilizado e, como descrito anteriormente, há limitações com relação à cobertura das sondas. Ao analisar os dados de expressão gênica, alguns oligonucleotídeos de 60pb não apresentaram cobertura correspondente à lista de genes disponibilizada pelo fabricante, pois se alinhavam com os transcritos de mais de um gene. Gertz et al. (2009) relatam ao menos 10 estudos que utilizaram plataformas Agilent 4x44k para expressão gênica (Bhatia et al. , 2008; Cao et al. , 2009; Galliher-Beckley et al. , 2008; Hao et al. , 2008; Kalie et al. , 2008; Konishi et al. , 2009; Mattsson et al. , 2008; Tiwari et al. , 2008; Verstraelen et al. , 2009; Vuillaume et al. , 2009), e que apresentavam uma descrição pouco detalhada sobre os métodos de hibridação e análise. Ainda segundo o autor, nenhum deles considerou a correção do mapeamento das sondas e apenas os estudos de Bhatia et al. (2008) e Mattsson et al. (2008) descreveram algumas etapas para restringir a análise apenas para sondas que apresentam genes bem descritos. Por esse motivo, foi realizada uma anotação sistemática de todos os cromossomos (como descrito em Materiais e Métodos. pág. 71) com a exclusão de 6.253 sondas. Assim, como na plataforma de aCGH, a resolução para expressão gênica é limitada e segue parâmetros semelhantes para espaçamento e tamanho das sondas. A ausência de um tratamento prévio desses dados aumenta a chance de seleção de genes com erros de anotação e mapeamento, invalidando possíveis achados.

Para a análise de metilação do DNA, a plataforma de $244 \mathrm{k}$ da Agilent disponibiliza cerca de 237.220 sondas para cobrir aproximadamente 27.000 ilhas CpGs, incluindo 95pb extras para regiões flanqueadoras e espaçamento médio de 100pb. Cada sonda é associada ao gene correspondente de acordo com anotações pelo UCSC (disponível em http://genome.ucsc.edu/). Nesse caso, a cobertura é mais robusta devido a maior quantidade de sondas cobrindo as 27 mil ilhas e com espaçamento menor. Entretanto, assim como nas outras plataformas (Agilent 4x44 para aCGH e microarray de expressão), é possível que ruídos resultantes do processo de marcação com cianinas influenciem no resultado, uma vez que um gene é considerado hipermetilado ou hipometilado de acordo com a intensidade do sinal processado obtido pela razão entre $\mathrm{Cy} 3 / \mathrm{Cy} 5$ na comparação entre tecido tumoral e normal. É importante ressaltar que o estudo das alterações epigenéticas em carcinoma de pênis utilizou dois protocolos: MCIp e McrBC para enriquecimento da porção metilada e não metilada das ilhas CpGs e além do possível viés nas técnicas de array em ambos os protocolos, a análise de dados obtidos a partir da plataforma 244K Agilent ainda é controversa, com poucos artigos disponíveis e para o nosso conhecimento, nenhum pipeline ou programa fornecido pela empresa que leve em consideração as especificações das alterações epigenéticas.

A análise de miRNAs diferencialmente expressos pela técnica de TaqMan Human MicroRNA Assay Set v2.0 (Applied Biosystems) é limitante com relação à identificação de novos transcritos não codificadores, uma vez que esse kit contém iniciadores para 377 miRNAs específicos, e segundo dados atuais do miRBase (Release 20, acessado em 21/11/2013 e disponível em http://www.mirbase.org) já foram identificados 1.872 miRNAs para Homo sapiens. Mesmo com essa limitação, a técnica é bem aceita em literatura e utilizada em inúmeros estudos (de Melo Maia et al. , 2013; Dmitriev et al. ,2013; Martinez-Pacheco et al. , 2014; McDonald et al. , 2013; Zhang et al. , 2013a). 
Com relação à meta-análise, a grande quantidade de informação constantemente publicada por pesquisas biológicas e médicas e disponíveis em bancos de dados públicos (TCGA, NCBIGEO e ArrayExpress) tem levado diversos grupos a combinarem conjuntos de informações em busca de respostas mais precisas e abrangentes (Walker et al. , 2008). Pesquisas no PubMed com a palavra meta-analysis no campo de título resultou em 29.488 artigos até o presente momento (pesquisa realizada na data de 27-12-2013). Porém, segundo descreve Naylor (1997), metaanálises podem gerar resultados enganosos, ignorando a heterogeneidade significativa entre os estudos, consolidando o viés em estudos individuais e introduzindo novas tendências com a seleção de resultados a serem agrupados. Durante o processo de revisão sistemática para meta-análise, várias decisões devem ocorrer para a inclusão de um estudo, como por exemplo, a avaliação da qualidade e processamento de dados. Cada uma dessas decisões podem incluir componentes subjetivos e objetivos que introduzem a oportunidade para erros aleatórios. A utilização de testes estatísticos para medir o grau de concordância entre os estudos pode ser um mecanismo eficiente para minimizar possíveis erros.

Uma das vantagens da meta-análise é o aumento da precisão com relação aos valores identificados para um determinado gene. Isso acontece devido ao aumento do tamanho do conjunto de dados utilizado e controle da variação entre os estudos, superando alguns problemas decorrentes de estudos individuais e baixa quantidade amostral, sem a validação em estudos independentes. Aqui, a falta de dados moleculares sobre carcinoma de pênis levou a utilização de dados de carcinomas de células escamosas, com a ideia de que o comportamento dos genes no mesmo tipo de epitélio possa ser parecido.

\section{Estudo da Integração de Dados em CaPe}

Estudos envolvendo alterações genéticas em CaPe são extremamente limitados, principalmente devido a raridade da doença e consequente dificuldade de amostras disponíveis, o que torna ainda mais importante o desenvolvimento de uma metodologia para integração de genes potencialmente envolvidos com o desenvolvimento dessa doença. Dados não processados de expressão gênica e de CNAs (ambos obtidos do estudo de Busso (2012)), de alterações epigenéticas e da expressão de miRNAs (ambos obtidos do estudo de Kuasne et al. (2013)), foram utilizados para aplicar a metodologia aqui desenvolvida.

Foram identificados 17 genes candidatos a drivers, dos quais três estão mapeados no cromossomo 7 (CAV1, DTX2 e TWIST1), dois no cromossomo 1 (NRAS e RUNX3), dois no cromossomo 3 ( TNFSF10 e PPARG), dois no cromossomo 8 (DLC1 e SOX17), dois no cromossomo 11 ( $P L C B 3$ e FLI1), um no cromossomo 4 (MSX1), um no cromossomo 6 (NRN1), um no cromossomo 13 (RB1), um no cromossomo 15 (PML), um no cromossomo 17 (BIRC5) e um no cromossomo 19 (DNMT1). Segundo estudos de Pycha et al. (1998), alterações genômicas nos cromossomos 7 e 17 foram identificados com alta frequência em carcinomas de células escamosas de bexiga em um estudo com 220 pacientes. Já no estudo de Martin et al. (2008) avaliando 31 amostras de carcinoma oral de células escamosas foram identificadas alterações estruturais nos cromossomos 3, 7 e 8. Brunelli et al. (2012), utilizando um conjunto de 40 carcinomas de células escamosas de pulmão relataram uma amplificação em 3q pela técnica de aCGH e FISH. Esses estudos sugerem que alterações envolvendo 3q, 7p e 7q e 8q são frequentemente relatados em carcinomas de células escamosas e podem ter um papel relevante nestes tumores. 
Especificamente no cromossomo 3, a alta prevalência de alterações é recorrente em carcinomas de células escamosas, frequentemente englobando grandes regiões de perdas em $3 p$ e ganhos em 3q. Considerando as alterações genômicas, esse perfil foi detectado no presente estudo em $20 \%$ dos casos para 3p23-p22 e 3q25-q26 e mostra-se extremamente frequente em carcinomas de células escamosas de cabeça e pescoço, cervical, pulmão, anus e nasofaringe (Heselmeyer et al. , 1996, 1997; Redon et al. , 2001; Weber et al. , 1998). Além disso, perdas em 3p têm sido descritas por Heselmeyer et al. (1996) e Heselmeyer et al. (1997) como um evento precoce na carcinogênese.

Perdas em 3p e ganhos em 3q são eventos que se repetem em muitos tumores humanos. A presença de sítios frágeis (SF) mapeados nessas regiões poderia ser uma explicação para esse achado. Baseado no relato de Lukusa e Fryns (2008), foram encontrados quatro SFs presentes no cromossomo 3: FRA3A (3p24.2), FRA3B (3p14.2), FRA3C (3q27) e FRA3D (3q25). Em uma comparação entre as duas regiões genômicas com alterações no cromossomo 3 descritas no presente estudo e sítios frágeis não foi observada sobreposição. Assim, é possível que outros mecanismos estejam envolvidos na gênese destes rearranjos.

A presença de perdas em extensas regiões de 3p e ganhos em 3q levou Redon et al. (2001) a avaliarem três linhagens celulares de cabeça em pescoço quanto aos efeitos citogenéticos destas alterações. Os autores relataram a presença de isocromossomo $3 \mathrm{q}$ em todas as linhagens avaliadas, o que sugere que a alteração é frequente ao menos em CEC de cabeça e pescoço. Os autores também sugeriram que a alta frequência de ganhos em 3q em CEC de cabeça e pescoço está relacionada a alterações no gene ATR (3q22-24), podendo resultar na iniciação ou progressão tumoral pela promoção de instabilidade cromossômica devido à resposta aberrante aos danos no DNA (Gollin , 2005; Smith et al. , 1998).

Os 17 candidatos a drivers foram associados com módulos enriquecidos para o ciclo celular (módulos 1, 2 e 19) e regulação da transcrição (módulos 0, 14, 15, 23 e 35). Foi encontrada uma frequência média de seis passengers por módulo, formado em média por 24 genes. A alteração no equilíbrio entre o ciclo celular e vias como a apoptose (relacionada com os genes candidatos RUNX3 e NRAS) é um evento chave para o desenvolvimento tumoral, que também ocorre devido à desregulação dos níveis de expressão de oncogenes e supressores tumorais responsáveis pela regulação da transcrição e podem ser responsáveis pelo surgimento de metástases, incluindo invasão local, disseminação e colonização de órgãos distantes (Ell e Kang , 2013). No presente trabalho foram identificados os fatores de transcrição $P M L, R B 1, R U N X 3$ e SOX17 com função de genes supressores tumorais.

Nenhum supressor tumoral encontrado apresentou deleção homozigótica, porém alterações significativas por metilação foram identificadas em 14 genes, sendo oito hipometilados ( $R B 1$, TNFSF10, PLCB3, BIRC5, DNMT1, NRAS, RUNX3 e DTX2) e seis genes hipermetilados (CAV1, PML, MSX1, NRN1, TWIST1 e SOX17). Dos 17 genes candidatos a drivers, 10 foram preditos como alvos de 17 miRNAs, sendo nove exclusivos. Quatro genes foram identificados com expressão aumentada regulada pelos miRNAs hsa-miR-130b, hsa-miR-182, hsa-miR-20a e hsamiR-429 e seis foram relacionados com miRNAs identificados com expressão diminuída (hsa-let7c, hsa-miR-134, hsa-miR-139-5p, hsa-miR-145 e hsa-miR-484), sendo o hsa-let-7c aquele com maior frequência (4/17), seguido pelo hsa-miR-130b (3/17). No genoma humano alguns miRNAs aparecem agrupados em clusters e tendem a ser co-expressos e participar de vários processos fisiológicos e patológicos (Xie et al. , 2013). Em buscas nos banco de dados miRBase (disponível 
em http://www.mirbase.org) e miRGen (disponível em http://www.diana.pcbi.upenn.edu/) foi avaliado se os miRNAs identificados no presente estudo formavam algum cluster. Apesar dessa hipótese não ter sido confirmada, todos os miRNAs encontrados (menos o hsa-miR-320) já foram descritos na literatura com alguma participação em clusters. É importante destacar que seis genes foram identificados como alvos de múltiplos miRNAs, como é o caso do FLI1 (hsa-miR-130b e hsa-miR-429), DLC1 (hsa-miR-130b, hsa-miR-20a e hsa-miR-429), PPARG (hsa-miR-130b e hsa-miR-20a), RUNX3 (hsa-miR-145 e hsa-miR-484), NRAS (hsa-let-7c e hsa-miR-145) e TNFSF10 (hsa-let-7c e hsa-miR-139-5p).

Em câncer de pênis não há relatos na literatura sobre a influência de miRNA como mecanismo de alteração da expressão de transcritos codificadores. Entretanto alguns miRNAs aqui identificados já foram descritos em outros estudos, como em Zeng et al. (2012) que relataram um miRNA circulantes (hsa-miR-20) com altos níveis de expressão no soro sanguíneo de 20 pacientes com carcinoma de nasofaringe. Esse miRNA participa de um cluster formado pelos miRNAs hsa-miR-92a-1, hsa-miR-18a, hsa-miR-17, hsa-miR-19b-1 e hsa-miR-19a. Com relação ao hsa-miR-429, estudos de Li et al. (2013) identificaram expressão aumentada em pacientes com carcinoma colorretal (CRC) e associação com tamanho tumoral, linfonodo, metástase e pior prognóstico. A expressão aumentada desse miRNA inibe a apoptose por agir diretamente sobre SOX2, sugerindo um papel oncogênico em CRC.

No presente estudo, os miRNAs hsa-miR-429, hsa-miR-20a e hsa-miR-130b foram identificados com níveis de expressão aumentados e como possíveis reguladores do gene $D L C 1$, que apresentou expressão diminuída do transcrito e deleção hemizigótica. Estudos com o gene $D L C 1$, candidato a driver mapeado em 8p22-p21.3, mostram que mutações na região codificadora desse gene são raras em tumores humanos, enquanto deleções homozigóticas e hemizigóticas tem sido frequentemente relatada em tumores sólidos como fígado, pulmão, cólon e mama. Nesses tumores a incidência de deleções hemizigóticas do $D L C 1$ é maior do que deleções em genes supressores tumorais como INF4/ARF, PTEN ou TP53 (Xue et al. , 2013). Mecanismos epigenéticos são predominantemente responsáveis pela expressão diminuída e silenciamento do $D L C 1$ em tumores humanos e, em particular, em doenças hematológicas. O gene $D L C 1$ não se encontra metilado na medula óssea normal e linfócitos, mas foi detectada a hipermetilação da região promotora desse gene em mais de $80 \%$ dos pacientes com leucemia mielóide linfoblástica e linfoma não-Hodgkins (Pike et al. , 2008; Shi et al., 2007; Taylor et al., 2007; Ying et al., 2007). Em outras doenças hematológicas, o $D L C 1$ foi encontrado com hipermetilação em $78 \%$ dos pacientes com mielomas múltiplos (MM) e em 6/9 linhagens celulares de MM (Song et al. , 2006; Xu et al. , 2008).

A função do $D L C 1$ está relacionada com adesão focal, regulação da migração e proliferação celular. Também é responsável por codificar um membro da família rhoGAP, que desempenha um papel na regulação de pequenas proteínas GTPs. A família GAP participa de vias de sinalização responsáveis pelo controle de alterações no citoesqueleto. Liao e Lo (2008) relataram a inativação deste gene em carcinomas hepatocelulares, bem como no carcinoma de nasofaringe, próstata, rim, útero, ovário e gástrico. Em camundongos, o ortólogo é responsável por etapas da embriogênese como formação do tubo neural, cérebro, coração e placenta, assim como descrito por Durkin et al. (2005). Yang et al. (2013) associaram baixos níveis da expressão desse gene com carcinomas de células escamosas devido a perda de função para regulação da proliferação, invasão, ciclo celular e apoptose. Baixos níveis de expressão desse gene também foram relatados 
por Tripathi et al. (2013) em 214 casos de carcinomas de células escamosas de cavidade oral. No estudo sobre o carcinoma de pênis, não foram encontrados níveis alterados de metilação no gene $D L C 1$. Mesmo assim, a expressão diminuída identificada para esse gene pode ser resultante da inativação de um dos alelos (ou ambos), bem descrita na literatura em tumores sólidos, e/ou ação de miRNAs. Aqui, os miRNAs hsa-miR-130b, hsa-miR-20a e hsa-miR-429 foram identificados com expressão aumentada, e preditos como reguladores do $D L C 1$.A atuação desse duplo mecanismo de controle da expressão pode ser responsável pelo silenciamento do gene, resultando em baixos níveis de transcritos codificadores em amostras tumorais quando comparadas com amostras normais. Com relação ao $h s a-m i R-130 b$, os resultados obtidos no estudo com carcinoma de pênis foram concordantes com aqueles publicados por Haoran2013 em carcinoma hepatocelular que associaram o hsa-miR-130b com o crescimento de células tronco tumorais, responsáveis por pior prognóstico e recorrência frequente. A expressão aumentada desse miRNA ocorre em paralelo com a redução da expressão do TP53INP1, um alvo conhecido desse miRNA e relacionado com processo apoptótico e controle do ciclo celular. Ainda segundo os autores, células transfectadas com hsa-miR-130b apresentam alta resistência a agentes quimioterápicos.

O gene candidato a driver, PPARG/NR1C3, mapeado em 3p25 é um receptor nuclear responsável pela regulação do metabolismo lipídico. Takashima et al. (2005) relataram que o aumento de expressão de PPARG inibia células do adenocarcinoma de Barrett ao induzir a parada do ciclo na fase G1 e apoptose. Porém, em estudos epigenéticos de Zhao et al. (2013a) foi mostrado que a metilação da região promotora do $P P A R G$ e a expressão diminuída do transcrito estavam associadas com altos níveis de inflamação em casos de hepatite viral crônica B. Jung et al. (2005) identificaram que a expressão diminuída desse gene em carcinoma cervical levou à inibição do crescimento celular. Silveira et al. (2009) relataram deleções nos genes PPARG e TP53 em pacientes com síndrome mielodisplásica (SMD), sugerindo esses genes como candidatos a marcadores moleculares. Colangelo et al. (15) associaram o hsa-miR-130b com pior prognóstico em pacientes com câncer colorretal. Nesse mesmo estudo, em experimentos in vivo e in vitro, o gene PPARG foi identificado como alvo direto desse miRNA em CRC. A expressão variável de $P P A R G$ esteve diretamente relacionada com o nível de expressão do hsa-miR-130b, ressaltando sua importância biológica. Assim segundo o estudo, algumas evidências indicam que a maioria dos efeitos no hsa-miR-130b são dependentes da supressão de PPARG, que por sua vez desregula a via do PTEN, E-caderina, Snail e do $V E G F$, mediadores diretos da proliferação celular, transição epitélio-mesênquima (EMT) e angiogênese.

Segundo Wahli e Michalik (2012), a perda do mecanismo de controle da resposta inflamatória pode levar ao desenvolvimento de doenças crônicas caracterizadas pela produção excessiva de ácido araquidônico, citocinas inflamatórias e moléculas de adesão. A ativação do PPARG é relacionada com o processo anti-inflamatório devido a inibição da produção de citocinas. O presente estudo deu evidências de que dois mecanismos diferentes podem contribuir para a diminuição da expressão desse gene (perda da sequência do gene e regulação pelo hsa-miR-130b), sugerindo que essa alteração pode levar ao aumento da inflamação, que em excesso causa danos genéticos devido à produção de componentes oxidantes. Segundo Ziech et al. (2011), a presença de espécies reativas de oxigênio (ROS) no processo inflamatório também foi associada com danos epigenéticos. Kundu e Surh (2012) descrevem que a inflamação também atua como supressora da atividade de reparo a danos no DNA, o que poderia contribuir para o desenvolvimento do câncer 
de pênis. O quimioterápico CS-7017, um agonista de PPARG, é descrito por induzir alterações morfológicas e diferenciação celular, bem como efeito anti-proliferativo. A fase II desse clinical trial em combinação com o EGFR tem sido utilizado para o tratamento de pacientes com carcinoma de pulmão. Estudos em linhagens celulares mostraram o CS-7017 como altamente seletivo para PPARG em comparação com outros genes da família PPAR, sendo utilizado na inibição da proliferação em carcinoma de tireóide e do pâncreas (Shimazaki et al., 2008). Semelhante aos estudos citados, em CaPe foi identificado o hsa-miR-130b com expressão aumentada e o gene $P P A R G$ com expressão diminuída, indicando que a deteç̧ão desse miRNA e sua associação com $P P A R G$ podem estar relacionados com etapas importantes do desenvolvimento do carcinoma de pênis.

O gene TNFSF10, identificado aqui com seis genes passengers em seu módulo e enriquecidos para processos celulares, codifica uma proteína conhecida como TRAIL que é capaz de induzir a apoptose em uma variedade de tumores (He et al. , 2012). Em humanos, essa atividade ocorre pela ligação de TRAIL a dois receptores apoptóticos, TRAIL-R1 e TRAIL-R2, resultando no recrutamento e iniciação da cascata de caspases (Sheridan et al. , 1997; Walczak et al. , 1997). Em linhagens celulares de células escamosas, Loebinger et al. (2010) mostraram que células tronco mesenquimais com expressão aumentada de TRAIL migraram para o tumor e reduziram o crescimento de células primárias e metastáticas de câncer. Apesar da sua capacidade apoptótica, estudos recentes de Kaminskyy et al. (2013) mostraram que a expressão aumentada desse gene pode promover invasão e metástase em células tumorais resistentes a TRAIL. No presente estudo foi observado ganho de cópias genômicas e expressão aumentada do gene TNFSF10. Além disso, esse gene foi predito como alvo do miRNA hsa-let- $7 c$, identificado com expressão diminuída. Semelhante aos resultados obtidos no presente estudo com relação ao hsa-let- $7 c$, a expressão diminuída desse miRNA foi descrita em leucemia mielóide aguda (Pelosi et al. , 2013), leucemia promielocítica aguda (Careccia et al. , 2009), carcinomas de pulmão (Zhao et al. , 2013b) e próstata (Nadiminty et al. , 2012). Em 2013, Zhao et al. (2013b) associaram a expressão diminuída de miRNAs e aumento da proteína TRAIL em carcinomas de bexiga. Para isso, foram criados elementos de resposta (MRE, do inglês miRNA response elements) aos hsa-miR-1, hsa-miR-133 e hsa-miR-218 para conferir a expressão da TRAIL. Em seguida, foi construído um adenovírus recombinante de TRAIL, regulado pelos MREs chamado de Ad-TRAIL-MRE-1-133-218, infectando tecido normal e tumoral. A expressão desse recombinante foi detectada pelas técnicas de qPCR, immunoblot e ELISA confirmando que a infecção por Ad-TRAIL-MRE-1-133-218 resultava na expressão de TRAIL. No tecido normal, também infectado, não foram detectados níveis de expressão dessa proteína. Com relação ao estudo sobre carcinoma de pênis, esses miRNAs não foram identificados. Entretanto, o hsa-let- $7 c$ apresentou expressão diminuída e aparece como possível regulador de TNSFS10 (observado em buscas pelos bancos de dados de predição de miRNA). Além disso, esse gene foi identificado com perda de metilação na região promotora, reforçando outro possível mecanismo responsável pela expressão aumentada de TNFSF10. Estudos futuros com TRAIL em CaPe podem confirmar se essa citocina pode atuar como um agente anti-tumoral, possibilitando o desenvolvimento de novas estratégias terapêuticas para estes tumores.

O gene supressor tumoral $P M L$, localizado na região 15q22, tem a capacidade de bloquear a proliferação celular e induzir apoptose em combinação com outros genes, participando de vias 
como do TP53, TGF- $\beta$, TNF- $\alpha / N F-k a p p a \beta$ e mTOR. Singh et al. (2013) identificaram expressão diminuída desse gene em carcinoma cervical uterino em $68 \%$ dos casos (89/130) infectados por HPV dos tipos 16 e 18. Esse gene também foi encontrado com expressão diminuída em 25/132 casos de carcinomas de células escamosas de esôfago (Yen et al. , 2011). No presente estudo, o gene $P M L$ também foi identificado com expressão diminuída em 13/31 amostras de carcinomas de pênis infectados pelo vírus (HPV16 e 18). Kyoko e Keisuke (2013) relataram uma associação entre células troncos hematopoiéticas (HSC, do inglês Hematopoietic stem cells) e o gene $P M L$. A proteína codificada por este gene é responsável por funções importantes no desenvolvimento tumoral, como por exemplo, atividade de sumoilação, fosforilação e acetilação. Deleção do gene $P M L$ direciona a perda de quiescência das HSCs, resultando em proliferação alterada e subsequente senescência celular. Em revisão de Yang e Wang (2011) foi apresentado que 65 regiões promotoras de miRNAs contém um sítio de predição para $P M L-R A R A$ (fusão ocorrida por translocação). Saumet et al. (2008) relacionaram a repressão transcricional do hsa-miR-182, pelo oncogene $P M L-R A R A$ após tratamento com ácido retinóico. Este mecanismo atua na regulação de vias importantes da leucemia promielocítica aguda, como a adesão celular e proteínas HOX, cuja expressão é diminuída por ação quimioterápica. Em carcinoma de pênis esse mecanismo regulador não foi identificado, o que pode ser resultado do critério de seleção de miRNAs utilizado no estudo, das limitações da plataforma ou então devido a ação tecido específico do miRNA. Apesar disso, altos níveis de metilação foram identificados na região promotora do gene $P M L$, possivelmente contribuindo com a expressão diminuída identificada para esse gene. Estudo de Croce et al. (2002) revelaram que a fusão PML-RARA se liga a região promotora do gene RARB2 (receptor de ácido retinóico, conhecido pela sua atividade supressora no tumor), induzindo o silenciamento transcricional. Quimioterápicos envolvendo ácido retinóico são utilizados em pacientes com câncer de pulmão de alto risco para reativar o $R A R B$ 2. Embora esse gene esteja associado com atividade supressora do tumor, sua expressão foi relacionada com pior prognóstico em pacientes com carcinoma de pulmão de células não pequenas (Khuri et al. , 2000). Estudos de Pappas et al. (2011), também com esse tipo de carcinoma, avaliaram que a expressão do RARB2 é necessária para o crescimento e manutenção do fenótipo oncogênico em células onde esse gene não foi inativado, demonstrando o seu papel duplo em vias relacionadas com o câncer. No presente estudo, a expressão diminuída do gene $P M L$, possivelmente relacionada com perda de segmento e altos níveis de metilação, pode ser responsável pela ativação da expressão do gene RARB2 em carcinoma de pênis, sugerindo seu papel oncogênico nessa doença. Com relação a uma possível associação entre $P M L$ e HPV, o presente estudo não identificou esse gene como diferencialmente expresso quando comparadas amostras positivas e negativas para infecção pelo vírus.

O gene TWIST1 foi descrito como uma proteína supressora da expressão de E-caderina, ligada também ao controle da embriogênese. A expressão aumentada do TWIST1 é capaz de induzir a transição epitélio-mesênquima (EMT) e se correlaciona com doença metastática em carcinoma de várias origens (Yang et al. , 2004). A ruptura da membrana basal e da camada de células mioepiteliais é um sinal precoce da formação de um clone de células responsáveis pelo processo de invasão. Para infiltrar o estroma e ter acesso aos vasos linfáticos e sanguíneos, as células epiteliais malignas devem desativar o mecanismo de adesão célula-célula e adquirir propriedades locomotoras. Este mecanismo celular é denominado de EMT (Mathias et al. , 2013). No câncer de 
pâncreas, Sen-Yo et al. (2012) relataram que o gene TWIST1 apresentava expressão diminuída devido a alta frequência de metilação $\left(66.7 \%, p=4 \times 10^{-4}\right)$. Okada et al. (2010) também encontraram o gene TWIST1 metilado em um estudo com 189 pacientes com câncer colorretal. Em um estudo com 28 amostras de carcinomas cervicais, Missaoui et al. (2011), relataram hipermetilação da região promotora do gene TWIST1 em 50\% dos casos, além de alterações na via CDKN2A e altos níveis de metilação desse gene, destacando a influência epigenética no controle do ciclo celular pró-tumor. Segundo os autores, a metilação aberrante do TWIST1 é um evento inicial da carcinogênese e pode servir como um marcador molecular adicional para diagnóstico precoce. Estudos de Cho et al. (2012) mostraram que pacientes com câncer de mama que apresentaram metilação da região promotora do TWIST1 tinham uma taxa de mortalidade pela doença maior que pacientes que não apresentavam metilação. No presente estudo, esse gene não foi associado com pior prognóstico, mas várias sondas na região promotora do gene TWIST1 apresentaram enriquecimento significativo e a hipermetilação foi confirmada pela técnica de pirosequenciamento. Altos níveis de metilação da região promotora e a presença desse gene em uma região com perda de segmento são mecanismos concordantes com expressão diminuída identificada, sugerindo seu papel como um importante biomarcador em carcinomas de pênis.

Os genes da família SOX estão envolvidos na determinação do sexo e diferenciação celular. Genes que codificam as proteínas dessa família, com domínios característicos de fatores de transcrição, são expressos numa variedade de tecidos em desenvolvimento (Bowles et al. , 2000; Xia et al. , 2000). No presente estudo, os níveis de metilação de SOX17 apresentaram correlação inversa significativa com os níveis de expressão, indicando a importância da metilação na regulação da expressão gênica. SOX17 tem sido relatado como um antagonista importante e um inibidor da via canônica de sinalização WNT pela degradação da beta catenina (Jia et al. , 2010; Liu et al. , 2007). Além disso, alterações nos padrões de metilação de SOX17 foram relatadas como tendo um papel fundamental em diversos tumores humanos, incluindo carcinoma colorretal (Zhang et al. , 2008), do pulmão (Yin et al. , 2012), de mama (Fu et al. , 2010) e hepatocelular (Jia et al. , 2010). Semelhante aos nossos resultados, a expressão de SOX17 foi inversamente correlacionada com a hipermetilação do promotor em linhagens celulares de câncer da tireóide (Li et al. ,2012a). Oishi et al. (2012) demonstraram que a hipermetilação do gene SOX17 pode ser útil como aplicação de diagnóstico molecular para a detecção precoce de recidiva em pacientes com carcinoma gástrico. Outro mecanismo de inativação alélica desse gene é por ação de miRNAs. Colas et al. (2012) relataram que a regulação pelos miRNAs hsa-let-7c e hsa-miR-18 diminui a expressão de genes do endoderma (SOX1\%, CER1, FOXA2 e CLDN6) durante a formação da camada germinativa na embriogênese. Apesar do miRNA hsa-let- $/ c$ ter sido identificado como diferencialmente expresso no estudo de câncer de pênis, ele não foi predito como regulador do gene SOX17. Em carcinomas de células escamosas do esôfago, Jia et al. (2012) identificaram que a inativação do $S O X 17$ pela regulação do $h s a-m i R-141$ e metilação da região promotora eram responsáveis pela ativação da via de sinalização do $W N T$, contribuindo para migração e proliferação celular. Yang e Chang (2013) relataram que a expressão aumentada do gene SOX17 em camundongos estava associada ao aumento da angiogênese e desestabilização da vascularização tumoral, persistindo durante o crescimento do tumor. Os estudos apresentados sugerem que a inibição do $S O X 17$ é diretamente relacionada com a ativação da via de sinalização do $W N T$. Entretanto, se a ativação do WNT em estágios precoces do câncer gastrointestinal induz a ex- 
pressão de SOX17, em estágios avançados esse gene é inibido epigeneticamente, por metilação (Du et al. , 2009). Em seu estudo, Du et al. (2009) sugerem ainda que a expressão aumentada de SOX17 funcione como uma proteção para os tumores benignos de progressão maligna em um estágio inicial de desenvolvimento de neoplasias, e a expressão diminuída de $S O X 17$ contribui com a progressão maligna, pela ativação da via $W N T$. É possível que essa atividade, via $W N T$, seja um dos mecanismos de ação do $S O X 17$ em alguns tipos de carcinomas, incluindo o de pênis.

A via $C D K N 2 A / p 16-C D K 4 / 6-R B$ é responsável pelo controle do ciclo celular e alterações nos genes dessa via são bem descritas em literatura devido a sua influência no desenvolvimento tumoral. Goldhoff et al. (2012) associaram baixos níveis de expressão do gene $R B 1$ com alterações nos genes da via $p 16-C D K 4 / 6-R B 1$ em glioblastoma multiforme. Os autores, por imunoistoquímica, verificaram que $4 / 34$ tumores $(11,8 \%)$ apresentavam perda de expressão para Rb no grupo teste assim como em 5/51 amostras (9,8\%) de GBM independentes. Este achado foi concordante com uma análise complementar utilizando dados obtidos no TCGA, onde 18/170 (10,6\%) tumores também apresentavam perda da expressão de RB1. A metilação desse gene foi relatada por Liu et al. (2012) como um evento comum nos carcinomas gástricos relacionados com o vírus Epstein-Barr (EBV), que pode induzir a metilação do RB1. No presente estudo, esse gene foi identificado com expressão aumentada, baixos níveis de metilação da região promotora, alvo do hsa-let- $7 c$ (identificado com expressão diminuída) e presente em uma região com ganho de segmento. Mesmo que esse gene tenha sido obtido como diferencialmente expresso na comparação entre amostras tumorais e normais, é possível que na presença de infecção pelo HPV, os baixos níveis de metilação de $R B 1$ sejam um mecanismo de proteção celular. O bloqueio da proteína $\mathrm{Rb}$ por oncoproteínas do HPV e a perda de função de Rb por metilação levaria a um aumento no nível de expressão desse gene, que foi perdido devido à infecção viral. Apesar do presente estudo não ter identificado associação entre $R B 1$ e dados clínicos, Zhao et al. (2012) mostraram que a expressão aumentada desse gene em células tumorais de pulmão foi fortemente associada com recorrência.

O candidato a driver, DNMT1 (DNA metiltransferase-1) codifica a enzima metiltransferase 1 , a qual é capaz de acelerar a adição de grupo metil às citosinas adjacentes a guaninas. Qayum e Ashraf (2006) identificaram correlação significativa $(\mathrm{p}<0,001)$ entre a expressão aumentada de DNMT1 e TP53 em pacientes com linfoma, sugerindo que a expressão de TP53 pode ser regulada pela DNMT1. Apesar de não ter sido identificado como um candidato a driver em câncer de pênis, o gene TP53 foi diferencialmente expresso em amostras tumorais. Em linhagens celulares de câncer de pulmão, Tennis et al. (2012) relataram que a expressão aumentada da DNMT1 é capaz de inibir o gene WNTrA (apesar de descrito em literatura com alta taxa de metilação, em CaPe esse gene não foi identificado com alteração significante). Li et al. (2011) também encontraram expressão aumentada da DNMT1 em 47,8\% (21/46) dos pacientes com carcinomas de células escamosas de esôfago. Os autores também relataram aumento da expressão de DNMT3A e DNMT3B, sugerindo uma via regulatória comum entre esses genes. No presente estudo não foi identificada alteração em $D N M T 3 A$ e $D N M T 3 B$, porém, mais de $70 \%$ da região promotora da DNMT1 (mapeada na região 19p13.2) apresentava diminuição dos níveis de metilação em amostras tumorais em comparação com amostras normais. Também foi identificada expressão aumentada do transcrito e amplificação genômica. Essas alterações podem ser responsáveis por uma mudança no perfil de metilação observado em $\mathrm{CaPe}$, uma vez que a 
DNMT1 é responsável pela manutenção do padrão epigenético.

O gene BIRC5 (também chamado de survivina), mapeado em $17 \mathrm{q} 25$, foi relacionado com atividades no ciclo celular e apoptose e identificado com expressão aumentada em diversos tumores como neuroblastoma (Hagenbuchner et al. , 2012) e câncer de pulmão (Vaishlia et al. , 2008). Mutações somáticas exclusivas do gene BIRC5 foram relatadas por Knauer et al. (2013) em carcinomas de cabeça e pescoço que poderiam estar relacionadas com resistência a ao tratamento quimioterápico. No presente estudo, esse gene foi selecionado como candidato a driver, apresentando ganho no número de cópias de DNA, expressão aumentada do transcrito e perda de metilação nas ilhas CpGs. O BIRC5 é responsável por codificar a survivina, uma proteína responsável pela regulação do ciclo celular, apoptose e angiogênese. É o menor membro da família de inibidores de apoptose (IAP), controlando a compactação cromossômica, dinamismo dos microtúbulo e formação do fuso mitótico. Diversos estudos relatam a alteração nos níveis de survivina em carcinomas orais, cutâneos e cervicais (Barbosa et al. , 2011; H.Lu et al. , 2010; Li et al. , 2012b; Lo-Muzio et al. , 2001; Lu et al. , 2012; Su et al. , 2010). A expressão aumentada da survivina também foi relatada por Fraunholz et al. (2012) em carcinoma de ânus e sugerida como um possível marcador para alvo terapêutico. Em 2011, Carrasco et al. (2011) inibiram a expressão de survivina em linhagens de células tumorais de pulmão, próstata, ovário, cervical, pele e cérebro, utilizando um oligonucleotídeo antisense de survivina (LY2181308). Essa inibição induziu a apoptose dependente de caspase 3 e a interrupção do ciclo celular nas fases G2/M. O estudo de Carrasco et al. (2011) mostra que a inibição da expressão de survivina por LY2181308 sensibiliza as células tumorais à apoptose induzida por quimioterápicos. Em outra abordagem, Su et al. (2010) utilizaram pequenos RNAs de interferência (siRNA) para diminuir a expressão da survivina em linhagens celulares de carcinomas orais de células escamosas, onde a interação siRNA-survivina seria responsável por inibir a proliferação celular e induzir apoptose nesse tipo de carcinoma. Em CaPe foi identificada expressão aumentada de BIRC5, concordante com o ganho de cópias genômicas e diminuição dos níveis de metilação do DNA, sugerindo a atividade desse gene no desenvolvimento tumoral e classificando-o como um potencial alvo para testes anti-BIRC5.

O gene $N R A S$, mapeado em 1p13.2, tem função relacionada com resposta imune inata, ativação da via $M A P K K$, coagulação sanguínea, regulação da transmissão sináptica, regulação da proliferação celular e aparece associado a diversas vias como as dos receptores de células B, DAP12, sistema imune, álcool e superfície celular. Em 2012, Hodis et al. (2013) publicaram um estudo mostrando que 100/121 pacientes com melanoma apresentavam mutação para $N R A S$ $(\mathrm{n}=27)$ ou BRAF $(\mathrm{n}=73)$. Aproximadamente $44 \%$ (32/73) dos melanomas com alta frequência de $B R A F$ mutado também apresentavam deleção de PTEN, sendo que esse gene aparecia alterado em $4 \%(1 / 27 \%)$ dos casos de melanoma com alta frequência de NRAS mutado. Ainda segundo Hodis2012, as mutações em BRAF e NRAS são descrita como eventos drivers em melanoma. Yang et al. (2012) descreveram que a proteína GAB2, relacionada com processo inflamatório e angiogênese, é co-expressa com o gene $N R A S$ mutado, favorecendo a metástase em pacientes com melanoma. Em nosso estudo, NRAS foi identificado com altos níveis de transcritos codificadores e diminuição dos níveis de metilação do DNA em amostras tumorais, sugerindo que a expressão aumentada desse gene tenha participação no desenvolvimento tumoral. Além disso, o NRAS foi predito como alvo dos miRNAs hsa-let- $7 c$ e $h s a-m i R-145$, todos aqui identificados com expressão 
diminuída. De fato, baixos níveis de expressão do miRNA hsa-let-7c, mapeado na região 3p21, foram correlacionados com altos níveis de expressão de $N R A S$, em carcinomas de células escamosas de pulmão (Johnson et al. , 2005). É possível que em vias associadas com o desenvolvimento do carcinoma de pênis onde o gene atua, esse mecanismo de regulação por miRNAs apresente atividade semelhante.

A identificação de vias associadas aos candidatos a driver pode ser essencial para determinar um possível caminho que leve ao desenvolvimento de CaPe. Segundo Vogelstein et al. (2013), genes candidatos a drivers estão associados a três grandes processos e 12 vias de sinalização celular são fundamentais para a formação e manutenção tumoral: sobrevivência celular (PI3K, RAS, STAT, MAPK, TGF- $\beta$, ciclo celular e apoptose), desenvolvimento (NOTCH, Hedgehog, $A P C$, modificação da cromatina e regulação da transcrição) e manutenção do genoma (controle a danos do DNA). Observando os candidatos a drivers identificados, é possível destacar que vários deles são bem descritos em literatura por atuar nas vias críticas do processo tumoral, como no caso dos genes CAV1 (vias do TP53, EGFR1 e WNT), NRAS (vias da MAPK, PI3K e $R A S$ ), $P M L$ (vias da $T G F-\beta, T N F-\alpha, N F-k a p p a \beta, m T O R$ e TP53) e $R B 1$ (vias do TP53, E2F e FAZ). Cesare et al. (2013) descreveram a via do p53, como uma via essencial para a perda de proteção dos telômeros. Quando as células perdem a função do p53, os genes responsáveis ficam impedidos de interromper o ciclo celular na fase G1, um ponto importante no ciclo para o reparo a danos do DNA, ou, se o dano não pode ser reparado, ocorre o direcionamento da célula para a apoptose. A função do TP53 é perdida em células tumorais devido a uma mutação no gene ou a inativação da função da proteína por meio da infecção por vírus relacionados ao desenvolvimento de carcinomas, como por exemplo, HPV (Papilomavirus Humano), HMTV (vírus do tumor mamário humano), JCV (vírus John Cunningham), SV40 (Simian virus 40), EBV (Epstein-Barr vírus) e HCMV (citomegalovirus humano). Células com ausência de função da proteína p53 são capazes de continuar o processo de divisão sem proteção dos telômeros, causando instabilidade genômica, que é uma característica comum de células malignas. Outras vias como TGF- $\beta$ (que participa do desenvolvimento e progressão tumoral), NOTCH (possível via responsável pela sobrevivência tumoral), NF-kappaB (diretamente relacionada com processos inflamatórios durante a formação de tumores) e WNT (relacionada com células tronco tumorais), também são vias de sinalização muito características do câncer (Capaccione e Pine , 2013; Hoesel e Schmid , 2013; Holland et al. , 2013; Lee et al. , 2013).

Em um estudo sobre os efeitos toxicológicos relacionados aos candidatos a drivers foi utilizado o banco de dados Comparative Toxicogenomics (disponível em http://ctdbase.org/), que armazena dados da literatura descrevendo 124.000 compostos químicos, 2,6 milhões de genes e proteínas e associação com o Gene Ontology e KEGG além de 6.300 doenças humanas. Os genes $R B 1, P P A R G, N R A S$ e $C A V 1$, aqui descritos como candidatos a drivers, foram associados com vias de sinalização importantes como TP53, TGF, PPAR/RXR, NF-kappaB, RAR e TR/RXR, todas já descritas na literatura pelo envolvimento em doenças como o câncer (Altucci et al. , 2007; Hoesel e Schmid , 2013; Kalra e Bapat , 2013; Maire et al. , 2012). Foi utilizado o banco de dados DGIdb (disponível em http://dgidb.genome.wustl.edu/) para a busca de possíveis agentes terapêuticos para os candidatos a driver selecionados. Doze genes não foram identificados como alvo direto de nenhum quimioterápico aprovado (CAV1, DTX2, FLI1, MSX1, DLC1, TNFSF10, NRAS, NRN1, PLCB3, RUNX3, SOX17 e TWIST1). Com relação aos outros cinco candidatos, 
o gene PPARG foi associado como alvo de 54 drogas (que atuam como agonistas, em sua maioria), seguido pelos genes $D N M T 1$ (7 interações com drogas), BIRC5 (6 interações com drogas), $P M L$ (2 interações com drogas) e RB1 (2 interações com drogas). O gene PPARG já foi descrito em diversos estudos como alvo de drogas para doenças como câncer, diabetes e inflamação intestinal (Byrav et al. , 2013; Dicitore et al. , 2013; Liu et al. , 2013). Kumar et al. (2013) avaliaram o uso de nanopartículas (PEG-b-p(CB-co-LA)) inibidoras de HedgeHog (Hh) e agonistas de PPARG no tratamento de fibrose hepática. Devido à baixa solubilidade em água dessas drogas, as nanopartículas seriam responsáveis por carregar rosiglitazone (RSG), uma droga agonista de PPARG, e vismodgib (GDC), inibidora de Hh até o alvo em pacientes com essa doença. Segundo Davis et al. (2008), esse tipo de análise possibilita o estudo das funções biológicas e redes moleculares que são afetadas pela exposição a compostos químicos, incluindo a resposta ao estresse, apoptose, ciclo celular e vias de sinalização de proteínas específicas. Devido à quantidade limitada de informações disponíveis sobre o câncer de pênis, a integração de genes candidatos a drivers com alvos terapêuticos, vias citotóxicas e suscetíveis aos efeitos toxicogenômicos pode auxiliar na escolha de futuros alvos para estudos funcionais e que possam ser utilizados para o tratamento destes tumores.

Outra abordagem apresentada nesse estudo foi a predição estatística de possíveis reguladores dos genes candidatos a driver. Foi observada uma associação entre os miRNAs hsa-miR-133a, hsa-miR-199a e hsa-let-7a com os genes DNMT1, PPARG, RB1, CAV1, DLC1, RUNX3, DTX2 e NRAS $\left(p<5 \times 10^{-4}\right)$. Nenhum desses miRNAs foi identificado no estudo do carcinoma de pênis. Porém, a predição de possíveis reguladores sugere novos mecanismos de controle da expressão de genes importantes que possam levar ao desenvolvimento e adaptação tumoral. Além dos miRNAs, o gene IL6 mapeado em 7p21, foi predito como regulador dos candidatos DNMT1, FLI1, MET, NRAS, PPARG, RB1, e TWIST1. Essa regulação poderia ser estabelecida pela interleucina através de um controle de vias relacionadas com os genes apresentados. Alterações na expressão da interleucina 6 foram descritas por Ataie-Kachoie et al. (2013) como responsáveis por processos inflamatórios crônicos, possivelmente associados com o câncer. É possível destacar outros reguladores importantes como TP53, HRAS e JUN, todos amplamente descritos em estudos sobre o câncer e mais especificamente, carcinomas de células escamosas (Braakhuis et al. , 2013; Hah et al. , 2013; Pickering et al. , 2013).

Outra abordagem utilizada para avaliar as características dos 17 genes selecionados como candidatos a drivers foi o estudo de medidas de centralidade de rede, aplicadas com sucesso em outros domínios biológicos, como no estudo de Jeong et al. (2001) que estudaram a rede de interação proteína-proteína de levedura a fim de prever mutações letais. Foi demonstrado que a rede é tolerante a erros aleatórios, mas os erros relacionados com as proteínas centrais (em termos de grau) causam letalidade. Da mesma forma, Joy et al. (2005) e Hahn e Kern (2005) descobriram que existe uma associação entre a centralidade de intermediação (do inglês, betweenness centrality) e a essencialidade de um gene (um gene é essencial quando o organismo morre devido ao seu mal funcionamento). Goh et al. (2007) demonstraram que os genes centrais baseados em grau de conectividade também são essenciais. Medidas de centralidade foram originalmente desenvolvidos e utilizados em domínios não biológicos. Por exemplo, o algoritmo PageRank subjacente ao popular site de busca Google é baseado em centralidade de autovetor para classificar as páginas da internet (Pageand et al., 1999). 
Com isso, foi observado que os genes RB1, CAV1, PML, PPARG, DNMT1 e RUNX3 apresentaram os maiores graus de conectividade, todo com mais de 20 interações Como discutido anteriormente, estudos genômicos mostram que a supressão de uma proteína $h u b$ é provavelmente mais letal do que a exclusão de uma proteína não hub. A importância dos genes com alta conectividade é comprovada devido a sua relevância em estudos biológicos. Em buscas no NCBI para o gene $P M L$, foram encontrados 1.117 artigos que apresentam esse gene no campo do título, seguido pelo gene $R B 1$, com 643 estudos, demonstrando a importância de ambos. Destaca-se também que os dois genes com maior conectividade, $R B 1$ e $C A V 1$ apresentaram baixo coeficiente de clusterização. Segundo Joy et al. (2005), a conectividade de um nó (gene), $k$, e os coeficientes de clusterização, avaliam apenas a vizinhança local dos nós da rede (vizinhos mais próximos). Já a medida de centralidade de intermediação (do inglês, betweenness centrality), de um dado nó i em uma rede está relacionada com o número de vezes que o nó é um membro do conjunto de caminhos mínimos que ligam os pares de nós da rede. Assim, essa medida é responsável por influências diretas e indiretas de proteínas em locais distantes da rede e, portanto, permite que se relacione a estrutura de rede local com a topologia global. Em nosso estudo, os genes $R B 1$, $C A V 1$ e $P M L$ apresentaram os maiores valores para essa medida. Os poucos genes altamente conectados no estudo devem ter valores altos para intermediação porque há muitos outros genes exclusivamente e diretamente conectados a eles e o caminho mínimo entre esses genes passa pelos hubs. Entretanto, genes com baixa conectividade apresentam uma variação com relação a valores para intermediação, indicando a presença de genes com alto valor para essa medida e baixa conectividade. Embora a baixa conectividade dessas proteínas implicaria que elas não são importantes, seu alto betweenness sugere que elas podem ter um impacto global. De um ponto de vista topológico, proteínas com essas características estão posicionados para ligar regiões de alta clusterização (contendo hubs), apesar de terem baixa conectividade local.

Com relação à validação, os genes PPARG, CAV1, FLI1 e TNFSF10 foram avalidos pelo método de RT-qPCR e considerados validados devido ao $\mathrm{p}<0,05$. Os resultados obtidos na validação da expressão desses genes são concordantes com outras alterações identificadas, como por exemplo, alterações genômicas, dos níveis de metilação do DNA e de expressão de miRNAs. Os genes SOX17 e TWIST1 foram validados por pirosequenciamento e inversamente correlacionados com a expressão dos transcritos codificadores identificados pela técnica de microarray. Os resultados sugerem os quatro candidatos a driver como alvos em potencial para estudos futuros. Com relação ao gene PML não foi observada diferença significativa no nível de transcritos codificadores entre as amostras tumorais e normais $(p=0,2280)$. Os outros candidatos a drivers não avaliados são potenciais candidatos à validação futura.

O perfil de expressão dos 17 genes candidatos a driver também foram avaliados por validação in sílico através de uma meta-análise com 1.066 amostras obtidas no banco de dados TCGA. Especificamente sobre o carcinoma de pênis, além da falta de um banco de dados com informações sobre genes tecido específicos, há o problema sobre a miscigenação da população brasileira, sugerindo que os dados aqui publicados deveriam ser comparados com um banco de dados de tal população para avaliar o comportamento de genes e suas interações. Na falta dessas informações, foi utilizado o banco de dados TCGA ( The Cancer Genome Atlas, disponível em http://tcga-data.nci.nih.gov) para avaliar a expressão dos 17 genes candidatos a drivers obtidos no estudo. O banco de dados TCGA é um projeto supervisionado pelo NCI (National Cancer 
Institute) e NIH (National Institute of Health) que analisou mais de 8.000 amostras de pacientes com câncer envolvendo 27 diferentes tipos tumorais, com uma estimativa de 100.000 amostras analisadas até 2015. Além das diferentes formas de análise (alteração do número de cópias, expressão de transcritos codificadores, metilação, miRNA e expressão de proteínas) disponibilizadas gratuitamente, essa iniciativa gera uma grande quantidade de dados analisados sob as mesmas condições e com as mesmas plataformas, mantendo um padrão de análise que diminui o viés durante o processamento e interpretação das informações. Na meta-análise proposta foram utilizadas amostras de carcinoma de células escamosas do pulmão, cabeça e pescoço e cervical para avaliar a expressão dos 17 genes candidatos a driver em CaPe.

Foram observados níveis de expressão semelhantes dos genes CAV1, FLI1, NRN1 e PPARG (todos com expressão diminuída) entre amostras de carcinoma de pênis e os três conjuntos amostrais utilizados, reforçando a participação desses genes em vias relacionadas ao carcinoma de células escamosas e como possíveis alvos para estudos posteriores em CaPe. Os genes BIRC5, DNMT1, TNFSF10 (expressão aumentada em CaPe) e DLC1, PML e SOX17 (expressão diminuída em $\mathrm{CaPe}$ ) apresentaram concordância com pelo menos dois conjuntos amostrais (Tabela $13)$.

Contrastando com os resultados anteriores, os genes DTX2, PLCB3, RUNX3 e RB1, todos com expressão aumentada em CaPe, apresentaram resultados opostos aos encontrados na metaanálise. Nesse caso, são necessários mais estudos para avaliar a função desses genes no carcinoma de pênis. É possível que nessa doença eles tenham uma função diferente, onde a expressão aumentada dos candidatos a drivers (reguladores) sejam responsáveis por alterações específicas na expressão de genes dos módulos, levando a formação do tumor.

\section{Estudo da Integração de Dados em HPV}

Em uma revisão publicada por Miralles-Guri et al. (2009) foram avaliados 31 estudos envolvendo a relação entre a infecção pelo HPV e o carcinomas de pênis, entre os anos de 1986 e 2008, constituindo um total de 1.466 amostras do tumor. A somatória de todos os dados obtidos revelou que o vírus foi detectado em cerca de $50 \%$ dos casos, da mesma forma que reportado para câncer de vulva, onde os casos positivos para HPV são de aproximadamente $40 \%$ (Castellsague et al. , 2002). O subtipo prevalente entre os casos positivos para o vírus foi o HPV16 (60,2\% dos casos), assim como demonstrado no presente estudo (41\% de casos HPV+, dos quais, $77 \%$ foram do subtipo HPV16). Especificamente no Brasil, Bezerra et al. (2001), utilizando 82 amostras de $\mathrm{CaPe}$, detectaram a presença do vírus em 30,5\% das amostras pela técnica de PCR. Destes, $50 \%$ apresentaram HPV16, seguido por $16 \%$ dos casos com HPV18 e 8\% HPV6/11. Outro estudo brasileiro relatou a genotipagem do HPV em 80 amostras de CaPe utilizando iniciadores específicos para sequências conservadas dos subtipos 6, 16, 18, 28, 31, 33, 45 e 71 (Kaufman et al. , 2008). Setenta e dois por cento dos casos foram positivos para o HPV, sendo o subtipo 16 o mais frequente $(52 \%)$. No presente estudo foram avaliados 31 casos quanto à infecção pelo HPV pelo kit Linear Array HPV Genotyping Test (Roche), dos quais 32\% foram positivos. As diferentes frequências de ocorrência do vírus entre os estudos podem estar relacionadas a alguns fatores como a aplicação de métodos com sensibilidades distintas para a detecção dos subtipos virais, pequeno número de amostras e avaliação de diferentes subtipos histológicos de CaPe em um mesmo grupo amostral. Sabe-se que CECs (carcinoma epidermoide) de pênis dos subtipos 
basalóide ou condilomatoso possuem maior associação com a presença de HPV de alto risco, o que pode ser observado em 70 a $100 \%$ dos casos avaliados, enquanto tumores verrucosos tendem a ser negativos para o HPV (Cubilla et al. , 1998; Dianzani et al. , 1998; Rubin et al. , 2001; Stankiewicz et al. , 2009). Como apresentado anteriormente, estudos de Rubin et al. (2001) propuseram duas diferentes vias para o desenvolvimento do CaPe: uma relacionada a infecção pelo HPV e outra independente do vírus.

Com o objetivo de investigar a via dependente do vírus, a metodologia de integração de dados também foi utilizada para estudos de genes com alterações diferenciais obtidas da comparação entre amostras positivas e negativas para o HPV. Nessa abordagem, foram utilizadas 31 amostras (13 HPV+/18 HPV-) para as plataformas de aCGH, expressão gênica e metilação. Foram identificados os genes KLK10, PCNA, RFC4 e SOX14 como candidatos a drivers, sendo que de acordo com o estudo de módulos, as vias significativas selecionadas foram àquelas relacionadas com o crescimento e proliferação celular, além de replicação do DNA.

Os quatro genes candidatos a drivers selecionados no estudo apresentaram alterações nos níveis de metilação da região promotora, sendo um gene hipermetilado e três hipometilados. Também foram identificados três genes com ganhos de cópias e um gene com deleção, além de um miRNAs (hsa-miR-154, expressão diminuída) predito como regulador do gene PCNA. A média de interações proteína-proteína (PPI) entre candidatos a drivers e módulos foi de 21,8\% e foram identificados 18 genes passengers nos módulos (média de aproximadamente 5 passengers por módulo). No estudo de Zhu et al. (2014), a expressão do hsa-miR-154 diminuiu significativamente em amostras de tumores primários de próstata em comparação com amostras não-malignas avaliadas por RT-PCR. Ainda segundo os autores, esse miRNA desempenha um papel fundamental na proliferação celular inibindo o gene $C C N D$ 2, cuja função é promover a progressão do ciclo celular através da ativação das CDK4/CDK6 (Sherr , 1994; Weinberg , 1995). O complexo ativado ciclina $D-C D K 4 / C D K 6$ fosforila e inibe a proteína supressora tumoral, $\mathrm{pRb}$, resultando na liberação e aumento dos níveis de expressão do fator de transcrição E2F. Portanto, ciclinas do tipo D são reguladores críticos envolvidos na progressão do ciclo celular da fase G1 para a fase S, o que sugere que elas são proteínas potencialmente oncogênicas. Em tecido de carcinoma de próstata e linhagem celular a proteína $C C N D 1$ é expressa em altos níveis. Em CaPe é possível que esse miRNA tenha função semelhante controlando genes relacionados com as vias do ciclo celular em amostras positivas para infecção pelo HPV.

No estudo de associação entre os efeitos toxicológicos e os 35 genes obtidos na primeira etapa de integração de dados, os genes COL18A1, LDHA, TAF4, DUSP1, SMARCD2, CSNK1D, PCNA, MXD1 e PNKD foram associados com importantes vias de sinalização como TP53, $V D R / R X R, P P A R$ e $R A R$. Myga-Nowak et al. (2011) relataram o ATRA (ácido all-transretinóico) como um potencial quimioterápico devido sua capacidade de regular o crescimento e a proliferação celular. O efeito de ATRA na proliferação celular é mediado por receptores do ácido retinóico (RAR e RXR), que pertencem a uma família de receptores nucleares. A ação de ATRA pode ser inibitória ou ativadora da proliferação dependendo do estado funcional dos receptores. Em linhagens celulares de carcinoma cervical os autores avaliaram a relação entre as proteínas virais E6 e E7 com os receptores de ATRA, e observaram que o ácido all-trans-retinóico não diminui a expressão das proteínas virais, sugerindo que a resposta celular para vitamina $\mathrm{A}$ e outros retinóicos na dieta pode depender do tipo celular e que as células tumorais são resistentes 
a esses retinóicos.

Com relação à via do TP53, Xie et al. (2013) relataram que a inibição da proteína p53 pela proteína viral E6, em carcinoma de células escamosas de cabeça e pescoço, ocorre por dois mecanismos distintos: (1) E6 se associa com E6AP (proteína associada a E6) e degrada a p53 pela via proteossômica e (2) bloqueio de p300 (proteína que permite acetilação da p53, aumentando sua atividade transcricional). A inativação da p53 é um processo crucial para a formação do tumor. Os autores investigaram a relação entre a E6 e p300 para determinar se o bloqueio desta interação poderia restaurar a função da p53. O estudo mostrou que a E6 se liga a p300 em três domínios distintos: CH1, CH3, e C-terminais e se a expressão de CH1 é anormal, a interação entre E6 e p300 é bloqueada, aumentando os níveis totais e acetilados de p53 e sua atividade transcricional. A reativação funcional da p53 também ocorre devido a um aumento da expressão da p21 e dos miRNAs hsa-miR-34a e hsa-miR-200c. Com a utilização do composto CH1iB (responsável por impedir a interação entre a proteína viral e a proteína das células) ocorreu um aumento da atividade da p53 em até $71 \%$. Os autores avaliaram que quando as células foram tratadas com $\mathrm{CH} 1 \mathrm{iB}$, o efeito da cisplastina foi potencializado com relação ao seu efeito antiproliferativo em amostras positivas para infecção pelo HPV16. A interação entre $P C N A$ (essencial para replicação do DNA) e a p53 sugere que, em carcinoma de pênis, estudos funcionais podem revelar uma ação direta no mecanismo de desenvolvimento do tumor em casos positivos para a infecção pelo HPV, semelhante ao que acontece no carcinoma cervical (Branca et al. , 2007) e laringe (Sun et al. , 2012).

Ainda com relação aos 35 genes obtidos na primeira etapa de integração de dados, a predição de possíveis reguladores identificou uma associação entre os miRNAs hsa-let-7a, hsa-miR-4687, hsa-miR-124, hsa-miR-4667, hsa-miR-140, hsa-miR-101 e hsa-miR-326 e genes como DUSP1, PCNA, MXD1, FZD5 e NOTCH1 $\left(p<6 \times 10^{-3}\right)$. Desses, apenas o gene PCNA foi posteriormente identificado como candidato a driver e nenhum dos miRNAs foi identificado em CaPe como diferencialmente expresso. Yamane et al. (2013), relataram que o hsa-miR-124 estava associado com o aumento da proliferação celular por meio da indução do ERK em carcinoma cutâneo de células escamosas. Especificamente em estudos de HPVs, Wilting et al. (2010) identificaram o hsa-miR124 com atividade supressora em carcinoma cervical quando este apresentava altos níveis de metilação. Em queratinócitos imortalizados por HPV (tipos 16 ou 18), níveis elevados de metilação foram associados com a diminuição da expressão do hsa-miR-124, estimulando a migração e proliferação celular. Zhu et al. (2010) descreveram o hsa-miR-101 como regulador do gene MAPK fosfatase-1 (MKP1), responsável pela desativação da via $M A P K$, onde a expressão aumentada desse gene diminui a biossíntese do peptidoglicano de citocinas pro-inflamatórias. A associação entre $M K P 1$ e DUSP1 foi relatada como reguladora da via $M A P K$ em carcinoma de pulmão por Moncho-Amor et al. (2011). Estudos em camundongos knockout para DUSP1/MKP1 confirmaram a inativação da via $M A P K$ por essas fosfatases duais específicas e diversas alterações fisiológicas observadas in vivo, como anormalidade na resposta imune-inata, homeostase metabólica e ativação de células T (Staples et al. , 2011). De acordo com a primeira etapa de integração de dados, os genes DUSP1 e NOTCH1 foram identificados com expressão aumentada e diminuição dos níveis de metilação da região promotora do DNA. É possível que esses genes não tenham sido selecionados como candidatos a driver devido aos critérios estabelecidos na metodologia de integração de dados. Entretanto, como discutido anteriormente, esses genes podem ter papel 
importante no desenvolvimento da doença, como componentes de alguma via adaptativa de ação do vírus na célula.

Especificamente sobre os candidatos a driver, foi identificado o gene KLK10, que pertence a um subgrupo das serinas proteases e tem envolvimento em funções do ciclo celular e proteólise. Em carcinomas de células escamosas foi relatado em estudos como os de Pettus et al. (2009), Vachani et al. (2007), Planque et al. (2006), Worsham et al. (2006) e Dasgupta et al. (2006) e tem sido utilizado como biomarcador para diagnóstico em carcinoma de testículo (Luo et al. , 2001), mama (Dhar et al. , 2001), ductal in situ (Yunes et al. , 2003) e ovário (El-Sherbini et al. , 2011). Esse gene também foi descrito com expressão aumentada em diversos tumores como carcinoma epitelial de ovário (mais estudado), seroso-papilífero, cabeça e pescoço, pulmão e trato gastrointestinal (Santin et al. , 2005; Vachani et al. , 2007). Segundo estudos de El-Sherbini et al. (2011), o KLK10 aparece com expressão aumentada em amostras malignas em comparação com tecido epitelial normal. Devido à presença de KLK10 na circulação sanguínea, o aumento da concentração desse gene em pacientes com carcinoma de ovário é elevado. Altos níveis de KLK10 em tecido tumoral foram associados a estágios avançados da doença e baixa sobrevida. Em particular, níveis séricos pré-operatórios de KLK10 servem como biomarcador para CA125, um marcador tumoral bem estabelecido usado em câncer de ovário. Foi demonstrado que a grande maioria dos tumores negativos para CA125 apresentaram imunomarcação positiva e pacientes negativos para o marcador CA125 apresentaram aumento dos níveis séricos de KLK10. É possível que, em combinação com CA125, o gene KLK10 possa melhorar a sensibilidade do diagnóstico quando comparado apenas com a utilização de CA125. Além desse biomarcador, a eficácia da terapia pode ser monitorada pela quantificação de antígenos de carcinoma de células escamosas no sangue, ou, para os adenocarcinomas, o antígeno carcinoembriogênico (CEA). Atualmente os biomarcadores citológicos mais promissores para HPV de alto risco são imunomarcação para p16(INK4a)/Ki67, metilação da região promotora dos genes CADM1 (molécula 1 de adesão celular) e $M A L$ (proteína associada a maturação de linfócitos T) e integração viral (Litjens et al. , 2013). O comportamento da $K L K 10$ é variante de acordo com a agressividade da lesão cervical, como por exemplo, cervicite, neoplasia intraepitelial cervical de baixo grau, neoplasia intraepitelial cervical de alto grau, carcinoma cervical de células escamosas e até adenocarcinoma, ocorrendo um aumento de expressão.

Ainda sobre a KLK10, Worsham et al. (2006) relataram altos níveis de metilação nesse gene em um estudo com linhagens celulares de carcinoma de células escamosas de cabeça e pescoço (laringe, tecido mole do pescoço, tonsilas e supraglote), onde a expressão diminuída do KLK10 estava associada com a progressão tumoral. Não foi apresentada, entretanto, nenhuma classificação quanto à infecção das amostras pelo HPV. Já Pettus et al. (2009) identificaram expressão aumentada de várias calicreínas ( $K L K$ 5, 7, 8 e 10) em carcinomas orais (língua), e também sugere que esse resultado esteja relacionado com a evolução do tumor. Em um estudo com 47 amostras de carcinomas de pulmão e tecido normal adjacente, Planque et al. (2006) utilizaram uma análise multivariada para correlacionar a expressão aumentada de KLK10 com o tipo histológico do carcinoma $(\mathrm{p}=0,03)$. Esse resultado concorda com um estudo anterior, de Garber et al. (2001), relacionando as calicreínas com regulação do crescimento celular, metástase e invasão. No presente estudo foi identificado ganho de cópias genômicas e hipometilação da região promotora do gene KLK10, concordando com os níveis elevados de transcritos codificadores. É 
interessante a variação entre o aumento e a diminuição de transcritos das calicreínas em diferentes estudos, porém para carcinomas de células escamosas, onde $K L K^{\gamma}$ foi identificado com expressão aumentada em carcinoma cervical, é possível que a expressão de KLK10 siga o mesmo padrão. Como nos trabalhos citados anteriormente não foi avaliada a presença de HPV nos tumores, é possível que a variação da expressão do KLK10 seja modulada, particularmente em CaPe, pela presença do vírus já que esse gene foi identificado com expressão diferencial durante a comparação entre as amostras positivas e negativas para infecção pelo HPV.

Outro gene identificado como candidato a driver, o SOX14, pertence à família SOX, composta por fatores de transcrição de alta mobilidade. A proteína Sox se liga ao DNA através do reconhecimento de uma sequência hexamérica de nucleotídeos 5'-(A/T)(A/T)CAA(A/T)-3', embora a sequência consenso não seja o único fator que influencia nessa ligação (Harley et al., 1994; Mertin et al. , 1999; Tanaka et al. , 2004). Ao contrário da maioria dos fatores de transcrição, os membros da família SOX preferem se ligar no sulco menor do DNA, local onde a estrutura da cromatina é modificada. Essa ligação possibilita a formação do "enhanceossomo" (do inglês, enhanceosome), onde o enhancer e os reguladores associados a ele atuam coordenada e cooperativamente, de modo que alterações mínimas em sítios de ligação podem acarretar efeitos drásticos na transcrição. Devido à sua menor afinidade de ligação ao DNA, é sugerido que proteínas Sox trabalhem em conjunto com outros fatores de transcrição, tais como POU5F1(Oct3/4), proteínas zinc finger, helix-loop-helix e proteínas zíper de leucina para o funcionamento apropriado (Aksoy et al. , 2013). As proteínas Sox desempenham um papel importante na regulação do ciclo celular e são essenciais durante o desenvolvimento do sistema nervoso, embrionário e câncer (Castillo e Sanchez-Cespedes, 2012). Nestes processos, elas são capazes de regular a expressão de genes como ativadores ou repressores transcricionais dependendo do alvo celular e contextos. Além disso, a atividade das proteínas Sox também poderia ser modulada durante os processos de fosforilação, sumoilação e/ou ubiquitinação (Liu et al. , 2013).

O gene SOX2, fator de transcrição de células tronco, é responsável pela reprogramação de células somáticas humanas para células tronco pluripotentes, assim como NANOG e OCT4. É o membro da familia mais descrito em carcinoma de células escamosas e a expressão aumentada desse gene foi descrita em todos os tipos de carcinomas de pulmão, incluindo carcinoma de células escamosas (CCE) e adenocarcinomas (Karachaliou et al. , 2013). Ao contrário do SOX2, há poucos relatos sobre o gene $S O X 14$ em carcinomas de células escamosas. A diminuição dos níveis de metilação desse gene já foi descrita por Tong et al. (2010) em leucemia linfocítica aguda crônica. No presente estudo, considerando a comparação entre tumores positivos e negativos para a infecção pelo HPV, foram identificados altos níveis de metilação no gene SOX14. É possível que infecção viral seja responsável pela tumorigênese de pênis, pelo menos em uma parcela dos casos. Em amostras HPV negativas é possível que uma segunda via seja responsável pelo desenvolvimento de $\mathrm{CaPe}$ em decorrência dos baixos níveis de metilação e posterior desregulação da proteína associada com células tronco tumorais. Reforçando essa hipótese, foram observados em amostras HPV negativas genes alterados na via do NOTCH e WNT, bem como hipometilação de NOTCH1. A via do WNT desempenha um papel importante no desenvolvimento, migração e adesão de células e a alteração na regulação dessa via tem sido relacionada com transformação neoplásica por Ochoa-Hernandez et al. (2012). A via do NOTCH atua principalmente no desenvolvimento de células embrionárias e diversificação celular (Albertson et al. , 2004). Ex- 
pressão aumentada de NOTCH1 foi relatada por Villanueva et al. (2012) em diversos tumores, incluindo hepatoblastoma. Em pesquisas no PUBMED não foram encontrados estudos sobre a ação de miRNAs como possíveis reguladores do gene SOX14. Esse gene também não foi identificado como alvo dos miRNAs avaliados no presente estudo, sugerindo o controle desse gene por outros mecanismos.

O gene $R F C 4$, mapeado em $3 \mathrm{q} 27$, é responsável por diversas funções, como por exemplo, reparo do DNA, replicação do DNA e manutenção dos telômeros e participa das vias do ciclo celular, BRCA1, ATR, checkpoint das fases G2/M, entre outras. Esse gene foi relacionado a uma via enriquecida para o ciclo celular e altos níveis desse transcrito já foram relatados em carcinomas de ânus, cervical e cabeça e pescoço (Kreuter et al. , 2010; Santin et al. , 2005; Slebos et al. , 2006). No estudo de Slebos et al. (2006), das 36 amostras avaliadas para carcinoma de cabeça e pescoço, 15 foram de cavidade oral, nove de orofaringe, nove de laringe e três de hipofaringe. Os autores detectaram 7/9 (77,8\%) amostras de orofaringe com infecção pelo HPV e nenhuma na cavidade oral. Ainda nesse estudo, 91 genes diferencialmente expressos foram obtidos na comparação entre amostras positivas e negativas para infecção pelo HPV em HNSCC, dos quais se destacam o RFC4, PCNA e CDKN2A (altos níveis de expressão), sendo que os dois primeiros foram identificados como possíveis drivers pela metodologia proposta nesse trabalho. Aqui, o $R F C 4$ foi identificado com ganho genômico e perda de metilação da região promotora, sugerindo ambos os mecanismos como possíveis responsáveis pela expressão aumentada desse gene. Além disso o $R F C 4$ foi identificado como regulador do módulo enriquecido para ciclo celular, sugerindo o estudo dos genes presentes nessa via para caracterização do papel do HPV na tumorigênese.

O antígeno nuclear de proliferação celular (PCNA), mapeado em 20p12, foi identificado em uma região com ganho de segmento e apresenta altos níveis de transcritos codificadores e perda de metilação da região promotora do DNA. Assim como o gene $R F C 4$, o $P C N A$ atua em diversos processos relacionados com o ciclo celular, como reparo do DNA, proliferação celular, transição da fase G1/S e manutenção dos telômeros. A expressão aumentada desse gene foi relatada em câncer de pulmão por Soria et al. (2000), Gorgoulis et al. (2002), Singhal et al. (2003) e Cooper et al. (2006). Em carcinoma cervical, Branca et al. (2007) encontraram associação entre a expressão aumentada do PCNA e amostras positivas para a infecção de HPVs de alto risco. Especificamente em carcinoma de pênis, Martins et al. (2002) e Guimaraes et al. (2006) avaliaram a expressão da proteína PCNA e sua correlação com características clínicas e patológicas. Enquanto Martins et al. (2002) não encontraram associação entre a expressão da proteína e características prognósticas, Guimaraes et al. (2006) revelaram correlação entre a expressão de PCNA e o desenvolvimento de metástases linfonodais. No presente estudo esse gene não foi correlacionado com características clínicas ou patológicas. De acordo com a literatura, diversos marcadores moleculares foram associados à predição de comprometimento linfonodal em tumores de pênis, como por exemplo, o padrão de expressão das proteínas TP53, Ki-67 e $P C N A$ que foi correlacionado positivamente com envolvimento linfonodal em pacientes com CaPe (Guimaraes et al. , 2006; Lopes et al. , 2002; Protzel et al. , 2007). Acredita-se o PCNA apresente papel na oncogênese mediada por HPV devido à sua ligação à p21, a qual modula a duplicação do DNA dependente de PCNA. No entanto, a proteína E7 do HPV16 é capaz de substituir essa modulação e desregular o controle do ciclo celular (Funk et al. , 1997; Jones et al. , 1997; Melendy et al. , 1995). Assim como descrito anteriormente, o miRNA predito como regu- 
lador do gene PCNA (hsa-miR-154) atua na via do ciclo célular através da regulação da ciclina CCND2 e ativação das $C D K 4$ e $C D K 6$, que posteriormente fosforilam a pRb, resultando no aumento da expressão do E2F. Segundo Gupta et al. (2009), PCNA, CCND2 e CDK4 são fatores essenciais na primeira etapa de progressão do ciclo celular (G1/S). Isso reforça o hsa-miR-154 como possível mecanismo regulador para desse gene na via.

A interação entre PCNA e RFC4 sugere uma forte participação do HPV como um dos mecanismos cruciais para a tumorigênese de CaPe. Apesar de relatos em carcinoma cervical Buitrago-Perez et al. (2009) e de orofaringe (Lohavanichbutr et al. , 2010) sobre a expressão diferencial de $R F C$ 4 e $P C N A$, para o nosso conhecimento não há relatos sobre a caracterização de ambos como drivers em tumores humanos e sobre a associação entre eles em carcinomas de células escamosas infectadas pelo vírus, sendo necessário mais estudos para elucidar o papel do HPV no desenvolvimento dessa doença. Como discutido, o HPV pode ter um papel fundamental em diversos tipos de tumores, e em câncer de pênis é esperado que o vírus atue em uma via paralela de indução tumoral. De acordo com a ação do vírus no ciclo celular, as oncoproteínas E6 e E7 antagonizam as proteínas supressoras de tumor p53 e Rb humanas, respectivamente, o que leva a alterações nas vias $p 14 A R F / M D M 2 / p 53$ e $p 16 I N K 4 a /$ ciclina $D / R b$ e interfere no controle da divisão celular e apoptose (Sarkar et al. , 1992; zur Hausen , 2009). A inativação de RB1 pela proteína E7 do vírus resulta em uma expressão elevada de p16INK4a, de forma que altas quantidades dessa proteína vêm sendo utilizadas como marcadores de envolvimento viral em alguns carcinomas (Ferreux et al. , 2003; Prowse et al. , 2008).

Assim como no estudo anterior, comparando amostras tumorais e normais, algumas medidas de rede foram utilizadas para avaliar as características topológicas dos quatro genes candidatos a drivers selecionados. Foi observado que o gene $P C N A$ apresentou a maior conectividade e valor para centralidade de intermediação, ressaltando o seu papel de hub no sistema. Sun e Zhao (2010) relatam que genes relacionados com o câncer geralmente apresentam alto grau de conectividade, alto valor de intermediação e baixo coeficiente de clusterização. Todas essas características foram observadas para o gene PCNA, o que sugere esse gene como um candidato a biomarcador para carcinomas de pênis, positivos para a infecção pelo HPV. A importância desse gene também é destacada em buscas no NCBI (acessado em 30-12-2013), onde 1.605 estudos publicados na literatura já citaram esse gene (no campo de título). Também é possível citar o gene $R F C$, que apresentou $k=17$ e valor de intermediação acima do limiar, porém inferior ao encontrado para o gene $P C N A$. Esse gene apresentou o maior valor para o coeficiente de clusterização. A associação entre $P C N A$ e $R F C 4$, participantes de etapas do ciclo celular, bem como suas características topológicas sugerem que ambos tenham um papel fundamental na atividade do vírus nas células, com uma possível interação entre as proteínas virais e os genes responsáveis pelo controle do ciclo celular. Para o gene SOX14 não foram identificadas interações nos bancos de dados utilizados e o gene $K L K 10$ apresentou baixos valores para as medidas avaliadas. Seguindo o mesmo modelo utilizado para o $P C N A$, o gene $S O X 14$ foi identificado em 18 estudos no NCBI, seguido pelo gene $K L K 10$, com 13 artigos publicados, onde o gene aparecia no campo de título. É possível que os baixos valores de centralidade estejam fortemente associados com a quantidade de publicações disponíveis na literatura, uma vez que o aumento da quantidade de estudos poderia fornecer evidências de outras proteínas relacionadas com ambos os genes.

Com relação à validação dos candidatos a driver, os genes $P C N A$ e $R F C 4$ foram avaliados 
por RT-qPCR, com expressão diferencial entre amostras positivas e negativas para infecção pelo HPV definida por $p<0,05$. A expressão aumentada de ambos os genes concordam com as alterações identificadas para os outros mecanismos estudados durante o processo de integração de dados, como por exemplo, ganhos genômicos, hipometilação e expressão diminuída dos miRNAs. Os resultados obtidos na validação in situ sugerem que a expressão aumentada de ambos os genes é importante para o desenvolvimento do carcinoma de pênis pela via de infecção pelo vírus. $\mathrm{O}$ gene $\mathrm{SOX}_{4}$ foi avaliado pelo método de pirosequenciamento e identificado com maior porcentagem de metilação em amostras HPV + em comparação com amostras HPV-, concordando com os resultados obtidos pela técnica de microarray para metilação e inversamente correlacionado com a expressão diminuída dos transcritos codificadores. O gene $K L K 10$, também identificado como candidato a driver, pode ser considerado um potencial alvo para validação futura. Assim como no estudo das alterações obtidas pela comparação entre amostras tumorais e normais de $\mathrm{CaPe}$, a falta de dados moleculares sobre câncer de pênis impede uma meta-análise diretamente relacionada com a doença. Assim, a meta-análise realizada nessa etapa considerou amostras de carcinomas de cabeça e pescoço (115) e cervical (95), obtidas de bancos de dados públicos. Outra particularidade dessa meta-análise foi a utilização de dados do banco NCBI-GEO (Gene Expression Omnibus, disponível em http://ncbi.nlm.nih.gov/geo). Ao contrário do TCGA, dados do GEO são globalmente disponibilizados por pesquisadores e obtidos a partir de diferentes plataformas sob diferentes condições. Nesse banco de dados é possível estabelecer parâmetros de busca para a escolha de um conjunto de amostras que seja a mais próxima do conjunto utilizado no estudo. Foram observados níveis semelhantes de expressão para o gene $R F C_{4}$ (expressão aumentada), em CaPe e nos outros cinco conjuntos de amostras utilizados. A expressão aumentada do gene PCNA também foi concordante com os estudos de carcinoma de cabeça e pescoço (disponível no TCGA) e dois estudos sobre carcinoma cervical e um sobre cabeça e pescoço (disponíveis no NCBI-GEO. Observa-se também que a expressão aumentada do gene KLK10 é discordante dos outros conjuntos amostrais. Koh et al. (2012) relataram que KLK6, KLK10 e KLK11 estão presentes com expressão aumentada na maioria do carcinomas de ovário em estágios avançados da doença. É possível que o gene KLK10 siga o mesmo padrão nas amostras de pacientes com etapas mais avançadas no desenvolvimento do carcinoma de pênis. Já a expressão diminuída do gene SOX14 em CaPe também foi observada no estudo com amostras de carcinoma cervical disponível no TCGA e com outros dois conjuntos de amostras obtidas no NCBI-GEO (carcinoma cervical e de cabeça e pescoço, disponível no estudo GSE6791).

Os resultados obtidos em todo o estudo demonstram que a análise integrada de diferentes mecanismos de alteração, como a expressão diferencial de transcritos codificadores, metilação da região promotora, regulação por miRNAs e alteração no número de cópias genômicas, são úteis na identificação de genes relacionados ao carcinoma de pênis. Além disso, a análise integrada permitiu identificar genes específicos responsáveis por um perfil genético característico quanto à infecção pelo HPV.

Devido às limitações das técnicas utilizadas e da metodologia proposta para inferir que um gene é driver em uma determinada doença são necessários outros experimentos, como por exemplo, um estudo com RNA de interferência (RNAi) para silenciamento do gene candidato em modelo animal ou linhagem celular. Entretanto, a integração de múltiplas informações é um mecanismo eficiente de seleção de candidatos com alto potencial tumorigênico. Além disso, a 
associação entre os genes avaliados com interações proteína-proteína e genes passengers são aditivos importantes que podem auxiliar na escolha de vias biológicas relevantes para CaPe, tanto pela via intrínseca, em que a ativação de diferentes classes de oncogenes leva à expressão de genes específicos e subseqÃijente desenvolvimento de um ambiente inflamatório, quanto pela via extrínseca, incluindo a infecção por HPV, a qual estaria associada ao desenvolvimento do câncer. É importante ressaltar que esse é o primeiro estudo molecular em larga escala sobre câncer de pênis, e por esse motivo, fica impossibilitada a comparação com estudos prévios para validação in sílico. Em alguns casos os resultados não foram concordantes com a literatura de outros tumores, porém, em CaPe, podem desempenhar um papel importante, sendo que todas as alterações foram identificadas com alta frequência. Tentando contornar esse viés, durante a discussão, foram apresentados inúmeros relatos envolvendo alterações identificadas em carcinomas de células escamosas, pois alterações nesse tipo de tecido teriam maior semelhança com alterações no carcinoma de pênis e maior relação com uma possível influência do vírus no desenvolvimento do tumor. 


\section{CONCLUSÕES}

\section{INTEGRAÇÃO DE DADOS}

A metodologia de integração de dados foi responsável pela seleção de 73 genes pré-candidatos a drivers em CaPe, dos quais 17 (BIRC5, DNMT1, DTX2, FLI1, CAV1, MSX1, DLC1, TNFSF10, NRAS, NRN1, PLCB3, PML, PPARG, RB1, RUNX3, SOX17 e TWIST1) foram selecionados como candidatos a drivers. Considerando genes diferencialmente expressos entre grupos positivos e negativos para infecção pelo HPV, a primeira etapa de integração de dados selecionou 35 genes, dos quais apenas quatro ( $P C N A, R F C 4, S O X 14$ e $K L K 10)$ foram selecionados como candidatos a drivers. Em ambas as análises, foram identificados oncogenes e supressores tumorais enriquecidos para vias essenciais para o desenvolvimento tumoral, como por exemplo, ciclo celular, regulação da transcrição e processo inflamatório. A análise de propriedades topológicas revelou genes considerados hubs, cujo papel na estrutura da rede sugere sua importância na comunicação entre genes no sistema celular. A análise dos processos biológicos alterados e dos genes com alta conectividade das redes revelou correlação entre a infecção pelo HPV e alterações em genes associados com a modulação do sistema imune e promoção de inflamação. Estes dados sugerem que a infecção pelo vírus é capaz de alterar os mecanismos de defesa do sistema imune, o que por sua vez pode levar ao desenvolvimento da inflamação e contribuir para o processo tumoral. Quando a metodologia foi aplicada ao conjunto de 255 amostras de glioblastoma multiforme e validada em comparação a uma lista de 56 genes de referência foram identificados genes como PTEN, RB1, TP53, EGFR e CDKN2A, bem característicos por seu envolvimento no GBM e presentes na lista de referência.

\section{REDES EM MÓDULOS}

Utilizando um conjunto de 255 amostras de expressão gênica de glioblastoma multiforme foram identificados genes já descritos na literatura devido a associação com a doença, tanto pelas metodologias de Segal et al. (2003) e Michoel et al. (2007), quanto pelo método adaptado proposto nesse estudo. Quando avaliada a interação entre drivers e genes do módulo foi identificado um ganho na identificação de predições verdadeiro-positivas com o método proposto. Também foram identificados os maiores valores de sensibilidade e especificidade para deteç̧ão de genes passengers e genes presentes na lista de referência em comparação com os outros dois métodos avaliados. Ainda, os genes passengers presentes nos módulos sugere novos mecanismos para alterações de vias essenciais relacionadas ao câncer. A alteração da metodologia proposta nesse estudo atende a inclusão de novos mecanismos que possam estabelecer uma associação maior entre genes reguladores (driver) e genes regulados (genes co-expressos presentes nos módulos), fundamental para identificação de vias que estejam diretamente relacionadas com o desenvolvimento do câncer de pênis. 


\section{Referências}

Aebersold e Goodlett (2001) R. Aebersold e D. R. Goodlett. Mass spectrometry in proteomics. Chemical Reviews, 2(101):269-296. Citado na pág. 88

Akalin et al. (2013) I. Akalin, S. Bozdag, M. Spielmann, S. Y. Basaran, I. Nanda e E. Klopocki. Partial trisomy 1q41-qter and partial trisomy 9pter-9q21.32 in a newborn infant: An array cgh analysis and review. Am J. Med Genet A. and, 2(164):490-494. Citado na pág. 5

Akavia et al. (2010) U. D. Akavia, O. Litvin, J. Kim, F. Sanchez-Garcia, D. Kotliar, H. C. Causton, E. M. Pochanard, L. A. Garraway e D. Pe'er. An integrated approach to uncover drivers of cancer. Cell, 143:1005-1017. Citado na pág. 5, 9, 82

Aksoy et al. (2013) I. Aksoy, R. Jauch, V. Eras, A. C. Bin, J. Chen, U. Divakar, C. K. Ng, P. R. Kolatkar e L. W. Stanton. Sox transcription factors require selective interactions with oct4 and specific transactivation functions to mediate reprogramming. STEM CELLS, 12(31): 2632-2646. Citado na pág. 106

Al-Shahrour et al. (2004) F. Al-Shahrour, R. Diaz-Uriarte e J. Dopazo. Fatigo: a web tool for finding significant associations of gene ontology terms with groups of genes. Bioinformatics, 20(4):578-80. Citado na pág. 8

Albertson et al. (2004) D. G. Albertson, C. Collins, F. McCormick e J. W. Gray. Chromosome aberrations in solid tumors. Nat Genet, 4(34):369-376. Citado na pág. 5, 106

Altucci et al. (2007) L. Altucci, M. D. Leibowitz, K. M. Ogilvie, de A. R. Lera e H. Gronemeyer. Rar and rxr modulation in cancer and metabolic disease. Nature Biotechnology, 9810(6):793810. Citado na pág. 99

Alves et al. (2001) G. Alves, A. Heller, W. Fiedler, M. M. Campos, U. Claussen, A. A. Ornellas e T. Liehr. Genetic imbalances in 26 cases of penile squamous cell carcinoma. Genes Chromosomes Cancer, 1(31):48-53. Citado na pág. 17

Ambatipudi et al. (2012) S. Ambatipudi, M. Gerstung, M. Pandey, T. Samant, A. Patil, S. Kane, R. S. Desai, A. A. Schaffer, N. Beerenwinkel e M. B. Mahimkar. Genome-wide expression and copy number analysis identifies driver genes in gingivobuccal cancers. Genes Chromosomes Cancer, 2(51):161-173. Citado na pág. 82

Ataie-Kachoie et al. (2013) P. Ataie-Kachoie, M. H. Pourgholami e D. L. Morris. Inhibition of the il-6 signaling pathway: a strategy to combat chronic inflammatory diseases and cancer. Cytokine Growth Factor Rev, 24(2):163-73. Citado na pág. 100

Backes et al. (2009) D. M. Backes, R. J. Kurman, J. M. Pimenta e J. S. Smith. Systematic review of human papillomavirus prevalence in invasive penile cancer. Cancer Causes Control, 4(20):449-457. Citado na pág. 18

Baker et al. (1990) S. J. Baker, A. C. Preisinger e J. M. Jessup. P53 genemutations occur in combination with $17 \mathrm{p}$ allelic deletionsas late events in colorectal tumorigenesis. Cancer Res, 50:7717-7722. Citado na pág. 5

Barbosa et al. (2011) L. C. Barbosa, I. D. da Silva, J. C. Corrêa e J. C. Ribalta. Survivin and telomerase expression in the uterine cervix of women with human papillomavirus-induced lesions. Int J. Gynecol Cancer, 21(1):15-21. Citado na pág. 98

Barnholtz-Sloan et al. (2007) J. S. Barnholtz-Sloan, J. L. Maldonado, J. Pow-sang e A. R. Giuliano. Incidence trends in primary malignant penile cancer. Urol Oncol, 25:361-367. Citado na pág. 16 
Basso et al. (2005) K. Basso, A. A. Margolin, G. Stolovitzky, U. Klein, R. Dalla-Favera e A. Califano. Reverse engineering of regulatory networks in human b cells. Nature Genetics, 37(4):382-390. Citado na pág. 3

Battle et al. (2005) A. Battle, E. Segal e D. Koller. Probabilistic discovery of overlapping cellular processes and their regulation. J. Comput Biol, 12:909-927. Citado na pág. 85

Bayani et al. (2013) J. Bayani, U. Kuzmanov, P. Saraon, W. A. Fung, A. Soosaipillai, J. A. Squire e E. P. Diamandis. Copy number and expression alterations of mirnas in the ovarian cancer cell line ovcar-3: Impact on kallikrein 6 protein expression. Bioinformatics, 59(1):296305. Citado na pág. 6

Bellman e Rand (1957) R. E. Bellman e C. Rand. Dynamic programming. Princeton University Press, Princeton and NJ and USA, 1 ed. Citado na pág. 16

Bentink et al. (2012) S. Bentink, B. Haibe-Kains, T. Risch, J. B. Fan e M. S. Hirsch. Angiogenic mrna and microrna gene expression signature predicts a novel subtype of serous ovarian cancer. PLoS ONE, 7(2):e30269. Citado na pág. 82

Beroukhim et al. (2007) R. Beroukhim, G. Getz, L. Nghiemphu, J. Barretina, T. Hsueh, D. Linhart, I. Vivanco, J. C. Lee, J. H. Huang, S. Alexander e J. Du. Assessing the significance of chromosomal aberrations in cancer: methodology and application to glioma. Proc Natl Acad Sci USA, 104(50):20007-20010. Citado na pág. 33

Bezerra et al. (2001) A. L. Bezerra, A. Lopes, G. H. Santiago, K. C. Ribeiro, M. R. Latorre e L. L. Villa. Human papillomavirus as a prognostic factor in carcinoma of the penis: analysis of 82 patients treated with amputation and bilateral lymphadenectomy. Cancer, 91:2315-2321. Citado na pág. 19, 102

Bhatia et al. (2008) B. Bhatia, M. Jiang, M. Suranemi, L. Patrawala, M. Badeaux, R. SchneiderBroussard, A. S. Multani, C. R. Jeter, T. Calhoun-Davis e L. Hu. Critical and distinct roles of p16 and telomerase in regulating the proliferative life span of normal human prostate epithelial progenitor cells. J. Biol Chem, 283(41):27957-27972. Citado na pág. 89

Bicciato et al. (2009) S. Bicciato, R. Spinelli, M. Zampieri, E. Mangano, F. Ferrari, L. Beltrame, I. Cifola, C. Peano, A. Solari e C. Battaglia. A computational procedure to identify significant overlap of differentially expressed and genomic imbalanced regions in cancer datasets. Nucleic Acids Res, 37(15):5057-5070. Citado na pág. 8

Billur et al. (2013) E. H. Billur, E. Guney, O. Keskin, B. Oliva e A. Gursoy. Integrating structure to protein-protein interaction networks that drive metastasis to brain and lung in breast cancer. PLoS ONE, 8(11):e81035. Citado na pág. 4

Bishop (1995) C. M. Bishop. Neural networks for pattern recognition. Oxford University Press. Citado na pág. 16

Bisognin et al. (2012) A. Bisognin, G. Sales, A. Coppe, S. Bortoluzzi e C. Romualdi. MagiaÂš: from mirna and genes expression data integrative analysis to microrna-transcription factor mixed regulatory circuits (2012 update). Nucleic Acids Res, 40:W13-21. Citado na pág. 7

Bonnet et al. (2010) E. Bonnet, M. Tatari, A. Joshi, T. Michoel, K. Marchal, G. Berx e Y. Van de Peer. Module network inference from a cancer gene expression data set identifies microrna regulated modules. PLoS One, 5(4):e10162. Citado na pág. 85

Bovolenta et al. (2012) L. A. Bovolenta, M. L. Acencio e N. Lemke. Htridb: an open-access database for experimentally verified human transcriptional regulation interactions. $B M C G e-$ nomics, 13:405. Citado na pág. 40 
Bowles et al. (2000) J. Bowles, G. Schepers e P. Koopman. Phylogeny of the sox family of developmental transcription factors based on sequence and structural indicators. Dev Biol, 227(2):239-255. Citado na pág. 96

Bozic et al. (2010) I. Bozic, T. Antal, H. Ohtsuki, H. Carter, D. Kim, S. Chen, R. Karchin, K. W. Kinzler, B. Vogelstein e M. A. Nowak. Accumulation of driver and passenger mutations during tumor progression. PNAS, 7(43):18545-18550. Citado na pág. 1

Braakhuis et al. (2013) B. J. M. Braakhuis, M. M. Rietbergen, M. Buijze, P. J. F. Snijders, E. Bloemena, R. H. Brakenhoff e C. R. Leemans. Tp53 mutation and human papilloma virus status of oral squamous cell carcinomas in young adult patients. Oral Disease, 19(8). Citado na pág. 100

Branca et al. (2007) M. Branca, M. Ciotti, C. Giorgi, D. Santini, L. Di Bonito, S. Costa, A. Benedetto, D. Bonifacio, P. Di Bonito, P. Paba, L. Accardi, S. Syrjanen, C. Favalli e K. Syrjanen. Up-regulation of proliferating cell nuclear antigen (pcna) is closely associated with high-risk human papillomavirus (hpv) and progression of cervical intraepithelial neoplasia (cin) and but does not predict disease outcome in cervical cancer. Eur J. Obstet Gynecol Reprod Biol, 130(2):223-231. Citado na pág. 104, 107

Brown et al. (2012) J. R. Brown, M. Hanna, B. Tesar, L. Werner, N. Pochet, J. M. Asara, Y. E. Wang, P. Dal Cin, S. M. Fernandes, C. Thompson e et al. Integrative genomic analysis implicates gain of pik3ca at 3q26 and myc at 8q24 in chronic lymphocytic leukemia. J. Biol Chem, 18(14):3791-3802. Citado na pág. 5

Brukner et al. (2009) A. Brukner, C. Polge, N. Lentze, D. Auebach e U. Schlattner. Yeast two-hybrid, a powerful tool for systems biology. Int. J. Mol. Sci, 10:2763-2788. Citado na pág. 87

Brunelli et al. (2012) M. Brunelli, E. Bria, A. Nottegar, S. Cingarlini, F. Simionato, A. Caliò, A. Eccher, C. Parolini, A. Iannucci, E. Gilioli e et al. True 3q chromosomal amplification in squamous cell lung carcinoma by fish and acgh molecular analysis: impact on targeted drugs. PLoS One, 7(12):e49689. Citado na pág. 90

Buitrago-Perez et al. (2009) A. Buitrago-Perez, G. Garaulet, A. Vazquez-Carballo e J. M. Paramio e R. Garcia-Escudero. Molecular signature of hpv-induced carcinogenesis: prb and p53 and gene expression profiling. Curr Genomics, 10(1):26-34. Citado na pág. 108

Busso (2012) Ariane Fidelis Busso. Alteração no numero de copias genomicas e expressão genica em larga escala em carcinomas de penis. Phd in oncology, AC Camargo Cancer Center. Citado na pág. 72,90

Byrav et al. (2013) D. S. P. Byrav, B. Medhi, A. Prakash, A. Chakrabarti, K. Vaiphei e K. L. Khanduja. Comparative evaluation of different doses of ppar- $\gamma$ agonist alone and in combination with sulfasalazine in experimentally induced inflammatory bowel disease in rats. Pharmacol Rep, 65(4):951-959. Citado na pág. 100

Call et al. (1990) K. M. Call, T. Glaser, C. Y. Ito, A. J. Buckler, J. Pelletier, D. A. Haber, E. A. Rose, A. Kral, H. Yeger e W. H. Lewis. Isolation and characterization of a zinc finger polypeptide gene at the human chromosome 11 wilms' tumor locus. Cell, 60:509-520. Citado na pág. 88

Cao et al. (2009) L. K. Cao, P. Martin, C. Robert-Granie e P. Besse. Sparse canonical methods for biological data integration: application to a cross-platform study. BMC Bioinformatics, 10 : 26-34. Citado na pág. 89 
Capaccione e Pine (2013) K. M. Capaccione e S. R. Pine. The notch signaling pathway as a mediator of tumor survival. Carcinogenesis, 34(7):1420-1430. Citado na pág. 99

Careccia et al. (2009) S. Careccia, S. Mainardi, A. Pelosi, A. Gurtner, D. Diverio, R. Riccioni, U. Testa, E. Pelosi, G. Piaggio, A. Sacchi e et al. A restricted signature of mirnas distinguishes apl blasts from normal promyelocytes. Oncogene, 28(45):4034-4040. Citado na pág. 94

Carracedo et al. (2008) A. Carracedo, L. Ma, J. Teruya-Feldstein, F. Rojo, L. Salmena, A. Alimonti, A. Egia, A. T. Sasaki, G. Thomas e S. C. Kozma. Inhibition of mtorc1 leads to mapk pathway activation through a pi3k-dependent feedback loop in human cancer. J. Clin Invest, 118(9):3065-3074. Citado na pág. 2

Carrasco et al. (2011) R. A. Carrasco, N. B. Stamm, E. Marcusson, G. Sandusky, P. Iversen e B. K. Patel. Antisense inhibition of survivin expression as a cancer therapeutic. Mol Cancer Ther, 10(2):221-232. Citado na pág. 98

Castellsague et al. (2002) X. Castellsague, F. X. Bosch, N. Munoz, C. J. Meijer, K. V. Shahand, S. de Sanjose, J. Eluf-Neto, C. A. Ngelangel, S. Chichareon e J. S. Smith. Male circumcision and penile human papillomavirus infection and and cervical cancer in female partners. $N$. Engl J. Med, 346:1105-1112. Citado na pág. 102

Castillo e Sanchez-Cespedes (2012) S. D. Castillo e M. Sanchez-Cespedes. The sox family of genes in cancer development: biological relevance and opportunities for therapy. Expert Opin Ther Targets, 16(9):903-919. Citado na pág. 106

Cavenee et al. (1983) W. K. Cavenee, T. P. Dryja e R. A. Phillips. Expression ofrecessive alleles by chromosomal mechanisms in retinoblastoma. Nature, 305:779-784. Citado na pág. 5

Cen et al. (2012) L. Cen, B. L. Carlson, M. A. Schroeder, J. L. Ostrem, G. J. Kitange, A. C. Mladek, S. R. Fink, P. A. Decker, W. Wu e J. S. Kim. p16-cdk4-rb axis controls sensitivity to a cyclin-dependent kinase inhibitor pd0332991 in glioblastoma xenograft cells. Neuro Oncol, 14(7):870-881. Citado na pág. 84

Cesare et al. (2013) A. J. Cesare, M. T. Hayashi, L. Crabbe e J. Karlseder. The telomere deprotection response is functionally distinct from the genomic dna damage response. J. Biol Chem, 51(2):141-155. Citado na pág. 99

Chari et al. (2006) R. Chari, W. W. Lockwood, B. P. Coe, A. Chu, D. Macey, A. Thomson, J. J. Davies, C. MacAulay e W. L. Lam. Sigma: a system for integrative genomic microarray analysis of cancer genomes. BMC Genomics, 7:324. Citado na pág. 8

Chen et al. (2008) X. Chen, Y. Ba, L. Ma, X. Cai, Y. Yin, K. Wang, J. Guo, Y. Zhang, J. Chen, X. Guo e et al. Characterization of micrornas in serum: a novel class of biomarkers for diagnosis of cancer and other diseases. Cell Res, 18(10):997-1006. Citado na pág. 12

Cho et al. (2012) Y. H. Cho, J. Shen, M. D. Gammon, Y. J. Zhang, Q. Wang, K. Gonzalez, X. Xu, P. T. Bradshaw, S. L. Teitelbaum, G. Garbowski e et al. Prognostic significance of gene-specific promoter hypermethylation in breast cancer patients. Breast Cancer Res Treat, 131(1):197-205. Citado na pág. 96

Chung et al. (2013) C. H. Chung, A. Bagheri e G. D. Souza. Epidemiology of oral human papillomavirus infection. Oral Oncology. Citado na pág. 19

Cirilo et al. (2013) P. D. Cirilo, F. A. Marchi, M. C. Barros-Filho, R. M. Rocha, M. A. Domingues, I. Jurisica, A. Pontes e S. R. Rogatto. An integrative genomic and transcriptomic analysis reveals potential targets associated with cell proliferation in uterine leiomyomas. PLoS One, 8(3):e57901. Citado na pág. 5, 9 
Colangelo et al. (15) T. Colangelo, A. Fucci, C. Votino, L. Sabatino, M. Pancione, C. Laudanna, M. Binaschi, M. Bigioni, C. A. Maggi, D. Parente, N. Forte e V. Colantuoni. Microrna$130 \mathrm{~b}$ promotes tumor development and is associated with poor prognosis in colorectal cancer. Neoplasia, 9:1086-1099. Citado na pág. 93

Colas et al. (2012) A. R. Colas, W. L. McKeithan, T. J. Cunningham, P. J. Bushway, L. X. Garmire, G. Duester e S. Subramaniam e M. Mercola. Whole-genome microrna screening identifies let-7 and mir-18 as regulators of germ layer formation during early embryogenesis. Genes Dev, 26(23):2567-2579. Citado na pág. 96

Conde et al. (2007) L. Conde, D. Montaner, J. Burguet-Castell, J. Tarraga, I. Medina, F. AlShahrour e J. Dopazo. Isacgh: a web-based environment for the analysis of array cgh and gene expression which includes functional profiling. Nucleic Acids Res, 35:81-85. Citado na pág. 8

Cooper et al. (2006) C. S. Cooper, A. G. Nicholson e C. Foster. Nuclear overexpression of the e. 2f. 3 transcription factor in human lung cancer. Lung Cancer, 54:155-162. Citado na pág. 107

Croce et al. (2002) L. Di Croce, V. A. Raker, M. Corsaro, F. Fazi, M. Fanelli, M. Faretta, F. Fuks, F. Lo Coco, T. Kouzarides e C. Nervi. Methyltransferase recruitment and dna hypermethylation of target promoters by an oncogenic transcription factor. Science, 8(295): 1079-1082. Citado na pág. 95

Cubilla et al. (1998) A. L. Cubilla, V. E. Reuter e L. Gregoire. Basaloid squamous cell carcinoma: a distinctive human papilloma virus-related penile neoplasm: a report of 20 cases. Am J. Surg Pathol, 22:755-761. Citado na pág. 18, 103

Cubilla et al. (2004) A. L. Cubilla, E. F. Velazquez e R. H. Young. Epithelial lesions associated with invasive penile squamous cell carcinoma: a pathologic study of 288 cases. Int J. Surg Pathol, 12:351-64. Citado na pág. 17

Dall et al. (2008) K. L. Dall, C. G. Scarpini e I. Roberts. Characterization of naturally occurring hpv16 integration sites isolated from cervical keratinocytes under noncompetitive conditions. Cancer Res, 68:8249-8259. Citado na pág. 18

Dasgupta et al. (2006) S. Dasgupta, P. K. Tripathi, H. Qin, M. Bhattacharya-Chatterjee, J. Valentino e S. K. Chatterjee. Identification of molecular targets for immunotherapy of patients mendwith head and neck squamous cell carcinoma. Oral Oncol, 42(3):306-316. Citado na pág. 105

Davis et al. (2008) M. E. Davis, Z. G. Chen e D. M. Shin. Nanoparticle therapeutics: an emerging treatment modality for cancer. Nat Rev Drug Discov, 7(9):771-782. Citado na pág. 100

De-Carvalho et al. (2012) D. D. De-Carvalho, S. Sharma, J. S. You, S. F. Su, P. C. Taberlay, T. K. Kelly, X. Yang, G. Liang e P. A. Jones. Dna methylation screening identifies driver epigenetic events of cancer cell survival. Cancer Cell, 21(5):655-667. Citado na pág. 81

de Melo Maia et al. (2013) B. de Melo Maia, A. M. Lavorato-Rocha, L. S. Rodrigues, C. M. Coutinho-Camillo, G. Baiocchi, M. M. Stiepcich, R. Puga, L. Lima, F. A Soares e R. M. Rocha. microrna portraits in human vulvar carcinoma. Cancer Prev Res, 6(11):1231-1241. Citado na pág. 89

de Villiers et al. (2004) E. M. de Villiers, C. Fauquet, T. R. Broker, H. U. Bernard e H. zur Hausen. Classification of papillomaviruses. Virology, 324:17-27. Citado na pág. 17

Dean e Kanazawa (1989) T. Dean e K. Kanazawa. A model for reasoning about persistence and causation. Computational Intelligence, 5:142-150. Citado na pág. 14 
Dhar et al. (2001) S. Dhar, R. Bhargava, M. Yunes, B. Li, J. Goyal, S. P. Naber, D. E. Wazer e V. Band. Analysis of normal epithelial cell specific-1 (nes1)/kallikrein 10 mrna expression by in situ hybridization and a novel marker for breast cancer. Clin Cancer Res, 7:3393-3383. Citado na pág. 105

Dianzani et al. (1998) C. Dianzani, M. Bucci, A. Pierangeli, S. Calvieri e A. M. Degener. Association of human papillomavirus type 11 with carcinoma of the penis. Urology, 51:10461048. Citado na pág. 103

Diaz-Uriarte et al. (2007) R. Diaz-Uriarte, A. Alibes, E. R. Morrissey, A. Canada, O. M. Rueda e M. L. Neves. Asterias: integrated analysis of expression and acgh data using an opensource and web-based and parallelized software suite. Nucleic Acids Res, 35:75-80. Citado na pág. 7

Dicitore et al. (2013) A. Dicitore, M. Caraglia, A. Colao, S. Zappavigna, D. Mari, L. J. Hofland, L. Persani e G. Vitale. Combined treatment with ppar- $\gamma$ agonists in pancreatic cancer: a glimmer of hope for cancer therapy?. Curr Cancer Drug Targets, 13(4):460-471. Citado na pág. 100

Dmitriev et al. (2013) P. Dmitriev, A. Barat, A. Polesskaya, M. J. O'Connell, T. Robert, P. Dessen, T. A. Walsh, V. Lazar, A. Turki, G. Carnac e et al. Simultaneous mirna and mrna transcriptome profiling of human myoblasts reveals a novel set of myogenic differentiationassociated mirnas and their target genes. BMC Genomics, 14:265. Citado na pág. 89

Dougherty (2007) E. R. Dougherty. Validation of inference procedures for gene regulatory networks. Current Genomics, 8(6):351-359. Citado na pág. 13

Dowdy e Eaton (1984) S. F. Dowdy e E. N. Eaton. Function of ahuman cyclin gene as an oncogene. Proc Natl Acad Sci USA, 91:709-713. Citado na pág. 5

Du et al. (2009) Y. C. Du, H. Oshima, K. Oguma, T. Kitamura, H. Itadani, T. Fujimura, Y. S. Piao, T. Yoshimoto, T. Minamoto, H. Kotani e et al. Induction and downregulation of sox17 and its possible roles during the course of gastrointestinal tumorigenesis. Gastroenterology, 137(4):1346-1357. Citado na pág. 97

Durkin et al. (2005) M. E. Durkin, M. R. Avner, C. G. Huhand B. Z. Yuan, S. S. Thorgeirsson e N. C. Popescu. Dlc-1 and a rho gtpase-activating protein with tumor suppressor function and is essential for embryonic development. FEBS Lett, 579(5):1191-1196. Citado na pág. 92

Eble et al. (2004) J. N. Eble, G. Sauter e J. I. Epstein. Pathology and genetics of tumours of the urinary system and male genital organs., volume 7. Lyon: IARC Press. Citado na pág. 17

El-Sherbini et al. (2011) M. A. El-Sherbini, M. M. Sallam e E. A. Shabanand A. H. ElShalakany. Diagnostic value of serum kallikrein-related peptidases 6 and 10 versus ca125 in ovarian cancer. Int J. Gynecol Cancer, 21(4):625-632. Citado na pág. 105

Ell e Kang (2013) B. Ell e Y. Kang. Transcriptional control of cancer metastasis. Trends Cell Biol, 23(12):603-611. Citado na pág. 91

Favorito et al. (2008) L. A. Favorito, A. C. Nardi, M. Ronalsa, S. C. Zequi, F. J. Sampaio e S. Glina. Epidemiologic study on penile cancer in brazil. Int Braz J. Urol, 34(5):587-591. Citado na pág. 16, 17

Feik et al. (2013) E. Feik, N. Schweifer, A. Baierl, W. Sommergruber, C. Haslinger, P. Hofer, A. Maj-Hes, S. Madersbacher e A. Gsur. Integrative analysis of prostate cancer aggressiveness. Prostate, 73(13):1413-1426. Citado na pág. 5 
Feldman et al. (2008) I. Feldman, A. Rzhetsky e D. Vitkup. Network properties of genes harboring inherited disease mutations. Proc Natl Acad Sci USA, 105:4323-4328. Citado na pág. 13

Ferreux et al. (2003) E. Ferreux, A. P. Lont e S. Horenblas. Evidence for at least three alternative mechanisms targeting the p16ink4a. /cyclin $\mathrm{d}$./rb pathway in penile carcinoma and one of which is mediated by high-risk human papillomavirus. J. Pathol, 201:109-118. Citado na pág. 108

Ficarra et al. (2002) V. Ficarra, N. Maffei, I. Piacentini, N. Al-Rabi, M. A. Cerruto e W. Artibani. Local treatment of penile squamous cell carcinoma. Urol Int, 69:169-173. Citado na pág. 17

Flaherty et al. (2010) K. T. Flaherty, I. Puzanov, K. B. Kim, A. Ribas, G. A. McArthur, J. A. Sosman, P. J. O'Dwyer, R. J. Lee, J. F. Grippo, K. Nolop e et al. Inhibition of mutated and activated braf in metastatic melanoma. N. Engl J. Med, 363:809-819. Citado na pág. 3

Frattini et al. (2013) V. Frattini, V. Trifonov, J. M. Chan, A. Castano, M. Lia, F. Abate, S. T. Keir, A. X. Ji, P. Zoppoli, F. Niola e et al. The integrated landscape of driver genomic alterations in glioblastoma. Nature Genetics, 45:1141-1149. Citado na pág. 42, 77, 84

Fraunholz et al. (2012) I. Fraunholz, C. Rodel, L. Distel, M. Rave-Frank, D. Kohler, S. Falk e F. Rodel. High survivin expression as a risk factor in patients with anal carcinoma treated with concurrent chemoradiotherapy. Radiat Oncol, 7:88. Citado na pág. 98

Freeman (1978) L. C. Freeman. Centrality in social networks conceptual clarification. Social Networks, 1:215-239. Citado na pág. 11

Friedman e Meulman (2003) J. H. Friedman e J. J. Meulman. Multiple additive regression trees with application in epidemiology. Stat Med, 22(9):1365-1381. Citado na pág. 28

Friedman et al. (1999) N. Friedman, M. Goldszmidt e A. Wyner. Data analysis with bayesian networks: A bootstrap approach. In Proceedings Thirteenth Conference on Uncertainty in Artificial Intelligence, páginas 206-215. Citado na pág. 14

Friedman et al. (2000) N. Friedman, M. Linial, I. Nachman e D. Pe'er. Using bayesian networks to analyze expression data. J. Comput Biol, 7:601-620. Citado na pág. 3, 85

Fu et al. (2010) D. Y. Fu, Z. M. Wang, Li-Chen, B. L. Wang, Z. Z. Shen, W. Huang e Z. M. Shao. Sox17 and the canonical wnt antagonist and is epigenetically inactivated by promoter methylation in human breast cancer. Breast Cancer Res Treat, 119(3):601-612. Citado na pág. 96

Funk et al. (1997) J. O. Funk, S. Waga, J. B. Harry, E. Espling, B. Stillman e D. A. Galloway. Inhibition of cdk activity and pcna-dependent dna replication by $\mathrm{p} 21$ is blocked by interaction with the hpv-16 e. 7 oncoprotein. Genes Dev, 11:2090-2100. Citado na pág. 107

Galliher-Beckley et al. (2008) A. J. Galliher-Beckley, J. G. Williams, J. B. Collins e J. A. Cidlowski. Gsk3 $\beta$-mediated serine phosphorylation of the human glucocortoid receptor redirects gene expression profiles. Mol Cell Biol, 28:7309-7322. Citado na pág. 89

Garber et al. (2001) M. E. Garber, O. G. Troyanskaya, K. Schluens, S. Petersen, Z. Thaesler, M. Pacyna-Gengelbach, M. van de Rijn, G. D. Rosen, C. M. Perou, R. I. Whyte e et al. Diversity of gene expression in adenocarcinoma of the lung. Proc Natl Acad Sci USA, 98: 13784-13789. Citado na pág. 105 
Garraway et al. (2005) L. A. Garraway, H. R. Widlund, M. A. Rubin, G. Getz, A. J. Berger, S. Ramasw-amy, R. Beroukhim, D. A. Milner, S. R. Granter e J. Du. Integrative genomic analyses identify mitf as a lineage survival oncogene amplified in malignant melanoma. Nature, 436:117-122. Citado na pág. 81

Geman e Geman. (1984) S. Geman e D. Geman. Stochastic relaxation and gibbs distributions and and the bayesian restoration of images. Pattern Analysis and Machine Intelligence, 6(6): 721-741. Citado na pág. 85

Gerhauser (2013) C. Gerhauser. Cancer chemoprevention and nutriepigenetics: state of the art and future challenges. Top Curr Chem, 329:73-132. Citado na pág. 5

Gertz et al. (2009) E. M. Gertz, K. Sengupta, M. J. Difilippantonio e T. Ried e A. A. Schaffer. Evaluating annotations of an agilent expression chip suggests that many features cannot be interpreted. BMC Genomics, 10:566. Citado na pág. , 35, 36, 89

Gevaert e Plevritis (2013) O. Gevaert e S. Plevritis. Identifying master regulators of cancer and their downstream targets by integrating genomic and epigenomic features. Pac Symp Biocomput, páginas 123-134. Citado na pág. 81

Ghersi e Singh (2013) D. Ghersi e M. Singh. Interaction-based discovery of functionally important genes in cancers. Nucl. Acids Res, 42(4):e18. Citado na pág. 4

Godolphin e Jones (1989) W. Godolphin e L. A. Jones. Studies of the her- $2 /$ neu protooncogene in human breast and ovariancancer. Science, 244:707-712. Citado na pág. 4

Goh et al. (2007) K. I. Goh, M. E. Cusick, D. Valle, B. Childs, M. Vidal e A. L. Barabasi. The human disease network. Proc. Natl Acad. Sci. USA, 104:8685-8690. Citado na pág. 13, 100

Goldhoff et al. (2012) P. Goldhoff, J. Clarke, I. Smirnov, M. S. Berger, M. D. Prados, C. D. James e A. Perry e J. J. Phillips. Clinical stratification of glioblastoma based on alterations in retinoblastoma tumor suppressor protein (rb1) and association with the proneural subtype. J. Neuropathol Exp Neurol, 71(1):83-89. Citado na pág. 97

Gollin (2005) S. M. Gollin. Mechanisms leading to chromosomal instability. Semin Cancer Biol, 15:33-42. Citado na pág. 91

Gorgoulis et al. (2002) V. G. Gorgoulis, P. Zacharatos e G. Mariatos. Transcription factor e2f1 acts as a growth-promoting factor and is associated with adverse prognosis in non-small cell lung carcinomas. J. Pathol, 198:142-156. Citado na pág. 107

Gregoire et al. (1995) L. Gregoire, A. L. Cubilla, V. E. Reuter, G. P. Haas e W. D. Lancaster. Preferential association of human papillomavirus with high-grade histologic variants of penileinvasive squamous cell carcinoma. J. Natl Cancer Inst, 87:1705-1709. Citado na pág. 19

Gribov et al. (2010) A. Gribov, M. Sill, S. Luck, F. Rucker, K. Dohner, L. Bullinger, A. Benner e A. Unwin. Seurat: visual analytics for the integrated analysis of microarray data. BMC Med Genomics, 3:21. Citado na pág. 7

Guimaraes et al. (2006) G. C. Guimaraes, A. Lopes, R. S. Campos, S. C. Zequi, M. L. Leal, A. L. Carvalho, I. W. da Cunha e F. A. Soares. Front pattern of invasion in squamous cell carcinoma of the penis: new prognostic factor for predicting risk of lymph node metastases. Urology, 68(1):148-153. Citado na pág. 107

Guimaraes et al. (2009) G. C. Guimaraes, I. W. Cunha, F. A. Soares, A. Lopes, J. Torres, A. Chaux, E. F. Velazquez, G. Ayala e A. L. Cubilla. Penile squamous cell carcinoma clinicopathological features and nodal metastasis and outcome in 333 cases. J. Urol, 182(2):528-34. Citado na pág. 17 
Guimaraes et al. (2011) G. C. Guimaraes, R. M. Rocha, S. C. Zequi, I. W. Cunha e F. A. Soares. Penile cancer: epidemiology and treatment. Curr Oncol Rep, 13(3):231-239. Citado na pág. 17,18

Gupta et al. (2009) R. K. Gupta, S. Meachum, I. Hernandez-Ochoa, J. Peretz, H. H. Yao e J. A. Flaws. Methoxychlor inhibits growth of antral follicles by altering cell cycle regulators. Toxicol Appl Pharmacol, 240(1):1-7. Citado na pág. 108

Haber et al. (1990) D. A. Haber, A. J. Buckler, T. Glaser, K. M. Call, J. Pelletier, R. L. Sohn, E. C. Douglass e D. E. Housman. An internal deletion within an $11 \mathrm{p} 13$ zinc finger gene contributes to the development of wilms' tumor. Cell, 61:1257-1269. Citado na pág. 88

Hagenbuchner et al. (2012) A. Hagenbuchner, V. Kuznetsov, P. Obexer e M. J. Ausserlechner. Birc5/survivin enhances aerobic glycolysis and drug resistance by altered regulation of the mitochondrial fusion/fission machinery. Oncogene, 32(40):4748-4757. Citado na pág. 98

Hah et al. (2013) J. H. Hah, M. Zhao, C. R. Pickering, M. J. Frederick, G. A. Andrews, S. A. Jasser, D. R. Fooshee, Z. L. Milas, C. Galer, D. Sano e et al. Hras mutations and resistance to the epidermal growth factor receptor tyrosine kinase inhibitor erlotinib in head and neck squamous cell carcinoma cells. Head $\&$ Neck. Citado na pág. 100

Hahn e Kern (2005) M. W. Hahn e A. D. Kern. Comparative genomics of centrality and essentiality in three eukaryotic protein-interaction networks. Mol Biol Evol, 22(4):803-806. Citado na pág. 100

Hao et al. (2008) Y. Hao, A. Chun, K. Cheung, B. Rashidi e X. Yang. Tumor suppressor lats1 is a negative regulator of oncogene yap. J. Biol Chem, 283:5496-5509. Citado na pág. 89

Harley et al. (1994) V. R. Harley, R. Lovell-Badge e P. N. Goodfellow. Definition of a consensus dna binding site for sry. Nucleic Acids Res, 22:1500-1501. Citado na pág. 106

He et al. (2013) S. L. He, W. H. Tan, Z. T. Zhang, F. Zhang, C. J. Qu, Y. X. Lei, Y. H. Zhu, H. J. Yu, Y. Z. Xiang e X. Guo. Mitochondrial-related gene expression profiles suggest an important role of pgc-1alpha in the compensatory mechanism of endemic dilated cardiomyopathy. Exp Cell Res, 319(17):2604-2616. Citado na pág. 88

He et al. (2012) W. He, Q. Wang, J. Xu, X. Xu, M. T. Padilla, G. Ren, X. Gou e Y. Lin. Attenuation of tnfsf10/trail-induced apoptosis by an autophagic survival pathway involving traf2 and ripk1/rip1-mediated mapk8/jnk activation. Autophagy, 8(12):1811-1821. Citado na pág. 94

Hernandez-Patino et al. (2013) C. E. Hernandez-Patino, G. Jaime-Munoz e O. ResendisAntonio. Systems biology of cancer: moving toward the integrative study of the metabolic alterations in cancer cells. Front Physiol, 3:481. Citado na pág. 2

Heselmeyer et al. (1996) K. Heselmeyer, E. Schrock, S. du Manoir, H. Blegen, K. Shah, R. Steinbeck, G. Auer e T. Ried. Gain of chromosome 3q defines the transition from severe dysplasia to invasive carcinoma of the uterine cervix. Proc Natl Acad Sci USA, 93(1):479-484. Citado na pág. 91

Heselmeyer et al. (1997) K. Heselmeyer, M. Macville, E. Schrock, H. Blegen, A. C. Hellstrom, K. Shah, G. Auer e T. Ried. Advanced-stage cervical carcinomas are defined by a recurrent pattern of chromosomal aberrations revealing high genetic instability and a consistent gain of chromosome arm 3q. Genes Chromosomes Cancer, 19(4):233-240. Citado na pág. 91

Hirata et al. (2012) H. Hirata, K. Ueno, V. Shahryari, Y. Tanaka, Z. L. Tabatabai, Y. Hinoda e R. Dahiya. Oncogenic mirna-182-5p targets smad4 and reck in human bladder cancer. PLoS ONE, 7(11):e51056. Citado na pág. 6 
H.Lu et al. (2010) H.Lu, M. Gan, G. Zhang, T. Zhou, M. Yan e S. Wang. Expression of survivin and caspase- 3 and p53 in cervical cancer assessed by tissue microarray: correlation with clinicopathology and prognosis. Eur J. Gynaecol Oncol, 31(6):662-666. Citado na pág. 98

Hodis et al. (2013) E. Hodis, I. R. Watson, G. V. Kryukov, S. T. Arold, M. Imielinski, J. P. Theurillat, E. Nickerson, D. Auclair, L. Li, C. Place e et al. A landscape of driver mutations in melanoma. Cell, 150(2):251-263. Citado na pág. 98

Hoesel e Schmid (2013) B. Hoesel e J. A. Schmid. The complexity of nf-kappa $\beta$ signaling in inflammation and cancer. Molecular Cancer, 12:86. Citado na pág. 99

Holland et al. (2013) J. D. Holland, A. Klaus, A. N. Garratt e W. Birchmeier. Wnt signaling in stem and cancer stem cells. Curr Opin Cell Biol, 25(2):254-264. Citado na pág. 99

Horenblas (2001) S. Horenblas. Lymphadenectomy for squamous cell carcinoma of the penis. part 2: the role and technique of lymph node dissection. BJU Int, 88:473-483. Citado na pág. 17

Huang et al. (2012) T. Huang, M. Jiang, X. Kong e Y. D. Cai. Dysfunctions associated with methylation and microrna expression and gene expression in lung cancer. PLoS ONE, 7(8): e43441. Citado na pág. 6

Hupe et al. (2004) P. Hupe, N. Stransky, J. P. Thiery, F. Radvanyi e E. Barillot. Analysis of array cgh data: from signal ratio to gain and loss of dna regions. Bioinformatics, 20(18): 3413-3422. Citado na pág. 33

Hupe et al. (2007) P. Hupe, P. La Rosa, S. Liva, S. Lair, N. Servant e E. Barillot. Actudb and a new database for the integrated analysis of array-cgh and clinical data for tumors. Oncogene, 26(46):6641-6652. Citado na pág. 7

Hwang e Shroyer (2012) S. J. Hwang e K. R. Shroyer. Biomarkers of cervical dysplasia and carcinoma. Journal of Oncology, 2012:507286. Citado na pág. 18

Jain et al. (2000) A. K. Jain, R. P. W. Duin e J. Mao. Statistical pattern recognition: A. review. IEEE TPAMI, 22(1):4-37. Citado na pág. 16

Jemal et al. (2007) A. Jemal, R. Siegel, E. Ward, T. Murray, J. Xu e M. J. Thun. Cancer statistics. CA Cancer J. Clin, 57:43-66. Citado na pág. 16

Jeon e Lambert (1995) S. Jeon e P. F. Lambert. Integration of human papillomavirus type 16 dna into the human genome leads to increased stability of e. 6 and e. 7 mrnas: Implications for cervical carcinogenesis. Proc. Natl. Acad. Sci. USA, 92:1654-1658. Citado na pág. 18

Jeong et al. (2000) H. Jeong, B. Tombor, R. Albert, Z. N. Oltvai e A. L. Barabasi. The large-scale organization of metabolic networks. Nature, 407:651-654. Citado na pág. 13

Jeong et al. (2001) H. Jeong, S. P. Mason, A. L. Barabasi e Z. N. Oltvai. Lethality and centrality in protein networks. Nature, 411(6833):41-42. Citado na pág. 100

Jia et al. (2010) Y. Jia, Y. Yang, S. Liu, J. G. Herman, F. Lu e M. Guo. Sox17 antagonizes wnt / $\beta$-catenin signaling pathway in hepatocellular carcinoma. Epigenetics, 5(8):743-749. Citado na pág. 96

Jia et al. (2012) Y. Jia, Y. Yang, Q. Zhan, M. V. X., Zheng, Y. Yu, J. G. Herman e M. Guo. Inhibition of sox17 by microrna 141 and methylation activates the wnt signaling pathway in esophageal cancer. J. MolDiagn, 14(6):577-585. Citado na pág. 6, 96

Johnson et al. (2005) S. M. Johnson, H. Grosshans, J. Shingara, M. Byrom, R. Jarvis, A. Cheng, E. Labourier, K. L. Reinert, D. Brown e F. J. Slack. Ras is regulated by the let-7 microrna family. Cell, 120:635-647. Citado na pág. 6, 99 
Jones et al. (1997) D. L. Jones, R. M. Alani e K. Munger. The human papillomavirus e. 7 oncoprotein can uncouple cellular differentiation and proliferation in human keratinocytes by abrogating p21cip1-mediated inhibition of cdk2. Genes Dev, 11:2101-2111. Citado na pág. 107

Jones e Baylin (2002) P. Jones e S. Baylin. The fundamental role of epigenetic events in cancer. Nat Genet, 3:415-428. Citado na pág. 82

Jones (2012) P. A. Jones. Functions of dna methylation: islands and start sites and gene bodies and beyond. Nat Rev Genet, 13(7):484-492. Citado na pág. 5

Jovov et al. (2012) B. Jovov, F. Araujo-Perez, C. S. Sigel, J. K. Stratford, A. N. McCoy, J. J. Yeh e T. Keku. Differential gene expression between african american and european american colorectal cancer patients. PLoS One, 7(1):e30168. Citado na pág. 88

Joy et al. (2005) M. P. Joy, A. Brock, D. E. Ingber e S. Huang. High-betweenness proteins in the yeast protein interaction network. J. Biomed Biotechnol, 2:96-103. Citado na pág. 100, 101

Jung et al. (2005) T. I. Jung, W. K. Baek, S. I. Suh, B. C. Jang, D. K. Song, J. H. Bae, K. Y. Kwon, J. H. Bae, S. D. Cha, I. Bae e C. H. Cho. Down-regulation of peroxisome proliferatoractivated receptor gamma in human cervical carcinoma. Gynecol Oncol, 97(2):365-373. Citado na pág. 93

Kalantari et al. (2001) M. Kalantari, E. Blennow, B. Hagmar e B. Johansson. Physical state of hpv16 and chromosomal mapping of the integrated form in cervical carcinomas. Diagn Mol Pathol, 10:46-54. Citado na pág. 18

Kalari e Pfeifer (2010) S. Kalari e G. P. Pfeifer. Identification of driver and passenger dna methylation in cancer by epigenomic analysis. Adv Genet, 70:277-308. Citado na pág. 82

Kalie et al. (2008) E. Kalie, D. A Jaitin, Y. Podoplelova, J. Piehler e G. Schreiber. The stability of the ternary interferon-receptor complex rather than the affinity to the individual subunits dictates differential biological activities. J. Biol Chem, 283:32925-32936. Citado na pág. 89

Kalra e Bapat (2013) R. S. Kalra e S. A. Bapat. Expression proteomics predicts loss of rxr- $\gamma$ during progression of epithelial ovarian cancer. PLoS One, 8(8):e70398. Citado na pág. 99

Kamb et al. (1994) A. Kamb, N. A. Gruis e J. Weaver-Feldhaus. A cell cycle regulator potentially involved in genesis of many tumor types. Science, 264:436-440. Citado na pág. 88

Kaminskyy et al. (2013) V. O. Kaminskyy, O. V. Surova, T. Piskunova, B. Zborovskaya, E. M. Tchevkina, L. Andera e B. Zhivotovsky. Upregulation of c-flip-short in response to trail promotes survival of nsclc cells and which could be suppressed by inhibition of ca2+/calmodulin signaling. Cell Death Dis, 4(3):e522. Citado na pág. 94

Kanungo et al. (2011) S. Kanungo, G. Sahoo e M. M. Gore. Bicross: A biclustering technique for gene expression data using one layer fixed weighted bipartite graph crossing minimization. IJCA Journal, 29(4):28-34. Citado na pág. 28

Karachaliou et al. (2013) N. Karachaliou, R. Rosell e S. Viteri. The role of sox2 in small cell lung cancer and lung adenocarcinoma and squamous cell carcinoma of the lung. TLCR, 2(3): 172-179. Citado na pág. 106

Kaufman et al. (2008) R. J. Kaufman, F. W. Alt e R. F. Kellems. Gene amplification and drug resistance in cultured murine cells. Science, 202:1051-1055. Citado na pág. 102

Khuri et al. (2000) F. R. Khuri, R. Lotan, B. L. Kemp, S. M. Lippman, H. Wu, L. Feng, J. J. Lee, C. S. Cooksley, B. Parr e E. Chang. Retinoic acid receptor-beta as a prognostic indicator in stage i. non-small-cell lung cancer. J. Clin Oncol, 18:2798-2804. Citado na pág. 95 
Knauer et al. (2013) S. K. Knauer, B. Unruhe, S. Karczewski, R. Hecht, V. Fetz, C. Bier, S. Friedl, B. Wollenberg, R. Pries, N. Habtemichael, U. R. Heinrich e R. H. Stauber. Functional characterization of novel mutations affecting survivin (birc5)-mediated therapy resistance in head and neck cancer patients. Hum Mutat, 34(2):395-404. Citado na pág. 98

Koh et al. (2012) S. C. Koh, C. Y. Huak, D. Lutan, J. Marpuang, S. Ketut, N. G. Budiana, A. Z. Saleh, M. F. Aziz, H. Winarto e H. Pradjatmo. Combined panel of serum human tissue kallikreins and ca-125 for the detection of epithelial ovarian cancer. J. Gynecol Oncol, 23(3): 175-181. Citado na pág. 109

Koller e Pfeffer (1997) D. Koller e A. Pfeffer. Object-oriented bayesian networks. In Proceedings Thirteenth Conference on Uncertainty in Artificial Intelligence, páginas 302-313. Citado na pág. 14

Koller e Pfeffer (1998) D. Koller e A. Pfeffer. Probabilistic frame-based systems. In Proceedings National Conference on Artificial Intelligence (AAAI), páginas 580-587. Citado na pág. 14

Konishi et al. (2009) K. Konishi, K. F. Gibson, K. O. Lindell, T. J. Richards, Y. Zhang, R. Dhir, M. Bisceglia, S. Gilbert, S. A. Yousem, J. W. Song, D. S. Kim e N. Kaminski. Gene expression profiles of acute exacerbations of idiopathic pulmonary fibrosis. Am J. Respir Crit Care Med, 180(2):167-175. Citado na pág. 89

Kononen e Palmberg (1997) J. Kononen e C. Palmberg. Androgen recep-tor gene amplification: a possible molecular mechanism forandrogen deprivation therapy failure in prostate cancer. Cancer Res, 57:314-319. Citado na pág. 5

Kreuter et al. (2010) A. Kreuter, M. Jesse, A. Potthoff, N. H. Brockmeyer, T. Gambichler, M. Stucker, F. G. Bechara, H. Pfister e U. Wieland. Expression of proliferative biomarkers in anal intraepithelial neoplasia of hiv-positive men. J. Am Acad Dermatol, 63:490-498. Citado na pág. 107

Kroon et al. (2008) B. K. Kroon, J. A. Leijte e H. van Boven. Microarray gene-expression profiling to predict lymph node metastasis in penile carcinoma. BJU Int, 102:510-515. Citado na pág. 17,21

Kuasne et al. (2013) H. Kuasne, F. A. Marchi, S. R. Rogatto e de I. M. Syllos-Colus. Epigenetic mechanisms in penile carcinoma. Int J. Mol Sci, 14(6):10791-808. Citado na pág. 17, 90

Kuijjer et al. (2012) M. L. Kuijjer, H. Rydbeck, S. H. Kresse, E. P. Buddingh, A. B. Lid, H. Roelofs, H. Burger, O. Myklebost, P. C. Hogendoorn e et al. Identification of osteosarcoma driver genes by integrative analysis of copy number and gene expression data. Genes Chromosomes Cancer, 51(7):696-706. Citado na pág. 82

Kumar et al. (2013) V. Kumar, V. Mundra e R. I. Mahato. Nanomedicines of hedgehog inhibitor and ppar- $\gamma$ agonist for treating liver fibrosis. Pharm Res. Citado na pág. 100

Kundu e Surh (2012) J. K. Kundu e Y. J. Surh. Emerging avenues linking inflammation and cancer. Free Radic Biol Med, 52(9):2013-2037. Citado na pág. 93

Kutalik et al. (2008) Z. Kutalik, J. S. Beckmann e S. Bergmann. A modular approach for integrative analysis of large-scale gene-expression and drug-response data. Nature Biotechnology, 26:531-539. Citado na pág. 4

Kyoko e Keisuke (2013) I. Kyoko e I. Keisuke. Newly identified roles of pml in stem cell biology. Front Oncol, 3:50. Citado na pág. 95 
Lacombe e Hannon (1995) L. Lacombe e G. J. Hannon. Deletion of the p16and p15 genes in human bladder tumors. J. Natl Cancer Inst, 87:1524-1529. Citado na pág. 5

Lee et al. (2013) C. Lee, Q. Zhang, J. Kozlowski, C. Brendler, B. M. Soares, A. Dash, M. McClelland e D. Mercola. Natural products and transforming growth factor-beta ( $\operatorname{tgf}-\beta$ ) signaling in cancer development and progression. Curr Cancer Drug Targets, 13(5):500-505. Citado na pág. 99

Lee e Kim (2009) M. Lee e Y. Kim. Chess (cghexpress): a comprehensive analysis tool for the analysis of genomic alterations and their effects on the expression profile of the genome. $B M C$ Bioinformatics, 10:424. Citado na pág. 7

Leis et al. (1998) P. F. Leis, K. R. Stevens, S. C. Baer, D. Kadmon, L. H. Goldberg e X. J. Wang. Ac-rasha mutation in the metastasis of a human papillomavirus (hpv)-18 positive penile squamous cell carcinoma suggests a cooperative effect between hpv-18 and c-rashaactivation in malignant progression. Cancer, 83:122-129. Citado na pág. 18

Li et al. (2011) B. Li, B. Wang, L. J. Niu, L. Jiang e C. C. Qiu. Hypermethylation of multiple tumor-related genes associated with dmnt3b upregulation served as a biomarker for early diagnosis of esophageal squamous cell carcinoma. Epigenetics, 6(3):307-316. Citado na pág. 97

Li et al. (1997) J. Li, C. Yen, D. Liaw, K. Podsypanina, S. Bose, S. I. Wang, J. Puc, C. Miliaresis, L. Rodgers e R. McCombie. Pten and a putative protein tyrosinephosphatase gene mutated in human brain and breast and andprostate cancer. Science, 275:1943-1947. Citado na pág. 5

Li et al. (2013) J. Li, L. Du, Y. Yang, C. Wang, H. Liu, L. Wang, X. Zhang, W. Li, G. Zheng e Z. Dong. Mir-429 is an independent prognostic factor in colorectal cancer and exerts its anti-apoptotic function by targeting sox2. Cancer Lett, 329(1):84-90. Citado na pág. 92

Li et al. (2012a) J. Y. Li, C. Han, L. L. Zheng e M. Z. Guo. Epigenetic regulation of wnt signaling pathway gene sry-related hmg-box 17 in papillary thyroid carcinoma. Chin Med J. (Engl), 125(19):3526-3531. Citado na pág. 81, 96

Li et al. (2012b) S. X. Li, L. Chai, Z. G. Cai, L. J. Jin, Y. Chen, H. R. Wu e Z. Sun. Expression of survivin and caspase 3 in oral squamous cell carcinoma and peritumoral tissue. Asian Pac J. Cancer Prev, 13(10):5027-5031. Citado na pág. 98

Liao e Lo (2008) Y. C. Liao e S. H. Lo. Deleted in liver cancer-1 (dlc-1): a tumor suppressor not just for liver. Int J. Biochem Cell Biol, 40(5):843-847. Citado na pág. 92

Litjens et al. (2013) R. J. Litjens, A. H. Hopman, K. K. van de Vijver, F. C. Ramaekers, R. F. Kruitwagen e A. J. Kruse. Molecular biomarkers in cervical cancer diagnosis: a critical appraisal. Expert Opin Med Diagn, 7(4):365-377. Citado na pág. 105

Litvin et al. (2009) O. Litvin, H. Causton, B. J. Chen e D. Pe'er. Modularity and interactions in the genetics of gene expression. Proc Natl Acad Sci., 106(16):6441-6446. Citado na pág. 3

Liu et al. (2012) C. J. Liu, S. C. Lin, C. C. Yang, H. W. Cheng e K. W. Chang. Exploiting salivary mir-31 as a clinical biomarker of oral squamous cell carcinoma. Head Neck, 34(2): 219-224. Citado na pág. 97

Liu et al. (2013) L. Liu, Y. Ma, R. L. Wang, W. R. Xu, S. Q. Wang e K. C. Chou. Find novel dual-agonist drugs for treating type 2 diabetes by means of cheminformatics. Drug Des Devel Ther, 7:279-288. Citado na pág. 100, 106

Liu et al. (2007) Y. Liu, M. Asakura, H. Inoue, T. Nakamura, M. Sano, Z. Niu, M. Chen, R. J. Schwartz e M. D. Schneider. Sox17 is essential for the specification of cardiac mesoderm in embryonic stem cells. Proc Natl Acad Sci USA, 104(10):3859-3864. Citado na pág. 96 
Lo-Muzio et al. (2001) L. Lo-Muzio, S. Staibano, G. Pannone, M. D. Mignogna, A. Mariggio, G. Salvatore, P. Chieffi, D. Tramontano, G. De Rosa e D. C. Altieri. Expression of the apoptosis inhibitor survivin in aggressive squamous cell carcinoma. Exp Mol Pathol, 70(3):249-254. Citado na pág. 98

Loebinger et al. (2010) M. R. Loebinger, E. K. Sage, D. Davies e S. M. Janes. Trail-expressing mesenchymal stem cells kill the putative cancer stem cell population. Br J. Cancer, 103(11): 1692-1697. Citado na pág. 94

Lohavanichbutr et al. (2010) P. Lohavanichbutr, J. Houck, W. Fan, B. Yueh, E. Mendez, N. Futran, D. R. Doody e et al. Genome-wide gene expression profiles of hpv-positive and hpvnegative oropharyngeal cancer: potential implications for treatment choices. Arch Otolaryngol Head Neck Surg, 135(2):180-188. Citado na pág. 108

Lont et al. (2006) A. P Lont, B. K Kroon e S. Horenblas. Presence of high-risk human papillomavirus dna in penile carcinoma predicts favorable outcome in survival. Int J. Cancer, 119: 1078-81. Citado na pág. 19

Lopes et al. (2002) A. Lopes, A. L. Bezerra, C. A. Pinto, S. V. Serrano, C. A. de Mello e L. L. Villa. p53 as a new prognostic factor for lymph node metastasis in penile carcinoma: analysis of82 patients treated with amputation and bilateral lymphadenectomy. J. Urol, 168:81-86. Citado na pág. 107

Lopes (2011) Fabricio Martins Lopes. Redes complexas de expressao gênica. Phd in bioinformatics, Instituto de Matematica e Estatistica-Universidade de Sao Paulo. Citado na pág. 16

Lou et al. (2011) J. Lou, J. Xue e Q. Lin. Transcriptome-wide network analysis of squamous lung cancer reveals potential methylation genes. Asian Pac J. Cancer Prev, 12(9):2349-2352. Citado na pág. 81

Louhimo e Hautaniemi (2011) R. Louhimo e S. Hautaniemi. Cnamet: an r. package for integrating copy number and methylation and expression data. Bioinformatics, 27(6):887888. Citado na pág. 8

Lu et al. (2012) D. Lu, J. Qian, X. Yin, Q. Xiao, C. Wang e Y. Zeng. Expression of pten and survivin in cervical cancer: promising biological markers for early diagnosis and prognostic evaluation. Br J. Biomed Sci, 69(4):143-146. Citado na pág. 98

Lu et al. (2005) J. Lu, G. Getz, E. A. Miska, E. Alvarez-Saavedra, J. Lamb, D. Peck, A. SweetCordero, B. L. Ebert, R. H. Mak, A. A. Ferrando e et al. Microrna expression profiles classify human cancers. Nature, 435:834-838. Citado na pág. 6

Lukusa e Fryns (2008) T. Lukusa e J. P. Fryns. Human chromosome fragility. Biochim Biophys Acta, 1779:3-16. Citado na pág. 91

Luo et al. (2001) L. Y. Luo, E. R., Jung K. e E. P. Diamandis. Expression of the normal epithelial cell-specific 1 (nes1, klk10) candidate tumour suppressor gene in normal and malignant testicular tissue. Br J. Cancer, 85:220-224. Citado na pág. 105

Maire et al. (2012) A. L. Maire, S. Alvarez, P. Shankaranarayanan, A. R. Lera, W. Bourguet e H. Gronemeyer. Retinoid receptors and therapeutic applications of rar/rxr modulators. Curr Top Med Chem, 12:505-527. Citado na pág. 99

Malumbres (2012) M. Malumbres. mirnas versus oncogenes: the power of social networking. Molecular Systems Biology, 8:569. Citado na pág. 6

Marshall (2001) R. J. Marshall. The use of classification and regression trees in clinical epidemiology. J. Clin Epidemiol, 54(6):603-609. Citado na pág. 28 
Martin et al. (2008) C. L. Martin, S. C. Reshmi, T. Ried, W.G ottberg, J. W. Wilson, J. K. Reddy, P. Khanna, J. T. Johnson, E. N. Myers e S. M. Gollin. Chromosomal imbalances in oral squamous cell carcinoma. Oral Oncol, 44(4):369-382. Citado na pág. 90

Martinez-Pacheco et al. (2014) M. Martinez-Pacheco, A. Hidalgo-Miranda, S. RomeroCordoba, M. Valverde e E. Rojas. mrna and mirna expression patterns associated to pathways linked to metal mixture health effects. Gene, 533(2):508-514. Citado na pág. 89

Martins et al. (2002) A. C. Martins, S. M. Faria, A. J. Cologna, H. J. Suaid e S. Tucci. Immunoexpression of p53 protein and proliferating cell nuclear antigen in penile carcinoma. $J$ Urol, 167(1):89-92. Citado na pág. 107

Mathias et al. (2013) R. A. Mathias, S. K. Gopal e R. J. Simpson. Contribution of cells undergoing epithelial-mesenchymal transition to the tumour microenvironment. J. Proteomics, 78:545-557. Citado na pág. 95

Mattsson et al. (2008) J. M. Mattsson, P. Laakkonen, S. Kilpinen, U. H. Stenman e H. Koistinen. Gene expression changes associated with the anti-angiogenic activity of kallikrein-related peptidase (klk3) on human umbilical vein endothelial cells. Biol Chem, 389:765-771. Citado na pág. 89

McDonald et al. (2013) M. K. McDonald, K. E. Capasso e S. K. Ajit. Purification and microrna profiling of exosomes derived from blood and culture media. J. Vis Exp, 76:e50294. Citado na pág. 89

McFarland et al. (2013) C. D. McFarland, K. S. Korolev, G. V. Kryukov, S. R. Sunyaev e L. A. Mirny. Impact of deleterious passenger mutations on cancer progression. PNAS. Citado na pág. 20,83

Melendy et al. (1995) T. Melendy, J. Sedman e A. Stenlund. Cellular factors required for papillomavirus dna replication. J. Virol, 69:7857-7867. Citado na pág. 107

Mertin et al. (1999) S. Mertin, S. G. McDowall e V. R. Harley. The dna-binding specificity of sox9 and other sox proteins. Nucleic Acids Res, 27:1359-1364. Citado na pág. 106

Michoel et al. (2007) T. Michoel, S. Maere, E. Bonnet, A. Joshi, Y. Saeys, T. Van den Bulcke, K. Van-Leemput, P. van Remortel, M. Kuiper e K. Marchal. Validating module network learning algorithms using simulated data. BMC Bioinformatics, 8:S5. Citado na pág. , 26, 42, 77, $78,85,86,111$

Miralles-Guri et al. (2009) C. Miralles-Guri, L. Bruni, A. L. Cubilla, X. Castellsague, F. X. Bosch e S. Sanjose. Human papillomavirus prevalence and type distribution in penile carcinoma. J. Clin Pathol, 62:870-878. Citado na pág. 18, 102

Missaoui et al. (2011) N. Missaoui, S. Hmissa, A. Trabelsi, C. Traore, M. Mokni, R. Dante e L. Frappart. Promoter hypermethylation of cdh13 and dapk1 and twist1 genes in precancerous and cancerous lesions of the uterine cervix. Pathol Res Pract, 207:37-42. Citado na pág. 96

Moncho-Amor et al. (2011) V. Moncho-Amor, I. I. Caceres, E. Bandres, B. Martinez-Poveda, J. L. Orgaz, I. Sanchez-Perez, S. Zazo, A. Rovira, J. Albanell e B. Jimenez. Dusp1/mkp1 promotes angiogenesis and invasion and metastasis in non-small-cell lung cancer. Oncogene, 30(6):668-678. Citado na pág. 104

Moody et al. (2005) J. Moody, D. McFarland e S. Bender-deMoll. Dynamic network visualization. American Journal of Sociology, 110(4):1206-1241. Citado na pág. 12 
Morris et al. (2012) A. P. Morris, B. F. Voight, T. M. Teslovich, T. Ferreira, A. V. Segre, V. Steinthorsdottir, R. J. Strawbridge, H. Khan, H. Grallert e A. Mahajan. Diabetes genetics replication and meta-analysis (diagram) consortium. large-scale association analysis provides insights into the genetic architecture and pathophysiology of type 2 diabetes. Nat Genet, 44 (9):981-990. Citado na pág. 4

Mosconi et al. (2005) A. M. Mosconi, F. Roila, G. Gatta e C. Theodore. Cancer of the penis. Crit Rev Oncol Hematol, 53:165-177. Citado na pág. 17

Myga-Nowak et al. (2011) M. Myga-Nowak, J. Pacholska-Bogalska, W. Kwasniewski, A. Kwasniewska e A. Gozdzicka-Jozefiak. Proliferation of cells and expression of rars and rxrs and hpv viral e. 6 and e. 7 proteins in cervical cancer cell lines after treatment with atra. Ann Agric Environ Med, 18(1):145-150. Citado na pág. 103

Nadiminty et al. (2012) N. Nadiminty, R. Tummala, W. Lou, Y. Zhu, J. Zhang, X. Chen, R. W. eVere White, H. J. Kung, C. P. Evans e A. C. Gao. Microrna let-7c suppresses androgen receptor expression and activity via regulation of myc expression in prostate cancer cells. $J$. Biol Chem, 287(2):1527-1537. Citado na pág. 94

Nagai et al. (1994) M. A. Nagai, L. Yamamoto, S. Salaorni, M. M. Pacheco, M. M. Brentani, E. M. Barbosa, R. R. Brentani, S. Mazoyer, S. A. Smith, B. A. Ponder e et al. Detailed deletionmapping of chromosome segment 17q12-21 in sporadicbreast tumours. Genes Chromosomes Cancer, 11:58-62. Citado na pág. 5

Nalepa et al. (2013) G. Nalepa, J. Barnholtz-Sloan, R. Enzor, D. Dey, Y. He, J. R. Gehlhausen, A. S. Lehmann, S. J. Park, Y. Yang, X. Yang e et al. The tumor suppressor cdkn3 controls mitosis. J. Cell Biol, 201(7):997-1012. Citado na pág. 87

Naylor (1997) C. D. Naylor. Meta-analysis and the meta-epidemiology of clinical research. $B M J, 315(7109): 617-619$. Citado na pág. 90

Niculescu et al. (2004) M. D. Niculescu, Y. Yamamuro e S. H. Zeisel. Choline availability modulates human neuroblastoma cell proliferation and alters the methylation of the promoter region of the cyclin-dependent kinase inhibitor 3 gene. J. Neurochem, 89(5):1252-1259. Citado na pág. 87

O'Carroll e Schaefer (2013) D. O'Carroll e A. Schaefer. General principals of mirna biogenesis and regulation in the brain. Neuropsychopharmacology Reviews, 38:39-54. Citado na pág. 6

Ochoa-Hernandez et al. (2012) A. B. Ochoa-Hernandez, C. I. Juarez-Vazquez, M. A. Rosales e P. Barros-Nunez. Wnt- $\beta$-catenin signaling pathway and its relationship with cancer. Cir Cir, 80(4):389-398. Citado na pág. 106

Oishi et al. (2012) Y. Oishi, Y. Watanabe, Y. Yoshida, Y. Sato, T. Hiraishi, R. Oikawa, T. Maehata, H. Suzuki, M. Toyota e H. Niwa. Hypermethylation of sox17 gene is useful as a molecular diagnostic application in early gastric cancer. Tumour Biol, 33(2):383-393. Citado na pág. 96

Okada et al. (2010) T. Okada, Y. Suehiro, K. Ueno, S. Mitomori, S. Kaneko, M. Nishioka, N. Okayama, K. Sakai, S. Higaki, S. Hazama e et al. Twist1 hypermethylation is observed frequently in colorectal tumors and its overexpression is associated with unfavorable outcomes in patients with colorectal cancer. Genes Chromosomes Cancer, 49(5):452-462. Citado na pág. 96

Olshen et al. (2004) A. B. Olshen, E. S. Venkatraman, R. Lucito e M. Wigler. Circular binary segmentation for the analysis of array-based dna copy number data. Biostatistics, 5(4):557-572. Citado na pág. 8 
O’Reilly et al. (2006) K. E. O'Reilly, F. Rojo, Q. B. She, D. Solit, G. B. Mills, D. Smith, H. Lane, F. Hofmann, D. J. Hicklin, D. L. Ludwig, J. Baselga e N. Rosen. mtor inhibition induces upstream receptor tyrosine kinase signaling and activates akt. Cancer Res, 66:15001508. Citado na pág. 2

Pageand et al. (1999) L. Pageand, S. Brin, R. Motwani e T. Winograd. The pagerank citation ranking: Bringing order to the web. Technical Report 1999-66, Stanford InfoLab. Citado na pág. 100

Pappas et al. (2011) J. J. Pappas, A. Toulouse, M. Basik, L. Levesque e W. E. Bradley. Knockdown of rarb2 identifies a dual role in cancer. Genes Chromosomes Cancer, 50(9): 700-714. Citado na pág. 95

Parkin e Muir (1992) D. M. Parkin e C. S. Muir. Cancer incidence in five continents.comparability and quality of data. IARC Sci Publ, 120:45-173. Citado na pág. 16

Parsons et al. (2008) D. W. Parsons, S. Jones, X. Zhang, J. C. Lin, R. J. Leary, P. Angenendt, P. Mankoo, H. Carter, I. M. Siu, G. L. Gallia, A. Olivi e et al. An integrated genomic analysis of human glioblastoma multiforme. Science, 321:1807-1812. Citado na pág. 82

Pe'er (2005) D. Pe'er. Bayesian network analysis of signaling networks: a primer. Science, 281: p14. Citado na pág. 14

Pe'er e Hacohen (2011) D. Pe'er e N. Hacohen. Principles and strategies for developing network models in cancer. Cell, 144(6):864-873. Citado na pág. 2, 3

Pe'er et al. (2001) D. Pe'er, A. Regev, G. Elidan e N. Friedman. Inferring subnetworks from perturbed expression profiles. Bioinformatics, 17:S215-S.224. Citado na pág. 85

Pelosi et al. (2013) A. Pelosi, S. Careccia, V. Lulli, P. Romania, G. Marziali, U. Testa, S. Lavorgna, F. Lo-Coco, M. C. Petti, B. Calabretta e et al. mirna let-7c promotes granulocytic differentiation in acute myeloid leukemia. Oncogene, 32(31):3648-3654. Citado na pág. 94

Pennington e Dunn (2001) S. Pennington e M. J. Dunn. Proteomics: From Protein Sequence to Function, volume 1 of 1. Bios Scientific, 1 ed. ISBN 1859962963. Citado na pág. 87

Pettus et al. (2009) J. R. Pettus, J. J. Johnson, Z. Shi, J. W. Davis, J. Koblinski, S. Ghosh, Y. Liu, M. J. Ravosa, S. Frazier e M. S. Stack. Multiple kallikrein (klk 5 and 7 and 8 and and 10) expression in squamous cell carcinoma of the oral cavity. Histol Histopathol, 24(2): 197-207. Citado na pág. 105

Pickering et al. (2013) C. R. Pickering, J. Zhang, S. Y. Yoo, L. Bengtsson, S. Moorthy, D. M. Neskey, M. Zhao, M. V. O. Alves, K. Chang, J. Drummond, E. Cortez e et al. Integrative genomic characterization of oral squamous cell carcinoma identifies frequent somatic drivers. Cancer Discovery, 3(11):770. Citado na pág. 100

Piepoli et al. (2012) A. Piepoli, F. Tavano, M. Copetti, T. Mazza e O. Palumbo. Mirna expression profiles identify drivers in colorectal and pancreatic cancers. PLoS ONE, 7(3): e33663. Citado na pág. 82

Pike et al. (2008) B. L. Pike, T. C. Greiner, X. Wang, D. D. Weisenburger, Y. H. Hsu, G. Renaud e et al. Dna methylation profiles in diffuse large b-cell lymphoma and their relationship to gene expression status. Leukemia, 22:1035-1043. Citado na pág. 92

Planque et al. (2006) C. Planque, M. AÃ́rnciburu, N. Heuze-Vourc'h, S. Regina, de M. Monte e Y. Courty. Expression of the human kallikrein genes 10 (klk10) and 11 (klk11) in cancerous and non-cancerous lung tissues. Biol Chem, 387(6):783-788. Citado na pág. 105 
Pollack et al. (2002) J. R. Pollack, T. Sorlie, C. M. Perou, C. A. Rees, S. S. Jeffrey, P. E. Lonning, R. Tibshirani, D. Botstein e A. L. Borresen-Dale. Brown microarray analysis reveals a major direct role of dna copy number alteration in the transcriptional program of human breast tumors. Proc. Natl Acad. Sci, 99:12963-12968. Citado na pág. 8, 81

Poulikakos et al. (2010) P. I. Poulikakos, C. Zhang, G. Bollag, K. M. Shokat e N. Rosen. Raf inhibitors transactivate raf dimers and erk signalling in cells with wild-type braf. Nature, 464: 427-430. Citado na pág. 3

Pritchard et al. (2012) C. C. Pritchard, H. H. Cheng e M. Tewari. Microrna profiling: approaches and considerations. Nature Genetics, 13:358-369. Citado na pág. 5

Protzel et al. (2007) C. Protzel, J. Knoedel, U. Zimmermann, C. Woenckhaus, M. Poetsch e J. Giebel. Expression of proliferation marker ki67 correlates to occurrence of metastasis and prognosis and histological subtypes and hpv dna detection in penile carcinomas. Histol Histopathol, 22:1197-204. Citado na pág. 107

Prowse et al. (2008) D. M. Prowse, E. N. Ktori, D. Chandrasekaran, A. Prapa e S. Baithun. Human papillomavirus-associated increase in p16ink4a. expression in penile lichen sclerosus and squamous cell carcinoma. Br J. Dermatol, 158:261-265. Citado na pág. 108

Pycha et al. (1998) A. Pycha, C. Mian, B. Posch, A. Haitel, M. El-Baz, M. A. Ghoneim e M. Marberger. Numerical aberrations of chromosomes 7 and 9 and 17 in squamous cell and transitional cell cancer of the bladder: a comparative study performed by fluorescence in situ hybridization. J. Urol, 160(3):737-740. Citado na pág. 90

Qayum e Ashraf (2006) I. Qayum e M. Ashraf. Dna methyltransferase 1 (dnmt1) gene activity in human lymphomas correlates with aberrant p53 gene expression. J. Ayub Med Coll Abbottabad, 18(1):1-6. Citado na pág. 97

Redon et al. (2001) R. Redon, D. Muller, K. Caulee, K. Wanherdrick, J. Abecassis e S. du Manoir. A simple specific pattern of chromosomal aberrations at early stages of head and neck squamous cell carcinomas: Pik3ca but not p63 gene as a likely target of 3q26-qter gains. Cancer Res, 61:4122-4129. Citado na pág. 91

Remy et al. (2013) S. Remy, S. Verstraelen, R. Van Den Heuvel, I. Nelissen, N. Lambrechts, J. Hooyberghs e G. Schoeters. Gene expressions changes in bronchial epithelial cells: Markers for respiratory sensitizers and exploration of the nrf2 pathway. Toxicol In Vitro, 13:272-275. Citado na pág. 88

Robinson (2008) J. W. Robinson. Regression tree boosting to adjust health care cost predictions for diagnostic mix. Health Serv Res, 43(2):755-772. Citado na pág. 28

Romania et al. (2013) P. Romania, A. Castellano, C. Surace, A. Citti, M. A. De Ioris, P. Sirleto, M. De Mariano, L. Longo, R. Boldrini, A. Angioni, F. Locatelli e D. Fruci. High-resolution array cgh profiling identifies na/k transporting atpase interacting 2 (nkain2) as a predisposing candidate gene in neuroblastoma. PLoS One, 8(10):e78481. Citado na pág. 5

Rothenberg e Settleman (2010) S. M. Rothenberg e J. Settleman. Discovering tumor suppressor genes through genome-wide copy number analysis. Curr Genomics, 11(5):297-310. Citado na pág. 88

Rubin et al. (2001) M. A. Rubin, B. Kleter e M. Zhou. Detection and typing of human papillomavirus dna in penile carcinoma: evidence for multiple independent pathways of penile carcinogenesis. Am J. Pathol, 159:1211-1218. Citado na pág. 18, 103 
Ruivenkamp et al. (2002) C. A. Ruivenkamp, T. van Wezel, C. Zanon, A. P. Stassen, C. Vlcek, T. Csikos, A. M. Klous, N. Tripodis, A. Perrakis, L. Boerrigter e et al. Ptprj is acandidate for the mouse colon-cancer susceptibility locusscc 1 and is frequently deleted in human cancers. Nat Genet, 31:295-300. Citado na pág. 5

Russell e Norvig (1995) S. J Russell e P. Norvig. Artificial Intelligence: A. Modern Approach. Prentice Hall, Prentice Hall and Englewood Cliffs and New Jersey 07632, 1 ed. ISBN 0131038052. Citado na pág. 13

Sachs et al. (2005) K. Sachs, O. Perez, D. Pe'er, D. A. Lauffenburger e G. P. Nolan. Causal protein-signaling networks derived from multiparameter single-cell data. Science, 22:523-529. Citado na pág. 3

Salari et al. (2010) K. Salari, R. Tibshirani e J. R. Pollack. Dr-integrator: a new analytic tool for integrating dna copy number and gene expression data. Bioinformatics, 26(3):414-416. Citado na pág. 7

Santin et al. (2005) A. D. Santin, E. P. Diamandis, S. Bellone, A. Soosaipillai, S. Cane, M. Palmieri, A. Burnett, J. J. Roman e S. Pecorelli. Human kallikrein 6: a new potential serum biomarker for uterine serous papillary cancer. Clin Cancer Res, 11(9):3320-3325. Citado na pág. 105,107

Sarkar et al. (1992) F. H. Sarkar, B. J. Miles, D. H. Plieth e J. D. Crissman. Detection of human papillomavirus in squamous neoplasm of the penis. J. Urol, 147:389-392. Citado na pág. 18,108

Sassen et al. (2008) S. Sassen, E. A. Miska e C. Caldas. Microrna - implications for cancer. Virchows Arch, 452:1-10. Citado na pág. 6

Saumet et al. (2008) A. Saumet, G. Vetter, M. Bouttier, E. Portales-Casamar, W. W. Wasserman, T. Maurin, B. Mari, P. Barbry, L. Vallar, E. Friederich, K. Arar, B. Cassinat, C. Chomienne e C. H. Lecellier. Transcriptional repression of microrna genes by pml-rara increases expression of key cancer proteins in acute promyelocytic leukemia. Blood, 113(2):412-421. Citado na pág. 95

Schäfer et al. (2009) M. Schäfer, H. Schwender, S. Merk, C. Haferlach, K. Ickstadt e M. Dugas. Integrated analysis of copy number alterations and gene expression. Bioinformatics, 25(24): 3228-3235. Citado na pág. 8

Schwab e Lin (1983) M. Schwab e C. C. Lin. Homogeneouslystaining chromosomal regions contain amplified copies ofan abundantly expressed cellular oncogene (c-myc) inmalignant neuroendocrine cells from a human coloncarcinoma. Proc Natl Acad Sci USA, 26(80):17071711. Citado na pág. 5

Segal et al. (2003) E. Segal, M. Shapira, A. aRegev nd D. Pe'er, D. Botstein, D. Koller e N. Friedman. Module networks: identifying regulatory modules and their condition specific regulators from gene expression data. Nat Genet, 34:166-176. Citado na pág. , 3, 15, 26, 27, 30, $42,77,78,82,85,86,87,111$

Segal et al. (2005) E. Segal, N. Friedman, N. Kaminski, A. Regev e D. Koller. From signatures to models: understanding cancer using microarrays. Nat Genet, 37:S38-S45. Citado na pág. 27, 85

Sen-Yo et al. (2012) M. Sen-Yo, Y. Suehiro, S. Kaino e I. Sakaida. Twist1 hypermethylation is observed in pancreatic cancer. Biomedical Reports, 1:31-33. Citado na pág. 96 
Sharma et al. (2010) S. V. Sharma, D. A. Haber e J. Settleman. Cell line-based platforms to evaluate the therapeutic efficacy of candidate anticancer agents. Nat Rev Cancer, 10:241-253. Citado na pág. 3

Shen et al. (2009) R. Shen, A. B. Olshen e M. Ladanyi. Integrative clustering of multiple genomic data types using a joint latent variable model with application to breast and lung cancer subtype analysis. Bioinformatics, 25(22):2906-2912. Citado na pág. 6

Sheridan et al. (1997) J. P. Sheridan, S. A. Marsters e R. M. Pitti. Control of trail-induced apoptosis by a family of signaling and decoy receptors. Science, 277:818-821. Citado na pág. 94

Sherr (1994) C. J. Sherr. G. 1 phase progression: cycling on cue. Cell, 79:551-555. Citado na pág. 103

Shi et al. (2007) H. Shi, J. Guo, D. J. Duff, F. Rahmatpanah, R. Chitima-Matsiga, M. AlKuhlani, K. H. Taylor, O. Sjahputera, M. Andreski, J. E. Wooldridge e et al. Discovery of novel epigenetic markers in non-hodgkin's lymphoma. Carcinogenesis, 28:60-70. Citado na pág. 92

Shimazaki et al. (2008) N. Shimazaki, N. Togashi, M. Hanai, T. Isoyama, K. Wada, T. Fujita, K. Fujiwara e S. Kurakata. Anti-tumour activity of cs-7017 and a selective peroxisome proliferator-activated receptor gamma agonist of thiazolidinedione class and in human tumour xenografts and a syngeneic tumour implant model. Eur J. Cancer, 44(12):1734-1743. Citado na pág. 94

Shuangge et al. (2011) M. A. Shuangge, H. Jian e S. Xiao. Integrative analysis and variable selection with multiple high-dimensional data sets. Biostatistics, 12:763-775. Citado na pág. 1

Shukla et al. (2009) S. Shukla, A. C. Bharti e S. Mahata. Infection of human papillomaviruses in cancers of different human organ sites. Indian J. Med Res, 130:222-233. Citado na pág. 17

Silveira et al. (2009) C. G. Silveira, F. M. Oliveira, E. T. Valera, M. R. Ikoma, T. Borgonovo, I. J. Cavalli, L. G. Tone e S. R. Rogatto. New recurrent deletions in the ppargamma and tp53 genes are associated with childhood myelodysplastic syndrome. Leuk Res, 33(1):19-27. Citado na pág. 93

Singh et al. (2013) N. Singh, R. C. Sobti, V. Suri, R. Nijhawan, S. Sharma, B. C. Das, M. Bharadwaj e S. Hussain. Downregulation of tumor suppressor gene pml in uterine cervical carcinogenesis: impact of human papillomavirus infection (hpv). Gynecol Oncol, 128(3):420-426. Citado na pág. 95

Singhal et al. (2003) S. Singhal, K. M. Amin, R. Kruklitis, P. DeLong, M. E. Friscia, L. A. Litzky, M. E. Putt, L. R. Kaiser e S. M. Albelda. Alterations in cell cycle genes in early stage lung adenocarcinoma identified by expression profiling. Cancer Biol Ther, 2(3):291-298. Citado na pág. 107

Sjoblom et al. (2006) T. Sjoblom, S. Jones, L. D. Wood, D. W. Parsons, J. Lin, T. D. Barber, D. Mandelker, R. J. Leary, J. Ptak, N. Silliman e et al. The consensus coding sequences of human breast and colorectal cancers. Science, 314(5797):268-274. Citado na pág. 82

Slebos et al. (2006) R. J. Slebos, Y. Yi, K. Ely, J. Carter, A. Evjen, X. Zhang, Y. Shyr, B. M. Murphy, A. J. Cmelak, B. B. Burkey e et al. Gene expression differences associated with human papillomavirus status in head and neck squamous cell carcinoma. Clin Cancer Res, 12: 701-709. Citado na pág. 107

Smith et al. (1998) L. Smith, S. J. Liu, L. Goodrich, D. Jacobson, C. Degnin, N. Bentley, A. Carr, G. Flaggs, K. Keegan, M. Hoekstra e M. Thayer. Duplication of atr inhibits myod 
and induces aneuploidy and eliminates radiation-induced g. 1 arrest. Nat Genet, 19(1):39-46. Citado na pág. 91

Song et al. (2006) Y. F. Song, R. Xu, X. H. Zhang, B. B. Chen, Q. Chen, Y. M. Chen e Y. Xie. High-frequency promoter hypermethylation of the deleted in liver cancer-1 gene in multiple myeloma. J. Clin Pathol, 59(9):947-951. Citado na pág. 92

Sonkoly et al. (2012) E. Sonkoly, J. Loven, N. Xu, F. Meisgen, T. Wei, P. Brodin, V. Jaks, M. Kasper, T. Shimokawa e M. Harada. Microrna-203 functions as a tumor suppressor in basal cell carcinoma. J. Biol Chem, 288(3):1918-1928. Citado na pág. 6

Sonpavde et al. (2013) G. Sonpavde, L. C. Pagliaro, C. Buonerba, T. B. Dorff, R. J. Lee e G. Di Lorenzo. Penile cancer: current therapy and future directions. Ann Oncol, 24(5): 1179-89. Citado na pág. 16

Soria et al. (2000) J. C. Soria, S. J. Jang, F. R. Khuri, K. Hassan, D. Liu, W. K. Hong e L. Mao. Overexpression of cyclin b. 1 in early-stage non-small cell lung cancer and its clinical implication. Cancer Res, 60:4000-4004. Citado na pág. 107

Stankiewicz et al. (2009) E. Stankiewicz, S. C. Kudahetti e D. M. Prowse. Pv infection and immunochemical detection of cell-cycle markers in verrucous carcinoma of the penis. Mod Pathol, 22:1160-1168. Citado na pág. 103

Staples et al. (2011) C. J. Staples, D. M. Owens, J. V. Maier, A. C. B. Cato e S. M. Keyse. Cross-talk between the p381̂́s and jnk mapk pathways mediated by map kinase phosphatase-1 determines cellular sensitivity to uv radiation. J. Biol Chem, 286:17398. Citado na pág. 104

Stratton et al. (2009) M. R. Stratton, P. Campbell e P. Futreal. The cancer genome. Nature, 458:719-724. Citado na pág. 81

Su et al. (2010) L. Su, Y. Wang, M. Xiao, Y. Lin e L. Yu. Up-regulation of survivin in oral squamous cell carcinoma correlates with poor prognosis and chemoresistance. Oral Surg Oral Med Oral Pathol Oral Radiol Endod, 110(4):484-491. Citado na pág. 98

Sun e Zhao (2010) J. Sun e Z. Zhao. A comparative study of cancer proteins in the human protein-protein interaction network. BMC Genomics, 3:S5. Citado na pág. 108

Sun et al. (2012) J. Sun, J. Xiong, Y. Zhen, Z. L. Chen e H. Zhang. P53 and pcna is positively correlated with hpv infection in laryngeal epitheliopapillomatous lesions in patiets with different ethnic backgrounds in xinjiang. Asian Pac J Cancer Prev, 13(11):5439-5444. Citado na pág. 104

Takashima et al. (2005) T. Takashima, Y. Fujiwara, M. Hamaguchi, E. Sasaki, K. Tominaga, T. Watanabe, N. Oshitani, K. Higuchi e T. Arakawa. Relationship between peroxisome proliferator-activated receptor-gamma expression and differentiation of human esophageal squamous cell carcinoma. Oncol Rep, 13(4):601-606. Citado na pág. 93

Tam et al. (1997) W. Tam, D. Ben-Yehuda e W. S. Hayward. bic and a novel gene activated by proviral insertions in avian leukosis virus-induced lymphomas and is likely to function through its noncoding rna. Moll Cell Biol, 17:1490-14502. Citado na pág. 6

Tanaka et al. (2004) S. Tanaka, Y. Kamachi, A. Tanouchi, H. Hamada, N. Jing e H. Kondoh. Interplay of sox and pou factors in regulation of the nestin gene in neural primordial cells. $\mathrm{Mol}$ Cell Biol, 24:8834-8846. Citado na pág. 106

Taylor et al. (2007) K. H. Taylor, K. E. Pena-Hernandez, J. W. Davis, G. L. Arthur, D. J. Duff, H. Shi, F. B. Rahmatpanah, O. Sjahputera e C. W. Caldwell. Large-scale cpg methylation analysis identifies novel candidate genes and reveals methylation hotspots in acute lymphoblastic leukemia. Cancer Res, 67(6):2617-2625. Citado na pág. 92 
Tennis et al. (2012) M. A. Tennis, M. M. VanScoyk, L. A. Wilson, N. Kelley e W. RA. Methylation of wnt7a is modulated by dnmt1 and cigarette smoke condensate in non-small cell lung cancer. PLoS One, 7(3):e32921. Citado na pág. 97

Tibshirani et al. (2011) R. Tibshirani, G. Chu, B. Narasimhan e J. Li. samr: SAM: Significance Analysis of Microarrays, 2011. R package version 2.0. Citado na pág. 36

Tisi et al. (2013) G. Tisi, F. Salinaro, P. Apostoli, R. Bassani, A. Bellicini, L. Groppi, P. Donarini e S. Pecorelli. Hpv vaccination acceptability in young boys. Ann Ist Super Sanita, 49 (3):286-91. Citado na pág. 19

Tiwari et al. (2008) V. K. Tiwari, L. Cope, K. M. McGarvey, J. E. Ohm e S. B. Baylin. A novel 6c. assay uncovers polycomb-mediated higher order chromatin conformations. Genome Res, 18:1171-1179. Citado na pág. 89

Tong et al. (2010) W. G. Tong, W. G. Wierda, E. Lin, S. Q. Kuang, B. N. Bekele, Z. Estrov, Y. Wei, H. Yang, M. J. Keating e G. Garcia-Manero. Genome-wide dna methylation profiling of chronic lymphocytic leukemia allows identification of epigenetically repressed molecular pathways with clinical impact. Epigenetics, 5(6):499-508. Citado na pág. 106

Tripathi et al. (2013) V. Tripathi, N. C. Popescu e D. B. Zimonjic. Dlc1 induces expression of e-cadherin in prostate cancer cells through rho pathway and suppresses invasion. Oncogene, 33(6):724-733. Citado na pág. 93

Turner et al. (2013) H. C. Turner, I. Baussano e G. P. Garnett. Vaccinating women previously exposed to human papillomavirus: A. cost-effectiveness analysis of the bivalent vaccine. PLoS One, 8(9):e75552. Citado na pág. 19

Vachani et al. (2007) A. Vachani, M. Nebozhyn, S. Singhal, L. Alila, E. Wakeam, R. Muschel, C. A. Powell, P. Gaffney, B. Singh e et al. A 10-gene classifier for distinguishing head and neck squamous cell carcinoma and lung squamous cell carcinoma. Clin Cancer Res, 13:2905. Citado na pág. 105

Vaishlia et al. (2008) N. A. Vaishlia, M. V. Zinoveva, A. V. Sass, E. P. Kopantsev, T. V. Vinogradova e E. D. Sverdlov. Increase of birc5 gene expression in non-small cell lung cancer and esophageal squamous cell carcinoma does not correlate with expression of genes smac/diablo and pml encoding its inhibitors. Mol Biol (Mosk), 42(4):652-661. Citado na pág. 98

van Wieringen et al. (2006) W. N. van Wieringen, J. A. Belien, S. J. Vosse, E. M. Achame e B. Ylstra. Ace-it: a tool for genome-wide integration of gene dosage and rna expression data. Bioinformatics, 22(15):1919-1920. Citado na pág. 8

van Wieringen et al. (2012) W. N. van Wieringen, K. Unger, G. G. Leday, O. Krijgsman, de R. X. Menezes, B. Ylstra e M. A. van de Wiel. Matching of array cgh and gene expression microarray features for the purpose of integrative genomic analyses. BMC Bioinformatics, 13: 80. Citado na pág. 7

Venkataraman et al. (2013) S. Venkataraman, D. K. Birks, I. Balakrishnan, I. Alimova, P. S. Harris, P. R. Patel, M. H. Handler, A. Dubuc, M. D. Taylor e N. K. Foreman. Microrna 218 acts as a tumor suppressor by targeting multiple cancer phenotype-associated genes in medulloblastoma. J. Biol Chem, 288(3):1918-1928. Citado na pág. 6

Verhaak et al. (2010) R. G. W. Verhaak, K. A. Hoadley, E. Purdom, V. Wang, Y. Qi, M. D. Wilkerson, C. R. Miller, L. Ding, T. Golub, J. P. Mesirov e et al. An integrated genomic analysis identifies clinically relevant subtypes of glioblastoma characterized by abnormalities in pdgfra and idh1 and egfr and nf1. Cancer Cell, 17(1):98. Citado na pág. 84 
Verstraelen et al. (2009) S. Verstraelen, I. Nelissen, J. Hooyberghs, H. Witters, G. Schoeters, P. Van Cauwenberge e R. H. Van Den. Gene profiles of a human alveolar epithelial cell line after in vitro exposure to respiratory (non)sensitizing chemicals: Identification of discriminating genetic markers and pathway analysis. Toxicol Lett, 185:16-22. Citado na pág. 89

Villanueva et al. (2012) A. Villanueva, C. Alsinet, K. Yanger, Y. Hoshida, Y. Zong, S. Toffanin, L. Rodriguez-Carunchio, M. Sole, S. Thung, B. Z. Stanger e J. M. Llovet. Notch signaling is activated in human hepatocellular carcinoma and induces tumor formation in mice. Gastroenterology, 143(6):1660-1669. Citado na pág. 107

Vogelstein et al. (2013) B. Vogelstein, N. Papadopoulos, V. E. Velculescu, S. Zhou, L. A. Diaz-Jr e K. W. Kinzler. Cancer genome landscapes. Science, 339:1546. Citado na pág. 1, 81, 99

Voorhoeve et al. (2006) P. M. Voorhoeve, C. le Sage, M. Schrier, A. J. Gillis, H. Stoop, R. Nagel, Y. P. Liu, J. van Duijse, J. Drost e A. Griekspoor. A. genetic screen implicates mir-na-372 and mirna-373 as oncogenes in testicular germ cell tumors. Cell, 124:1169-1181. Citado na pág. 6

Vuillaume et al. (2009) M. L. Vuillaume, N. Uhrhammer, V. Vidal, V. S. Vidal, V. Chabaud, B. Jesson, F. Kwiatkowski e Y. J. Bignon. Use of gene expression profiles of peripheral blood lymphocytes to distinguish brca1 mutation carriers in high-risk breast cancer families. Cancer Inform, 7:41-56. Citado na pág. 89

Wahl et al. (1979) G. M. Wahl, R. A. Padgett e G. R. Stark. Gene amplification causes over production of the first three enzymes of ump synthesis in $\mathrm{n}$ (phosphonacetyl)l aspartateresistant hamster cells. J. Biol Chem, 254:8679-8689. Citado na pág. 5

Wahli e Michalik (2012) W. Wahli e L. Michalik. Ppars at the crossroads of lipid signaling and inflammation. Trends Endocrinol Metab, 23(7):351-363. Citado na pág. 93

Walczak et al. (1997) H. Walczak, M. A. Degli-Esposti e R. S. Johnson. Trail-r 2: a novel apoptosis-mediating receptor for trail. EMBO J., 16:5386-5397. Citado na pág. 94

Walker et al. (2008) E. Walker, A. V. Hernandez e M. W. Kattan. Meta-analysis: Its strengths and limitations. Cleve Clin J. Med, 75(6):431-439. Citado na pág. 90

Wang et al. (2010) D. Wang, C. Qiu, H. Zhang, J. Wang, Q. Cui e Y. Yin. Human microrna oncogenes and tumor suppressors show significantly different biological patterns: From functions to targets. PLoS ONE, 5(9):e13067. Citado na pág. 6

Weber et al. (1998) R. G. Weber, M. Scheer, I. A. Born, S. Joos, J. M. Cobbers, C. Hofele, G. Reifenberger, J. E. Zoller e P. Lichter. Recurrent chromosomal imbalances detected in biopsy material from oral premalignant and malignant lesions by combined tissue microdissection and universal dna amplification and and comparative genomic hybridization. Am J. Pathol, 153 (1):295-303. Citado na pág. 91

Weinberg (1995) R. A. Weinberg. The retinoblastoma protein and cell cycle control. Cell, 81: 323-330. Citado na pág. 103

Wilting et al. (2010) S. M. Wilting, R. A. van Boerdonk, F. E. Henken, C. J. Meijer, B. Diosdado, G. A. Meijer, C. le Sage, R. Agami, P. J. Snijders e R. D. Steenbergen. Methylationmediated silencing and tumour suppressive function of hsa-mir-124 in cervical cancer. Mol Cancer, 9:167. Citado na pág. 104

Wood (2007) L. Wood. The genomic landscapes of human breast and colorectal cancers. Science, 318:1108-1113. Citado na pág. 82 
Worsham et al. (2006) M. J. Worsham, K. M. Chen, V. Meduri, A. O. Nygren, A. Errami, J. P. Schouten e M. S. Benninger. Epigenetic events of disease progression in head and neck squamous cell carcinoma. Arch Otolaryngol Head Neck Surg, 132(6):668-677. Citado na pág. 105

Wrzodek et al. (2013) C. Wrzodek, J. Eichner, F. Buchel e A. Zell. Incromap: integrated analysis of cross-platform microarray and pathway data. Bioinformatics, 29(4):506-508. Citado na pág. 6

Wuchty e Almaas (2005) S. Wuchty e E. Almaas. Peeling the yeast protein network. Proteomics, 5:444-449. Citado na pág. 13

Xia et al. (2000) Y. Xia, N. Papalopulu, P. K. Vogt e J. Li. The oncogenic potential of the high mobility group box protein sox3. Cancer Res, 60(22):6303-6306. Citado na pág. 96

Xie et al. (2013) X. Xie, L. Piao, B. N. Bullock, A. Smith, T. Su, M. Zhang, T. N. Teknos, P. S. Arora e Q. Pan. Targeting hpv16 e6-p300 interaction reactivates p53 and inhibits the tumorigenicity of hpv-positive head and neck squamous cell carcinoma. Oncogene, 33(8):10371046. Citado na pág. 91, 104

Xu et al. (2010) C. Xu, Y. Liu, P. Wang, W. Fan, T. C. Rue, M. P. Upton, J. R. Houck, P. Lohavanichbutr, D. R. Doody, N. D. Futran e et al. Integrative analysis of dna copy number and gene expression in metastatic oral squamous cell carcinoma identifies genes associated with poor survival. Mol Cancer, 9:143. Citado na pág. 82

Xu et al. (2008) L. Xu, E. Hatjiharissi, B. T. Ciccareli, A. M. Roccaro, S. Adamia, A. Sacco, Z. R. Hunter, L. I. Manning, C. J. Patterson e S. P.Treon. Expression of the deleted in liver cancer-1 gene is regulated by dna methylation and is a target for therapy in waldenstrom's macroglobulinemia. Em 2008 ASCO Annual Meeting Proceedings, volume 26 of 15, página 19505, Dana-Farber Cancer Institute and Boston and MA. Dana-Farber Cancer Institute, J. Clin Oncol. Citado na pág. 92

$\mathrm{Xu}$ et al. (2004) X. Xu, L. Wang e D. Ding. Learning module networks from genome-wide location and expression data. FEBS Lett, 578:297-304. Citado na pág. 85

Xue et al. (2013) Y. Z. Xue, T. L. Wu, Y. M. Wu, Y. Y. Sheng, Z. Q. Wei, Y. F. Lu, L. H. $\mathrm{Yu}$, J. P. Li e Z. S. Li. Dlc-1 is a candidate biomarker methylated and down-regulated in pancreatic ductal adenocarcinoma. Tumour Biol, 34(5):2857-2861. Citado na pág. 92

Yamane et al. (2013) K. Yamane, M. Jinnin, T. Etoh, Y. Kobayashi, N. Shimozono, S. Fukushima, S. Masuguchi, K. Maruo, Y. Inoue, T. Ishihara e et al. Down-regulation of mir$124 / 214$ in cutaneous squamous cell carcinoma mediates abnormal cell proliferation via the induction of erk. J. Mol Med (Berl), 91(1):69-81. Citado na pág. 104

Yan et al. (2012) Z. Yan, P. K. Shah, S. B. Amin, M. K. Samur, N. Huang, X. Wang, V. Misra, H. Ji, D. Gabuzda e C. Li. Integrative analysis of gene and mirna expression profiles with transcription factor-mirna feed-forward loops identifies regulators in human cancers. Nucleic Acids Res, 40(17):e135. Citado na pág. 6

Yang et al. (2013) C. Yang, D. Wu, J. Jia, D. Liu, Z. Li, C. Zhang, M. Li e Y. Xia. Dlc1 as a regulator of proliferation and invasion and cell cycle and and apoptosis in cutaneous squamous cell carcinoma. Tumour Biol, 34(5):2633-2643. Citado na pág. 92

Yang et al. (2004) J. Yang, S. A. Mani, J. L. Donaher, S. Ramaswamy, R. A. Itzykson, C. Come, P. Savagner, I. Gitelman, A. Richardson e R. A. Weinberg. Twist and a master regulator of morphogenesis and plays an essential role in tumor metastasis. Cell, 117(7):927-939. Citado na pág. 95 
Yang et al. (2012) Y. Yang, J. Wu, A. Demir, M. Castillo-Martin, R. D. Melamed, G. Zhang, M. Fukunaga-Kanabis, R. Perez-Lorenzo, B. Zheng, D. N. Silvers e et al. Gab2 induces tumor angiogenesis in nras-driven melanoma. Oncogene, 32(31):3627-3637. Citado na pág. 98

Yang e Chang (2013) Y. C. Yang e L. K. Chang. Role of taf4 in transcriptional activation by rta of epstein-barr virus. PLoS One, 8(1):e54075. Citado na pág. 96

Yang e Wang (2011) Z. Yang e L. Wang. Regulation of microrna expression and function by nuclear receptor signaling. Cell $\mathscr{G}$ Bioscience, 1:31. Citado na pág. 95

Yen et al. (2011) C. C. Yen, Y. P. Tsao, P. C. Chen, Y. C. Wu, J. H Liu, C. C Pan, C. Y Liu, C. H Tzeng, P. M Chen, Y. J Chen, C. H Lin e W. H. Hsu. Pml protein as a prognostic molecular marker for patients with esophageal squamous cell carcinomas receiving primary surgery. J. Surg Oncol, 103(8):761-767. Citado na pág. 95

Yin et al. (2012) D. Yin, Y. Jia, Y. Yu, M. V. Brock, J. G. Herman, C. Han, X. Su, Y. Liu e M. Guo. Sox17 methylation inhibits its antagonism of wnt signaling pathway in lung cancer. Discov Med, 14(74):33-40. Citado na pág. 96

Ying et al. (2007) J. Ying, H. Li, P. Murray, Z. Gao, Y. W. Chen, Y. Wang, K. Y. Lee, A. T. Chan, R. F. Ambinder, G. Srivastava e Q. Tao. Tumor-specific methylation of the 8p22 tumor suppressor gene dlc1 is an epigenetic biomarker for hodgkin and nasal nkt-cell and other types of lymphomas. Epigenetics, 2(1):15-21. Citado na pág. 92

Yu et al. (2007) Y. Yu, X. Jiang, B. S. Schoch, R. S. Carroll, P. M. Black e M. D. Johnson. Aberrant splicing of cyclin-dependent kinase-associated protein phosphatase kap increases proliferation and migration in glioblastoma. Cancer Res, 67(1):130-138. Citado na pág. 87

Yunes et al. (2003) M. J. Yunes, A. C. Neuschatz, L. E. Bornstein, S. P. Naber, V. Band e D. E. Wazer. Loss of expression of the putative tumor suppressor nes1 gene in biopsy-proven ductal carcinoma in situ predicts for invasive carcinoma at definitive surgery. Int J. Radiat Oncol Biol Phys, 56:653-657. Citado na pág. 105

Zemach et al. (2010) A. Zemach, I. E. McDaniel, P. Silva e D. Zilberman. Genome-wide evolutionary analysis of eukaryotic dna methylation. Science, 328(5980):916-919. Citado na pág. 5

Zeng et al. (2012) X. Zeng, J. Xiang, M. Wu, W. Xiong, H. Tang, M. Deng, X. Li, Q. Liao, B. Su, Z. Luo e et al. Circulating mir-17 and mir-20a and mir-29c and and mir-223 combined as non-invasive biomarkers in nasopharyngeal carcinoma. PLoS One, 7(10):e46367. Citado na pág. 92

Zhang et al. (2008) W. Zhang, S. C. Glockner, M. Guo, E. O. Machida, D. H. Wang, H. Easwaran, L. Van Neste, J. G. Herman, K. E. Schuebel, D. N. Watkins e et al. Epigenetic inactivation of the canonical wnt antagonist sry-box containing gene 17 in colorectal cancer. Cancer Res, 68(8):2764-2772. Citado na pág. 96

Zhang et al. (2013a) X. Zhang, Y. Dong, H. Ti, J. Zhao, Y. Wang, T. Li e B. Zhang. Downregulation of mir-145 and mir-143 might be associated with dna methyltransferase 3b. overexpression and worse prognosis in endometrioid carcinomas. Hum Pathol, 44(11):2571-2580. Citado na pág. 89

Zhang et al. (2013b) Z. F. Zhang, B. X. Pei, A. L. Wang, L. M. Zhang, B. S. Sun, R. C. Jiang e C. L. Wang. Expressions of cldn1 and insulin-like growth factor 2 are associated with poor prognosis in stage n. 2 non-small cell lung cancer. Chin Med J. (Engl), 126(19):3668-74. Citado na pág. 88 
Zhao et al. (2013a) Q. Zhao, Y. C. Fan, J. Zhao, S. Gao, Z. H. Zhao e K. Wang. Dna methylation patterns of peroxisome proliferator-activated receptor gamma gene associated with liver fibrosis and inflammation in chronic hepatitis b. J. Viral Hepat, 20(6):430-437. Citado na pág. 93

Zhao et al. (2012) W. Zhao, C. C. Huang, G. A. Otterson, M. E. Leon, Y. Tang, K. Shilo e M. A. Villalona. Altered p16(ink4) and rb1 expressions are associated with poor prognosis in patients with nonsmall cell lung cancer. J. Oncol, 2012:957437. Citado na pág. 97

Zhao et al. (2013b) Y. Zhao, Y. Li, L. Wang, H. Yang, Q. Wang, H. Qi, S. Li, P. Zhou, P. Liang, Q. Wang e X. Li. microrna response elements-regulated trail expression shows specific survivalsuppressing activity on bladder cancer. Journal of Experimental \& Clinical Cancer Research, 32:10. Citado na pág. 94

Zhu et al. (2014) C. Zhu, P. Shao, M. Bao, P. Li, H. Zhou, H. Cai, Q. Cao, L. Tao, X. Meng, X. Ju, C. Qin, J. Li e C. Yin. mir-154 inhibits prostate cancer cell proliferation by targeting ccnd2. Urol Oncol, 32(1):31. Citado na pág. 103

Zhu et al. (2010) Q. Y. Zhu, Q. Liu, J. X. Chen, K. Lan e B. X. Ge. Microrna-101 targets mapk phosphatase-1 to regulate the activation of mapks in macrophages. J. Immunol, 185 (12):7435-7442. Citado na pág. 104

Ziech et al. (2011) D. Ziech, R. Franco, A. Pappa e M. I. Panayiotidis. Reactive oxygen species (ros)-induced genetic and epigenetic alterations in human carcinogenesis. Mutat Res, 711(1-2): 167-73. Citado na pág. 93

Zouridis et al. (2012) H. Zouridis, N. Deng, T. Ivanova, Y. Zhu, B. Wong, D. Huang, Y. H. Wu, Y. Wu, I. B. Tan e N. Liem. Methylation subtypes and large-scale epigenetic alterations in gastric cancer. Sci Transl Med, 4(156):156ra140. Citado na pág. 5

zur Hausen (2009) H. zur Hausen. Papillomaviruses in the causation of human cancers - a. brief historical account. Virology, 384:260-265. Citado na pág. 18, 108 


\section{Lista de Abreviaturas}

\begin{tabular}{|c|c|}
\hline aCGH* & Array Comparative Genomic Hybridization \\
\hline $\mathrm{CaPe}$ & Câncer de pênis \\
\hline cDNA* & Complementary deoxiribonucleic acid \\
\hline $\mathrm{CEC}$ & Carcinoma de células escamosas \\
\hline $\mathrm{CGH}^{*}$ & Comparative Genomic Hybridization \\
\hline $\mathrm{CNV}^{*}$ & Copy number variation \\
\hline $\mathrm{CNA}^{*}$ & Copy number alteration \\
\hline $\mathrm{CpG}$ & Citosina-fosfato-Guanina \\
\hline $\mathrm{Cy} 3^{*}$ & Cyanine 3 \\
\hline $\mathrm{Cy} 5 *$ & Cyanine 5 \\
\hline $\mathrm{DGV}^{*}$ & Database of genomic variants \\
\hline DNA* & Deoxiribonucleic acid \\
\hline FDA* & Food and Drug Administration \\
\hline FDR & False Discovery Rate \\
\hline GBM & Glioblastoma Multiforme \\
\hline GEO* & Gene Expression Omnibus \\
\hline GST & Genes Supressores Tumorais \\
\hline $\mathrm{HCL}^{*}$ & Hierarchical clustering \\
\hline $\mathrm{HPV}^{*}$ & Human papillomavirus \\
\hline RNAi & RNA de interferência \\
\hline $\mathrm{LOH}^{*}$ & Loss of heterozygosity \\
\hline miRNA* & Micro $R N A$ \\
\hline MMP* & Matrix metalloproteinase \\
\hline $\mathrm{NA}^{*}$ & Not available \\
\hline nd & não disponível \\
\hline $\mathrm{ORF}^{*}$ & Open reading frame \\
\hline PCA & Principal Component Analysis \\
\hline $\mathrm{PCR}^{*}$ & Polymerase chain reaction \\
\hline $\mathrm{PeCa}^{*}$ & Penile Carcinoma \\
\hline PPI* & Protein-Protein Interaction \\
\hline RT-qPCR* & Quantitative reverse transcriptase polymerase chain reaction \\
\hline siRNA* & Small interfering $R N A$ \\
\hline RNA* & Ribonucleic acid \\
\hline ROS* & Reative oxygen species \\
\hline $\mathrm{SF}$ & Sítios frágeis \\
\hline TCGA* & The Cancer Genome Atlas \\
\hline TNM & Estadio clínico \\
\hline UCSC* & University of California, Santa Cruz \\
\hline UNG* & AmpErase uracil-N-glicosilase \\
\hline $\mathrm{URR}^{*}$ & Upstream regulatory region \\
\hline VLP* & Virus like particles \\
\hline $\mathrm{NCI}^{*}$ & National Cancer Institute \\
\hline G & Ganho de sequência de DNA \\
\hline $\mathrm{P}$ & Perda de sequência de DNA \\
\hline EA & Expressão aumentada \\
\hline ED & Expressão diminuída \\
\hline TS* & Tumor Suppressor \\
\hline $\mathrm{ON}$ & Oncogene \\
\hline PQ & Proteina quinase \\
\hline $\mathrm{EC}$ & Estabilidade celular \\
\hline $\mathrm{HE}$ & Hipermetilaçẫo \\
\hline
\end{tabular}


$\mathrm{HO}$

EM

mRNA

CBS

GLAD

GO

GWAS

$\mathrm{NIH}$

CPD

MRE
Hipometilação

ExpectationâĂŞMaximization

RNA mensageiro

Circular Binary Segmentation

Gain and Loss Analysis of DNA

Gene Ontology

Genome-Wide Association Study National Institute of Health

Conditional Probability Distribution

miRNA response elements

* siglas ou abreviaturas derivadas do inglês 


\section{Lista de Símbolos}

\begin{tabular}{|c|c|}
\hline$X_{g}$ & Variável aleatória para g genes \\
\hline$z$ & Módulo \\
\hline$M$ & Matriz de dados \\
\hline$N$ & Número de genes \\
\hline$m$ & Número de amostras \\
\hline$M_{z}$ & Conjunto de módulos \\
\hline$A_{z} \subset 1, \ldots, N$ & Conjunto de módulos contento $1, \ldots, N$ genes \\
\hline$p(x \mid \mu, \varphi)$ & Distribuiçãa normal \\
\hline$\mu$ & Média \\
\hline$\gamma$ & Valor para divisão do módulo em duas partes \\
\hline$\varphi$ & Precisão \\
\hline$R$ & Conjunto de reguladores \\
\hline$R_{z}$ & Número de reguladores no módulo $z$ \\
\hline$\theta$ & Nó da árvore de regressão \\
\hline$r_{\theta}$ & Regulador de um dado nó da arvore \\
\hline$\theta$ & Para um dado nó da arvore $(\theta)$ o valor de divisão $\gamma$ \\
\hline$y_{\theta}$ & Variável binaria da arvore de decisão $(1,-1)$ definem a direção da divisão do módulo \\
\hline$x_{r}$ & Expressão de um determinado regulador \\
\hline$\theta$ & Peso de um nó da árvore de regressão \\
\hline$E$ & Estrutura \\
\hline$m x n$ & Matriz com $m$ genes e $n$ amostras \\
\hline$r$ & Expressão de um gene regulador \\
\hline$M_{e x}$ & Matriz de expressão de transcritos codificadores \\
\hline$M_{\text {cna }}$ & Matriz de alteração do número de cópias \\
\hline$M_{m e}$ & Matriz de metilação do DNA \\
\hline$M_{m i}$ & Matriz de expressão de miRNAs \\
\hline$V$ & Vértice \\
\hline$P$ & Probabilidade \\
\hline
\end{tabular}

